\title{
EXPLORING OPPORTUNITIES FOR ON-FARM INNOVATIONS IN SMALLHOLDER DAIRY SYSTEMS OF MICHOACÁN, MEXICO
}

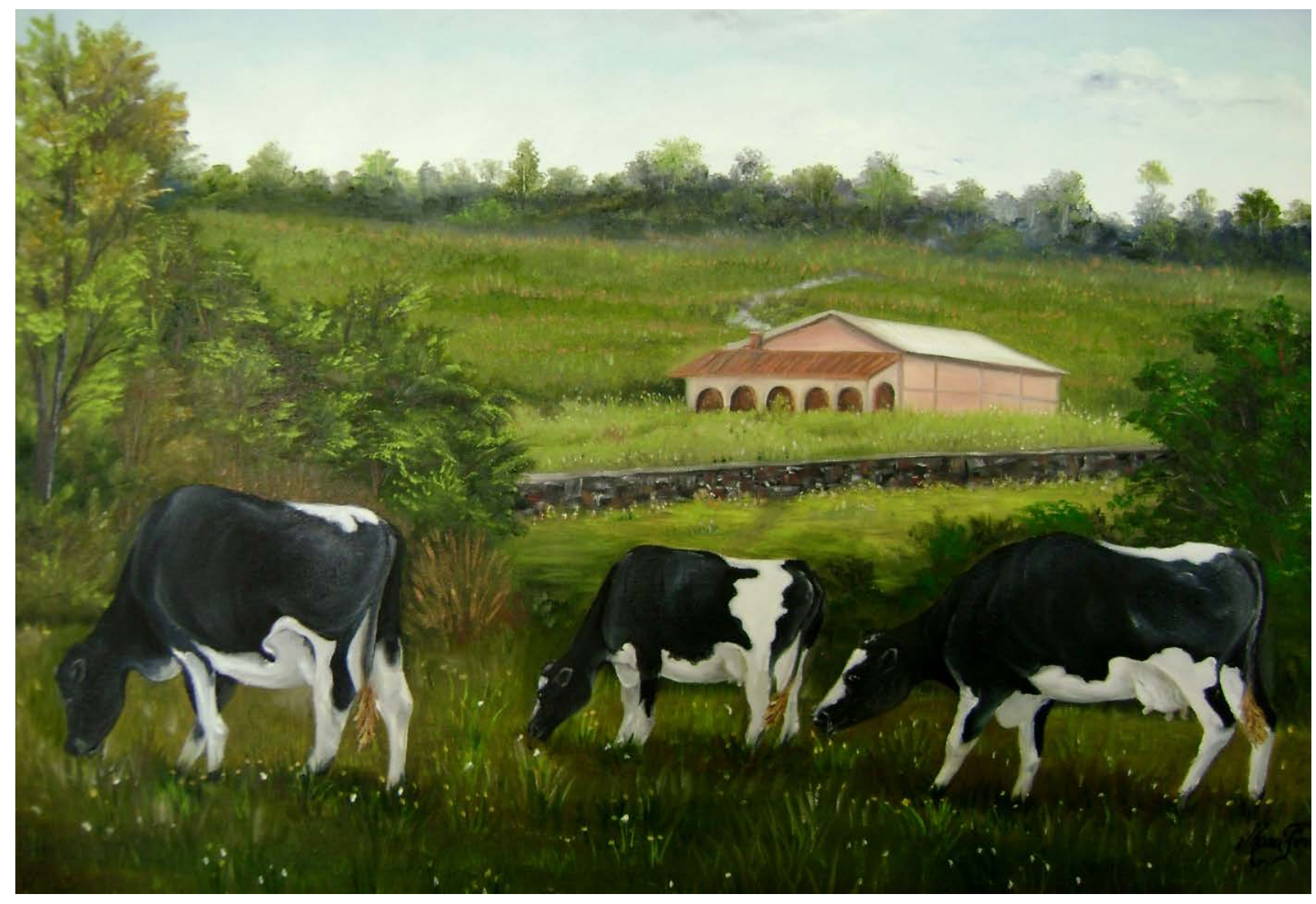

JosÉ CORTEZ ARRIOLA 
Exploring opportunities for on-farm innovations in smallholder dairy systems of Michoacán, Mexico

José Cortez Arriola 


\section{Thesis committee}

\section{Promotor}

Prof. Dr P.A. Tittonell

Professor of Farming Systems Ecology

Wageningen University

\section{Co-promotors}

Dr W.A.H. Rossing

Associate professor, Farming Systems Ecology

Wageningen University

Dr R.D. Améndola Massiotti

Graduate Program in Animal Science

Chapingo University, Mexico

Dr J.C.J. Groot

Associate professor, Farming Systems Ecology

Wageningen University

\section{Other members}

Dr S.J. Oosting, Wageningen University

Prof. Dr P.C. Struik, Wageningen University

Dr G.W.J. van de Ven, Wageningen University

Dr B. Gérard, CIMMYT, Texcoco, Mexico

This research was conducted under the auspices of the C.T. de Wit Graduate School of Production Ecology and Resource Conservation. 


\title{
Exploring opportunities for on-farm innovations in smallholder dairy systems of Michoacán, Mexico
}

\author{
José Cortez Arriola
}

Thesis

submitted in fulfilment of the requirements for the degree of doctor

at Wageningen University

by the authority of the Rector Magnificus

Prof. Dr A.P.J. Mol,

in the presence of the

Thesis Committee appointed by the Academic Board

to be defended in public

on 6 July 2016

at 8.30 in the Aula. 
José Cortez Arriola

Exploring opportunities for on-farm innovations in smallholder dairy systems of Michoacán, Mexico, 162 pages.

PhD thesis, Wageningen University, Wageningen, NL (2016)

With references, with summary in English

ISBN 978-94-6257-747-3

DOI $10.18174 / 374928$ 


\section{Table of contents}

Chapter 1: General Introduction.

Chapter 2: $\quad$ Leverages for on-farm innovation from farm typologies? An illustration for family-based dairy farms in north-west Michoacán, Mexico.

Chapter 3: $\quad$ Resource use efficiency and farm productivity gaps of smallholder dairy farming in North-west Michoacán, Mexico

Chapter 4: Alternative options for the sustainable intensification of smallholder dairy farms in North-West Michoacán, Mexico.....

Chapter 5: Capturing agro-ecosystem vulnerability and resilience.

Chapter 6: General discussion

Summary.

Acknowledgment.

159

Curriculum vitae. 160

PE\&RC Training and Education Statement. 



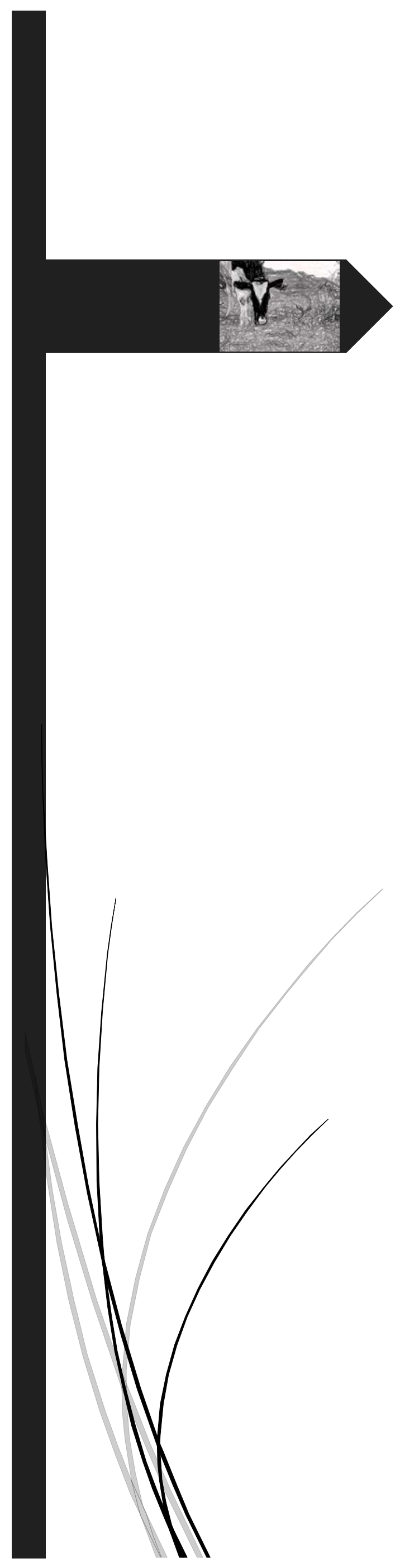

Chapter 1: General introduction 



\subsection{Background and introduction of the problem}

At a global level, the main drivers stimulating livestock production are economic growth and increases in population and income, changes in life style and consumption patterns, international trade and globalization of markets, globalization and privatization of agricultural science, and technological innovations (Steinfeld et al., 2006a; Herrero et al., 2010; Herrero et al., 2012; Alexander et al., 2015). An expected global population growth of $36 \%$ along with changes in life style and consumption patterns in countries such as China, India and Brazil are projected to have a significant impact on agricultural production systems during the first three decades of the $21^{\text {st }}$ Century (FAO, 2012). Moreover, $60 \%$ of the global population will live in urban areas by 2030, while in 2000 this number was only 47\% (UN, 2006). Annual food consumption per capita is expected to increase by 9\%, whereas at the same time, pronounced changes in the diet are expected to occur. While the share of cereals, roots, tubers and dry pulses have been declining (Alexander et al., 2015), the meat and milk consumption is projected to continue increasing (Steinfeld et al., 2006b, Alexandratos and Bruinsma, 2012; Alexander et al., 2015).

There are three possible solutions to meet this projected increase in food demand. The first solution is to reduce food losses and waste, which currently causes around one-third of the edible food products to be lost or wasted (Gustavsson, 2011). This is the solution with the least social, economic and environmental impacts. It involves reducing losses during agricultural production, postharvest handling and storage, processing, distribution and subsequent consumption. The second solution is to increase the area dedicated to livestock production and arable farming. Considering 3.2 billion ha at world level, currently remain 1.4 billion ha available for growing; however, there are some considerations and constrains that challenge their use, such as: their distribution among regions and countries, land suitability, environmental aspects, incidence of weeds and diseases, and lack of infrastructure (Alexandratos and Bruinsma, 2012). The third solution is to improve farm systems resource use efficiencies and thereby also productivity, this in order to produce "more" with "less" (Herrero et al., 2009; Steinfeld and Gerber, 2010). In this context, research can play an important role in system design and developing new and more efficient technologies to produce food that continue to feed a global population without compromising inherent production capacity or natural resources.

Climatic and physiographic conditions, demand as related to consumption patterns and population growth, prices as affected by market demand and imports, and production costs are the key drivers that determine milk production in Mexico. However, variation in drivers occurs and this has generated a diversity of dairy farming systems. Problems common to most dairy systems are: a) (over)exploitation of natural resources, including aquifers, soil and grazing lands; b) negative environmental impacts such as soil erosion and degradation, water pollution, and greenhouse gas emission; c) high dependency on external inputs and exogenous technology; d) lack of organization among farmers, 
which reduces the ability to be competitive in local markets, and e) increased globalization and unfair competition due to subsidized production which hampers farmers to be competitive in global markets (Velázquez et al., 2002; Lara-Covarrubias et al., 2003; Sotelo et al., 2005; Aguilar and López, 2006; CONAGUA, 2011; Pinos-Rodriguez et al., 2012; SE, 2012).

Dairy farmers who realized the importance of "economies of scales" in terms of reducing production cost and increasing bargaining power formed cooperatives and/or pursued horizontal and vertical integration. In this manner they aim to more effectively compete with international prices and to increase profit margins (Lara-Covarrubias et al., 2003). In some cases, they became specialized farmers, which currently still represent only $17 \%$ of the dairy farms at the national level. The remaining $83 \%$ of dairy farmers are being classified as "small” (family-based), "medium” (semispecialized), or double-purpose farmers. These three groups have not been able to find a way to be competitive in the national and international markets of dairy products (SAGARPA, 2000; LaraCovarrubias et al., 2003; SAGARPA, 2011). For this reason, many farmers are being forced to diversify their operations or stop farming and seek employment elsewhere (Cervantes and Cesín, 2007). With unemployment rates increasing from $2.2 \%$ to $5.6 \%$ and with $31 \%$ of the Mexican economically active population working in the informal economy during the last decade (INEGI, 2012; OECD, 2013), sources of employment are scarce and salaries thus are low. This forces family members of farmers to migrate to other states or, in most of the cases, to other countries to look for alternative employment. However, due to the global economic decline and more strict migration policies, the international migration rate has dropped from $14 \%$ to $5 \%$ over the last decade (INEGI, 2013). As a consequence, the flow of remittances diminished by $10.8 \%$, and the amount of foreign exchange by $15.5 \%$ (Reyes, 2008; Cervantes, 2012), which negatively impacts family incomes and local investment capacity.

For decades, the Mexican government has implemented programs to support farmers in their agricultural activities and to allow them to retain their rural livelihoods. Over time these programs changed from policies of price control, price support, and subsidies on inputs and insurance (OECD, 2006) to cash support. Currently, PROCAMPO and PROGAN are the main governmental programs to support agricultural activities with national coverage (SAGARPA, 2010a, b). Even though these programs were created by the government to support smallholder farmers to improve their production systems, to stimulate farmer organization, and to stop environmental degradation, with limited financial resources, the biggest and more intensive farmers have also been benefited. These programs have been positively assessed by the government in terms of the area and number of farmers supported, but their technical, social, environmental and economical goals have not been achieved (Schwentesius et al., 2007; SAGARPA, 2010a; Zarazúa-Escobar et al., 2011).

Considering that dairy products are part of the basic food basket and Mexico is the world's largest importer of powder milk and milk formulas which is undermining policy aimed at achieving national 
food sovereignty (initiative of the "Ley de planeación para la soberanía y la seguridad agroalimentaria y nutricional”), improving productivity and efficiency of dairy systems is of key importance. Therefore, strengthening of national production capacity and efficiency to meet the national demand and to more effectively compete on international market should be integral part of national policy. However, implementation of such policy requires socio-technological innovations that foster growth of the national dairy industry that is technically feasible, socially responsible, economically viable and environmentally acceptable. To reach this goal and considering the domains involved, a systems approach is needed that addresses the production and management systems at farm level and the institutional settings from a regional to the national level.

\subsection{Characterization of the study region}

\subsubsection{Historical context of livestock production}

The study region comprises the municipality of Marcos Castellanos, Michoacán State, Mexico. Livestock production, particularly cattle and sheep in this region, is dating back to 1545 (González, 1995). Traditionally, animals were held in extensive grazing systems based on native species. Around 1850 production systems became more intensive (González, 1995), with stocking rates being supported by deforestation to improve forage production and by dividing rangeland into paddocks. Different types of cheese, wool, purified bee wax, and mezcal (an alcoholic beverage) were the main products produced and commercialized in the region (González, 1995). However, dairy production is the only production system that remained economically viable and evolved to one of the main economic activities in the study region.

\subsubsection{Brief description of the study region}

\section{Geography and land use}

Marcos Castellanos is located in the North-west of Michoacán state at $19^{\circ}$ northern latitude and $103^{\circ}$ western longitude, at altitudes between 1,500 and 2,400 masl (Figure 1.1). Based on the classification of Mexican hydrological regions, Marcos Castellanos is located in the upper part of the "Lerma Chapala" basin, in the sub-basin "Chapala", and in the micro-basin "San José de Gracia" (SEMARNAT, 2003). The total area of the municipality is 23,128 ha, representing $0.39 \%$ of the State. The main land use types are cropland (12.5\%) and grazing land (rangeland) (86.6\%) mostly comprised of native plant species (Secretaría de Gobierno, 2010). 


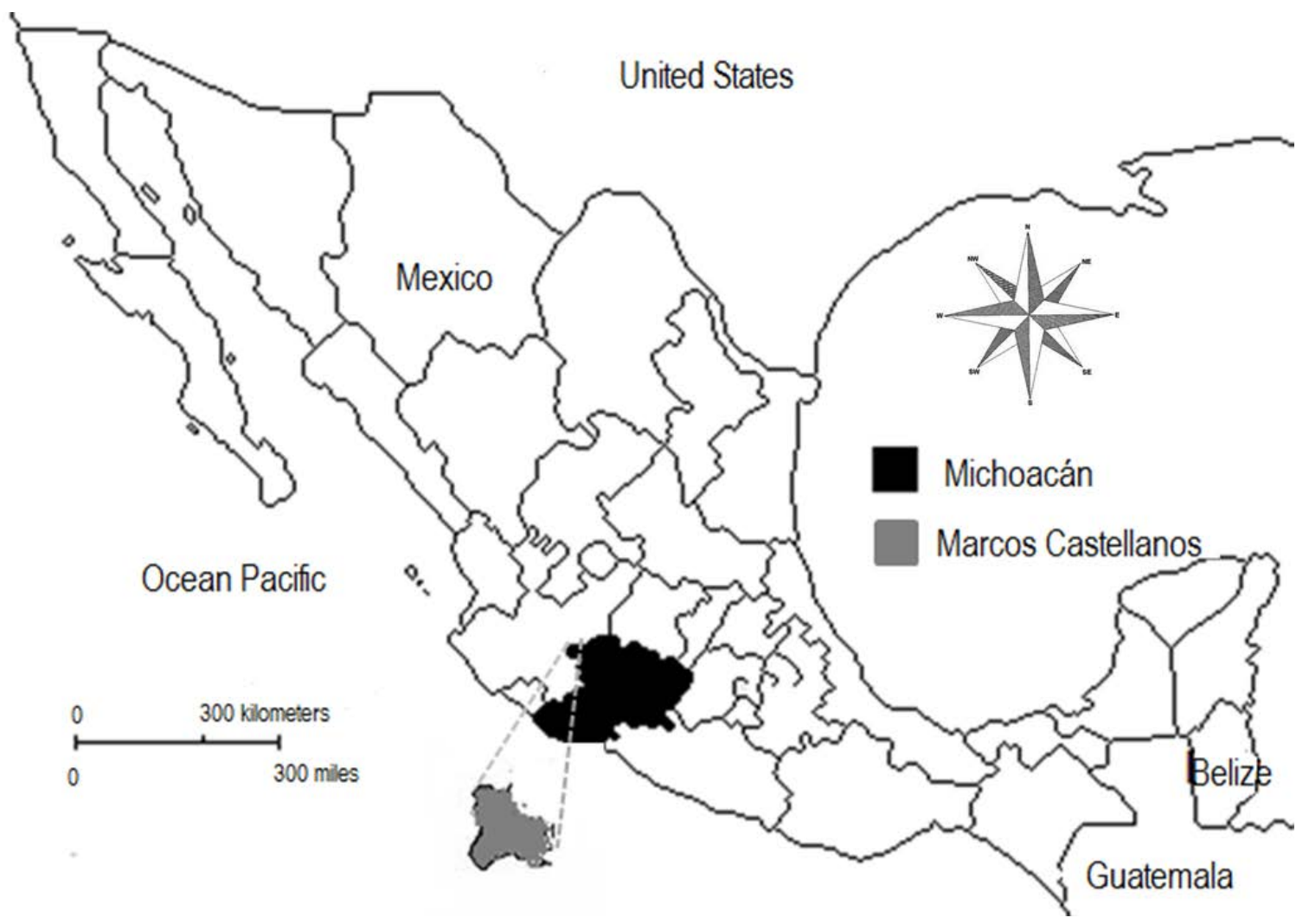

Figure 1.1. Location of Marcos Castellanos, Michoacán State, Mexico.

\section{Climate}

The climate of the municipality is classified as temperate. December and January are the coldest months with average temperatures of $16^{\circ} \mathrm{C}$ while May is the hottest month with average values of $22^{\circ} \mathrm{C}$. The average annual rainfall is $790 \mathrm{~mm}$, with $83 \%$ being concentrated in the period from June to October. This rainfall distribution is the main constraint for year-round forage and crop production, and also limits overall productivity. Irrigation using groundwater sources is limited to wells established prior to 1987. After this year, a negative balance of the "Ciénega de Chapala” aquifer prompted a ban on drilling new wells for agriculture, livestock, and industry (CONAGUA, 2002; Romero et al., 2001).

\section{$\underline{\text { Soils }}$}

Vertisols constitute the predominant soil type, with subunits being chromic and pellic. They occur in association with Luvisols, featuring either vertic and chromic subunits along with Phaeozem and Andosols (SEMARNAT, 2003). In the study region, Vertisols form deep and relatively uniform profiles and soils are slightly acidic, with a low salinity, on average low to medium organic matter content, high bulk density along with a medium cation exchange capacity and base saturation (Table 1.1). Moreover, its consistency is mostly extremely hard when dry, plastic and sticky when wet, and 
its permeability is low. Unfavorable soil characteristics in terms of organic matter content, bulk density, consistency and permeability are typical of soils that have been overgrazed or under an intensive mechanization (Taddese et al., 2002; Bravo-Garza and Bryan, 2005).

\section{Population}

In 2010 the population of the municipality of Marcos Castellanos amounted to about 13,000 inhabitants which translate to 15\% of the population of the state of Michoacán (INEGI, 2010). In Marcos Castellanos, 55\% of the population is classified as living in poverty, with $23 \%$ facing food shortage which is $5 \%$ higher than the national average (SEDESOL, 2013). The economically active population comprises about 5,100 inhabitants (INEGI, 2010) of which 26\% work in the primary sector, and 24\% are employed in industry (SEDESOL, 2013), mostly dairy factories. Traditionally, the population of Michoacán migrated to other states in Mexico or to United States. In the US they constitute $11 \%$ of the Mexican migrants and represent the second largest group of Mexicans (Albo and Ordaz, 2011). Across Michoacán remittances account for $10 \%$ of the gross domestic product, the largest percentage of all states, and in size similar to the contribution of the primary sector (Albo and Ordaz, 2011). In Marcos Castellanos, 9\% of the population migrated, mainly to United States (INEGI, 2010), and according to Albo and Ordaz (2011) remittances in rural areas represent between $27 \%$ and $40 \%$ of family income.

\section{Animal production}

Rearing beef cattle and pigs represent the largest economic contribution to the livestock production sector in Michoacán (53\% and 25\% of the total value) while the dairy sector constitutes 18\% (Figure 1.2). However, in Marcos Castellanos, the dairy sector represents 59\% of the economic production value, followed by beef cattle with $37 \%$.

Table 1.1. Physical and chemical characteristics of the topsoil layer $(0-30 \mathrm{~cm})$ for sampled Vertisols in Marcos Castellanos, Michoacán, Mexico. ${ }^{1}$

\begin{tabular}{|c|c|c|c|c|c|c|c|c|c|}
\hline & \multirow{2}{*}{$\mathrm{pH}$} & \multirow{2}{*}{$\begin{array}{c}\mathrm{BD}^{2} \\
\left(\mathrm{~g} \mathrm{~cm}^{-3}\right)\end{array}$} & \multirow{2}{*}{$\begin{array}{c}\mathrm{EC}^{2} \\
\left(\mathrm{Mmhos} \mathrm{cm}^{-1}\right)\end{array}$} & \multirow{2}{*}{$\begin{array}{l}\mathrm{OM}^{2} \\
(\%)\end{array}$} & \multirow{2}{*}{$\begin{array}{c}\mathrm{CEC}^{2} \\
\left.\text { (me } 100 \mathrm{~g}^{-1}\right)\end{array}$} & \multirow{2}{*}{$\begin{array}{l}\text { BS } \\
(\%)\end{array}$} & \multicolumn{3}{|c|}{ Texture (\%) } \\
\hline & & & & & & & Sand & Clay & Silt \\
\hline Minimum & 5.2 & 1.66 & 115.2 & 1.62 & 22.2 & 42.9 & 23.5 & 39.5 & 9.0 \\
\hline Average & 5.9 & 1.76 & 191.2 & 3.01 & 30.5 & 54.2 & 30.5 & 47.0 & 22.5 \\
\hline Maximum & 6.5 & 1.88 & 276.0 & 4.41 & 32.0 & 62.6 & 37.5 & 55.5 & 33.0 \\
\hline
\end{tabular}

\footnotetext{
${ }^{1}$ Values are averages obtained in 8 plots under three different land use types (cropland, rangeland and improved pasture), in two localities of Marcos Castellanos, at the end of the dry season of 2009.

${ }^{2} \mathrm{BD}=$ Bulk density; EC = Electrical conductivity; OM = Organic matter; CEC = Cation exchange capacity, and BS = Base saturation .
} 


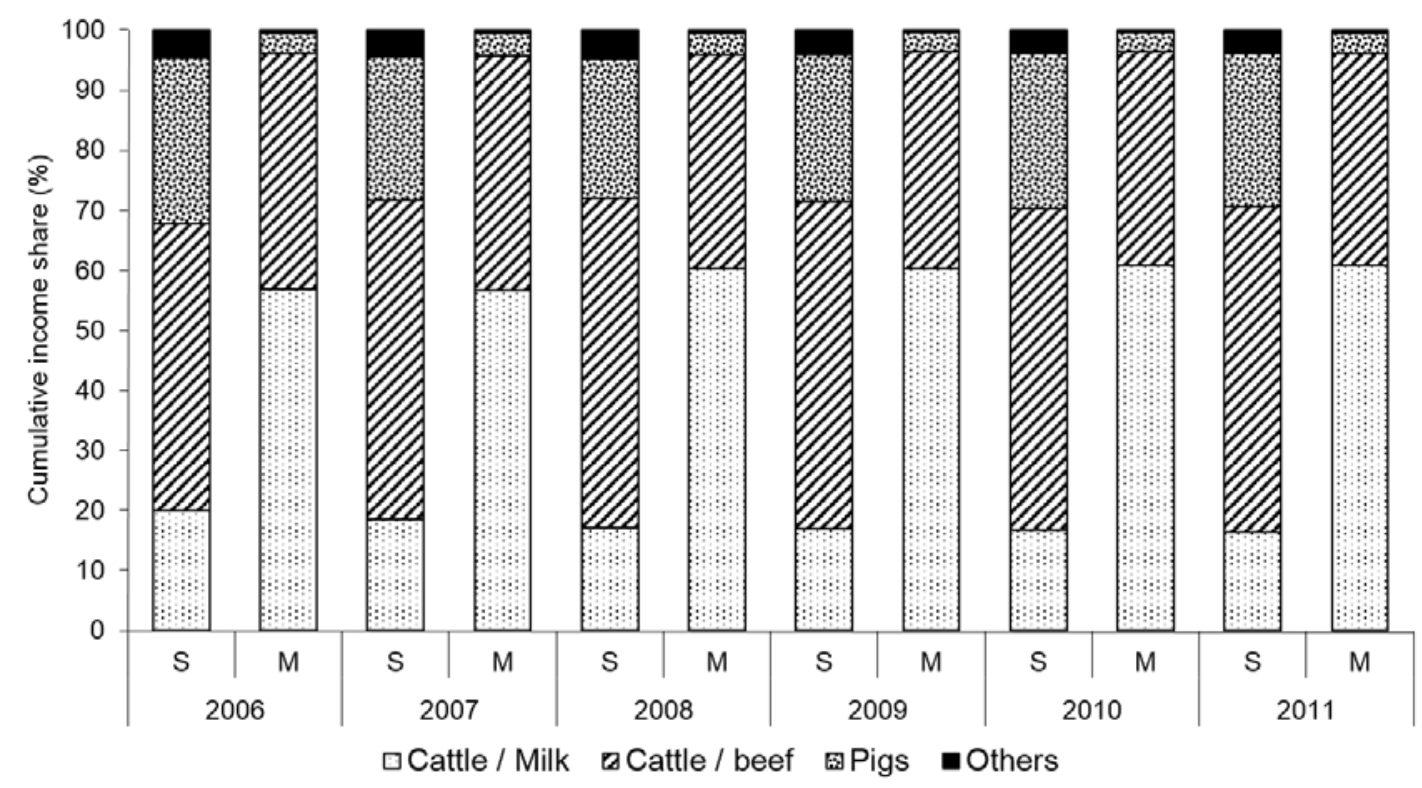

Figure 1.2. Share of livestock production (\%) in the state (S) and municipal (M) income. Source: www.siap.gob.mx/index.php?option=com_wrapper\&view=wrapper\&Itemid=373 (Own elaboration).

\section{Dairy production}

During the last two decades, Michoacán had an average annual growth of milk production of $1.7 \%$, but its share at the national level dropped from 3.7\% to 3.1\% (Figure 1.3). Only $40 \%$ of the milk required for the state population was produced inside the state (estimation based on INEGI, 2010, and SAGARPA, 2011). Among the 113 municipalities within Michoacán, Marcos Castellanos produced most milk, representing $11 \%$ of the overall milk production.

\subsubsection{Dairy farms in Marcos Castellanos}

Based on a random sample of $15 \%$ of the farms in 2007, the average farm size in the municipality was 59 ha, with a range from 2.5 ha to 240 ha. About $28 \%$ of the farmers were the owners of the entire farmed area while $20 \%$ did not own any land. The remaining 52\% farmers rented on average $71 \%$ of the land they farmed. Routinely, the contract for renting land lasts one year with the possibility of renewal or cancellation before the stipulated period. Due to this uncertainty in land tenure, there is little or no incentive for farmers to invest in improvements, and they typically just use the land as-is and focus on short-term returns. This hampers investments in soil fertility maintenance or increase, pasture productivity, local infrastructure, the access to loans, and typically results in degradation of soils and low pasture productivity. 


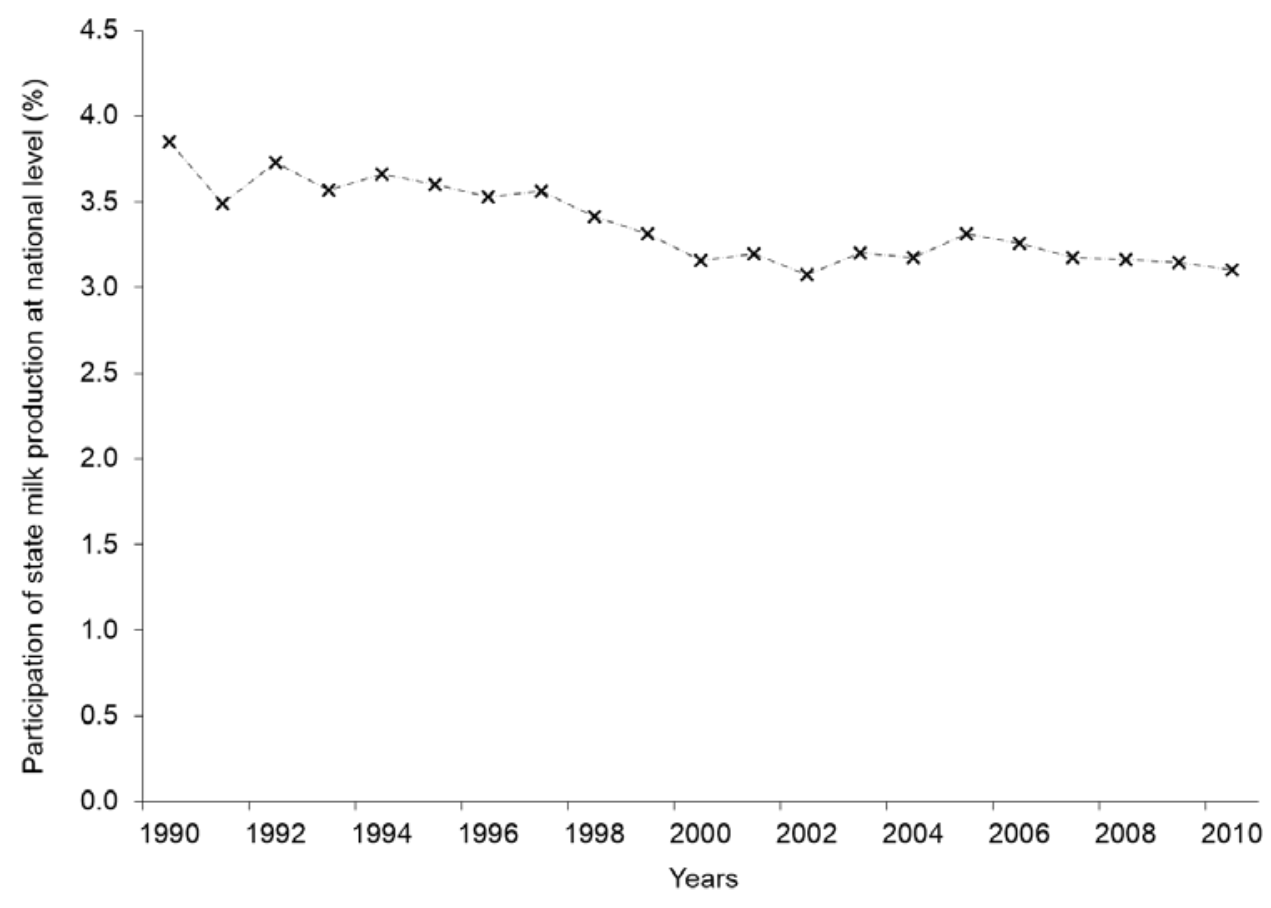

Figure 1.3. Share of national milk production (\%) by Michoacán between 1990 and 2010. Source: SAGARPA (2011).

Holstein Friesian is the main breed used for dairy farmers in the municipality, and the cows of this breed are in some cases crossed with Zebu, Brown Swiss, and Jersey (Sánchez and Sánchez, 2005). Natural mating by bulls is common practice. Artificial insemination is used by some farmers, handled by themselves or by specialists.

The rangeland is the main source of forage during the rainy season. It is complemented with maize "stover" ("rastrojo" is the local name for this dry milled whole maize plants, including cobs) and purchased concentrates of variable quality. During the dry season conserved forages and concentrates become the main feedstuffs of cows due to the lack of forage production in the grazing lands (Reséndiz, 1986; Sánchez and Sánchez, 2005). Cows in lactation receive between 4 and 8 kg DM d ${ }^{-1}$ from a mixture of ground maize stover and concentrates supplied to animals during the milking. Drinking water for animals is obtained from small reservoirs built to capture run-off during the rainy season and from fresh drinking water distributed by the government for human consumption.

During the lactation period, cows are milked twice a day. Milking is mainly done by hand and only few farmers own small milking parlors. As a result, milking constitutes a major part of the labor demand. The average milk production is $3660 \mathrm{~L} \mathrm{cow}^{-1}$ lactation $^{-1}$ which translates to $12 \mathrm{~L} \mathrm{cow}^{-1}$ day $^{-1}$ based on a lactation period of 305 days. Milk is typically sold as raw milk to middlemen, small local industries or Liconsa, the governmental agency (Sánchez and Sánchez, 2005). Cheese, cream and yogurt are the main processed products produced in the region, and these are commercialized in cities close to the municipality, including Mexico City. 


\subsection{Sustainability of smallholder dairy systems}

Various research projects have addressed the economic, social, and technological performance of smallholder dairy farming systems (family-based and semi-specialized), and the policies that impact at the farm level. Arriaga-Jordán et al. (2002), Cervantes and Cesín (2007), Espinosa et al. (2007), Espinosa et al. (2008), Espinoza-Ortega et al. (2005), Sánchez et al. (2008) and Colunga et al. (2009) analyzed the economic performance of smallholder dairy farmers in Central Mexico. Overall, these systems were characterized by negative net margins (when all costs were included) or small gross margin (when only cash costs were considered), and the family income was complemented with external earnings which represented $28 \%$ and $54 \%$ in rural and urban areas, respectively (Cervantes and Cesín, 2007). Espinosa et al. (2002) and Espinosa et al. (2008) found that farmers receive between $52 \%$ and $68 \%$ of the raw milk price paid by the consumers when commercialized directly by middlemen, and $41 \%$ of the pasteurized milk price in the market. These amounts only represent the share received for farmers without including the analysis of milk production costs. However, according to Sánchez et al. (2008), the high external dependency on feedstuffs and the milk price paid to farmers were the main limiting factors in these systems to increase profit. Normally feed costs represent the highest share of milk production costs in smallholder farmers; Lara-Covarrubias et al. (2003) found these to be $62 \%$ and $72 \%$ of the milk production costs in the semi-specialized and family-based smallholder dairy systems, respectively, while Espinoza-Ortega et al. (2005) found feed costs to represent between $46 \%$ and $57 \%$ and between $53 \%$ and $77 \%$ of the total production costs, respectively. Similar values were found by Arriaga-Jordán et al. (2002) for smallholders in Central Mexico when analyzing feeding strategies based on grazing systems.

Little work has been done to explore alternatives to support smallholder dairy farmers in decision making and to improve farm's performance. The work already done has focused on exploring alternatives to improve mostly economic and social domains. Castelán-Ortega et al. (2003a,b) developed a bio-economic linear optimization model to combine resources and technologies to evaluate economic and social aspects of sustainability. On the other hand, Val-Arreola et al. (2004) used linear programming and partial budgeting techniques to explore options to optimize land use for forage production, nutrient availability and to assess their economic impact in representative smallholder dairy farms of Michoacán State. Val-Arreola et al. (2006) using goal programming and compromise programming tested a single optimal solution vs. a set of plausible alternatives to maximize use of nutrient for milk production and incomes, and to minimize purchased feedstuffs, optimizing individually each one. These studies paid little attention to the environmental domain as part of the model, their level of specificity prevent their use for integrative analysis of the systems, and the use of linear programming techniques restrict the space of possible (even sub-optimal) options that may be available to farmers. 


\subsection{Objectives}

The overall aim of this thesis is to assess the environmental, social and economic performance of smallholder dairy farming in Marcos Castellanos, Michoacán, Mexico, and to use this assessment to explore alternatives to enhance farm sustainability. In this manner the thesis aims to support decision making by farmers and technicians and to provide information that can aid local governments to establish policies that are effective at improving farmers’ livelihoods.

The specific objectives are to:

- Identify to what extent the results of farm surveys that measure primarily scale of production can inform on-farm interventions aimed at improving farm performance;

- Analyze how management strategies for different dairy farming systems affect nutrient and soil organic matter balances, nutrient use efficiency, economic efficiency and labor productivity;

- Explore management alternatives that can enhance dairy farming systems performance, while improving resource use efficiency and reducing negative environmental impacts; and

- Analyze vulnerability and resilience of these dairy farming systems in the context of disturbances in the availability of internal and external inputs.

\subsection{Methodological approach}

This study focuses on sustainable intensification of smallholder dairy farms by analyzing the current situation and exploring the window of opportunity for improvement. Current farm performance will be evaluated using a systems approach where the soil-crop-animal-manure and the socio-economic subsystems on-farm and their interactions were considered. Work included a survey in the study region to gather information on the population of dairy farms, development of a farm typology, selection of 'typical' farms, monitoring of these pilot farms, field experiments and measurements, and modeling. Together these methodological steps followed the "DEED” (Describe, Explain, Explore and Design) farming systems analysis approach (Figure 1.4) (Tittonell, 2008).

The description of the current farming systems started with a survey, in which $14.6 \%$ of all dairy farms registered in the census of the regional dairy association were interviewed. An interdisciplinary team of scientists visited the sample farms and gathered information based on a questionnaire. The survey questionnaire included questions related to biophysical components, socio-economic performance, physical resources, and farm management. The information collected was then used to develop a farm typology and to analyze if and which extent results can inform on-farm interventions to improve farm performance. The selection of the pilot farms was based on their representativeness for a type of dairy system and on the willingness of the farmers to share data on their performance with 
other farmers. These pilot farms were intensively monitored for at least one year to be able to explain in more detail their performance and to find causes of diversity. Models were used as tools to understand the current situation and to explore alternatives. In order to characterize each individual farm, information related to farm management and agro-environmental parameters was gathered between July 2008 and June 2010. The information collected during the first year was used to adapt the methodologies, to parameterize the models, and to identify the parameterization and validation of the variables that needed to be measured. The information of the second year was used to explain the functioning of current farming systems. At the crop subsystem level, information was collected on forage production, quality, utilization, inputs, and production costs. At the animal subsystem level, data were obtained pertaining to herd structure, milk production and composition, animal body weight and condition score, quality and intake of feedstuffs, and sanitary and reproductive management. The agro-environmental variables included soil sampling and runoff measurements during the rainy season, determining soil physical and chemical properties and soil losses in grazing and cropping lands. Half-yearly project meetings, technical courses, and the two-weekly farm visits helped to create a good relation between participating farmers and local researchers. The interactions enabled the researchers to have an open dialogue in a natural setting and to obtain detailed information on farm

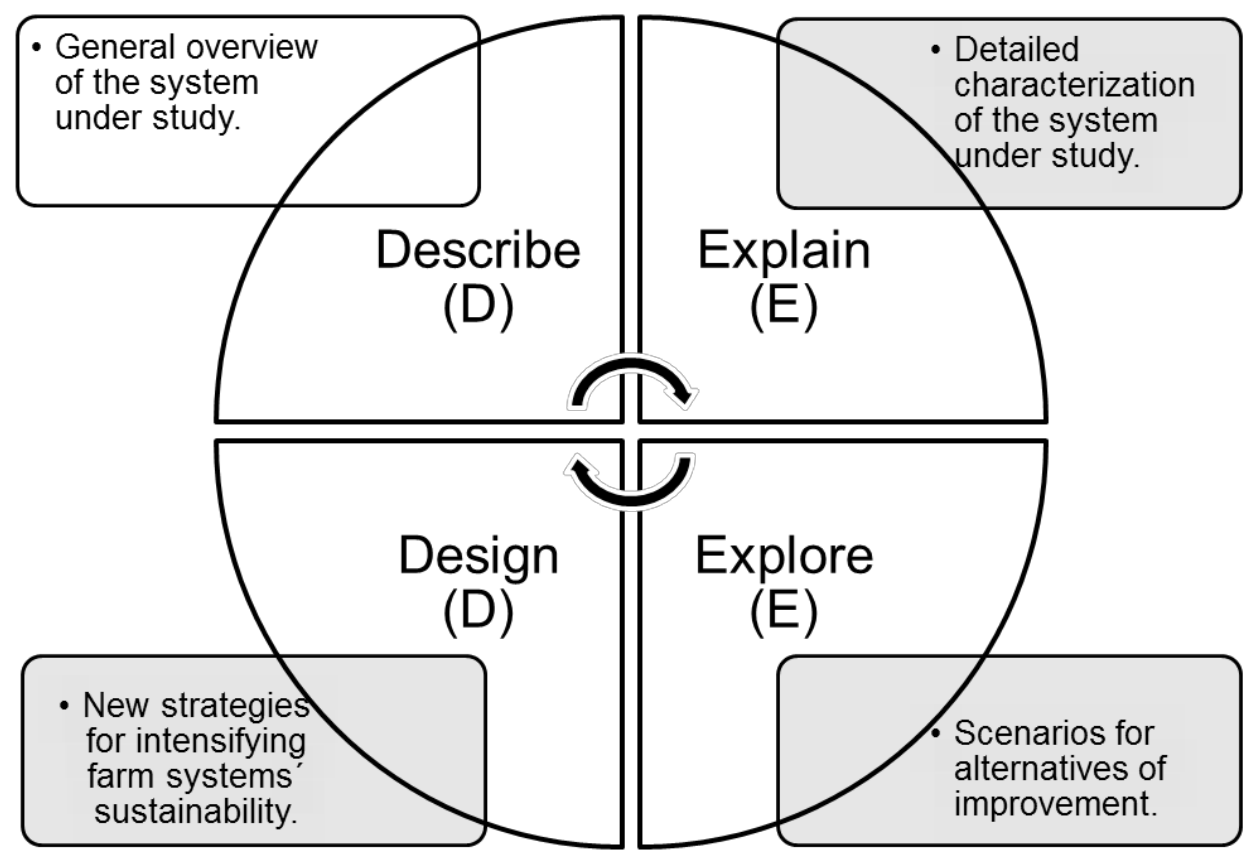

Figure 1.4. Steps of the "DEED” (Describe, explain, explore and design) farming systems analysis approach (modified from Tittonell, 2008). In the Describe step current production systems were characterized. The Explain step enabled understanding consequences of current management. Exploration of the window of opportunity in the Explore step preceded selection of options to actually implement in the Design step. The latter is beyond the scope of this thesis. 
management and performance, and the farmers to obtain a different viewpoint on their practices to enhance their knowledge of farmers' objectives. Farmers benefitted from salient feedback based on farm-specific information.

Multi-criteria decision analysis, which comprises various methods and tools for supporting decisionmaking, is used in natural resources management and for assessment of scenarios and policies (Mendoza and Martin, 2006), including farming systems analysis. In this thesis the multi-objective explorative model FarmDESIGN (Groot et al., 2012) is used during the exploration phase. The design phase where alternatives are tested with farmers is beyond the scope of this thesis (Figure 1.4). FarmDESIGN is a bio-economic model that describes farm components and their interactions in terms of nutrients, labor and economic flows. It can also be used to optimize selected objective variables simultaneously, using a Pareto-based evolutionary algorithm. The model was parameterized using quantitative information gathered through farm monitoring and field measurements and experiments. For exploration of alternative farm systems, crop and animal production activities were formulated from a short planning horizon perspective, i.e. based on those already existing in the area, so that they could be applied immediately by farmers.

Unexpected events associated with climate, crop or animal diseases, market volatility or policies or new technology may have different effects on farm performance, depending on the farm strategy (Pannell et al., 2000). Direct impacts on one subsystem may indirectly affect multiple other subsystems (Darnhofer et al., 2010; Gitz and Meybeck, 2012). The response of the system to such unexpected events can be understood as the vulnerability of the system and the return time as its resilience. Vulnerability represents the magnitude of change of systems after a disturbance without changing its function (Miller et al., 2010), and resilience is the capacity of the systems to absorb disturbances and reorganize while undergoing change so as to still retain the same function and structure (Walker et al., 2009; Miller et al., 2010). Analysis of the resilience of a farming system to disturbances and how resilience changes under different farm strategies provides a new perspective on desirable development trajectories. Different theoretical models and practical approaches exist to analyze vulnerability and resilience of agro-ecosystems at different spatial and temporal scales (Darnhofer et al., 2010; Eakin et al., 2012; Gitz and Meybeck, 2012; Ifejika, 2013; Tittonell, 2014). Nonetheless, analyzing and assessing vulnerability and resilience at the farm systems scale remains challenging, while this information may be critical to guide transformation of agricultural systems to a less vulnerable and more resilient state (Darnhofer et al., 2010; Miller et al., 2010). The final methodological step in the thesis is to develop and apply a quantitative approach to analyze and assess vulnerability and resilience.

This work was developed as part of the international project EULACIAS (acronym that stands for European Latin American Co-Innovation of Agro-ecoSystems). The project aimed at reversing unsustainable use of farm resources and insufficient economic results of smallholder farming systems 
in Latin America by combining 'hard' and 'soft' systems approaches, social learning by all actors, and dynamic project monitoring. The project explored viable livelihood options in three case study regions (Argentina, Uruguay and Mexico), with different agricultural systems (vegetable crops, cherry orchards, and dairy farms, respectively). In all cases, participatory methods for innovation were combined with a toolkit of quantitative agroecosystem simulation models in an approach that brought together scientists and stakeholders. This thesis describes particularly the 'hard' systems approaches brought to bear in the Mexican case study.

\subsection{Outline of the thesis chapters}

In Chapter 2, a dairy farm typology is developed to classify farm diversity based on structural and functional variables in a sample of 97 dairy farms randomly selected in the region. Multivariate statistical tools including Principal Component Analysis and Hierarchical Cluster Analysis are applied. Two dairy farming systems classified as family-based and semi-specialized, and three levels of farming intensity (extensive, medium-intensive and intensive) are identified. One dairy farm of each type is selected as pilot farm (six in total) and used in the subsequent chapters of this thesis.

Chapter 3 presents a detailed diagnosis of the main factors that affect productivity and efficiencies of nutrient use at the animal, crop and farm level for the six pilot farms that represent key farm clusters identified in the preceding analysis. Current yield gaps at the level of individual crops and animal herds are compared to those at the farm level (farm productivity gaps).

In Chapter 4, sustainable intensification options are explored for each of the farm types. Solutions are explored in terms of trade-offs among five objectives: maximization of farm profit and of soil organic matter, and minimization of nitrogen balances, labor demands and of feed costs.

Chapter 5 assesses vulnerability of current and newly re-designed dairy farming systems to shocks and their resilience, using an explorative whole-farm model. This analysis assumes a sharp reduction in forage maize production as a disturbance, and assesses the capacity for recovery under different assumptions on available management options of the farms under study.

Chapter 6 discusses the general findings from this study and the contribution made to improve farming systems. Moreover, it is discussed how the methodology implemented in this thesis may support other researches for similar agro-ecosystems.

\subsection{References}

Aguilar, A., and López, M., 2006. Cómo lograr que la ganadería lechera mexicana sea competitiva a nivel internacional. Revista Mexicana de Agronegocios X (18): 1 - 14.

Albo, A., and Ordaz D., J.L., 2011. La Migración Mexicana hacia los Estados Unidos: Una breve 
radiografía. BBVA Research. Documento de trabajo 11/05. 15 p.

Alexander, P., Rounsevell, M.D.A., Dislich, C., Dodson, J.R., Engström, K., and Moran, D., 2015. Drivers for global agricultural land use, change: The nexus of diet, population, yield, and bioenergy. Global Environmental Change 35: 138 - 147.

Alexandratos, N., and Bruinsma, J., 2012. World agriculture towards 2030/2050: The 2012 revision. Rome, FAO. ESA Working paper No. 12-03. 147 p.

Arriaga-Jordán, C.M., Albarrán-Portillo, B., Espinoza-Ortega, A., García-Martínez, A., and CastelánOrtega, O.A., 2002. On-farm comparison of feeding strategies based on forages for smallscale dairy production systems in the highlands of Central Mexico. Expl. Agric. 38: 375 388.

Bravo-Garza, M.R., and Bryan, R.B., 2005. Soil properties along cultivation and fallow time sequences on vertisols in Northaestern Mexico. Soil Sci. Soc. Am. J. 69: 473 - 481.

Castelán-Ortega, O.A., Fawcett, R.H., Arriaga-Jordán, C., and Herrero, M., 2003a. A decision support system for smallholder campesino maize-cattle production system of the Toluca Valley in Central Mexico. Part I - Integrating biological and socio-economic models into a holistic system. Agricultural Systems 75: 1 - 21.

Castelán-Ortega, O.A., Fawcett, R. H., Arriaga-Jordán, C., and Herrero, M., 2003b. A decision support system for smallholder campesino maize-cattle production system of the Toluca Valley on Central Mexico. Part II - Emulating the farming system. Agricultural Systems 75: 23 - 46.

Cervantes, F., and Cesín, A., 2007. La pequeña lechería rural o urbana en México y su papel en el amortiguamiento de la pobreza. Revista Unellez de Ciencia y Tecnología 25: 72 - 85.

Cervantes G., J.A., 2012. Comportamiento reciente del ingreso de México por remesas familiares. Centro de Estudios Monetarios Latinoamericanos, Asociación Regional de Bancos Centrales. $14 \mathrm{p}$.

Colunga, G.B., Villa-Méndez, C.I., Tzintzun-Rascón, R., Tena-Martínez, M.J., and Val-Arreola, D., 2009. La caracterización socioeconómica de los sistemas campesinos de producción en pequeña escala de la cuenca lechera Morelia-Álvaro Obregón, Michoacán. Livestock Research for Rural Development 21 (159). In: http://www.lrrd.org/lrr21/10/colu21159.htm. Date retrieved: May, 2011.

CONAGUA (Comisión Nacional del Agua), 2002. Determinación de la disponibilidad de agua en el acuífero Ciénega de Chapala, estado de Jalisco. Subdirección General Técnica, Gerencia de Aguas Subterráneas. D.F., México. 12 p.

CONAGUA (Comisión Nacional del Agua), 2011. Estadísticas del agua en México. Secretaría de Medio Ambiente y Recursos Naturales (Ed.). D.F., México. 181 p.

CONEVAL, 2013. Análisis y medición de la pobreza: Lineas de bienestar y canasta básica. In: http://www.coneval.gob.mx/Medicion/Paginas/Lineas-de-bienestar-y-canasta-basica.aspx. 
Date retrieved: April, 2013.

Darnhofer, I., Fairweather, J., and Moller, H., 2010. Assessing a farm's sustainability: insights from resilience thinking. International Journal of Agricultural Sustainability 8(3): 186 - 198.

Espinosa O., V., López D., C., García B., G., Gómez G., L., Velásquez P., P., and Rivera H. G., 2002. Marketing margins of bovine crude milk produced at family systems. Revista Científica XII (2): $650-654$.

Espinosa O., V. E., Rivera H., G., and García H, L. A., 2007. Utilidades económicas generadas por la lechería familiar. Sociedades Rurales, Producción y Medio Ambiente 7(14): 19 - 41.

Espinosa O., V. E., Rivera H., G., and García H., L. A., 2008. Marketing channels and margins of raw milk produced in a family system (case study). Vet. Méx. 39(1): 1 - 16.

Espinoza-Ortega, A., Álvarez-Macías, A., del Valle, M. del C., and Chauvete, M., 2005. Small-holder (campesino) milk production systems in the highlands of Mexico. Téc Pecu Méx 43(1): 39 56.

FAO. 2012. Statistical database. In: http://faostat.fao.org/site/291/default.aspx. Retrieved: October, 2012.

Gitz, V., and Meybeck, A., 2012. Risks, vulnerabilities and resilience in a context of climate change. in: FAO/OECD Workshop: Building resilience for adaptation to climate change in the agricultural sector, Rome, Italy, 23-24 April. [online] URL: http://typo3.fao.org/fileadmin/templates/agphome/documents/faooecd/gitz.pdf.

González, L. 1995. Pueblo en vilo. $5^{\text {th }}$ Edition. El Colegio de Michoacán. Michoacán, Mexico. 458 p.

Groot, J.C.J., Oomen, G.J.M., and Rossing, W.A.H., 2012. Multi-objective optimization and design of farming systems. Agricultural Systems 110: 63 - 77.

Gustavsson, J., Cederberg, Ch., Sonesson, U., and Van Otterdijk, R., 2011. Global food losses and food waste. Food and Agricultural Organization of the United Nations. Rome, Italy. 29 p.

Herrero, M., Thorton, P.K., and Gerber, P., 2009. Livestock, livelihoods and the environment: understanding the trade-offs. Current Opinion in Environmental Sustainability 1: $111-120$.

Herrero, M., Thorton, P.K., Notenbaert, A.M., Wood, S., Msangi, S., Freeman, H.A., Bossio, D., Dixon, J., Peters, M., Van de Steeg, J., Lynam, J., Parthasathy R., P, Macmillan, S., Gerard, B., McDermott, J., Seré, C., and Rosegrant, M., 2010. Smart investment in sustainable food production: Revisiting mixed crop-livestock systems. Science 327: 822 - 825.

Herrero, M., Thornthon, P.K., Notenbaert, A., Msangi, S., Wood, S., Kruska, R., Dixon, J., Bossio, D., Van de Steeg, J., Freemna, H.A., Li, X., and ParthasarathyRao, P., 2012. Drivers of change in crop-livestock systems and their potential impacts on agro-ecosystems services and human wellbeing to 2030: A study commissioned by the CGIAR Systemwide Livestock. International Livestock Research Institute (ILRI). 101 p.

INEGI, 2010. Censo de población y vivienda 2010. In: 
http://www3.inegi.org.mx/sistemas/mexicocifras/default.aspx?src=487\&e=16. $\quad$ Retrieved: February, 2013.

INEGI, 2012. Empleo informal en México: Boletín de prensa Núm. 449/12. In: http://www.inegi.org.mx/inegi/contenidos/espanol/prensa/.../comunica3.doc. Retrieved: February, 2013.

INEGI, 2013. Migración internacional de México al cuarto trimestre de 2012. In: http://www.inegi.org.mx/inegi/contenidos/espanol/prensa/boletines/boletin/Comunicados/Esp eciales/2013/Abril/comunica.pdf. Retrieved: May, 2013.

Lara-Covarrubias, D., Mora-Flores, J.S., Martínez-Damián, M.A., García-Delgado, G., OmañaSilvestre, J.M., and Gallegos-Sánchez, J., 2003. Competitividad y ventajas comparativas de los sistemas de producción de leche en el Estado de Jalisco, México. Agrociencia 37: 85 94.

Lynam, T., de Jong, W., Sheil, D., Kusumanto, T., and Evans, K., 2007. A review of tools for incorporating community knowledge, preferences, and values into decision making in natural resources management. Ecology and Society 12 (1): 15 p.

Luers, A.L., Lobell, D.B., Sklar, L.S., Addams, C.L., and Matson, P.A., 2003. A method for quantifying vulnerability, applied to the agricultural system of the Yaqui Valley, Mexico. Global Environmental Change 13: 255 - 267.

Luers, A.L., 2005. The surface of vulnerability: An analytical framework for examining environmental change. Global Environmental Changes 15: 214 - 223.

Mendoza, G.A., and Martins, H., 2006. Multi-criteria decision analysis in natural resources management: A critical review of methods and new modeling paradigms. Forest Ecology and Management 230:1 - 22.

Miller, F., Osbahr, H., Boyd, E., Thomalla, F., Bharwani, S., Ziervogel, G., Walker, B., Birkmann, J., Van der Leeuw, S., Rockström, J., Hinkel, J., Downing, T., Folke, C., and Nelson, D., 2010. Resilience and vulnerability: Complementary or conflicting concepts?. Ecology and Society 15(3): 11.

OECD (Organization for Economic Co-operation and Development), 2006. Agricultural and fisheries policies in Mexico: Recent achievements, continuing the reform agenda. Paris, France. 328 p.

OECD (Organization for Economic Co-operation and Development), 2013. Annual unemployment rate. In: http://stats.oecd.org/Index.aspx?DatasetCode=MEILABOUR. Retrieved: February, 2013.

Pinos-Rodríguez, J.M., García-López, J.C., Peña-Avelino, L.Y., Rendón-Huerta, J.A., GonzálezGonzález, C., and Tristán-Patiño, F., 2012. Environmental regulations and impacts of manure generated by livestock operations in some American countries. Agrociencia 46(4): 359 - 370.

Reséndiz, S., 1986. San José de Gracia-Jiquilpan: Un caso de economía ganadera. In: C. Herrejón 
(Coord.), Estudios Michoacanos II. El Colegio de Michoacán. Michoacán, México: 227 243.

Reyes T., M., 2008. La importancia de las remesas familiares en la economía mexicana, 1990-2007. Cámara de Diputados, LX Legislatura. D.F., México. 30 p.

Romero P., J., Vargas U., G., García G., J.O., Pulido S., J., Peña P., F., Rebollar A., Á., and Rivera M. D., 2001. Agricultura, población y deterioro de recursos naturales en Michoacán diagnóstico y propuestas. Universidad Autónoma Chapingo. Edo. de México, Mexico. 352 p.

SAGARPA, 2000. Situación actual y perspectiva de la producción de leche de ganado bovino en México 1990-2000. Secretaría de Agricultura, Ganadería, Desarrollo Rural, Pesca y Alimentación. In: <http://www.sagarpa.gob.mx/ganaderia/Publicaciones/Lists>. Retrieved: July, 2011.

SAGARPA, 2008. Tratado de Libre Comercio de América del Norte: Sector agroalimentario. In: http:// oiedrus-durango.gob.mx/TLC.pdf. Retrieved: April, 2013.

SAGARPA, 2010a. Programa de apoyos directos al campo (PROCAMPO): Resultados principales 2009. Claridades 200: $34-47$.

SAGARPA, 2010b. Producción pecuaria sustentable y ordenamiento ganadero y apícola (PROGAN 2008-2012). Claridades 207: 12 - 18 .

SAGARPA, 2011. Boletín de Leche: Julio-Septiembre. In: http://www.siap.gob.mx/index.php?option=com_content\&view=article\&id=51\&Itemid=381. Retrieved: August, 2012.

Sánchez G., L.G., Solorio R., J.L., and Santos F., J., 2008. Factores limitativos al desarrollo del sistema familiar de producción de leche, en Michoacán, México. Cuadernos Des. Rural, Bogotá (Colombia) 5 (60): 133 - 146.

Sánchez R., G., and Sánchez V., A., 2005. La ganadería bovina del estado de Michoacán: Más de cuatro siglos de tradición y cultura ante los retos del nuevo milenio. Fundación Produce Michoacán, A. C. Michoacán, México. 165 p.

SE (Secretaría de Economía), 2012. Análisis del sector lácteo en México. Secretaría de Economía. In: http://www.economia.gob.mx/files/comunidad_negocios/industria_comercio/informacionSec torial/analisis_sector_lacteo.pdf. Retrieved: November, 2012.

Secretaría de Gobierno, 2010. H. Ayuntamiento Constitucional de Marcos Castellanos: Plan de Desarrollo Municipal. Periódico Oficial del Gobierno Constitucional del Estado de Michoacán de Ocampo. Morelia, Michoacán. Tomo CXLIX, Núm. 46: 16 p.

SEDESOL, 2013. Unidad de microrregiones: Cédulas de información municipal. In: http://www.microrregiones.gob.mx/zap/Economia.aspx?entra=nacion\&ent=16\&mun=051.

Retrieved: February, 2013.

SEMARNAT, 2003. Elaboración de diagnóstico y plan de manejo en la microcuenca San José de 
Gracia, Municipio de Marcos Castellanos, Michoacán. Secretaría de Medio Ambiente y Recursos Naturales, Michoacán, México.

Schwentesius R., R., Gómez C., M.A., Trujillo, J.D., and Durán F., P., 2007. Metaevaluación de tres evaluaciones oficiales de la SAGARPA del programa de pagos directos (PROCAMPO) a la agricultura mexicana. Estudios Sociales 16 (30): 104 - 134.

Sotelo, E., Cardona, N., Fregoso, A., Enríquez, C., Garrido, A., Caire, G., and Cotler, H., 2005. Acciones estratégicas para la recuperación de la cuenca Lerma-Chapala: Recomendaciones técnicas para las diecinueve subcuencas. Instituto Nacional de Ecología. 113 p.

Steinfeld, H., Wassenaar, T., and Jutzi, S., 2006a. Livestock production systems in developing countries: status, drivers, trends. Rev. sci. tech. off. int. Epiz. 25 (2): 505 - 516.

Steinfeld, H., Gerber, P., Wassenaar, T., Castel, V., Rosales, M., and de Haan, C., 2006b. Livestock's long shadow: Environmental issue and options. Food and Agricultural Organization of the United Nations. Rome, Italy. 390 p.

Steinfeld, H., and Gerber, P., 2010. Livestock production and the global environment: Consume less or produce better?. PNAS 107(43): 18237 - 18238.

Taddese, G., Mohamed, M.A., and Ayalneh, W., 2002. Effect of livestock grazing on physical properties of a cracking and self-mulching Vertisol. Australian Journal of Experimental Agriculture 42: 129 - 133.

Tittonell, P. 2008. Msimu wa Kupanda: Targeting resources within diverse, heterogeneous and dynamic farming systems of East Africa. Unpublished Ph.D. dissertation. Wageningen University, The Netherlands. In: http://edepot.wur.nl/121949. Retrieved: February, 2013.

UN (United Nations), 2006. World urbanization prospects: The 2005 revision. Department of Economic and Social Affairs, Population Division. United Nations, New York. 196 p.

Val-Arreola, D., Kebreab, D., Mills, J.A.N., Wiggins, S.L., and France, J., 2004. Forage production and nutrient availability in small-scale dairy systems in Central Mexico using linear programming and partial budgeting. Nutrient Cycling in Agroecosystems 69: 191 - 201.

Val-Arreola, D., Kebreab, D., and France, J., 2006. Modeling small-scale dairy farms in Central Mexico using multi-criteria programming. J. Dairy Sci. 89: 1662 - 1672.

Velázquez, A., Mas, J.F., Díaz G., J.R., Mayorga S., R., Alcántara, P.C., Castro, R., Fernández, T., Bocco, G., Ezcurra, E., and Palacio, J. L., 2002. Patrones y tasas de cambio de uso del suelo en México. Gaceta Ecológica: 21 - 37.

Walker, B. H., Abel, N., Anderies, J.M., and Ryan, P., 2009. Resilience, adaptability, and transformability in the Goulburn-Broken catchment, Australia. Ecology and Society 14(1): 12. In: http://www.ecologyandsociety.org/vol14/iss1/art12/. Retrieved: February, 2013.

Zarazúa-Escobar, J.A., Almaguer-Vargas, G., and Ocampo-Ledezma, J.G., 2011. The direct field support program (PROCAMPO) from and its impact on agricultural productive and 
commercial knowledge management in Estado de México. Agricultura, Sociedad y Desarrollo 8 (1): 89 - 105. 


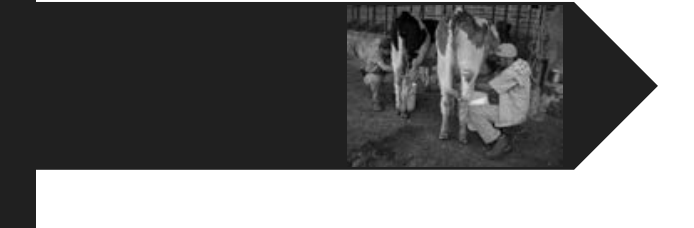

Chapter 2: Leverages for on-farm innovation from farm typologies? An illustration for family-based dairy farms in North-west Michoacán, Mexico

José Cortez-Arriola, Walter A.H. Rossing, Ricardo D. Améndola Massiotti, Johannes M.S. Scholberg, Jeroen C.J. Groot, and Pablo Tittonell. 


\begin{abstract}
Knowledge on farm diversity provides insight into differences among farms, enables scaling from individual farm to farm population level and vice versa, and has been used in the definition of recommendation domains for introduction of novel technologies. Farm diversity can be broadly described in terms of resource endowment and resource use strategy, or in other words, in terms of scale and intensity of production. Measuring intensity of production requires much greater monitoring effort than measuring scale of production, and often only proxies of production intensity are used. Using data from a regional farm survey and from intensive on-farm monitoring the question addressed in this paper is to which extent results of farm surveys that measure primarily scale of production can inform on-farm interventions aimed at improving farm performance. The survey included a random sample of 97 out of 664 smallholder dairy farmers in a community in north-west Michoacán, Mexico. Farm types were identified by a combination of Principal Component Analysis to reduce the dimensionality of the dataset, followed by Cluster Analysis. The survey was complemented with detailed analyses of costs, revenues and productivity on 6 farms over the course of one year. Survey results revealed considerable variation among the dairy farms in land area, livestock units, amount of hired labour, and infrastructure and equipment, which led to the distinction of 4 farm types. Indicators for animal health management and feeding strategies were uniform across the 4 types. The farm types matched the distinction of family-based and semi-intensive farm types used in Mexico. The detailed analyses of the individual farms belonging to the different types, however, revealed differences in resource use strategies reflected in differences in animal productivity, labour productivity and return to labour. Differences in animal productivity and labour productivity were explained by stocking rate, albeit in different ways. Return to labour was strongly related to cost of feed. Profitability was negative for all farms and was on most farms related to high external feedstuff costs, which constituted $59-89 \%$ of the feed cost of the animal ration. The results indicate that in addition to variables reflecting resource endowment or scale of production, typologies that aim to inform on-farm interventions need to consider farm characteristics that reflect intensity of production. Which variables should be selected will need to be determined in a preliminary assessment. To enhance internal resource use efficiency as was the purpose in the current study, candidate variables expressing intensity could include the share of external feed in the ration and proxies of internal resource use, e.g. reflected in crop and milk yields. Opportunities for on-farm innovation arising from the analyses are discussed from the perspective of labour flexibility, low costs and use of internal resources.
\end{abstract}

Keywords: Multivariate analysis; farm typology; economic analysis; production costs; external dependency; farm yield gaps; farm profitability.

Published in Agricultural Systems, 2015, 135: 66-76. Doi: 10.1016/j.agsy.2014.12.005. 


\subsection{Introduction}

Despite being the largest economy of Latin America after Brazil, Mexico is among the largest importers of dairy products in the world, particularly powder milk. Annual imports over the past 30 years increased by about 0.05 Mton annually and achieved values of approximately 3 Mton in the first years of this century, equivalent to over 20\% of national milk demand (FAO, 2011 in Wattiaux et al., 2012). In Mexico milk is produced on about 150,000 farms (SAGARPA, 2011), 83\% of which are family-based. Milk production, ranking third in value of domestic agricultural products, increased substantially after the year 2000 due to increases in numbers of cows. Average cow productivity has been estimated as 4000 - $5000 \mathrm{~kg}$ milk per cow per year, and remained unchanged for the last 25 years (Amendola, 2002; Wattiaux et al., 2012). From the mid 1960’s to early 1990's the Mexican government implemented a number of policies aimed at reducing the dependence on imported agricultural commodities, supporting farmers through subsidies and funding schemes (e.g. CONASUPO, established in 1965) (OECD, 2006). Trade liberalisation triggered by Mexico joining the North American Free Trade Agreement (NAFTA) since 1994 resulted in withdrawal of governmental support to family farmers and considerable drop in prices of agricultural commodities. Despite direct income support programs such as PROCAMPO, government expenditure on rural communities has been decreasing and the chronic erosion of rural livelihoods and lack of local employment opportunities are important causes of the high rates of rural emigration (Villareal \& Hamilton, 2012). Mexico has the largest and longest sustained international flow of migrants worldwide, most of which go to the United States (Hunter et al., 2013). This poses a serious threat to rural and agricultural development and to national food security.

In Mexico four types of dairy production systems are commonly distinguished: specialized, semispecialized, family-based, and dual purpose, comprising $17,15,8$, and $60 \%$ of the dairy farms and 50 , 21,9 , and $20 \%$ of production, respectively (SAGARPA, 2007). Dual purpose systems produce milk and meat, and are usually run by the farm family. They are particularly found in the tropical and subtropical zones, and are marked by low productivity, pasture-based feeding and strong seasonal fluctuations. Specialized systems use high levels of external inputs and intensive management practices, have hundreds to thousands of dairy cattle which are fed in feedlots, and are often part of larger business conglomerates that comprise several parts of the value chain. The distinction between the categories semi-specialized and family-based farms is fairly recent (Amendola, 2002), and aimed to accommodate the large diversity among those farms in temperate regions where the family provides all or an important part of the labour. These farms range from subsistence to sharing attributes with specialized systems. Semi-specialized and family-based farms are particularly located in the west central highlands, which include the states of Jalisco, Aguascalientes, México and Michoacán. 
Farm typologies have attracted attention of agricultural scientists as a means to distinguish patterns in populations of farms. Using "farm typology" as topic search term on the Web of Science resulted in 54 publications since 1984, 48 of which were published after the year 2000. Pacini et al. (2014) consider understanding farm diversity in its multiple dimensions decisive in the design of agricultural policies and in assessing suitability of technological innovation. When considering farm diversity, a broad distinction can be made between scale of production and the intensity of production (Van der Ploeg, 2003). Scale of production relates to resource endowment e.g. amounts of land, capital and labour; intensity of production refers to production per hectare or per animal. A qualitative review of the literature suggests that farm typologies have been constructed to identify diversity per se and its underlying causes (e.g. Tittonell et al., 2005; Gaspar et al., 2008), to scale from individual farms to the farm population (often regional) level and vice versa (e.g. Righi et al., 2011), and to define recommendation or response domains for introduction of specific novel technologies (Franke et al., 2014) or policies (e.g. Andersen et al., 2007). For these purposes, focus is on finding patterns in variables that express resource endowment along with proxies for intensity of production, particularly when studies focused on less developed countries where farm management data are scarce. Such typologies, however, may not be useful to identify opportunities for on-farm innovation when technologies are not pre-defined but the aim is to mobilize a customized mix of technologies to address key weaknesses in farm performance.

From 2007 to 2010 a project was carried out, aimed at improving farm-level productivity as one of the means to reverse marginalization of Mexican family-based dairy farmers. The project focused on an area in the north-west of Michoacán where dairy farming was the main agricultural activity. Visits and pre-analytical research by the Autonomous University of Chapingo had raised interest among the local farmers for a development-oriented study in which existing productivity-improving technologies would be introduced to farms that showed promise to benefit from the interventions. The first phase of the project consisted of an assessment of farm diversity as a precursor to engagement in on-farm innovation. While data on resource endowment of the dairy farms in the region could be collected relatively easily through surveys, establishing intensity of production of family-based dairy farms required time-intensive monitoring of milk production and grassland and herd management as farmers had no tradition of keeping records.

Using data from a regional farm survey and from intensive on-farm monitoring the question addressed in this paper is to which extent results of farm surveys that measure primarily scale of production can inform on-farm interventions aimed at improving farm performance. 


\subsection{Material and methods}

\subsubsection{Case study region}

The municipality of Marcos Castellanos is located in the north-west of Michoacán State, Mexico (19 $\mathrm{N}$ and $103^{\circ} \mathrm{W}$ ) at altitudes between 1,500 and 2,400 $\mathrm{m}$ above sea level. Climate is temperate with a rainy season between June and October, and rainfall and temperature averages of $798 \mathrm{~mm}$ and $18.9^{\circ} \mathrm{C}$, respectively. Vertisols, luvisols, and litosols are the main soil types in the region (SEMARNAT, 2003), arranged on hills with gentle slopes with intermittent ravines and small nearly flat areas. The original vegetation types include mostly thorny and broadleaf forests. The area of the municipality is $233 \mathrm{~km}^{2}$, of which $86 \%$ is rangeland and $12 \%$ is cropland, which is used mostly for forage maize production.

Livestock activities dominate the agricultural landscapes of northwest Michoacán State since the Spanish colonizers introduced cattle, sheep and pigs in 1545 (González, 1992). The development of road networks in rural areas coupled with increasing human populations in nearby urban centers favoured the establishment of an important dairy sector towards the end of the nineteenth century. Despite soil constraints and strong seasonality of rainfall, Michoacán accounts for 3.2\% of the national milk production and is ranked as the $12^{\text {th }}$ largest milk producing state (SAGARPA, 2011). Since 2000, the volume of milk produced in Michoacán increased by 1.2\% annually, but productivity per animal remained constant. Although the area of Marcos Castellanos only accounts for $0.39 \%$ of Michoacán, the municipality is the largest milk producer and supplies $11 \%$ of the state's production (SAGARPA, 2012). Livestock production and dairy industry are the main economic activities in the region. Farms sell their milk either directly to large dairy processors or through local cooperatives. Various breeds of cattle are used, with a predominance of Holstein Friesian and Jersey, often as crosses with Zebu or Brown Swiss. Cows are mostly grazed on rangeland, which is sometimes improved with high production grass species and only occasionally replaced by sown pastures. Farmers buy concentrates as a baseline feed strategy and to overcome periods of low forage production. Most farmers grow some maize for feed, often by continuous cropping of hybrid maize varieties with inputs of herbicides and NPK fertilizers. Producing silage requires a higher level of mechanization and knowledge than available on small farms, but contractors facilitate adoption in the region. Traditionally, maize is conserved as ground maize obtained by grinding field-dried entire maize plants into pieces smaller than $5 \mathrm{~cm}$ length. Ground maize is considered to be a low-cost alternative to ensiling maize.

\subsubsection{Farm survey and typology}

In 2007 a survey was carried out in the municipality to provide the database for a farm typology. From the 664 dairy farmers that constituted the census of the regional association of dairy farmers, 97 (14.6\%) were randomly selected to be visited by one of three teams of 2 technicians who interviewed 
the farm leader. Each interview was conducted on the farm and took about 90 minutes. The survey questionnaire included four categories of questions: biophysical resources, physical resources, socioeconomic resources, and system management. Per category one to four variables were recorded (Table 2.1). Biophysical resources were measured as livestock numbers and land, distinguishing the areas owned and rented, as well as those used for grazing and cropping. Availability of off-farm income was described as a semi-quantitative variable with three levels: off-farm work, remittances, or both sources of income. Physical resources, feeding management and animal health management were summarized in indices. All three indices were built as weighted sums, with the weights representing local farmers' opinion on the importance of an item for 'good farming practice'. The physical resources index represented the weighted sum of the number of pieces of equipment and permanent facilities available on the farm. Based on the on-farm observations during the survey, the research team made a list of 32 major pieces of equipment and permanent facilities. Farmers and advisors were asked to give weights.

Table 2.1. Variation among family-based dairy farms in Marcos Castellanos, Michoacán, Mexico, based on an on-farm survey in 2007 among 97 out of 664 farms. CV is coefficient of variation, expressed as fraction.

\begin{tabular}{|c|c|c|c|c|c|c|c|}
\hline Category & Survey variable & Unit & Minimum & Maximum & Mean & $\mathrm{CV}$ & Median \\
\hline \multirow{4}{*}{$\begin{array}{l}\text { Biophysical } \\
\text { resources }\end{array}$} & Land owned & ha & 0 & 210 & 29 & 1.5 & 10 \\
\hline & Land rented & ha & 0 & 200 & 29 & 1.4 & 15 \\
\hline & Grazing land & ha & 0 & 235 & 46 & 1.2 & 22 \\
\hline & Livestock & $\mathrm{LU}^{1}$ & 2 & 196 & 53 & 0.8 & 39 \\
\hline $\begin{array}{l}\text { Physical } \\
\text { resources }\end{array}$ & $\begin{array}{l}\text { Infrastructure and } \\
\text { equipment }\end{array}$ & Index $^{2}$ & 0.1 & 9.5 & 2.6 & 0.7 & 1.9 \\
\hline Socio- & Off-farm income & Index $^{3}$ & 0.0 & 1.0 & 0.30 & 1.1 & 0.5 \\
\hline economic & Hired labor & Labor-day $\mathrm{y}^{-1}$ & 0 & 1610 & 229 & 1.6 & 12 \\
\hline resources & Family labor & Labor-day $\mathrm{y}^{-1}$ & 0 & 4680 & 880 & 0.8 & 720 \\
\hline System & Feeding & Index $^{4}$ & 2.7 & 41.3 & 15.5 & 0.4 & 15.0 \\
\hline management & Animal health & Index ${ }^{5}$ & 0.5 & 2.9 & 1.6 & 0.3 & 1.7 \\
\hline
\end{tabular}

\footnotetext{
${ }^{1}$ A livestock unit (LU) is defined as customary in Mexico as a $450 \mathrm{~kg}$ LW lactating cow with a calf younger than 7 months.

${ }^{2}$ Weighted sum of numbers of pieces of equipment (e.g. livestock scale, truck, forage mincer) and permanent facilities (e.g. feeding troughs, field fences, milking parlors) available on the farm. Weights represent dominant opinion on the importance of the various items for a wellfunctioning farm. Maximum value of the index was 11.6.

${ }^{3}$ Categorical variable: 0 represents no off-farm income, 0.5 represents income from off-farm work or remittances, and 1 represents income from both off-farm work and remittances.

${ }^{4}$ Weighted sum of feeding system (year-round confinement, semi-confinement and year-round grazing) and types of feed sources. Weights represent dominant opinion on what constitutes a good feeding system and good sources of feed. Maximum value of the index was 51.6.

${ }^{5}$ Weighted sum of strategies and tactics brought to bear to manage animal health by preventative and curative measures. Maximum value of the index was 3.6.
} 
Among the listed items, a well, a truck, a silo, a milking parlour and verterinary equipment were considered important and received greatest weights, while a water trough, watering points in paddocks, management of the yard, and shadow in paddocks and yard received least weights. Maximum score was 11.6. The indices for feeding management and animal health management were constructed in similar ways, as weighted sums of feeding system elements and animal health supporting activities encountered during the survey. For feeding management, the experts distinguished feeding systems and components of feed. Year-round housing received greater weight than a mixed system of housing and grazing, or than full-time grazing. Feed components were weighted according to perceived qualities in terms of energy and protein, with crop residues and rangelands receiving least and concentrates and silages receiving greatest weights. Maximum score was 51.6. For animal health management, strategic activities directed against parasites and the absence of brucellosis and tuberculosis in the herd received greatest weights, while tactical activities such as use of clean water, use of mastitis tests and udder cleaning were given equal, lower values. Maximum score was 3.6.

A farm typology was developed based on Principal Component Analysis (PCA) combined with agglomerative hierarchical clustering analysis (AHCA). The approach has been used in many studies to categorise farms or farmers' practices (e.g. Bidogeza et al., 2009; Blazy et al., 2009; Tittonell et al., 2010; Pacini et al., 2014). The 10 survey variables from the 97 farms were standardized for comparable ranges, and subjected to PCA to reduce the dimensionality of the dataset and identify noncorrelated socio-economic indicators. The first six factors identified by PCA were used in an agglomerative hierarchical cluster analysis to identify homogeneous clusters of farms based on Euclidean distance and Ward's agglomeration method. Ward's method minimises the variance within clusters and tends to find clusters of relatively equal sizes (e.g. Köbrich et al., 2003). Groups of farms were identified by superimposing the clusters on the PCA plots at a chosen similarity level. The choice of similarity level was based on subjective inspection of the CA dendrogram, supported by statistics describing the variance (inertia) accounted for (cf. Pacini et al., 2014). The analyses were performed in XLSTAT (http:www.xlstat.com).

\subsubsection{Detailed farm type characterization}

Six farms were selected for detailed characterization. In addition to membership of a farm type, presence of both cropland and grazing land, and willingness of the farmers to participate in the detailed chacterization were used as criteria for farm selection. Each farm was visited every two weeks between July 2009 and June 2010. Information was collected on amounts of forage and feedstuff used, herd composition (numbers of lactating and dry cows, heifers and bulls), milk production, expenditures, and prices of milk by measurement or inspection of farmer records. During the first visit 
an assessment was made of availability of infrastructure and equipment, and of feeding and animal health management strategies.

Net margin was calculated by subtracting the implicit costs (costs that do not imply cash expenditure) and explicit costs (the payments made to others for a service) from the total revenue (Carbaugh, 2006). Explicit costs comprised fixed and variable costs. Fixed costs included costs of permanent hired labour, rents, and electricity. In Mexico, the activity of small farmers is de facto income tax exempt. Variable costs included costs of seeds, maize forage production, veterinary support, fuel, equipment maintenance, payments for technical services, temporary labour, and purchase of animals. Depreciation of farm equipment and opportunity costs of land and family labour constituted implicit costs. Annual (linear) depreciation of each piece of equipment was calculated as the difference between purchase price and residual value, divided by the equipment's estimated life time. Estimates were obtained from local farm machinery businesses and from farmers. The opportunity cost of land was based on the average land rent in the study region. The opportunity cost of family labour was based on the most rewarding alternative occupation, which was considered to be a brick mason foreman based on farmer opinion.

Return to labour was calculated as gross margin, i.e. total revenues minus explicit costs, per unit of annual full time equivalent assuming an $8 \mathrm{~h}$ workday. Calculated labour productivity was compared to two references: the 'required minimum salary' and the opportunity cost. The required residual minimum salary represents the annual amount of money needed to cover social, cultural and educational necessities for an average family in the Mexico, as published by the government.

\subsection{Results}

\subsubsection{Farm survey and typology}

The survey demonstrated that $69 \%$ of the farms in the Marcos Castellano municipality owned less than 25 ha of land, 56\% had less than 25 ha of grazing land, while 51\% of farms had less than 40 livestock units (LU), i.e. a lactating cow of $450 \mathrm{~kg}$ live weight and a calf younger than 7 months (Figure 2.1a; Figure 2.1b). Farms were highly variable in use of hired labour (Figure 2.1c), with coefficients of variation exceeding 1 (Table 2.1). Variables related to feeding and animal health management demonstrated least variation. Farmers rented on average 50\% of the land. Most of the land (80\%) was classified as grazing land. Family labour was the main source of labour; hired labour represented 20\% of the total labour input (Table 2.1). Labour was hired for animal management, mostly on a permanent basis, and for forage maize harvesting and processing, which concerned unskilled, casual labor. Although milk production was the main source of income, many farms had another source of income, either from off-farm economic activities or from remittances. 
The availability of infrastructure and equipment was generally low, with an average index value of 2.6 (median 1.9) out of 11.6 (Table 2.1; Figure 2.1d). Only few farms owned specific installations for milking, feeding or conservation and storage of feed. Equipment for cropping and harvesting forage maize was mainly rented. The index for feeding management averaged 15.5 (median 15.0) out of a possible 51.6, implying a limited diversity of feed components per farm. Animal health management averaged 1.6 (median 1.7) out of 3.6 (Table 2.1) reflecting limited use of preventative or curative measures. Coefficients of variation for the feeding and animal health management indices were relatively low (0.4 and 0.3 , respectively) compared to the other variables, indicative of limited variability among farms.

The PCA revealed that the number of LU was strongly correlated to the area of grazing land, the amount of hired labor, infrastructure and equipment, and the area of land owned (Figure 2.2). These variables defined PC1 (Table 2.2) and explained 31.5\% of the variance, whereas PC2 explained $13.7 \%$. Due to the small percentages of variation explained by the first two principal components, hierarchical clustering was performed with the factor scores of the six principal components which together explained $84.2 \%$ of the total variance. In the cluster analysis, 5 groups of farms emerged that together captured $51 \%$ of the sum of variances (i.e. inertia) of the variables describing the 97 farms (Figure 2.2). Group 5 consisted of a single farm due to a relatively large input of family labour and large area of own land, and was excluded from further analysis as outlier.
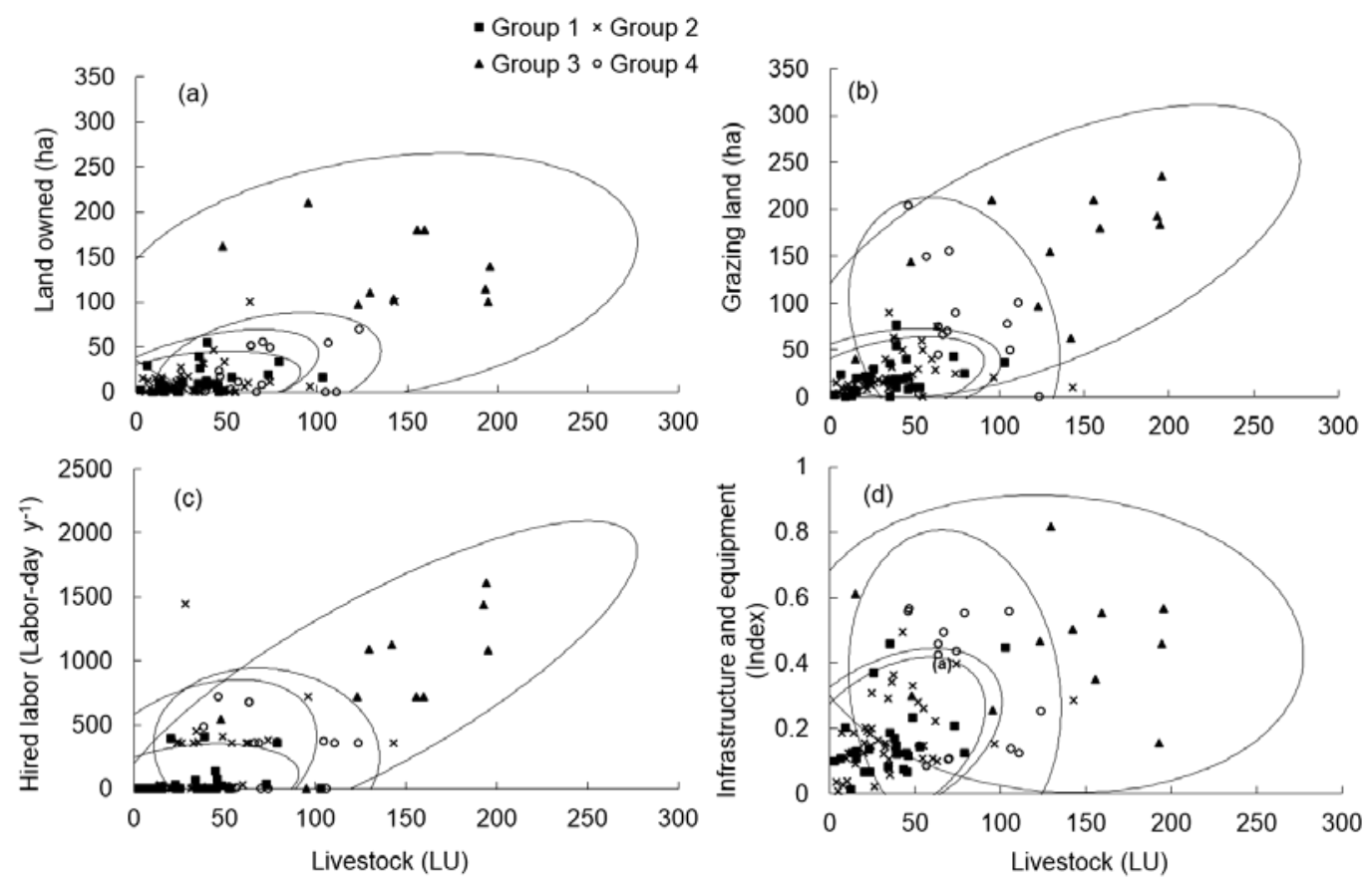

Figure 2.1. Significant associations between livestock and (a) land owned $(r=0.47, \mathrm{P}<0.01)$; (b) grazing land ( $r=0.64, \mathrm{P}<0.01)$; (c) hired labor $(\mathrm{r}=0.60, \mathrm{P}<0.01)$, and (d) normalized index of infrastructure and equipment $(\mathrm{r}=0.50, \mathrm{P}<0.01)$ per group of farms identified in the agglomerative hierarchical cluster analysis. 


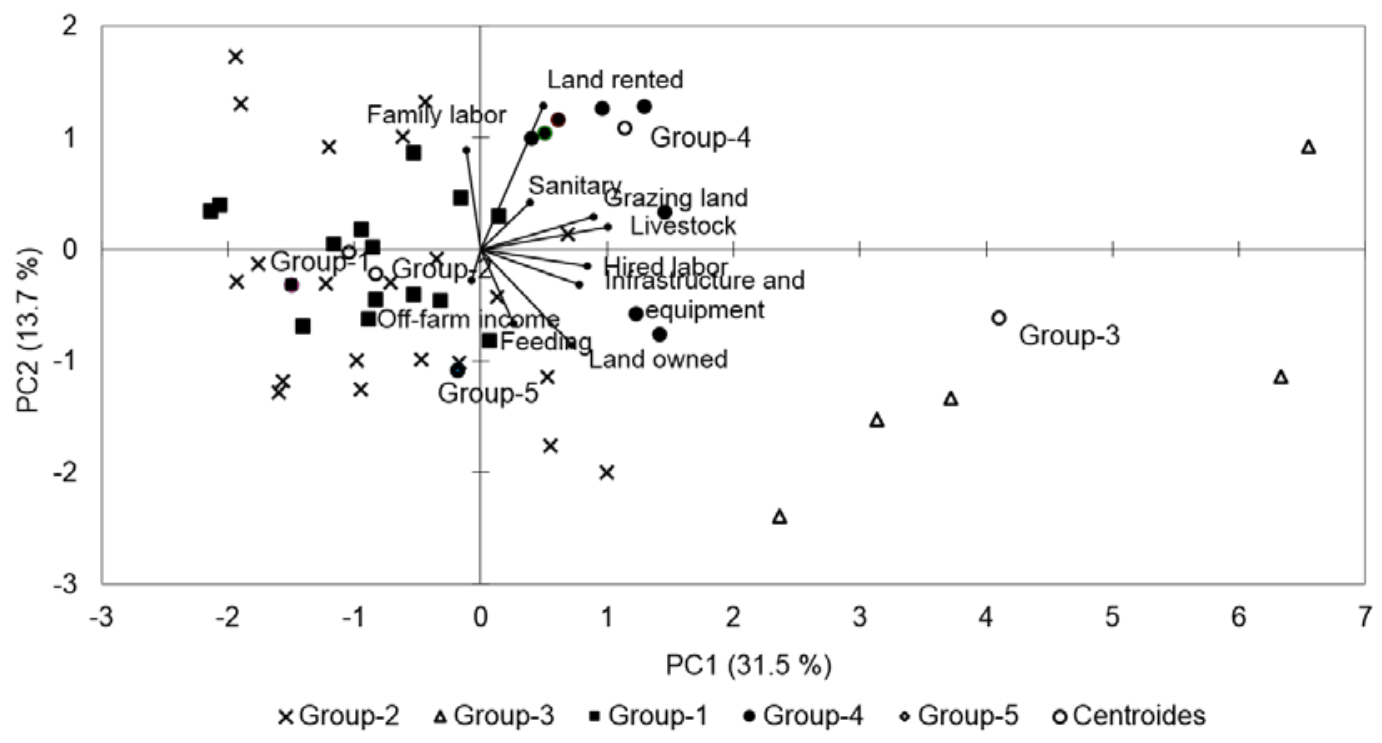

Figure 2.2. Principal components (first two axes) of dairy farms in north-west Michoacán. PC1 explains 31.5\% of variance and PC2 13.7\%. The PCA results are overlaid with individual farm data: Group 1 - family-based extensive and intermediate (FBE and FBM); Group 2 - family-based intensive (FBI); Group 3 - semi-specialized extensive and intermediate (SSE and SSM); Group 4 - semi-specialized intensive (SSI) dairy farms. Group 5 comprised one farm and was considered an outlier. Only the 50 farms with the largest contribution were plotted out of the 97 surveyed.

Table 2.2. Contribution of the survey variables to the principal components.

\begin{tabular}{llrc}
\hline Category & Variable & PC1 (\%) & PC2 (\%) \\
\hline \multirow{2}{*}{ Biophysical } & Land owned (ha) & 12.7 & 17.9 \\
resources & Land rented (ha) & 6.0 & 39.9 \\
& Grazing land (ha) & 19.3 & 2.0 \\
& Livestock (LU) & 24.6 & 1.0 \\
Physical & Infrastructure and equipment & 14.6 & 2.5 \\
resources & (Index) $^{1}$ & & \\
Socio- & Off-farm income (Index) ${ }^{1}$ & 0.1 & 1.9 \\
economic & Hired labor (Labor-day y $\left.{ }^{-1}\right)^{2}$ & 17.1 & 0.5 \\
resources & Family labor (Labor-day y $\left.{ }^{-1}\right)^{2}$ & 0.3 & 19.3 \\
System & Feeding (Index) & & 10.8 \\
management & Animal health (Index) & & \\
& & 1.6 & 4.2 \\
\hline
\end{tabular}

\footnotetext{
${ }^{1}$ The procedures to calculate the indices are summarized in Table 2.1.

${ }^{2}$ One labor-day is equivalent to 8 h of work.
} 
The distance between the centroids of groups 1 (29\% of farms) and 2 ( $42 \%$ of farms) was small (Figure 2.2); the main difference between these groups was off-farm income. Farms of group 2 received income from off-farm activities and remittances, whereas group 1 farms only received onfarm income (Table 2.3). Both groups consisted of small farms with an average land area of 28 ha, an average herd size of $35 \mathrm{LU}$ and a large proportion of grazing land (Table 2.3; Figure 2.1b). The farm family supplied most labour, on average 93\% in group 1 and $86 \%$ in group 2 . These characteristics coincide with "family-based" farms (FB) in the Mexican dairy systems classification (SAGARPA, 2007). The proportion of rented land in groups 1 and 2 was high and scores of infrastructure and equipment and of animal health management were relatively low (Table 2.3). On these farms milking was mostly done by hand in an open area or under a small roofed shelter, cows received supplementary feeding in makeshift feeding troughs, and the equipment for cropping and harvesting forage maize was rented.

Groups 3 (11\% of farms) and 4 (18\% of farms) were located on the right side of the PCA graph (Figure 2.2) with a large distance between centroids reflecting distinct differences in biophysical and physical resources such as livestock and land areas (Figure 2.1a; Figure 2.1b). Compared to groups 1 and 2, groups 3 and 4 consisted of farms with larger total land area (on average 182 and 104 ha for groups 3 and 4, respectively), more animals (144 and $70 \mathrm{LU}$ ), a smaller proportion of family labour (35 and 78\%), better infrastructure and equipment, and more attention for animal health management (Table 2.3). In the Mexican classification, the farms in groups 3 and 4 are more close to the category "semi-specialized" (SS), which like family-based farms draw on family labour, but in their strategy resemble more the specialized systems (Améndola, 2002; Wattiaux et al., 2012). Group 3 farms owned more land and animals than farms in group 4 and had more infrastructure and equipment, with bigger and mechanized milking parlors, concrete feeding troughs, open pens for animal management, warehouses, silos, and equipment for cropping and harvesting forage maize.

\subsubsection{Detailed farming system characterization}

Of the six farms selected for detailed characterization, three belonged to the semi-specialized category (SS), the other three to the family-based category (FB). Their position in the groups distinguished by clustering is shown in Figure 2.3. Groups 2 and 4 were represented by one farm each, which were relatively intensive with stocking rates exceeding $1.25 \mathrm{LU} \mathrm{ha}^{-1}$ and milk production per cow around 4,300 kg lactation ${ }^{-1}$. These farms were denoted FBI and SSI, respectively. Medium-intensive (FBM and SSM) and extensive (FBE and SSE) farms with lower stocking rates and animal productivity represented groups 1 and 3. Although hired labour represented the main source of labour in the FBI farm, this farm matched the characteristics of the family-based category in terms of area, livestock and source of income, within the broad range of variation for these variables in the group (Tables 2.3 and 2.4). The SSI farm was smaller than the average of group 4 in terms of farm area and livestock 
Table 2.3. Means and coefficients of variation (CV, expressed as fraction) of variables describing the four groups of dairy farms in Marcos Castellanos, Michoacán, Mexico, found by PCA followed by AHCA.

\begin{tabular}{|c|c|c|c|c|c|c|c|c|}
\hline \multirow[t]{2}{*}{ Variable } & \multicolumn{2}{|c|}{$\begin{array}{c}\text { Group } 1 \\
\text { (29\%) }\end{array}$} & \multicolumn{2}{|c|}{$\begin{array}{c}\text { Group } 2 \\
\text { (42\%) }\end{array}$} & \multicolumn{2}{|c|}{$\begin{array}{c}\text { Group } 3 \\
\text { (11\%) }\end{array}$} & \multicolumn{2}{|c|}{$\begin{array}{c}\text { Group } 4 \\
\text { (18\%) }\end{array}$} \\
\hline & Mean & $\mathrm{CV}$ & Mean & $\mathrm{CV}$ & Mean & $\mathrm{CV}$ & Mean & $\mathrm{CV}$ \\
\hline Land owned (ha) & 12.0 & 1.1 & 14.5 & 1.6 & 139.6 & 0.3 & 25.8 & 1.0 \\
\hline Land rented (ha) & 14.8 & 1.1 & 15.4 & 1.3 & 42.0 & 1.0 & 78.3 & 0.7 \\
\hline Grazing land (ha) & 20.5 & 0.9 & 23.5 & 0.9 & 167.1 & 0.3 & 72.4 & 0.8 \\
\hline Livestock (LU) & 34.9 & 0.7 & 35.2 & 0.8 & 143.6 & 0.3 & 69.8 & 0.4 \\
\hline Infrastructure and equipment (Index) ${ }^{1}$ & 1.9 & 0.7 & 2.0 & 0.6 & 5.1 & 0.4 & 3.9 & 0.6 \\
\hline Off-farm income (Index) ${ }^{1}$ & 0.0 & - & 0.59 & 0.4 & 0.25 & 1.4 & 0.18 & 1.4 \\
\hline Hired labor (Labor-day $\left.\mathrm{y}^{-1}\right)^{2}$ & 56 & 2.2 & 166 & 1.7 & 905 & 0.5 & 281 & 0.9 \\
\hline Family labor (Labor-day $\left.\mathrm{y}^{-1}\right)^{2}$ & 772 & 0.6 & 1001 & 0.9 & 477 & 0.8 & 974 & 0.7 \\
\hline Feeding management (Index) ${ }^{1}$ & 14.3 & 0.3 & 15.7 & 0.4 & 16.3 & 0.6 & 14.7 & 0.3 \\
\hline Animal health management (Index) ${ }^{1}$ & 1.5 & 0.3 & 1.5 & 0.3 & 2.0 & 0.2 & 1.9 & 0.3 \\
\hline
\end{tabular}

${ }^{1}$ The procedures to calculate the indices are described in Table 2.1.

${ }^{2}$ One labor-day is equivalent to $8 \mathrm{~h}$ of work.

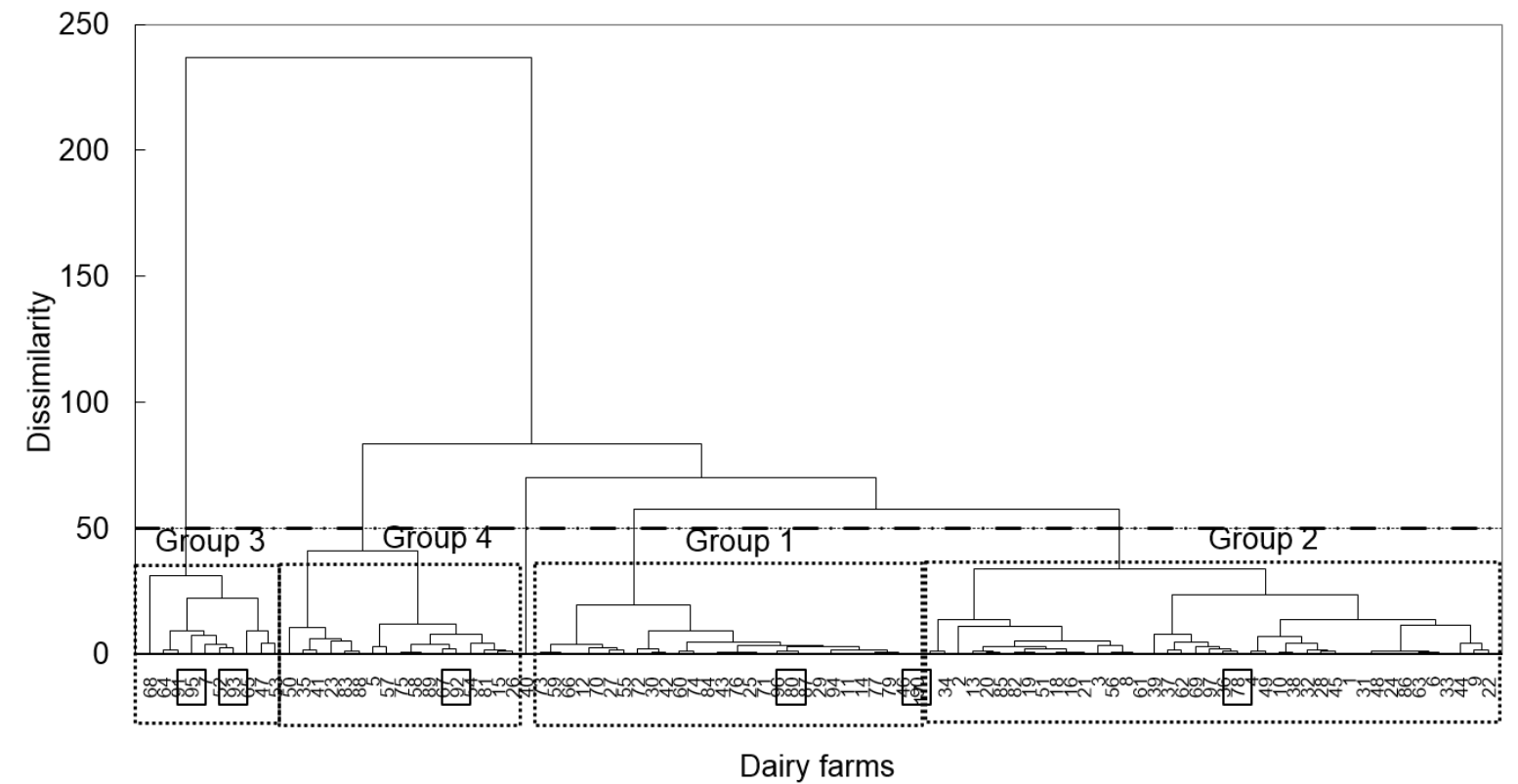

Figure 2.3. Dendrogram resulting from agglomerative hierarchical clustering of dairy farms in Marcos Castellanos, Michoacán, Mexico. The dotted line indicates the cutoff level used to distinguish groups and represents a total within-group inertia (sum of variances of the group components) of 51\%. The dotted squares delimit the groups. The solid squares on the X-axis represent the farms selected for detailed description. Farm 40, located between group 4 and group 1, was considered an outlier and excluded from further analysis. 
number; however, it had more infrastructure, equipment, and alternatives to feed its animals than farms in groups 1 and 2. Each farm is briefly described below, based on information included in Table 2.4.

Table 2.4. Characteristics of six dairy farms representing four groups identified in a farm typology for Marcos Castellanos, Michoacán, Mexico. Within each group FB denotes family-based and SS semi-specialized, according to the Mexican national farm classification. Additional letters I, M and E denote intensive, intermediate and extensive, respectively.

\begin{tabular}{|c|c|c|c|c|c|c|}
\hline \multirow{2}{*}{ Variable $^{1}$} & \multicolumn{2}{|c|}{ Group 1} & \multirow{2}{*}{$\begin{array}{c}\text { Group } 2 \\
\text { FBI }\end{array}$} & \multicolumn{2}{|c|}{ Group 3} & \multirow{2}{*}{$\begin{array}{c}\text { Group } 4 \\
\text { SSI }\end{array}$} \\
\hline & $\overline{\text { FBE }}$ & FBM & & SSE & SSM & \\
\hline \multicolumn{7}{|l|}{ Classification variables } \\
\hline $\begin{array}{l}\text { Land owned (ha) } \\
\text { nand }\end{array}$ & 0.0 & 11.2 & 23.6 & 95.1 & 101.0 & 12.3 \\
\hline Land rented (ha) & 57.9 & 35.5 & 0.0 & 0.0 & 31.8 & 11.3 \\
\hline Grazing land (ha) & 54.7 & 44.5 & 18.1 & 76.0 & 109.6 & 19.1 \\
\hline Livestock (LU) & 18.9 & 35.2 & 31.2 & 59.2 & 141.7 & 37.3 \\
\hline Infrastructure and equipment (Index) & 0.9 & 3.9 & 3.8 & 6.4 & 5.7 & 4.9 \\
\hline Off-farm income (Index) & 0.0 & 0.0 & 0.5 & 0.5 & 0.0 & 0.0 \\
\hline Hired labor (Labor-day $\mathrm{y}^{-1}$ ) & 0 & 185 & 387 & 1110 & 1208 & 1000 \\
\hline Family labor (Labor-day $\mathrm{y}^{-1}$ ) & 548 & 365 & 148 & 114 & 365 & 532 \\
\hline Feeding management (Index) & 18.6 & 20.6 & 23.2 & 19.6 & 25.3 & 22.2 \\
\hline Animal health management (Index) & 1.9 & 1.9 & 1.4 & 1.8 & 2.5 & 2.3 \\
\hline \multicolumn{7}{|l|}{ Derived variables } \\
\hline Total farm area (ha) & 57.9 & 46.7 & 23.6 & 95.1 & 132.8 & 23.6 \\
\hline Stocking rate ( $\left.\mathrm{LU} \mathrm{ha}^{-1}\right)$ & 0.33 & 0.75 & 1.31 & 0.62 & 1.05 & 1.57 \\
\hline Milking cows / Total cows ratio & 0.81 & 0.83 & 0.89 & 0.68 & 0.63 & 0.85 \\
\hline Proportion owned land & 0.00 & 0.24 & 1.00 & 1.00 & 0.76 & 0.52 \\
\hline Proportion rangeland & 0.94 & 0.95 & 0.77 & 0.80 & 0.83 & 0.81 \\
\hline Proportion family labor & 1.00 & $0.6 €$ & 0.28 & 0.09 & 0.23 & 0.35 \\
\hline Total labor per LU (Labor-day LU ${ }^{-1}$ ) & 29.0 & 15.6 & 17.1 & 20.7 & 11.1 & 41.1 \\
\hline \multicolumn{7}{|l|}{ Productivity } \\
\hline Milk volume (Mg farm $\left.{ }^{-1}\right)$ & 35.0 & 87.3 & 92.1 & 146.6 & 302.2 & 137.9 \\
\hline Milk per area $\left(\mathrm{kg} \mathrm{ha}^{-1}\right)$ & 605 & 1870 & 3903 & 1543 & 2276 & 5845 \\
\hline Milk yield $\left(\mathrm{kg} \mathrm{cow}^{-1} \text { lactation }^{-1}\right)^{2}$ & 2425 & 3061 & 4339 & 2936 & 2750 & 4290 \\
\hline Maize yield (Mg DM ha-1) & 10.3 & 16.0 & 16.5 & 7.7 & 16.3 & 7.4 \\
\hline \multicolumn{7}{|l|}{ Feeding strategy (fraction of ration DM) } \\
\hline Purchased concentrates & 0.40 & 0.37 & 0.53 & 0.34 & 0.29 & 0.33 \\
\hline Purchased forage & 0.06 & 0.10 & 0.10 & 0.20 & 0.00 & 0.29 \\
\hline On-farm maize forage & 0.05 & 0.27 & 0.21 & 0.18 & 0.50 & 0.16 \\
\hline On-farm grazing land & 0.49 & 0.27 & 0.16 & 0.27 & 0.21 & 0.22 \\
\hline
\end{tabular}

${ }^{1}$ The procedures to calculate the indices were described in Table 2.1.

${ }^{2}$ Estimated based on herd size and a lactation period of 305 days.

\subsubsection{Family-based extensive farm (FBE)}

Farm FBE rented land, but due to its small size (18.9 LU) grazing land and infrastructure was shared with another small farmer. The rented land was poorly accessible and infrastructure for milking, feeding and watering the animals was basic. Two family members milked the cows by hand. Milk production per cow was low (2425 kg cow $^{-1}$ lactation ${ }^{-1}$ ). Due to lack of infrastructure, poor accessibility of the land and low productivity, cows were milked only once daily during the seven 
months dry season. Maize forage was cultivated on 3.3 ha of rented cropland. Due to the harsh physiographic conditions of the cropland, with between 10 and 15\% of slope and 15\% coverage with rocks, not all cropland could be planted and cropping and harvesting forage maize could not be mechanized. These constraints resulted in low maize productivity (10.3 $\mathrm{Mg} \mathrm{DM} \mathrm{ha}^{-1}$ ). Maize was conserved as ground maize. The animal ration consisted to $46 \%$ of purchased feedstuffs, mainly concentrates.

\subsubsection{Family-based medium-intensive farm (FBM)}

Farm FBM comprised of 11.4 ha of own land, used as cropland (2.3 ha), grazing land (8.0 ha) including 2.9 ha of cultivated grassland sown to rhodes grass (Chloris gayana), and infrastructure and field edges (1.1 ha). The farmer rented 35.5 ha of rangeland, changing the location of rented land every year and occasionally sharing the rented area with another farmer. Infrastructure consisted of a watering place, a warehouse for feedstuff, and a small milking parlor equipped with a milking machine and individual feeding troughs. The farmer provided most of the labor. A part time worker was hired for milking, providing 34\% of the total labor. Milk production per cow was $3061 \mathrm{~kg} \mathrm{cow}^{-1}$ lactation $^{-1}$. Milking was done twice daily with a milking machine; the residual milk was extracted by hand at a time cost. During the rainy season, the cows grazed on restricted areas, while during the dry season the cows were allowed access to all grazing land. Supplementary feed consisting of concentrates and ground maize was provided during milking. During the dry season the cows were fed with maize silage produced on the farm or purchased conserved forage. The ration consisted to $47 \%$ of purchased feedstuffs, mainly concentrates. Forage maize seedbed preparation, seeding and harvesting was carried out by a contractor; the second fertilizer rate and all pesticides were applied by hand by the farmer. Although the FBM farm achieved high forage maize production (16.0 Mg DM ha ${ }^{-1}$ ), conserved forage was imported.

\subsubsection{Family-based intensive farm (FBI)}

The FBI farm achieved a relatively high milk production per cow (4339 $\mathrm{kg} \mathrm{cow}^{-1}$ lactation ${ }^{-1}$ ) by a feeding management based on a combination of on-farm feed resources from cropland (5.5 ha), rangeland (12.8 ha) and cultivated grassland sown to rhodes grass (5.3 ha), as well as imported concentrates. On-farm produced forage maize that was not used (51\%) was sold, resulting in a higher returns than from milk. Hired labour for animal management represented $72 \%$ of the total labor. Due to lack of technical skills twice a day milking was done by hand, even though the farm owned milking infrastructure. The low infrastructure and equipment index value of the FBI farm was caused by a lack of equipment for cropping forage maize. Maize forage productivity was high (16.5 Mg DM ha ${ }^{-1}$ ). The animal ration consisted to $63 \%$ of purchased feedstuffs, mainly concentrates. 


\subsubsection{Semi-specialized extensive farm (SSE)}

The SSE farm owned 95 ha of land: 11.6 ha cropland, 2.5 ha improved pasture sown to annual ryegrass (Lolium multiflorum), and 81 ha of rangeland. Three permanent workers took care of cows, calves and heifers, and cropped forage maize. Milking was done mechanically twice daily in a milking parlor. Productivity was ca. $3000 \mathrm{~kg}$ milk $\mathrm{cow}^{-1}$ lactation $^{-1}$. One of the permanent workers was responsible for maize forage production and temporary labour was hired for fertilizer and pesticide applications. The SSE farm owned part of the equipment for tillage and sowing, but the second fertilizer application and pesticide spraying was done by hand. Forage maize yield was low (7.7 Mg $\left.\mathrm{DM} \mathrm{ha}^{-1}\right)$. The animal ration consisted to $54 \%$ of purchased feedstuffs, both concentrates and forage.

\subsubsection{Semi-specialized medium-intensive farm (SSM)}

Farm SSM was characterized by good infrastructure and equipment consisting of two warehouses, a covered room for feeding and watering the cows, a milking parlor, individual and special pens for keeping bulls, sick animals, suckling and weaned calves, a machine shed, and a silo. The farm owned 23 ha of cropland, 53.3 ha of rangeland, and 10 ha of improved pasture sown to rhodes grass; 31.8 ha of rangeland were rented for replacement animals. Two permanent workers were responsible for animal management; hired labour comprised $77 \%$ of total labor. During the rainy season cows grazed the rangeland and received supplementary feed after milking (a mix of concentrates and ground maize) in a roofed space with individual troughs. Throughout the dry season the cows were kept on 2 ha of former cropland close to the farm buildings, which was sown to forage maize in the following rainy season. During the dry season the cows were fed twice daily with maize silage and a mix of concentrates and ground maize. The farm produced maize forage in excess of its requirements due to a large area of cropland and a high production level (16.3 $\left.\mathrm{Mg} \mathrm{DM} \mathrm{ha}^{-1}\right)$. Forage was conserved as silage and as ground maize; silage was used on-farm while part of the ground maize was sold. The farmer himself was in charge of the mechanized work for maize forage production, whereas hired workers carried out fertilizer application, weed and pest control, harvesting and processing. The ration consisted to $29 \%$ of purchased feedstuffs, mainly concentrates.

\subsubsection{Semi-specialized intensive farm (SSI)}

The SSI farm owned 14.3 ha of land and rented land for grazing (11.3 ha) and forage maize production (4.4 ha). The farm had infrastructure for milking, keeping animals, conserving forage, and storing feedstuff. The SSI farm owned a tractor with some implements for crop management. The farm was run by two hired workers and the owner. Cows were milked mechanically twice daily. Animal

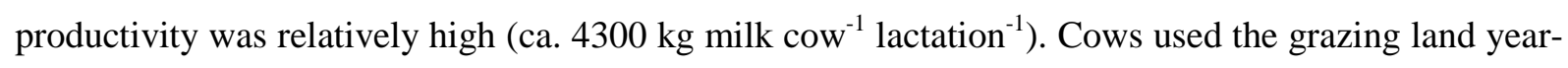
round. During milking, cows were fed individually with supplements. Throughout the dry season, they received additional feed: lucerne hay, sugar cane tips, or ryegrass hay. The farm family processed part 
of the milk into dairy products, which were commercialized on the regional market. Forage maize production was carried out by hired labour and conserved as ground maize; yield was low (7.4 Mg $\mathrm{DM} \mathrm{ha}^{-1}$ ). The ration consisted to $62 \%$ of purchased feedstuffs, both concentrates and forage.

\subsubsection{Economic performance}

Revenues, costs and margins per kg milk of the six farms are described in Figure 2.4 as a function of intensity of production, expressed as stocking rate. Revenues per kg milk were similar among farms, except for farm SSI which achieved about $25 \%$ higher revenue per kg milk than the others due to sale of processed milk. Total costs per kg milk decreased as production intensity increased from 0.33 to 1.05 LU ha ${ }^{-1}$ and then stabilized. Explicit costs varied among farms without a consistent pattern, and represented approximately $70 \%$ of total costs. The 30\% implicit costs were mainly caused by family labour (data not shown). Gross margins for FBE, FBM, SSM and SSI were similar, around 0.09 US\$ $\mathrm{kg}^{-1}$ milk. Farms FBI and SSE had negative gross margins of up to $0.09 \mathrm{US}_{\mathrm{kg}}{ }^{-1}$ milk. Net margins per kg milk were negative except for SSI which just broke even, and tended to increase with stocking rate (Figure 2.4). Differences in economic performance appeared to be more related to differences in production intensity than to the distinction between family-based and semi-specialized systems.

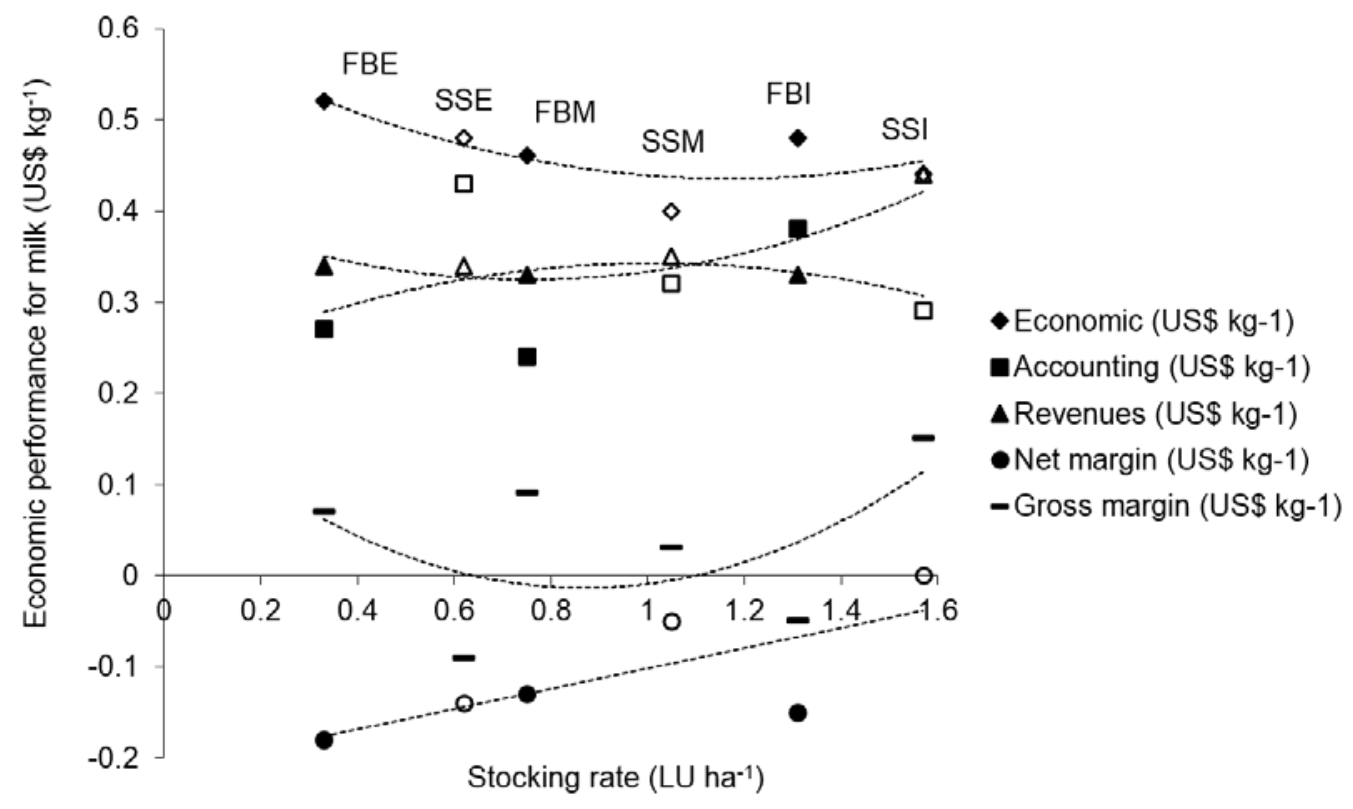

Figure 2.4. Total $(\bullet)$ and explicit costs $(\boldsymbol{\bullet})$, revenues $(\boldsymbol{\Delta})$, gross $(\boldsymbol{-})$ and net $(\bullet)$ margins per $\mathrm{kg}$ milk for family-based (FB) and semi-specialized (SS) dairy farms as a function of production intensity expressed in stocking rate $\left(\mathrm{LU} \mathrm{ha}{ }^{-1}\right)$. Additional letters $\mathrm{I}, \mathrm{M}$ and $\mathrm{E}$ denote intensive, intermediate and extensive, respectively (see text). Closed symbols indicate family-based farms; open symbols denote semi-specialized farms. 
Feed costs accounted for 50 to $70 \%$ of total costs, well exceeding hired labour cost (15-40\%) and other costs (8-19\%) (Table 2.5). The large share of feed costs in total costs was caused by the reliance on purchased forage and concentrates. Across the 6 farms the purchased fraction dry matter ranged from 29 to $63 \%$ of total ration dry matter (Table 2.4). As a result, costs of purchased feeds amounted to $59-89 \%$ of feed costs (Table 2.5 ). On-farm maize forage production costs varied widely among farms, ranging from 51 to $138 \mathrm{US} \$ \mathrm{Mg}^{-1} \mathrm{DM}$ for ground maize production and 56 to $163 \mathrm{US \$ \textrm {Mg } ^ { - 1 }}$ DM for silage production (Table 2.6). Before harvest, low costs per unit DM production were associated with low inputs (FBE, FBM) and/or high production levels (FBM, FBI, SSM). The high production costs of SSE were caused by large input costs (e.g. use of double fertilizer application at high doses) and low yields. Harvesting and processing constituted between $64 \%$ and $75 \%$ of total production costs, with greater variation among farms than between silage and ground maize (Table 2.6).

Table 2.5. Cost structure for milk production and feed ration as observed on 6 farms representing four groups in Marcos Castellanos, Michoacán, Mexico. FB denotes family-based and SS semi-specialized systems. Additional letters I, M and E denote intensive, intermediate and extensive, respectively (see text).

\begin{tabular}{|c|c|c|c|c|c|c|c|}
\hline \multirow{2}{*}{ Variable } & \multicolumn{2}{|c|}{ Group 1} & \multirow{2}{*}{$\begin{array}{l}\text { Group } 2 \\
\text { FBI }\end{array}$} & \multicolumn{2}{|c|}{ Group 3} & Group 4 & \multirow{2}{*}{ Mean } \\
\hline & FBE & FBM & & SSE & SSM & SSI & \\
\hline \multicolumn{8}{|c|}{ Milk production costs (US\$ kg-1 milk) } \\
\hline Feed & 0.26 & 0.25 & 0.30 & 0.33 & 0.25 & 0.21 & 0.27 \\
\hline Labor & 0.20 & 0.14 & 0.12 & 0.07 & 0.06 & 0.16 & 0.13 \\
\hline Other & 0.04 & 0.05 & 0.05 & 0.07 & 0.07 & 0.06 & 0.06 \\
\hline $\begin{array}{l}\text { Total milk production } \\
\text { costs }\end{array}$ & 0.50 & 0.44 & 0.47 & 0.47 & 0.38 & 0.43 & 0.45 \\
\hline
\end{tabular}

Feed ration costs (US\$ kg-1 milk)

\begin{tabular}{|c|c|c|c|c|c|c|c|}
\hline Concentrate & 0.21 & 0.14 & 0.21 & 0.18 & 0.17 & 0.15 & 0.18 \\
\hline Forage purchased & 0.02 & 0.01 & 0.02 & 0.07 & 0 & 0.03 & 0.03 \\
\hline Maize forage produced & 0.01 & 0.08 & 0.06 & 0.07 & 0.07 & 0.02 & 0.05 \\
\hline Grazing land (own) & 0 & 0 & 0.01 & 0.01 & 0.01 & 0.01 & 0.01 \\
\hline Grazing land (rented) & 0.02 & 0.02 & 0 & 0 & 0 & 0 & 0.01 \\
\hline Total feed costs & 0.26 & 0.25 & 0.30 & 0.33 & 0.25 & 0.21 & 0.27 \\
\hline
\end{tabular}


Table 2.6. Cost structure (US\$ $\left.\mathrm{Mg}^{-1} \mathrm{DM}\right)$ and yields $\left(\mathrm{Mg} \mathrm{DM} \mathrm{ha}{ }^{-1}\right)$ of ground maize and maize silage production as observed on farms belonging to one of 6 farm types in Marcos Castellanos, Michoacán, Mexico. FB denotes family-based and SS semi-specialized systems. Additional letters I, M and E denote intensive, intermediate and extensive, respectively (see text).

\begin{tabular}{|c|c|c|c|c|c|}
\hline \multirow{2}{*}{ Item } & Group 1 & Group 2 & Group 3 & Group 4 & \multirow{2}{*}{ Mean } \\
\hline & FBE $\quad$ FBM & FBI & $\overline{\text { SSM }}$ & SSI & \\
\hline
\end{tabular}

$\underline{\text { Overall costs }}$

Total ground maize

$\begin{array}{rrrrrrr}99 & - & - & - & 160 & 268 & 181 \\ - & 108 & 145 & 315 & 128 & - & 173\end{array}$

Total silage maize

\section{$\underline{\text { Cropping costs }}$}

\begin{tabular}{|c|c|c|c|c|c|c|c|}
\hline Labor + machinery & 10 & 11 & 11 & 35 & 6 & 22 & 16 \\
\hline Fertilizers & 5 & 12 & 17 & 52 & 16 & 33 & 21 \\
\hline Pesticides & 3 & 7 & 8 & 18 & 6 & 9 & 9 \\
\hline Other & 13 & 3 & 5 & 7 & 12 & 13 & 11 \\
\hline Total cropping & 32 & 33 & 41 & 113 & 40 & 77 & 56 \\
\hline \multicolumn{8}{|c|}{ Conservation costs as ground maize } \\
\hline Harvesting & 51 & - & - & - & 82 & 138 & 90 \\
\hline Grounding & 16 & - & - & - & 38 & 53 & 35 \\
\hline Total ground conservation & 67 & - & - & - & 120 & 191 & 125 \\
\hline \multicolumn{8}{|c|}{ Conservation costs as silage maize } \\
\hline Harvesting & - & 56 & 75 & 163 & 66 & - & 90 \\
\hline Ensiling & - & 19 & 29 & 39 & 22 & - & 27 \\
\hline Total silage conservation & - & 75 & 104 & 202 & 88 & - & 117 \\
\hline \multicolumn{8}{|l|}{ Maize yield off-field } \\
\hline & 10.3 & 16.0 & 16.5 & 7.7 & 16.3 & 7.4 & 12.4 \\
\hline
\end{tabular}

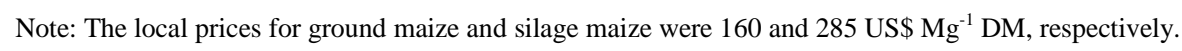




\subsubsection{Labour and land productivity}

Labour productivity reached a maximum of ca. $190 \mathrm{~kg}$ milk per labor-day at a stocking rate of about 1 LU ha ${ }^{-1}$ (Figure 2.5a). This was the result of close to linear increasing animal productivity (kg milk $\mathrm{cow}^{-1}$ lactaction ${ }^{-1}$; Figure 2.5b), and labour requirements for animal management (labor-days LU ${ }^{-1}$ ) which decreased up to $1 \mathrm{LU} \mathrm{ha}^{-1}$ and increased at higher stocking rates (Figure 2.5c).
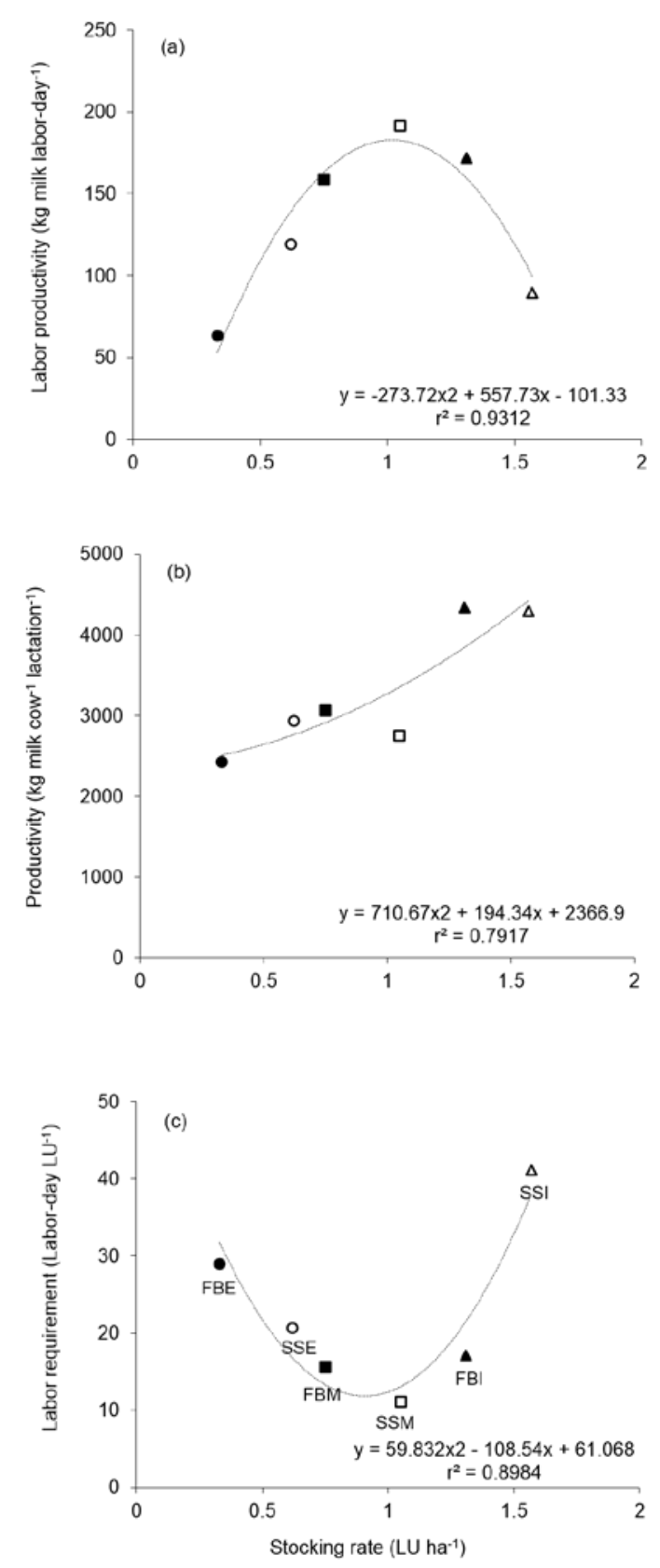

Figure 2.5. (a) Labour productivity (kg milk labor-day ${ }^{-1}$ ), (b) animal productivity (kg milk cow ${ }^{-1}$ lactation $^{-1}$ ), and (c) labor requirement (labour-day $\mathrm{LU}^{-1}$ ) as a function of production intensity expressed in stocking rate $\left(\mathrm{LU} \mathrm{ha}{ }^{-1}\right)$ for six dairy farms in north-west Michoacán, Mexico. Closed symbols indicate family-based systems; open symbols denote semi-specialized farms. Dashed lines represent quadratic trends. 
The return to labour based on gross margin was substantially less than the opportunity cost of labour for all farms and was less than the 'minimum required salary' for all farms except SSI (Figure 2.6). For SSE return to labour was negative. This implies that farm incomes were insufficient to cover the primary needs of an average family. Return to labour was strongly related to total feed cost (Table 2.5; Figure 2.6), revealing the importance of cost reduction.

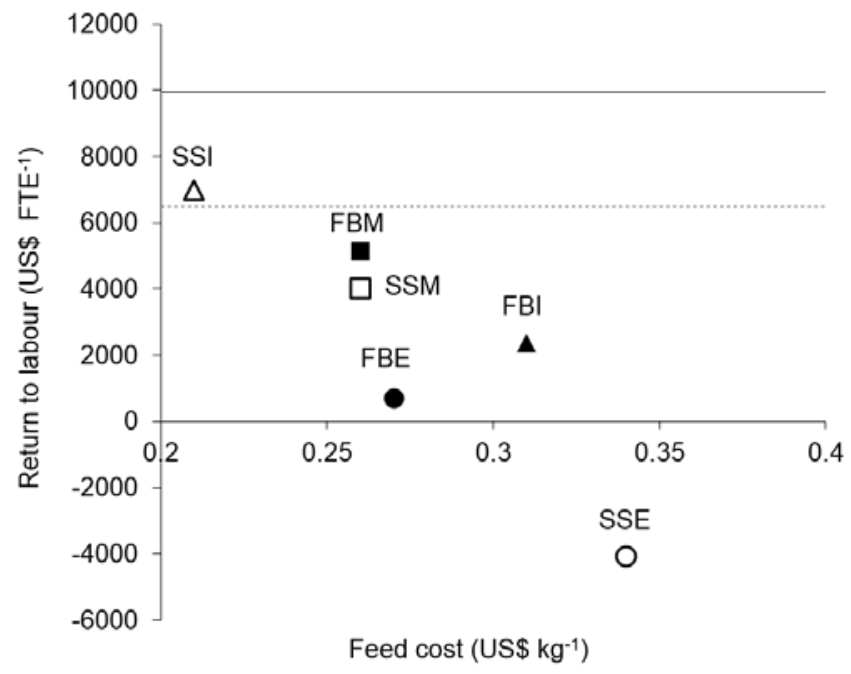

Figure 2.6. Relationship between feed costs (US $\$ \mathrm{~kg}^{-1}$ ) and return to labour (US $\$ \mathrm{FTE}^{-1}$ ) for six dairy farms in north-west Michoacán, Mexico. Also shown are labour opportunity cost (drawn line) and required minimum salary (dotted line). Return to labour was calculated as annual gross margin per unit of full time equivalent assuming an $8 \mathrm{~h}$ workday. The 'required minimum salary' represents the annual amount of money needed to cover social, cultural and educational necessities for an average family, and is published by the local government. Closed symbols indicate family-based farms; open symbols denote semi-specialized farms.

\subsection{Discussion}

The farm survey revealed major variation among the dairy farms in area, livestock units, amount of hired labour, and infrastructure and equipment, but surprising uniformity in animal health management and feeding strategies (Table 2.1). The indicator value for animal health management revealed practices well below what was considered good farming practice. The survey also revealed that on all farms feeding management relied on a limited number of feed sources. More detailed analysis showed that on 5 out of 6 farms around half or more of the ration dry matter consisted of bought feedstuffs (Table 2.4). While Amendola (2002) reported positive net margins of 3.2 to $4.5 \$ \mathrm{ct} \mathrm{kg}^{-1}$ milk for family-based and semi-specialized farms around the year 2000, our analyses revealed that all farms 
had negative profitability, even those that appeared more affluent during the investigation. A reason for this change in profitability is quite likely the differential change in prices of outputs and inputs. Between 2007 and 2012 the milk price increased by 27\% while average prices of concentrates increased by $55 \%$. The farms in the study region have persisted because farmers accepted undervaluation of their own labour input and relied partly on external sources of income to support their lifestyle. In view of these results it is not surprising that even in this major dairy region of Michoacán young people continue to migrate to the US rather than build a livelihood on their farms.

The distinction between family-based and semi-specialized farm types of the Mexican national dairy systems classification can be denoted as a conceptual household typology created by experts (cf. Amendola, 2002; Pacini et al., 2014). The statistical farm typology based on resource endowment in this study also revealed family-based (groups 1 and 2) and semi-specialized (groups 3 and 4) farm types and thus confirmed the broad conceptual classes. As shown in the detailed farm analyses, however, differences in animal productivity $\left({\mathrm{kg} \text { milk } \operatorname{cow}^{-1} \text { lactation }}^{-1}\right)$, labour productivity (kg milk labor-day ${ }^{-1}$ ), and return to labour (US $\$$ labor- day $^{-1}$ ) did not follow the resource endowment-based typology (Figures 2.5 and 2.6), and on the contrary showed strong overlap between family-based and semi-specialized types. Animal and labour productivity were explained by differences in stocking rates among farms (Figure 2.5). Return to labour depended on farm-specific revenues and particularly on farm-specific costs, which were not clearly related to farm type or stocking rate (Figures 2.4 and 2.6, Tables 2.5 and 2.6). Processing milk to fetch a good price, high forage maize yields and low costs of external input for feed or cropping all contributed to favourable productivity values. Thus, to capture local farm diversity to enable targeting on-farm changes as was the aim of this study and to support governmental financial support programs, the resource oriented survey should be extended with information on intensity of crop and animal production. In the current study, such information would be provided by variables describing the share of external feed in the ration and proxies of internal resource use, e.g. reflected in crop and milk yields. Which variables should be selected for specific studies will need to be determined in a preliminary assessment of a limited number of farms to generate hypotheses on key explanatory variables. In a farm typology for banana cropping systems redesign Blazy et al. (2009) included agronomical, economic and environmental performance indicators in addition to farming context variables. More common in the literature seem studies that put emphasis on resource endowment over production intensity (e.g. Bidogeza et al., 2009; Tittonell et al., 2005, 2010; Righi et al., 2011; Franke et al., 2014; Pacini et al., 2014) because the interest is in representativeness of a selection of farms, in recommendation domains for specific novel technology, or in diversity in itself, rather than in targeting customizing on-farm innovations. This emphasizes the need to be specific about the purpose of describing farm diversity.

Strong points of family farming that are commonly mentioned include flexibility, particularly in terms of labour, low costs and use of internal resources (Herrero et al., 2010). Our results suggest that on the 


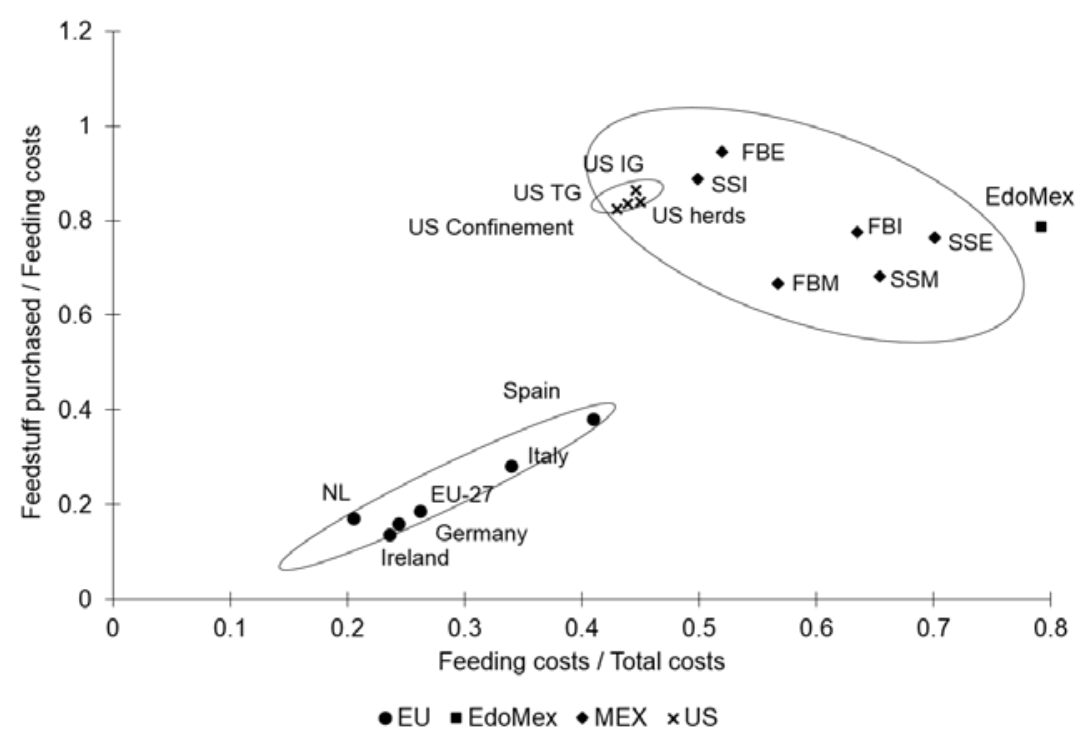

Figure 2.7. Comparison of the feeding costs impact in dairy farm systems of Marcos Castellanos, Michoacán (FBE, FBM, FBI, SSE, SSM, and SSI) and dairy systems of the United States, Estado de México (EdoMex), and European Union members. The United States dairy farms represent the averages for confinement feeding $(n=25)$, traditional grazing (TG, $n=52)$, intensive grazing (IG, $n=19)$, and all systems $(n=96)$ (Winsten et al., 2000). The information used for Estado de México implies the average of three peasant dairy production systems (Espinoza-Ortega et al., 2005).The information used for the European Union members represents the average for all dairy farms (European Commission, 2011).

farms in the study region cost reduction and use of internal resources have been largely ignored as strategic options. As shown in Figure 2.7 the farm strategies in the study region resemble those of North America by their strong reliance on external inputs, and even surpass the North American systems in terms of the share of feed costs in total costs. In contrast, dairy systems in Spain, the country of origin of the Mexican systems, resemble those in temperate Europe and in New Zealand, which rely on on-farm roughage production. Although Figure 2.7 needs to be interpreted with caution as it compares (sub-)national averages with individual farms, it clearly points to the importance of considering contextual solutions instead of copying modernization strategies developed elsewhere (cf. Van der Ploeg et al., 2007).

Enhancing on-farm forage production should consider both energy-rich and protein-rich feed components to arrive at balanced rations. Maize biomass yields on the study farms ranged from 7.4 $\mathrm{Mg} \mathrm{ha}^{-1}$ to $16.5 \mathrm{Mg} \mathrm{ha}^{-1}$. Thus, scope seems to exist for improvement of energy-rich feed using existing technologies, particularly when fine-tuned in terms of resource use efficiency. An obvious option is to use manure as a source of crop nutrients by feeding the cows in corrals during the dry season, which during the rainy season are used for maize production. In this way, manure produced during the dry season can be used for forage production, reducing the costs of purchased fertilizers. At 
the same time, manure will contribute to improving long-term soil fertility. This option would require a change in the local perception of manure, which is currently considered a waste product. Taking average costs of production into account and based on prices of 2010, an extra ton of silage constitutes a reduction in external feed costs of 219 US\$; per ton of ground maize the cost reduction is 78 US\$. Evaluation of combinations of maize and protein-rich feed crops (e.g. Garduño-Castro et al., 2009) will reveal to which extent farms can achieve self-reliance in feed.

Animal productivity and herd management constitute further points for farm improvement by increasing current production levels of 2.4-4.3 $\mathrm{Mg} \mathrm{cow}^{-1}$ lactation $^{-1}$. In addition to fine-tuning feeding to animal requirements, the question is whether the Holstein Friesian breed that is most prevalent in the area is the most efficient under the prevailing climatic and feed availability conditions. Our results also showed (cf. Figure 2.4; Figure 2.5) that increasing production per animal should not become a goal in itself, but should be seen as a means of optimizing relevant performance characteristics such as labour productivity or return to labour. Such strategic changes require a more systemic perspective of dairy farming in the region. Points in case are the perception of manure as a waste product, the extension message focused on increasing animal productivity, and the use of intensive north American systems as prototypes of good farming pratice.

\subsection{Conclusions}

Family farms in a dairy region in Mexico were classified into 4 types, characterized by differences in herd size, land area, land ownership and amount of labour. The types showed strong resemblance to structural variables of the Family-based and Semi-specialized classes, which are used in Mexico. The types did not explain differences in animal productivity and labour productivity, which appeared related stocking rate. Intermediate stocking rates resulted in intermediate animal productivity but in highest labour productivity. Return to labour was strongly related to cost of feed. The results indicate that not only resource-endowment but also managerial and entrepreneurial characteristics need to be considered when designing on-farm innovations.

Return to labour was mostly lower than required for family sustainance, revealing a major rural development issue despite generally increasing wealth levels in Mexico. Various options were identified for closing the gap between the actual farm performance and the farm potential as defined by farm structure. They all involve rethinking of the intensification paradigm, which currently strongly resembles that of North America. Such rethinking should depart from the strong points of familybased farming: a systemic perspective, low costs and labour flexibility, and as such can borrow ideas from agro-ecological thinking and ecological intensification as a scientific paradigm. 


\subsection{Acknowledgements}

This project was funded by the European Union, Project INCO CT-2006-032387.We thank the dairy farmers of Marcos Castellanos for their cooperation and willingness of being part of this project, especially Arturo Padilla, Daniel Chávez, Everardo Haro, Filiberto García, Honorato González, and José Luis Orozco. We are grateful to our colleagues in the research team: D. Valentina Mariscal Aguayo, Martha P. Perales Rivas, Ramés Salcedo Vaca, Máximino Huerta Bravo, Luis Humberto Valencia Chávez, Efrén Trujillo López, Isela J. López Herrera, and Heriberto Estrella Quintero.

\subsection{References}

Amendola, R.D., 2002. A dairy system based on forages and gazing in temperate Mexico. Ph.D. dissertation. Wageningen University, The Netherlands.

Andersen, E., Elbersen, B., Godeschalk, F., and Verhoog, D., 2007. Farm management indicators and farm typologies as a basis for assessments in a changing policy environment. Journal of Environmental Management 82: 353 - 362.

Bidogeza, J.C., Berentsen, P.B.M., De Graaff, J., and Oude Lansink, A.G.J.M., 2009. A typology of farm households for the Umutara Province in Rwanda. Food Security 1: 321 - 335.

Blazy, J. M., Ozier-Lafontaine, H., Dorè, T., Thomas, A. and Wery, J., 2009. A methodological framework that accounts for farm diversity in the prototyping of crop management systems. Application to banana-based systems in Guadeloupe. Agricultural Systems 101: 30 - 41.

Carbaugh, R.J., 2006. Contemporary economics: An applications approach. $4^{\text {th }}$ Ed. Thompson Southwester, Ohio, USA. 464 p.

Dogliotti, S., García M.C., Peluffo, S., Dieste, J.P., Pedemonte, A.J., Bacigalupe, G.F., Scarlato, M., Alliaume, F., Alvarez, J., Chiappe, M., and Rossing, W.A.H., 2014. Co-innovation of family farm systems: a systems approach to sustainable agriculture. Agricultural Systems 126: 76 86.

European Comission, 2011. EU dairy farms report 2011. Directorate-General for Agriculture and Rural Development.

FAO (Food Agriculture Organization), 2011. FAOSTAT Accessed January 14, 2012 at: http://faostat.fao.org/.

Franke, A.C., van den Brand, G.J., and Giller, K.E., 2014. Which farmers benefit most from sustainable intensification? An ex-ante impact assessment of expanding grain legume production in Malawi. European Journal of Agronomy 58: 28 - 38.

Garduño-Castro, Y., Espinoza-Ortega, A., González-Esquivel, C.E., Mateo-Salazar, B., and ArriagaJordán C.M., 2009. Intercropped oats (Avena sativa) - common vetch (Vicia sativa) silage in 
the dry season for small-scale dairy systems in the Highlands of Central Mexico. Tropical Animal Health and Production 41: 827 - 834.

Gaspar, P., Escribano,M., Mesías, F. J., Rodriguez de Ledesma, A., and Pulido, F., 2008. Sheep farms in the Spanish rangelands (dehesas): typologies according to livestock management and economic indicators. Small Ruminant Research 74: 52 - 63.

González, L., 1992. Pueblo en vilo. $1^{\text {st }}$ Ed. Fondo de Cultura Económica, México. 349 p.

Herrero, M., Thorton, P.K., Notenbaert, A.M., Wood, S., Msangi, S., Freeman, H.A., Bossio, D., Dixon, J., Peters, M., van de Steeg, J., Lyman, J., Rao, P.P., Macmillan, S., Gerard, B., McDermott, J., Seré, C., and Rosegrant, M., 2010. Smart investments in sustainable food production: Revisiting mixed crop-livestock systems. Science 327: 822 - 825.

Hunter, L.M., Murray, S., and Riosmena, F., 2013. Rainfall patterns and U.S. migration from rural Mexico. International Migration Review 47: 874 - 909.

Köbrich, C., Rehman, T, and Khan, M., 2003. Typification of farming systems for constructing representative farm models: two illustrations of the application of multi-variate analyses in Chile and Pakistan. Agricultural Systems 76: 141 - 157.

OECD, 2006. Agricultural and fisheries policies in Mexico: Recent achievements, continuing the reform agenda. Organizatin for Economic Co-operation and Development, doi 10.1787/9789264030251-en.

Pacini, G.C., Colucci, D., Baudron, F., Righi, E., Corbeels, M.,Tittonell, P., and Stefanini, F.M., 2014. Combining multi-dimensional scaling and cluster analysis to describe the diversity of rural households. Experimental Agriculture 50: 376 - 397.

Righi, E., Dogliotti, S., Stefanini, F.M., and Pacini, G.C., 2011. Capturing farm diversity at regional level to up-scale farm level impact assessment of sustainable development options. Agriculture, Ecosystems and Environment 142: 63 - 74.

SAGARPA, 2007. Producción de leche. Secretaría de Agricultura, Ganadería, Desarrollo Rural, Pesca y Alimentación. http://w4.siap.gob.mx/sispro/portales/pecuarios/lechebovino.

SAGARPA, 2011. Boletín de Leche: Julio-Septiembre. Secretaría de Agricultura, Ganadería, Desarrollo Rural, Pesca y Alimentación. $<$ http://www.siap.gob.mx/index.php?option=com_content\&view=article\&id=51\&Itemid=38 $1>$.

SAGARPA, 2012. Leche bovino, leche caprino y huevo: Producción, precio y valor 2010. Secretaría de Agricultura, Ganadería, Desarrollo Rural, Pesca y Alimentación. http://www.siap.gob.mx/index.php?option.

SEMARNAT, 2003. Elaboración de diagnóstico y plan de manejo en la microcuenca San José de Gracia, Municipio de Marcos Castellanos, Michoacán. Secretaría de Medio Ambiente y Recursos Naturales, Michoacán, Mexico. 
Tittonell, P., Vanlauwe, B., Leffelaar, P.A., Rowe, E.C. and Giller, K.E., 2005. Exploring diversity in soil fertility management of smallholder farms in western Kenya: I. Heterogeneity at region and farm scale. Agriculture, Ecosystems and Environment 110: 149 - 165.

Tittonell, P., Muriuki, A., Shepherd, K.D., Mugendi, D., Kaizzi, K.C., Okeyo, J., Verchot, L., Coe, R., and Vanlauwe, B., 2010. The diversity of rural livelihoods and their influence on soil fertility in agricultural systems of East Africa-A typology of smallholder farms. Agricultural Systems 103: 83 - 97.

Van der Ploeg, J.D., 2003. The Virtual Farmer: past, presence and future of the Dutch peasantry, Royal Van Gorcum, Assen.

Van der Ploeg, J.D, Groot, J.C.J, Verhoeven, F.P.M, and Lantinga, E.A., 2007. Interpretation of results of on-farm experiments: slurry nitrogen recovery on grassland as affected by slurry quality and application technique. 2. A sociological analysis. NJAS-Wageningen Journal of Life Sciences 54: $255-268$.

Villareal, A., and Hamilton, E.R., 2012. Rush to the border? Market liberalization and urban- and rural-origin internal migration in Mexico. Social Science Research 41: 1275 - 1291.

Wattiaux, M., Blazek, J., and de Jesús Olmos Colmenero, J., 2012. Bird’s eye view of the Mexican dairy industry and on-the-ground assessment of production systems in the highlands (Los Altos) of Jalisco, Mexico. Babcock Institute Discussion paper no. 2012-2. 


\section{Chapter 3: Resource use efficiency and farm productivity gaps of smallholder dairy farming in North-west Michoacán, Mexico}

José Cortez-Arriola, Jeroen C.J. Groot, Ricardo D. Améndola Massiotti, Johannes M.S. Scholberg, D. Valentina Mariscal Aguayo, Pablo Tittonell, Walter A.H. Rossing. 


\begin{abstract}
Smallholder dairy farms that intensify production risk resource degradation and increased dependence on external feeds and fertilizers due to lack of knowledge and appropriate technology, which undermines farm productivity and profitability. Here we analyze underlying causes at farm level of such process through an integrated analysis at the farm scale by assessing current resource use efficiency for grazing-based dairy farming systems representative of NW Michoacán, Mexico. Wholefarm yield gaps were quantified by comparing current farms to virtual reference farms that have the same farm surface area but improved farm management. Productivity of reference farms was calculated by assuming best crop production practices (as observed within the set of case study farms) and improved herd management. Three family-based (FB) and three semi-specialized (SS) dairy systems spanning three levels of intensification in terms of density of livestock units (LU): extensive (E, <0.8 LU ha ${ }^{-1}$ ), medium-intensive ( $\mathrm{M}$, between 0.8 and 1.2 LU ha ${ }^{-1}$ ), and intensive (I, >1.2 LU ha ${ }^{-1}$ ) were monitored during one year (rainy and dry seasons) to assess productivity and resource use efficiencies. Milk production was generally low and variable (2.2-4.3 $\mathrm{Mg}$ milk cow $^{-1}$ lactaction $^{-1}$, and 0.6-5.8 $\mathrm{Mg} \mathrm{ha}^{-1}$ ) due to high incidence of mastitis, a large fraction of non-productive animals in the herd and inefficient reproduction management. During the dry season, grazing areas provided insufficient metabolizable energy, and milk production was sustained through increased use of concentrates (from $310 \mathrm{~g} \mathrm{~kg}^{-1} \mathrm{DMI}$ in rainy season to $454 \mathrm{~g} \mathrm{~kg}^{-1} \mathrm{DMI}^{-1}$ in dry season of the herd) and conserved forage. All farms had positive nitrogen, phosphorus and potassium balances, averaging $75 \pm 16,15 \pm 6$, and $19 \pm 6 \mathrm{~kg} \mathrm{ha}^{-1}$, respectively. Nutrients in animal excreta were mostly not recycled on the farms but lost to the environment, and nutrient surpluses increased with livestock density. The reference farms exhibited an attainable milk yield of $2.7 \mathrm{Mg} \mathrm{ha}^{-1}$ on the basis of full feed self-supply, and 4.2 $\mathrm{Mg} \mathrm{ha}^{-1}$ when the crude protein limitation in the ration was lifted. Compared to the reference farm actual milk yields were on average $78.4 \%$ lower on FB farms and 57.9\% lower on SS farms. The underlying causes of the farm yield gap differed between farms and were due to sub-optimal areas of forage maize, low forage and forage maize productivity and deficient herd management. We conclude that the farm yield gap analysis was effective in identifying the major shortcomings in management of the dairy farming systems and enabled formulation of change avenues for farm reconfiguration focusing on combined improvements in crop, feed and herd management and recycling of nutrients through manure management.
\end{abstract}

Keywords: Farm yield gap; farming intensity; herd structure; milk production; external dependence; nutrient balances.

Published in Agricultural Systems, 2014, 126: 15-24. Doi: 10.1016/j.agsy.2013.11.001. 


\subsection{Introduction}

Although smallholder farms produce a large share of the world's food supply and their production systems could potentially be diverse and sustainable, market and policy developments force them to intensify their production in order to compete with larger specialized farms (Kiers et al., 2009; Herrero et al., 2010). This often leads to an 'intensification-trap': in order to increase productivity small farmers intensify their production systems by increasing livestock density and inputs, but inadequate management results in larger nutrient surpluses or losses, farm resource degradation and strong dependence on external feeds and fertilizers.

The intensification trajectories of dairy farms in the northwest of Michoacán (Mexico) are a point in case. In this region where dairy production is an important economic activity, nutrient surpluses from livestock systems resulting in nutrient runoff and leaching are considered to be a major cause of negative environmental impacts on the 'Lerma - Chapala' basin. In Lake Chapala, the largest fresh water lake of Mexico, high concentration of $\mathrm{N}$ and $\mathrm{P}$ compounds (2.23 and $0.57 \mathrm{mg} \mathrm{l}^{-1}$, respectively) hamper the use of water resources for human consumption and irrigation (Silva et al., 2002; Ramírez et al., 2007). In the lowest part of the basin, continuous use of saline groundwater has increased the salinity and sodicity of the soil, limiting crop production and impacting soil management (Silva-García et al., 2006).

In addition to these environmental impacts, profitability of local production systems is cause for concern, mainly related to the high feed costs and the low milk productivity in the systems (EspinozaOrtega et al., 2005; Cortez-Arriola et al., 2015). Most livestock feeding systems in Mexico depend on the use of concentrates, conserved forage, and grazing land. In Mexico forage production during late spring and summer (the rainy season in most of the country) contributes between 60 and $79 \%$ to the total annual forage production (Améndola et al., 2005; Martínez et al., 2008; Sosa et al., 2008). Farmers address potential periodic forage shortages via the use of largely imported conserved forage (silage, hay and stover) or concentrates (Améndola et al., 2005; Cortez-Arriola et al., 2015). However, these options increase the dependence on external feed resources: $70 \%$ of the ration and represents up to $90 \%$ of the feeding costs. As a consequence, farm profitability is reduced (Espinoza-Ortega et al., 2005; Cortez-Arriola et al., 2015). On the other hand, animal productivity is a key variable to enhance the milk production in Mexico and the profitability of farming. In the period from 2004 to 2010 the average production was only $1.65 \mathrm{Mg}$ milk cow${ }^{-1}$ lactation $^{-1}$ (SAGARPA, 2011). In contrast, in The Netherlands and Italy where feeding is mainly based on own forage production with low contribution from external inputs in feeding costs (ca. 18\% of the total costs) production levels were 7.6 and 6.7 Mg milk cow ${ }^{-1}$ lactation $^{-1}$ (European Commission, 2011).

Efforts to develop more sustainable intensification trajectories may benefit from interventions based on yield gap analysis at the farming system level. To diagnose differences in performance among 
farms that operate under similar climatic conditions and natural resource availability, farm yield gap analysis is relevant to identify the most limiting and reducing factors that determine the yields and to find adjusted practices that could contribute to closing the gaps. Usually, yield gap analyses are conducted to determine differences between attainable and actual crop yields in cropping systems (Bhatia et al., 2006; Nin-Pratt et al., 2010; Van Ittersum et al., 2013). To narrow the gap, field crop production practices such as use of fertilizers, establishment of irrigation systems, and genetic improvements may then be proposed. In more complex agro-ecosystems such as mixed crop-livestock systems, a large farm yield gap can originate from shortcomings related to farm design, resource allocation and tactical planning. The resulting imbalances between feed supply and herd size combined with lack of effective herd management practices thus may hamper optimal use of forage resources and prevent farmers from attaining the production potential of livestock.

Here, we present a method to diagnose farming systems by constructing a virtual farm based on best existing local practices and use this as a reference to assess the farm yield gap and the contribution of constraints in the various sub-systems. We quantitatively analyze six dairy farms that represent the variation of dairy farming in the region of Marcos Castellanos, Michoacán, Mexico (Cortez-Arriola et al., 2015). Furthermore, we assess how farm management affects annual metabolic energy (ME), crude protein (CP), and $\mathrm{N}, \mathrm{P}$, and $\mathrm{K}$ balances. The objectives of this paper are: a) to quantify the gap between attainable and current farm milk yields taking a whole farm perspective, b) to diagnose the major factors that limit productivity of dairy farming systems in NW Michoacán; and c) to analyze how management affects farm gate nutrient balances and use efficiency of nutrients.

\subsection{Material and Methods}

\subsubsection{Case study region}

The municipality of Marcos Castellanos is located in the North-west of Michoacán, Mexico, (19 northern latitude and $103^{\circ}$ west longitude) at altitudes between 1,500 and 2,400 meters above sea level. According to the classification of Mexican hydrological regions it is located in the upper part of the 'Lerma - Chapala' basin, in the sub-basin 'Chapala', and in the micro-basin 'San José de Gracia'. The area of the municipality is 23,285 ha, representing $0.39 \%$ of the State; $86 \%$ of the area is grazing land (mainly native rangeland) and $12 \%$ is cropland, mostly used for forage maize production (Secretaría de Gobierno, 2010). The climate is classified as temperate with one main rainy season between June and October. Overall precipitation and temperature averages are $798 \mathrm{~mm}$ and $18.9^{\circ} \mathrm{C}$, respectively. Chromic and pellic Vertisols are the dominant soil type, in associations with Luvisols, Inceptisols, Phaeozems, and Andosols (SEMARNAT, 2003). The physiography is constituted by slightly sloping hills ending in ravines, and small almost flat areas. Thorny forest is the dominant type of vegetation, followed in importance by broadleaf forest (SAGDER, 2000). 


\subsubsection{Selection of farms representative of regional farming systems}

During 2007 a survey was carried out in the region, which was used to develop a farm typology presented elsewhere (Cortez-Arriola et al., 2015). From the total of 630 farms listed in the census of the regional association of dairy farmers, $14.6 \%$ were randomly selected and interviewed. Multivariate analysis of the survey data resulted in six main farm types, distinguished by the use of family versus hired labor and the intensity of production, in particular cattle densities. Based on these farm types and the national Mexican dairy farm classification (FIRA, 1997; SAGARPA, 2000; Amendola, 2002), six farms were selected for more detailed study. These farms are being referred to as family-based (FBx) or semi-specialized (SSx), where $\mathrm{x}$ describes the intensification level based on livestock density as $\mathrm{E}$ (extensive, $<0.8 \mathrm{LU} \mathrm{ha}^{-1}$ ), M (medium-intensive, between 0.8 and $1.2 \mathrm{LU} \mathrm{ha}^{-1}$ ) or I (intensive, $>1.2 \mathrm{LU}$ $\mathrm{ha}^{-1}$ ) (Table 3.1).

\subsubsection{Farm characterization}

In order to characterize each individual farm, close monitoring of system management and agroecological parameters took place between July 2009 and June 2010. At the crop subsystem level, information was collected on forage production, quality, utilization, inputs, and production costs. At

Table 3.1. Farm size, livestock, livestock density and composition, milk production and labor characteristics of six dairy farms of Marcos Castellanos, Michoacán, Mexico, and of the reference farm for farm yield gap analysis. FB denotes family-based and SS semi-specialized. I, M and E denote intensive, medium-intensive and extensive farm systems.

\begin{tabular}{|c|c|c|c|c|c|c|c|c|c|}
\hline System & $\begin{array}{l}\text { Total } \\
\text { land }^{1}\end{array}$ & $\begin{array}{c}\text { Owned } \\
\text { land } \\
\text { (ha) }\end{array}$ & $\begin{array}{c}\text { Rented } \\
\text { land }\end{array}$ & \multirow[t]{2}{*}{$\begin{array}{c}\text { Livestock }^{2} \\
(\mathrm{LU}) \\
\end{array}$} & \multirow[t]{2}{*}{$\begin{array}{c}\text { Livestock } \\
\text { density } \\
\left(\mathrm{LU} \mathrm{ha}^{-1}\right) \\
\end{array}$} & \multirow[t]{2}{*}{$\begin{array}{r}\text { Cows }^{3} \\
(\mathrm{Nr}) \\
\end{array}$} & \multirow[t]{2}{*}{$\begin{array}{c}\text { Milk } \\
\text { production } \\
\left(\mathrm{kg} \mathrm{cow}^{-1} \mathrm{~d}^{-1}\right) \\
\end{array}$} & \multirow[t]{2}{*}{$\begin{array}{l}\text { Hired } \\
\text { labor } \\
\text { (Labor }\end{array}$} & \multirow[t]{2}{*}{$\begin{array}{l}\begin{array}{l}\text { Family } \\
\text { labor }\end{array} \\
\text {-day } \mathrm{y}^{-1} \text { ) } \\
\end{array}$} \\
\hline & & & & & & & & & \\
\hline FBE & 57.9 & 0.0 & 57.9 & 18.9 & 0.33 & 12 & 7 & 0 & 548 \\
\hline FBM & 46.7 & 11.2 & 35.5 & 35.2 & 0.75 & 24 & 10 & 185 & 365 \\
\hline FBI & 23.6 & 23.6 & 0.0 & 31.2 & 1.31 & 18 & 14 & 387 & 148 \\
\hline SSE & 95.1 & 95.1 & 0.0 & 59.2 & 0.62 & 42 & 10 & 1110 & 114 \\
\hline SSM & 132.8 & 101.0 & 31.8 & 141.7 & 1.06 & 92 & 9 & 1208 & 365 \\
\hline SSI & 23.6 & 12.3 & 11.3 & 37.3 & 1.57 & 27 & 14 & 1000 & 532 \\
\hline Reference & 29.8 & --- & --- & 29.8 & 1.00 & 25 & 14 & --- & --- \\
\hline
\end{tabular}

\footnotetext{
${ }^{1}$ Owned and rented land used for grazing and cropping.

${ }^{2}$ Livestock units (LU) are defined in Mexican terms as a $450 \mathrm{~kg}$ LW lactating cow with a calf younger than 7 months.

${ }^{3}$ Total number of lactating cows in herd.
} 
the animal subsystem level, data were obtained pertaining to herd structure, milk production and composition, animal body weight and condition score, quality and intake of feedstuffs, and sanitary and reproductive management.

To determine soil physical and chemical properties and soil losses in grazing and cropping lands, soil sampling and runoff measurements were carried out during the rainy season on two selected farms. Following the Benchmark sampling design (Pennock et al., 2006), two $30 \times 30 \mathrm{~m}^{2}$ plots in grazing land and two in cropping land were sampled monthly. One soil sample was constituted by 30 subsamples randomly taken in each plot with the soil sampler buried up to $25 \mathrm{~cm}$ deep. Beside every plot, three runoff plots of $1 \times 5 \mathrm{~m}^{2}$ were installed to capture runoff after each precipitation event (Hudson, 1993).

A direct method of forage maize sampling was implemented to estimate forage maize yield (CrespoLira et al., 2007) previously harvested for silage or "stover" (local name for ground dry whole maize plants including cobs). In every parcel of forage maize on each farm, the number of maize plants in 2 $\mathrm{m}$ row length was counted and cut at $18 \mathrm{~cm}$ above ground level in 20 random samples. To measure the DM content and the nutritional value three samples were taken from each of the different forage types, i.e. fresh forage (after weighing and chopping) and silage and stover (at the end of the conservation process).

Because availability and management of feed differed importantly between dry and rainy seasons, dry matter intake (DMI) was analyzed for each season separately. For the dry season, DMI was calculated from the amount of purchased feedstuffs and conserved forage provided, such as concentrates, maize silage, stover and occasionally sugar cane tips, as reported by the farmer. For verification, DMI was measured directly once a month. During the rainy season, total DMI and forage intake and production from grazing lands were estimated based on the ME requirement of lactating cows (Baker, 2004). DMI from concentrates and conserved forage were estimated in the same way as in the dry season. Since no feed losses in the feed troughs were found, feed utilization was considered to be $100 \%$. Intake from grazing was estimated by deducting the ME taken in through concentrates and conserved forage from the total ME required for cattle, and computing forage production assuming $62 \%$ of forage utilization (Smart et al., 2010). This approach was used because of the difficulty of accurately measuring DMI of cattle when intake is composed of diverse grassland species and browsed shrubs and trees in a continuous stocking system. To estimate the nutrient composition of grazed forage, a monthly hand-plucked sample was analyzed. The parameters to estimate the requirements of DMI, ME and CP per age category of cattle were based on NRC (1989, 2001). For lactating cows, the ME requirements the original equation was based on an adjusted for equation lactating cows in for grazing systems in Mexico (Améndola, 2008):

$\mathrm{ME}=(\mathrm{MW} \times \mathrm{BM}) \times \mathrm{GCF}+\left(\mathrm{LW} \times 0.1 \times \frac{\mathrm{CWCh}}{\mathrm{DWG}}\right)+(\mathrm{MF} \times \mathrm{FC}+\mathrm{I}) \times \mathrm{MY}$ 
where ME is metabolic energy (Mcal d ${ }^{-1}$ ), MW metabolic weight $\left(\mathrm{LW}^{0.75}\right)$, BM basal metabolic factor (0.127), GCF grazing cost factor estimated as 1.31 for the dry season and 1.34 for the rainy season to account for the differences in length of the two seasons, LW live weight (kg), CWCh cost weight change factor (1.45), DWG daily weight gain ( $\left.\mathrm{g} \mathrm{d}^{-1}\right)$, MF milk fat (\%), FC milk fat cost factor (0.165), I intercept of the equation for calculating ME requirement per liter (0.577) and MY milk yield ( $\left.\mathrm{L} \mathrm{d}^{-1}\right)$. Monthly, quantitative farm information was collected on: milk used on the farm and sold, milk production per cow, number of dry and lactating cows, number of births, number of cows in heat, and purchase of inputs. Individual food ration was measured, body condition of the cows was visual estimated and mastitis incidence was established by the California mastitis test. Ten feces and urine samples were collected for chemical analysis.

$\mathrm{N}, \mathrm{P}, \mathrm{K}$ and total ash content were established by chemical analysis of samples of grazed and conserved forage, concentrates, milk, feces, urine, runoff, and soil. In the soil samples taken at beginning and at the end of the rainy season also bulk density and organic carbon were measured. ME content of feedstuffs was estimated through acid detergent fiber content (ADF) using the equation ME $=3.412-0.0322 \mathrm{x}$ ADF (Table 15.5 in NRC, 2001). The CP content in all feedstuffs was estimated using the macro-Kjeldahl method (Harris, 1970).

\subsubsection{Farming system analysis}

The FarmDESIGN model (Groot et al., 2012) was used to quantitatively evaluate the performance of the selected dairy farms. The model describes a farming system in terms of annual balances of $\mathrm{N}, \mathrm{P}, \mathrm{K}$, organic matter, labor and money. Separate balances of animal DMI, ME and CP were calculated for the dry and the rainy seasons to account for the major differences in feeding strategies. During the dry season, from December to June, the animals grazed but the amount of herbage ingested was small and almost all the DMI came from concentrates and conserved forage (Crespo, 2009). During the rainy season animals were grazed. The model was parameterized using the information collected at the individual farms. Model outputs provide insight into the current situation of each dairy farm, and help to identify key problems and production constraints.

\subsection{5. $N, P$ and $K$ balances}

Nutrient balances were developed for the farm as a whole and for the soil component (Fumagalli et al., 2011). At the farm level, N, P and K balances were calculated as the difference between nutrient inputs and outputs at the farm gate. Inputs included purchased fertilizers and animal feed, biological and non-symbiotic fixation, and atmospheric deposition whereas sold maize forage, animals, and milk were considered as outputs. To estimate the $\mathrm{N}, \mathrm{P}$ and $\mathrm{K}$ flows associated with animal production, total 
DMI of each feedstuff, sold milk and animals, and maize forage were multiplied by their corresponding $\mathrm{N}, \mathrm{P}$ and $\mathrm{K}$ contents.

The nutrient balances for the soil component were based on the differences between soil additions and removal of $\mathrm{N}, \mathrm{P}$ and $\mathrm{K}$. Additions included incorporation of forage residues, biological and nonsymbiotic fixation, atmospheric deposition, fertilizer application; removal comprised crop nutrient uptake, volatilization and erosion (Whitehead and Raistrick, 1990; Patra et al., 1996; Kirchmann and Lundvall, 1998). The soil N, P and K balances were calculated for cropland and grazing land separately to obtain an area-weighted average for calculating values at the farm level. Based on results of Cleveland et al. (1999) and Galloway et al. (2008) values for N-fixation, non-symbiotic N-fixation, and $\mathrm{N}$-deposition were taken to be $3.5,3.0$ and $7.0 \mathrm{~kg} \mathrm{~N} \mathrm{ha}^{-1} \mathrm{y}^{-1}$, respectively. Values for $\mathrm{P}$ and $\mathrm{K}$ deposition at regional level were assumed to be $1 \mathrm{~kg} \mathrm{P} \mathrm{ha}^{-1} \mathrm{y}^{-1}$ and $2 \mathrm{~kg} \mathrm{~K} \mathrm{ha}^{-1} \mathrm{y}^{-1}$ (Smaling and Fresco, 1993).

Nutrient surpluses were converted into monetary value by calculating the farm-specific cost per unit $\mathrm{N}, \mathrm{P}$ and $\mathrm{K}$ based on amounts and prices of the inorganic fertilizers used on each farm and their nutrient contents. The monetary value of the surpluses was found by multiplying the nutrient-specific value by the surplus of corresponding nutrient and summing values for $\mathrm{N}, \mathrm{P}$ and $\mathrm{K}$.

\subsubsection{Farm yield gap analysis}

Farms may differ in their management of crops, animals, manure and soils. These subsystems and their interactions determine production and environmental performance. To reduce costs and environmental impact and to increase self-reliance, farms could improve utilization of their own feed resources, feed the herd in a balanced manner to maximize feed use efficiency, and use the produced manure to support soil fertility. In addition, herd structure could be balanced in terms of the ratio between productive and non-productive individuals. Yield gaps, i.e. differences between current and attainable production levels, may occur for both crop and animal subsystems. Since these yield gaps at subsystem level affect each other, they have to be considered at the appropriate level of integration, i.e. the whole farm.

We expressed the farm yield gap as the difference between milk production on a real farm and the milk production attainable on a virtual 'reference' farm with the same area and with the same number of lactating cows as the real-world 'counterpart'. The virtual reference farm was constructed by combining best performing crop and animal production activities as observed among the 6 case study farms. We assumed that rangeland and improved pastures were used as grazing resources, and that maize was fed as silage instead of stover (Table 3.2). Production data for maize and improved pasture came from farm FBI, for rangeland data from farm SSM were used. The maize crop of farm FBI was fertilized at a rate of $180 \mathrm{~kg} \mathrm{~N} / \mathrm{ha}$. While the number of cows on each reference farm was based on those observed on the real 'counterpart', milk yield per cow was derived from measurements on the 
best performing farm (SSI) (Table 3.1): $14 \mathrm{~kg} \mathrm{cow}^{-1} \mathrm{~d}^{-1}$ with a protein and fat content of 3.3\% and $3.4 \%$, respectively. We assumed improved herd management with an annual cow replacement rate of $25 \%$, and equal distribution of young animals between calves and yearlings. Milk production was assumed to start at the age of 2 years, in agreement with the 'best practices' assumption for the reference farm. Feed rations were calculated by maximizing milk production per hectare of on-farm feed, conditional on maximum feed intake and less than $5 \%$ deviation from equilibrium feeding for ME and CP, using the optimization routines in the FarmDESIGN model (Groot et al., 2012). From the set of possible combinations of rangeland, improved pasture and maize silage that resulted in feasible rations, we selected one in which maize occupied $25 \%$ of the total feed area, similar to the largest proportion found in the set of case study farms (23.3\% on farm SSI). The remainder of the area of the reference farm was occupied by improved pasture (31\%) and rangeland (44\%) (Table 3.2). The onfarm produced feeds were able to support a milk production level of $2.7 \mathrm{Mg} \mathrm{ha}^{-1}$, which was limited by protein supply rather than metabolizable energy availability. Lifting the protein shortage by assuming import of CP with supplementary feed resulted in a productivity of $4.3 \mathrm{Mg} \mathrm{ha}^{-1}$. This attainable production level was used for whole-farm comparison of nutrient balances between the reference farms and the real farms.

Partial farm yield gaps were calculated to attribute the milk yield gap to the 3 major differences between a reference farm and its real-world counterpart: differences in herd management and livestock density, differences in proportions of cultivated crop areas and differences in crop productivity. The contribution of each component was calculated by sequentially changing the values used for the virtual farm to those of the real farm.

\subsection{Results}

\subsubsection{Farm yield gaps for on-farm feed production}

The milk production intensity increased strongly with increasing livestock density (Figure 3.1a). However, when considering the milk production that could be attributed to on-farm produced feed resources, milk production per unit of area increased more slowly, indicating that a large part of the increase in milk yield was related to enhanced inputs of external feed resources and the self-reliance for feeds declined with higher livestock density.

The farm yield gap analysis demonstrated that at a livestock density of $1.0 \mathrm{LU}^{-1} \mathrm{ha}^{-1}$ a milk production level of $2.7 \mathrm{Mg} \mathrm{ha}^{-1}$ would be attainable based on on-farm produced feeds, whereas with supplementary feed imports the production level of $4.2 \mathrm{Mg} \mathrm{ha}^{-1}$ could be attained. The farm yield gap for milk production solely based on on-farm feed resources between the reference farms and the case study farms ranged from $41 \%$ to $92 \%$ (Figure 3.1b). This yield gap declined with higher livestock density and was on average higher for family-based farms (78\%) than for semi-specialized farms 
(58\%). Although the overall average reduction could be attributed almost equally to shortcomings in herd management (18\%), allocation of crop proportions (23\%) and lower crop productivity (26\%), the causes of the yield gap differed strongly among farms (Figure 3.1b). These will be analyzed in more detail below.
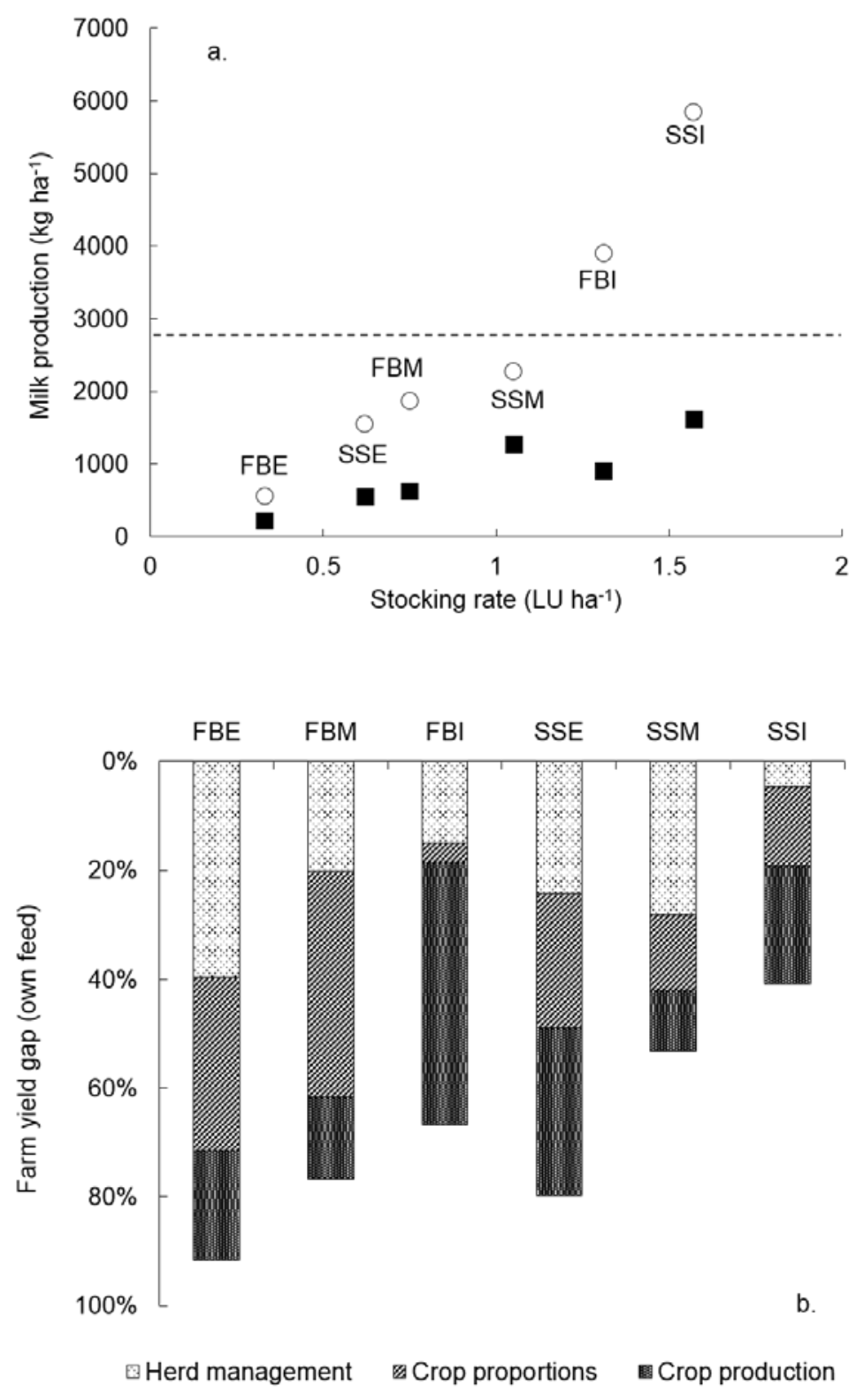

Figure 3.1. (a.) Milk production intensity in relation to the livestock density on different farms from own feed resources (squared solid symbol) and from total rations including imported feeds ( $\mathrm{O})$. The dashed line indicates the reference farm production level from own feeds at an optimal livestock density of $1.0 \mathrm{LU} / \mathrm{ha}$. (b.) Farm yield gap of case study farms compared to reference farms, and proportions of the gap that can be attributed to deficiencies in herd management, crop proportions and crop productivity. 


\subsubsection{Herd management}

The dominant breed on all farms was Holstein Frisian, but crosses of this breed with Zebu, Brown Swiss, and Jersey were also present. Average milk production was $4310 \pm 103 \mathrm{~kg} \mathrm{cow}^{-1}$ lactaction $^{-1}$ and the milk production rate was slightly higher and less variable in the dry season (from October to May) than in the rainy season (Figure 3.2).

Clear indications of herd management problems were observed (Table 3.2). The herd structure was imbalanced as the percentage of dry cows was higher than 16\% (assuming a lactation period of 305 days and a minimum calving interval of 365 days) and the number of heifers kept for replacement was high. The large numbers of dry cows and heifers (Table 3.2) is an indication of inadequate fertility management caused by for instance lack of identification of cows in heat, poor implementation of artificial insemination, low quality of semen or deficient postpartum animal health care, whereas the body condition score was within the acceptable range (between 2.8 and 3.5; Table 3.4). The prevalence of mastitis varied from 34 to $77 \%$ of lactating cows at any one time. The high proportion of unproductive animals and the occurrence of mastitis reduced the overall productivity of the herd and resulted in high feed costs for maintenance of non-productive animals. For farm SSI there was no yield gap relative to the reference production level that could be attributed to herd management, because the herd characteristics of this farm were adopted for the reference farm. The high number of heifers of farm SSI was compensated by a smaller number of calves than the reference farm and the
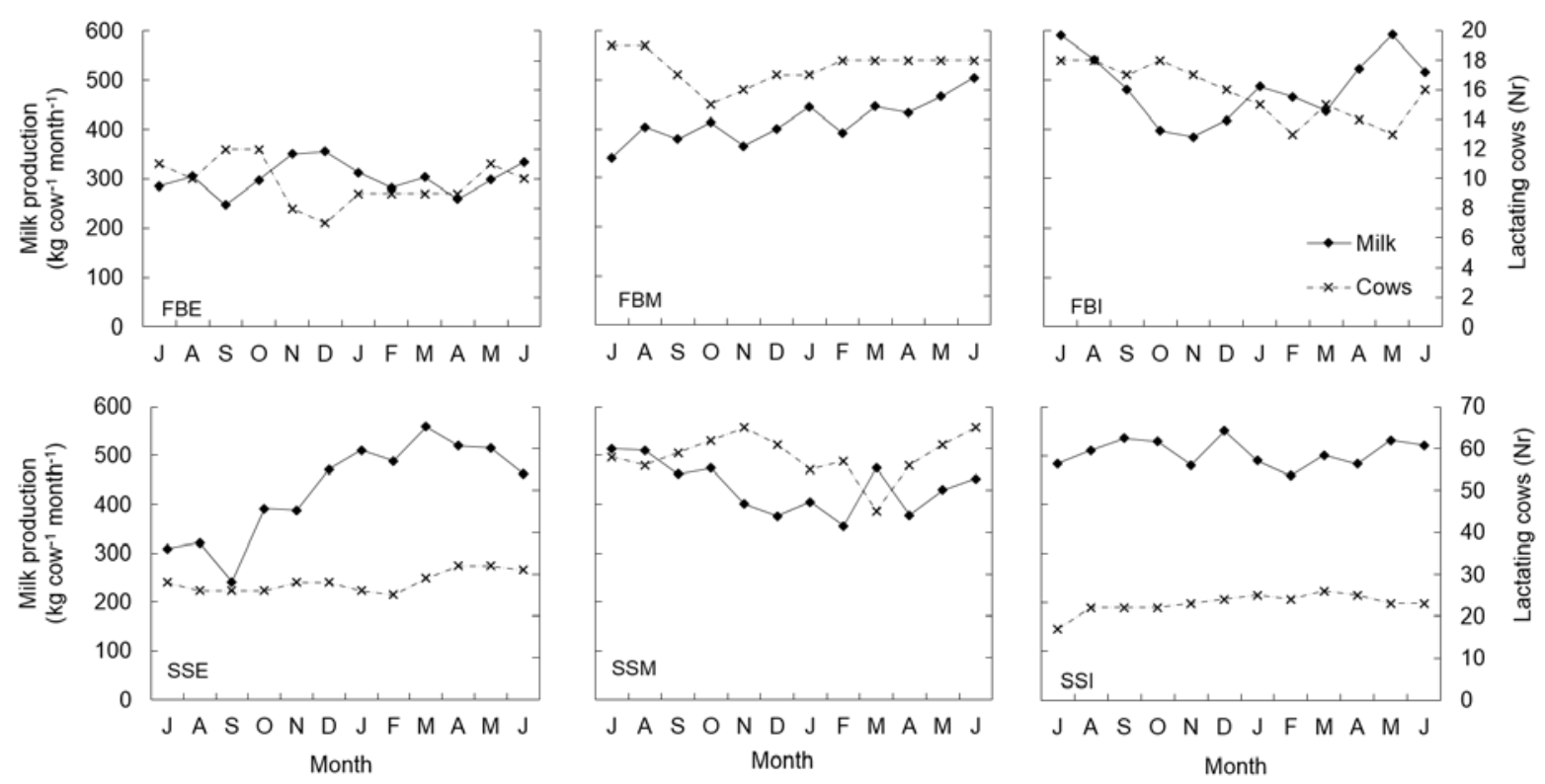

Figure 3.2. Monthly milk production per lactating cow (broken line) and number of lactating cows (solid line) in 2009/2010 on six farms representing extensive (E), medium-intensive (M) and intensive (I) family-based (FB) and semi-specialized (SS) dairy systems in Marcos Castellanos, Michoacán, Mexico. 
Table 3.2. Reproduction and lactation characteristics, herd structure and herd health status on six farms representing extensive (E), medium-intensive (M) and intensive (I) family-based (FB) and semi-specialized (SS) dairy systems in Marcos Castellanos, Michoacán, Mexico, and of the reference farm for farm yield gap analysis.

\begin{tabular}{|c|c|c|c|c|c|c|c|}
\hline \multirow{2}{*}{ System } & \multirow{2}{*}{$\begin{array}{c}\text { Calving } \\
\text { interval } \\
\text { (days) }\end{array}$} & \multirow{2}{*}{$\begin{array}{c}\text { Lactation } \\
\text { duration } \\
\text { (days) }\end{array}$} & \multicolumn{3}{|c|}{ Herd structure $(\%)^{1}$} & \multirow{2}{*}{$\begin{array}{l}\mathrm{AI}^{2} \\
(\%)\end{array}$} & \multirow{2}{*}{$\begin{array}{c}\text { Mastitis }^{3} \\
\text { (\%) }\end{array}$} \\
\hline & & & Dry cows & Calves & Heifers & & \\
\hline FBE & 438 & 353 & 19 & 33 & 67 & 0 & 34 \\
\hline FBM & 474 & 352 & 26 & 29 & 58 & 37 & 54 \\
\hline FBI & 356 & 320 & 10 & 39 & 83 & 27 & 77 \\
\hline SSE & 499 & 337 & 32 & 26 & 52 & 99 & 60 \\
\hline SSM & 438 & 277 & 37 & 30 & 61 & 40 & 75 \\
\hline SSI & 438 & 365 & 17 & 22 & 48 & 95 & 59 \\
\hline Reference & 365 & 305 & 16 & 35 & 35 & - & - \\
\hline
\end{tabular}

${ }^{1}$ Number of dry cows, calves and heifers expressed as a percentage of the total number of milk cows (lactating and dry).

${ }^{2}$ Cows artificially inseminated as a percentage of all cows served throughout the year.

${ }^{3}$ Cows with mastitis as a percentage of cows sampled in the dry and rainy seasons.

proportion of dry cows (and thus lactation length and calving interval) was the same as for the reference farm. The yield gap related to herd management (Figure 3.1b) was largest for farms FBE (38\%), SSE (22\%) and SSM (26\%).

This was related to low livestock density (for FBE and SSE) and low milk production per animal (for FBE and SSM), whereas for all these farms the percentages of dry cows and replacement heifers were high (Table 3.1).

\subsubsection{Crop management and animal feeding}

On all farms predominant land-use was grassland, either semi-natural rangeland or improved pastures (Table 3.3). Only the most intensive farms (FBI and SSI) utilized improved pastures with Rhodes grass (Chloris gayana) and annual ryegrass (Lolium multiflorum), respectively. Forage maize covered between 5 and 23\% of the farm area and was used for the production of stover and silage. In terms of forage production, the productivity of rangeland tended to be rather low (0.6 to $1.6 \mathrm{Mg} \mathrm{DM} \mathrm{ha}^{-1}$ year $^{-1}$ ) and although values for improved pastures were higher (2.8 to $3.4 \mathrm{Mg} \mathrm{DM} \mathrm{ha}^{-1}$ year $^{-1}$ ), the quality in terms of CP content was lower than for rangelands (Table 3.3). Maize yields ranged from 7.4 to 16.4 Mg DM ha ${ }^{-1}$ among farms (Table 3.3). Low maize yields were associated with low plant density due to low seeding rates and/or poor initial crop establishment. After maize harvest stover production resulted in larger losses of $\mathrm{CP}$ and ME than ensiling.

The yield gap related to crop management (proportions and yields) ranged from 27 to $60 \%$ when compared to the reference production level (Figure 3.1b). For the most intensive farms (FBI and SSI) 
this gap was caused mainly by low crop productivity, for farm FBI the productivity of rangeland was low and a large fraction of the maize was exported, and for farm SSI maize yields were low and maize

Table 3.3. Crop and grassland area, productivity and quality for six farms representing extensive (E), mediumintensive (M) and intensive (I) family-based (FB) and semi-specialized (SS) dairy systems in Marcos Castellanos, Michoacán, Mexico, and the reference farm for farm yield gap analysis. Shaded areas indicate crops selected for reference farm construction.

\begin{tabular}{|c|c|c|c|c|c|c|c|c|c|c|}
\hline \multirow{2}{*}{$\begin{array}{l}\text { Variable } \\
\text { Grazing land }^{1} \\
\end{array}$} & \multirow[t]{2}{*}{$\mathrm{E}$} & \multirow[t]{2}{*}{ FBM } & \multicolumn{2}{|c|}{ FBI } & \multicolumn{2}{|c|}{ SSE } & \multirow[t]{2}{*}{ SSM } & \multirow[t]{2}{*}{ SSI } & \multicolumn{2}{|c|}{ Reference } \\
\hline & & & & & & & & & & \\
\hline Type $^{2}$ & $\mathrm{R}$ & $\mathrm{R}$ & $\mathrm{R}$ & IP & $\mathrm{R}$ & $\mathrm{R}$ & $\mathrm{R}$ & IP & $\mathrm{R}$ & IP \\
\hline Area (ha) & 54.6 & 44.5 & 12.8 & 5.3 & 76.0 & 7.5 & 109.6 & 19.1 & 13.2 & 9.5 \\
\hline Yield (Mg DM ha ${ }^{-1}$ ) & 0.78 & 1.01 & 0.63 & 2.77 & 1.32 & 1.06 & 1.60 & 3.41 & 1.6 & 2.77 \\
\hline ME (Mcal kg-1) & 2.1 & 2.3 & 2.3 & 2.2 & 2.3 & 2.3 & 2.3 & 2.3 & 2.3 & 2.2 \\
\hline $\mathrm{CP}\left(\mathrm{g} \mathrm{kg}^{-1}\right)$ & 114 & 117 & 117 & 90 & 114 & 107 & 147 & 114 & 147 & 90 \\
\hline \multicolumn{11}{|l|}{ Forage maize } \\
\hline Area $(\mathrm{ha})^{3}$ & 2.6 & 2.2 & 5.5 & & 11.6 & & 23.2 & 4.5 & 7.5 & \\
\hline Yield (Mg DM ha-1) & 10.3 & 16.0 & 16.4 & & 7.7 & & 16.3 & 7.4 & 16.4 & \\
\hline Plant density $\left(\mathrm{m}^{-2}\right)$ & 4.3 & 5.3 & 7.1 & & 4.3 & & 5.6 & 5.0 & 7.1 & \\
\hline $\begin{array}{l}\text { Maize on-field cost (U) } \\
\left.\mathrm{ha}^{-1}\right)^{4}\end{array}$ & $\$ 331$ & 527 & 680 & & 868 & & 646 & 566 & 680 & \\
\hline $\begin{array}{l}\text { Maize on-field plus sile } \\
\text { cost }\left(\mathrm{US} \$ \mathrm{ha}^{-1}\right)\end{array}$ & & 807 & 105 & & 139 & & 968 & & 105 & \\
\hline $\begin{array}{l}\text { Maize on-field plus } \\
\text { stover production cost } \\
\left(\mathrm{US} \$ \mathrm{ha}^{-1}\right)\end{array}$ & 478 & & & & & & 200 & 916 & & \\
\hline $\mathrm{ME}_{\text {harvest }}\left(\mathrm{Mcal} \mathrm{kg}^{-1}\right)^{5}$ & 2.2 & 2.0 & 2.1 & & 2.3 & & 2.4 & 2.2 & 2.1 & \\
\hline $\mathrm{ME}_{\text {silage }}{ }^{5}$ & & 2.7 & 2.5 & & 2.6 & & 2.3 & & 2.5 & \\
\hline $\mathrm{ME}_{\text {stover }}{ }^{5}$ & 1.6 & & & & & & 2.1 & 2.6 & & \\
\hline $\mathrm{CP}_{\text {harvest }}\left(\mathrm{g} \mathrm{kg}^{-1}\right)^{5}$ & 79 & 116 & 107 & & 78 & & 88 & 95 & 107 & \\
\hline $\mathrm{CP}_{\text {silage }}{ }^{5}$ & & 80 & 96 & & 78 & & 81 & & 96 & \\
\hline $\mathrm{CP}_{\text {stover }}^{5}$ & 56 & & & & & & 76 & 66 & & \\
\hline
\end{tabular}

${ }^{1}$ DM: dry matter, ME: metabolic energy, CP: crude protein.

${ }^{2}$ Grazing land types: IP: improved pasture, R: rangeland.

${ }^{3}$ Net area cultivated.

${ }^{4}$ Cost of forage maize production until harvest.

${ }^{5}$ Metabolizable energy (ME) and crude protein (CP) of maize at harvest, or after ensiling and stover production, respectively. 
was conserved as stover, resulting in stronger quality reduction of the harvested material than for silage (Table 3.3). Farms FBI and SSI used $20-24 \%$ of the surface area for maize cultivation and a large proportion of their surface area as improved grasslands, so the impact of crop proportions was only marginal. For the other farms crop proportions contributed to the farm yield gap (15-44\% yield reduction relative to the reference production level; Figure 3.1b) due to low proportions of maize cultivation and smaller areas of improved pasture (Table 3.3). Moreover, the crop production levels of rangeland and maize on these farms were low, except for rangeland of farm SSM that was used to construct the reference farm, so that farm SSM exhibited a crop production related yield gap of only $11 \%$ due to lower maize yield than the reference farm.

\subsubsection{Rations and seasonal variation}

Roughage constituted the main component of the ration during both seasons, the proportion in the rainy season slightly exceeding that in the dry season (69\% vs. 55\%) (Table 3.4). During the rainy season, grazing was the main source of forage whereas in the dry season conserved forage produced on the farm and concentrates purchased locally were provided. The proportion of concentrates in the ration at herd level varied between $20 \%$ and $34 \%$ in the rainy season and between $30 \%$ and $73 \%$ in the dry season (Table 3.4). Dependence on purchased foodstuffs was similar in both seasons for the two farms with a livestock density of ca. $1 \mathrm{LU}^{-1}$ (i.e., FBI and SSM), whereas farms with lower (FBE, FBM and SSE) and higher (SSI) livestock density demonstrated less consistent ration composition and strongly enhanced feed imports in the dry season (Figure 3.3).

Differences between seasons in feed sources, composition of the rations and external dependence influenced feeding costs (Table 3.4). Feeding costs for the whole herd were 63\% higher during the dry season than during the rainy season and $41 \%$ for lactating cows. Deficiencies in crop and feed management and in herd management that were revealed in the farm yield gap analysis were reflected in ration use efficiency expressed in kg milk per unit of DMI (Figure 3.4a) and in feed costs per kg milk produced (Figure 3.4b).

\subsubsection{Nutrient balances}

The input of nutrients at the farm gate $\left(\mathrm{kg} \mathrm{ha}^{-1}\right)$ increased with milk production intensity $\left(\mathrm{kg}\right.$ milk ha $\left.{ }^{-1}\right)$. Major inputs of $\mathrm{N}$ and $\mathrm{K}$ came from bought feedstuff (Figure 3.5a and 3.5e), while inorganic fertilizer was the main source of P (Figure 3.5e). The $\mathrm{N}$ from feed inputs increased linearly with production intensity, whereas fertilizer inputs tended to level off (Figure 3.5a) because fertilizer inputs were relatively low for SSI compared to FBI. Milk was the main N output, but in some instances farms also exported substantial amounts of nutrients via crop products (Figure 3.5b). This was of particularly evident for FBI that exported $31 \mathrm{~kg} \mathrm{~N}$ ha $^{-1}$ as silage maize. On average, $\mathrm{N}, \mathrm{P}$ and $\mathrm{K}$ surpluses were $75 \pm 16,15 \pm 6$, and $19 \pm 6 \mathrm{~kg} \mathrm{ha}^{-1}$, respectively. The total $\mathrm{N}$ surplus increased with production intensity 


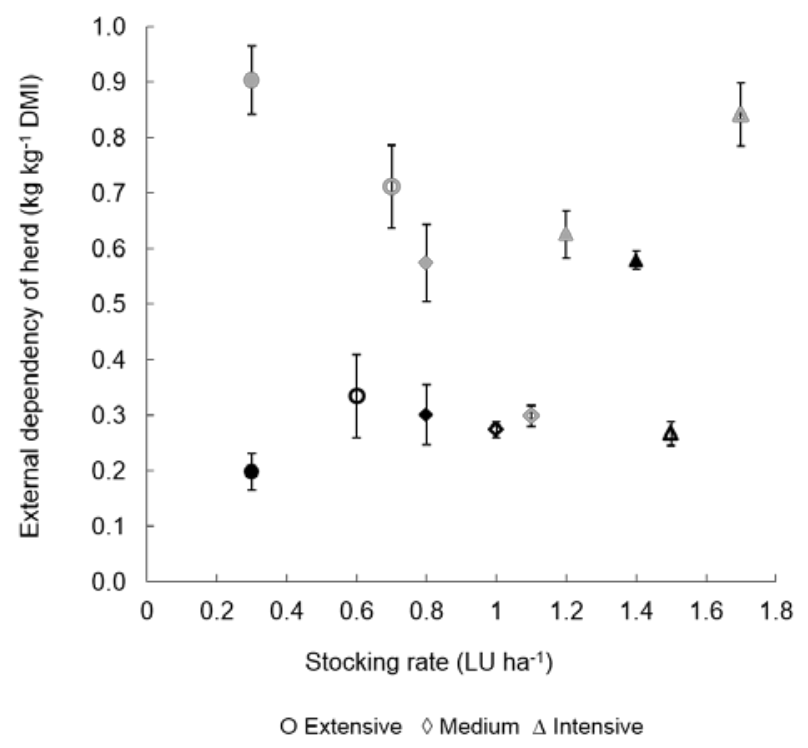

Figure 3.3. Relationship between livestock density and external feed dependency (calculated as the proportion of imported feeds in the animal ration) in 2009/2010 on six dairy farms representing extensive, medium-intensive, and intensive family-based (FB, open symbols) and semi-specialized (SS, solid symbols) dairy systems in Marcos Castellanos, Michoacán, Mexico. Black and grey symbols denote rainy and dry season, respectively.
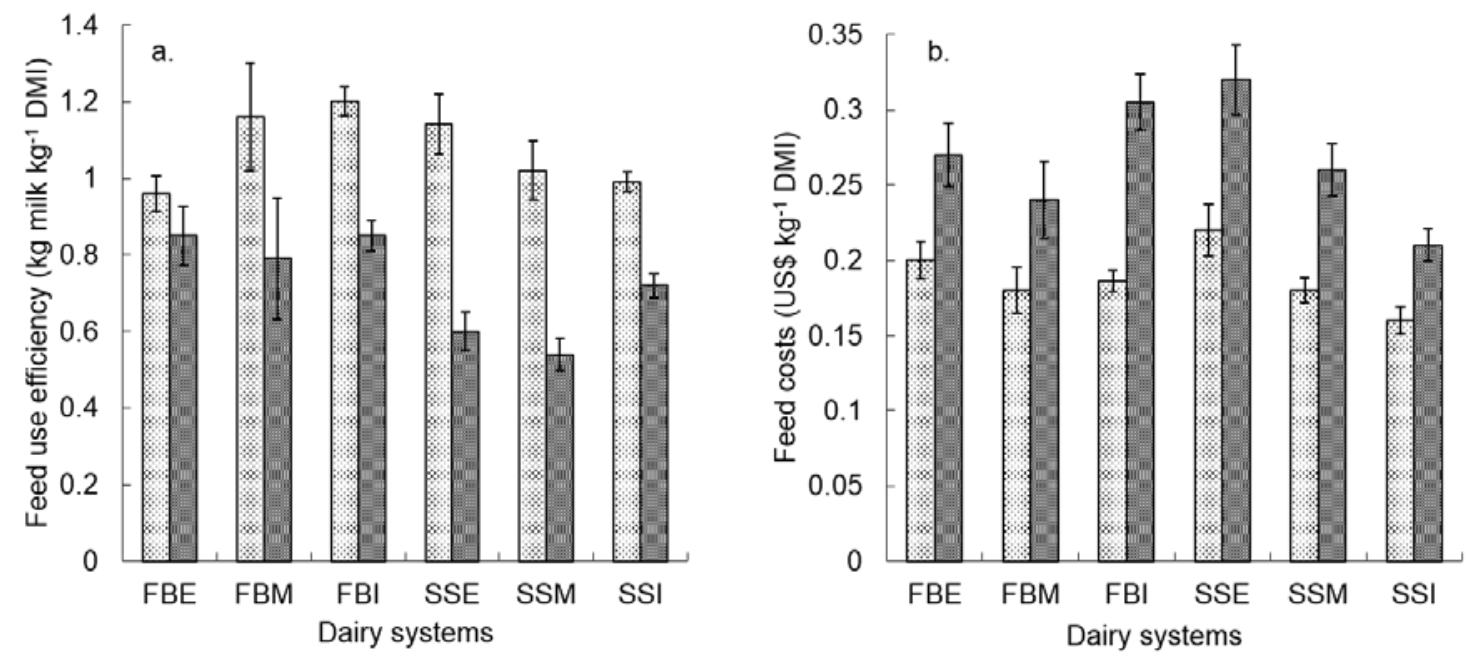

Figure 3.4. Feed use efficiency (a.) and feed costs (b.) for lactating cows (light grey) and at herd level (dark grey) on six dairy farms representing extensive (E), medium-intensive (M) and intensive (I) family-based (FB) and semi-specialized (SS) dairy systems in Marcos Castellanos, Michoacán, Mexico. 
Table 3.4. Animal intake, ration composition, ration nominal costs and animal body condition score per season of the herd on six dairy farms representing extensive (E), medium-intensive (M) and intensive (I) family-based (FB) and semi-specialized (SS) dairy systems in Marcos Castellanos, Michoacán, Mexico. Data were collected in $2009 / 2010$.

\begin{tabular}{|c|c|c|c|c|c|c|c|c|c|c|c|c|}
\hline \multirow{2}{*}{ Variable } & \multicolumn{6}{|c|}{ Rainy season $^{1}$} & \multicolumn{6}{|c|}{ Dry season $^{1}$} \\
\hline & FBE & FBM & FBI & SSE & SSM & SSI & FBE & FBM & FBI & SSE & SSM & SSI \\
\hline Intake (kg DM LU $\left.{ }^{-1} \mathrm{~d}^{-1}\right)^{2}$ & 10.6 & 8.4 & 9.7 & 13.0 & 11.1 & 13.6 & 8.4 & 8.8 & 9.6 & 10.1 & 10.5 & 14.5 \\
\hline Intake (kg DM $\left.100 \mathrm{~kg}^{-1} \mathrm{LW}\right)^{3}$ & 2.34 & 1.84 & 2.36 & 2.73 & 2.40 & 2.92 & 1.37 & 1.97 & 1.95 & 2.36 & 2.44 & 3.39 \\
\hline Forage ( $\left.\mathrm{g} \mathrm{kg}^{-1} \mathrm{DMI}\right)$ & 802 & 699 & 512 & 665 & 729 & 733 & 269 & 589 & 435 & 650 & 704 & 630 \\
\hline Concentrates (g kg $\left.{ }^{-1} \mathrm{DMI}\right)^{4}$ & 198 & 301 & 488 & 335 & 271 & 267 & 731 & 411 & 565 & 350 & 296 & 370 \\
\hline Feeding cost (US\$ $\left.\mathrm{kg}^{-1} \mathrm{DM}\right)$ & 0.08 & 0.14 & 0.22 & 0.11 & 0.13 & 0.15 & 0.29 & 0.23 & 0.27 & 0.27 & 0.14 & 0.15 \\
\hline Body condition score & 3.0 & 3.0 & 3.4 & 2.8 & 2.9 & 3.5 & 2.8 & 2.9 & 3.3 & 3.0 & 3.1 & 3.5 \\
\hline
\end{tabular}

\footnotetext{
${ }^{1}$ The "rainy" season pertains to the period from July to September when pastures provide a significant contribution to the ration; during the "dry" season, from December to June, there is very limited grazing.

${ }^{2}$ Livestock unit (LU) is defined in Mexican terms as a $450 \mathrm{~kg} \mathrm{LW}$ lactating cow with a calf younger than 7 months.

${ }^{3}$ The DMI expresses the intake as a percentage of the body weight (kg LW).

${ }^{4}$ Concentrate values represent their content (g) per kilogram of DMI.
}

(Figure 3.5c), although the N surplus per unit of milk decreased (Figure 3.5d). Surpluses of P and K tended to increase with production intensity, although the relation was less pronounced than for $\mathrm{N}$ (Figure 3.5e). The total $\mathrm{N}$ surplus was nearly identical to the amount of $\mathrm{N}$ excreted via urine and manure (Figure 3.5f), which showed that shortcomings in manure handling are a primary cause of nutrient losses.

Nutrient balances of the reference farms and their real-world counterparts were compared. The $\mathrm{N}$ inputs with supplementary feeds needed to reach the target yield of $4.3 \mathrm{Mg}$ milk ha- $^{-1}$ for the reference farm were substantially lower than the trend for the real farms (Figure 3.4a), but the $\mathrm{N}$ surpluses per ha and per unit of product were only slightly lower than the trend for the real farms (Figures 3.5c and 3.5d). This is attributable to the fertilizer input of $180 \mathrm{~kg} \mathrm{~N} \mathrm{ha}^{-1}$ for cultivation of the maize crop that was adopted on the reference farms.

\subsection{Discussion}

In this study we estimated the yield gap at farm level, by comparing actual farm performance to that of virtual reference farms for which we assumed best practices observed in the case study region to construct attainable yield levels based on-farm and imported feed resources. The farm yield gap 
analysis pointed to management constraints in the crop, animal and manure components of the farm systems. Although the values of the model parameters were collected directly on the case study farms, the analysis was based on a number of simplifying assumptions, which call for prudent interpretation of the results. The reference farms were based on maximizing feed self-reliance in terms of ME and $\mathrm{CP}$, but did not consider objectives concerning family income, operating profit, labor, nor the uncertainty in land tenure. A single yield level was assumed for maize, rangeland and improved pastures; variation between fields and farms was not taken into account. The options for on-farm feeding were based on what was practiced in the region. It will be highly desirable to investigate a broader range of options, including those with innovative feed sources such as grass-legume pastures or protein banks that can help to close the CP gap. And finally, farmer skills and abilities were not considered in the construction of the reference farm. Our observations, however, suggested that changes in the production systems should be accompanied by improvement of managerial abilities (cf. Groot et al., 2006). For some farmers projected increases in crop and milk yields were considerable (Figure 3.1; Table 3.2). Such improvements could only be attained by management changes throughout the farm based on a clear strategy, focusing on better reproductive, sanitary, and feed management, since the calving interval, age at first calving, prevalence of mastitis, and external dependence on feedstuffs have to be reduced to close the gap (cf. Table 3.2).

The three dimensions of farm management that determine the yield gap (herd management, crop proportions and crop productivity) were assumed to be additive. In reality there will be interactions, but because we focus primarily on effects of feeding strategy and on milk yield as dominant response variable this seems justified, since milk production responds quickly to feeding. An exceptional phase in this respect is early lactation, wherein feed deficiencies could be compensated by mobilization of body reserves resulting in decline in body condition score. However, the farmers fed cows in early lactation sufficiently so that body condition scores did not decline considerably. Moreover, we were particularly interested in the relative importance of the three determining management aspects, which is well reflected even when assuming additive effects.

Herd management and forage availability in the course of the year dictated to a large extent the overall productivity and profitability of the studied dairy systems. The observed shortcomings in health care and reproductive management of the herd were the most likely cause for the unbalanced herd structure and low milk production per cow. Insufficient forage production in grazing lands and cropland caused a strong dependency on external feed (Figure 3.3), which affected overall profitability negatively and translated into important nutrient surpluses, which potentially cause negative environmental impacts at both the local and regional level. The farm yield gap analysis showed that better crop and herd management could improve the self-reliance of farms considerably, although additional adjustments on the farms would be needed to improve whole-farm nutrient use efficiency and reduce nutrient losses. 

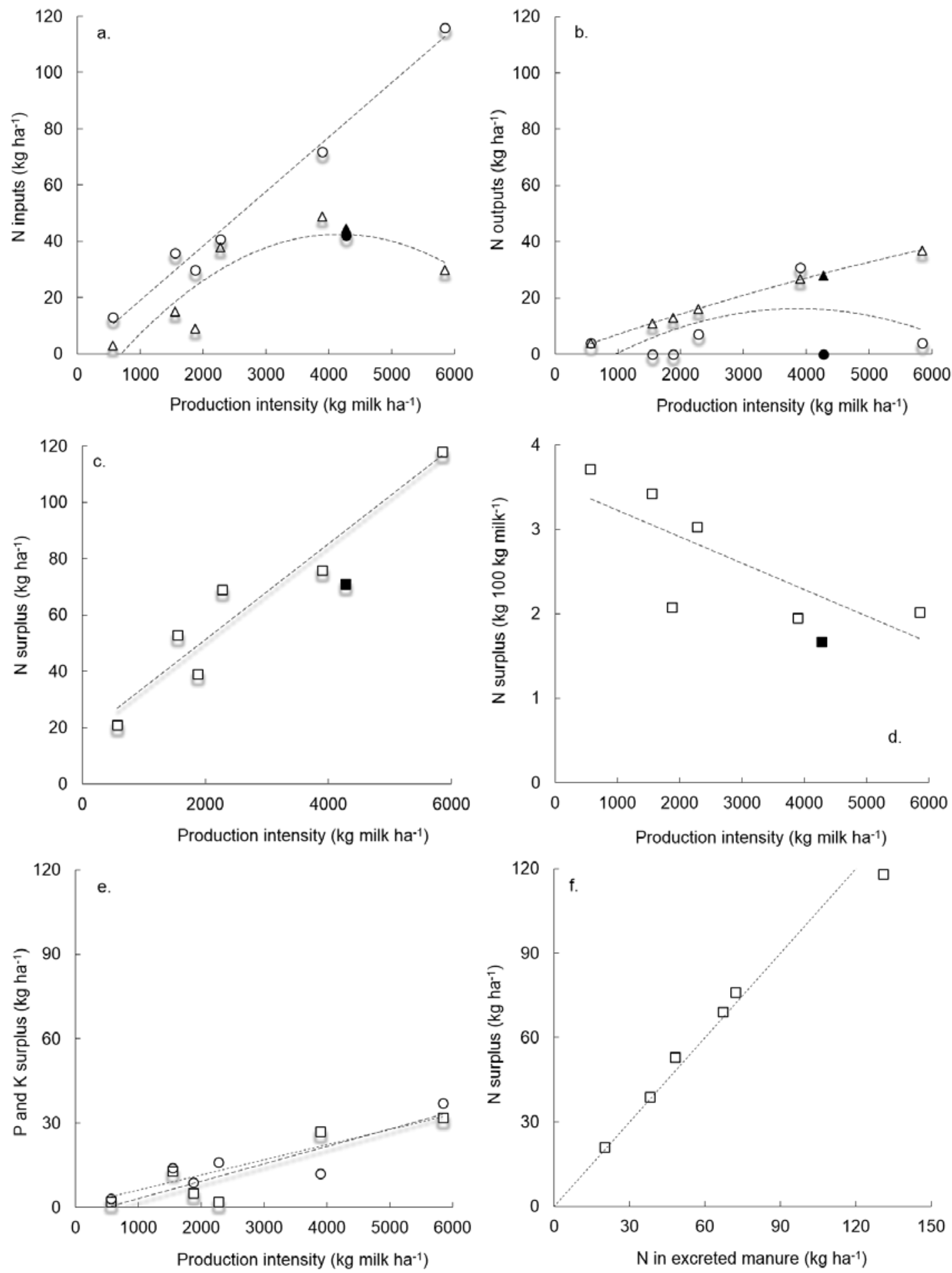

Figure 3.5. Nutrient use indicators of 6 case study dairy farms in North West Michoacán as a function of production intensity (a.-e.) and manure production (f.). (a) $\mathrm{N}$ inputs (fertilizer $\Delta$, feed $\circ$ ); (b) $\mathrm{N}$ outputs (milk and meat $\Delta$, and crop products $\circ$ ); (c) $\mathrm{N}$ surplus per unit of farm area; (d) $\mathrm{N}$ surplus per unit of product; (e) $\mathrm{P}$ and $\mathrm{K}$ surpluses per unit of farm area $(\mathrm{P} \square, \mathrm{K} \circ)$ as a function of production intensity (kg milk ha ${ }^{-1}$ ); (f) $\mathrm{N}$ surplus as a function of excreted manure. Solid symbols denote values used for the reference farm. Dashed lines indicate average trends. Inputs from symbiotic and nonsymbiotic $\mathrm{N}$ fixation and deposition are not shown, but were included in the surplus calculations. 
Milk yield revealed inefficiencies associated with herd structure and management (Table 3.1; Figure 3.4). When considering only lactating cows, milk production by both the family-based and the semispecialized dairy systems was similar to the regional averages of respectively 3800 and $4500 \mathrm{~kg} \mathrm{cow}^{-1}$ lactaction $^{-1}$ reported in the literature (Amendola, 2002; Espinoza-Ortega et al., 2005). The level and quality of animal nutrition is one of the most important production constraints in smallholder livestock systems (Thornton, 2010). In North-west Michoacán there are two contrasting feed management strategies associated with distinct seasonal rainfall patterns, namely open grazing during the rainy season and supplementary feeding during the dry season. During the rainy season, animals grazed mostly on rangelands, which consist of 107 different species of the native flora distributed at regional scale (Cortez-Arriola, 2015). Although SAGDER (2000) reported that in this region rangelands can typically hold stocking rates of $0.13 \mathrm{LU} \mathrm{ha}^{-1}$, we observed much higher livestock density in the case study farms (Table 3.1). Replacing rangelands with improved pastures can increase forage production by about $200 \%$ (Table 3.3), thereby reducing farm dependence on external feedstuff during the rainy season.

During the dry season, rangeland-based roughages were replaced by conserved maize forage (silage maize and stover), alfalfa hay, and ground sugar cane tips. None of the farms produced enough conserved forage to replace grazing, resulting in a larger share of bought products (Table 3.4; Figure 3.3). Nevertheless, feed balance calculations showed that shortage of CP in the dry season ration was likely on 4 out of 6 farms as well as on the reference farms. Potential on-farm alternatives to overcome this shortcoming include the establishment of improved grass-legume pastures or protein banks (Ibrahim and 't Mannetje, 1998; Arriaga et al., 2000). Calculations indicated shortage of ME on one farm at herd scale, which may be a further indication of the need to improve management skills.

The studied dairy systems were characterized by appreciable N, P, and K surpluses, which points to inefficiencies, high potential losses and/or environmental emissions (Koelsch, 2005; Powell et al., 2010). Sotelo et al. (2005), Ramírez et al. (2007) and Silva-García et al. (2006) reported that agricultural activities developed in the "Chapala" sub-basin cause negative environmental impacts for Lake Chapala and the surrounding areas. Large loading rates of $\mathrm{N}$, orthophosphates, and total $\mathrm{P}$ compounds originating from fertilizers and wastewater with manure from agricultural areas are mentioned as causes of eutrophication. This study shows that there is scope for improvement of both environmental and economic performance of farms by implementing tactical and strategic system changes (cf. Shah et al., 2013).

The high surpluses appear to result first of all from poor manure management. Most dairy farms in the study region have implemented no measures for collecting and re-cycling dairy manure within their production system. Manure is perceived as a waste product that costs money and labor to be removed, rather than a valuable resource that can help to sustain soil fertility. One of the key issues is that due to poor grazing management, manure tends to accumulate in small areas where it leads to high gaseous 
emissions, soil degradation, and nutrient loading of surface waters due to runoff (Van der Molen et al., 1998). Changes in grazing management could promote more even manure deposition, reduce emissions, and support more effective utilization by closing nutrient cycles. Cycling dairy cattle over different areas and land-use types can increase manure-based NUE by 30-50\% (Powell et al., 2006; Powell et al., 2010).

\subsection{Conclusions}

Through integrated assessment of representative farms with different intensification levels we revealed key differences in farm management practices that impact on the productivity and profitability of dairy systems in NW Michoacán. The results of our analysis, pointing to large dependence on external inputs, poor internal efficiencies and acute environmental externalities, suggest that current dairy farming in the region is unsustainable. Small dairy farms are caught in an intensification trap that results from the implementation of standard technological packages with poor adaptation to local conditions - notably to the long dry season. A number of strategies and management practices developed by some local producers were identified that may help other farmers avoid the intensification trap. These were evaluated in a farm yield gap analysis to account for interactions between field and animal level changes. Improved production and nutrient use efficiencies were shown to result from more attention for on-farm feed production for the rainy season and particularly for the dry season, more attention for balanced feed rations, and more attention for cattle management to reduce inter-calving periods and improve cow health. In addition to these changes, avoiding local excess of plant nutrients by better manure management may be expected to benefit both environmental and economic performances. Common denominator in the changes is reducing external nutrient inputs by increased farm-internal nutrient cycling.

\subsection{Acknowledgements}

This research was funded by the EULACIAS project (EU FP6- 5832004-INCO-dev-3; contract nr 032387). We thank the dairy farmers of Marcos Castellanos, specially to Arturo Padilla, Daniel Chávez, Everardo Haro, Filiberto García, Honorato González, and José Luis Orozco for their cooperation and willingness to be part of this project. We are grateful to our colleagues Ramés Salcedo Vaca, Máximino Huerta Bravo, Luis Humberto Valencia Chávez, Efrén Trujillo López, Isela J. López Herrera, and Heriberto Estrella Quintero for their important support during field work and in project management. 


\subsection{References}

Amendola, R. D., 2002. A dairy system based on forages and gazing in temperate Mexico. PhD thesis Wageningen University, The Netherlands. 269 p.

Améndola, R., Castillo, E., and Martínez, P.A., 2005. Country pasture / Forage resources profiles: Mexico - part II. Food and Agriculture Organization of the United Nations. In: http://www.fao.org/ag/AGP/agpc/doc/Counprof/Mexico/Mexico2.htm.

Retrieved: December, 2009.

Améndola, R.D., 2008. Balance de la alimentación en la producción intensiva de leche en pastoreo. Posgrado de Producción Animal. Universidad Autónoma Chapingo. In: http://www.edicionespecuarias.com.mx/pdf/complemento_editorial/nutriciero/2008/30/pohC EBALANCE\%20ALIMENTACI\%D3N.pdf. Retrieved: February, 2011.

Arriaga J, C., Espinoza O., A., Albarrán P., B., and Castelán O., O., 2000. Producción de leche en pastoreo de praderas cultivadas: una alternativa para el Altiplano Central. Ciencia Ergo Sum 6 (3): $290-300$.

Baker, R.D., 2004. Estimating herbage intake from animal performance, in: Penning P. D. (Ed.), Herbage intake handbook. Second Edition. The British Grassland Society. University of Reading, Reading, RG6 6A. Pp. 95 - 120.

Bhatia, V.S., Singh, P., Wani, S.P., Kesava R., AVR, and Srinivas, K., 2006. Yield gap analysis of soybean, groundnut, pigeonpea and chickpea in India using simulation modeling. International Crops Research Institute for the Semi-Arid Tropics (ICRISAT). Global Theme on Agroecosystems Report no. 31. Andhra Pradesh, India. 156 p.

Cleveland, C.C., Towsend, A.R., Schimel, D.S., Fisher, H., Howarth, R.W., Hedin, L.O., Perakis, S.S., Latty, E.F., Von Fisher, J.C., Elseroad, A., and Wasson, M.F., 1999. Global pattern of terrestrial biological nitrogen $\left(\mathrm{N}_{2}\right)$ fixation in natural ecosystems. Global Biogeochemical Cycles 13 (2): $623-645$.

Cortez-Arriola, J., Rossing, W.A.H., Améndola M., R.D., Scholberg, J.M.S., Groot, J.C.J., and Tittonell, P., 2015. Leverages for on-farm innovation from farm typologies? An illustration for family-based dairy farms in north-west Michoacán, Mexico. Agricultural Systems 135: $66-76$.

Crespo-Lira, H., Améndola-Massiotti, R.D., and Brugueño-Ferreira, J.A., 2007. Green chop maize forage production in temperate Mexico. J. Anim. Sci. 85 Supl 1: 41.

Crespo L., H., 2009. Balance entre consumo y gasto de energía por actividad de vacas lecheras pastoreando pastizal nativo. Maestría en Ciencias en Innovación Ganadera. Universidad Autónoma Chapingo. Edo. de México, México. 61 p. 
Espinoza-Ortega, A., Álvarez-Macías, A., Del Valle, M. del C., and Chauvete, M., 2005. Small-holder (campesino) milk production systems in the highlands of Mexico. Técnica Pecuaria México 43 (1): $39-56$.

European Comission, 2011. EU dairy farms report 2011. Directorate-General for Agriculture and Rural Development. In: http://ec.europa.eu/agriculture/rica/pdf/Dairy_report2011.pdf. Retrieved: May, 2012.

Figueroa-Viramontes, U., Cueto-Wong, J.A., Delgado, J.A., Núñez-Hernández, G., Reta-Sánchez, D.G., Qiroga-Garza, H.M., Faz-Contreras, R., and Márquez-Rojas, J.L., 2010. Estiércol de bovino lechero sobre el rendimiento y recuperación aparente de nitrógeno en maíz forrajero. Terra Latinoamericana 28(4): 361 - 369.

FIRA, 1997. Oportunidades de desarrollo de la lechería en México. FIRA-Banco de México, Boletín informativo Vol. XXIX, Núm. 294. 36 p.

Fumagalli, M., Acutis, M., Mazzetto, F., Vidotto, F., Sali, G., and Bechini, L., 2011. An analysis of agricultural sustainability of cropping systems in arable and dairy farms in an intensively cultivated plain. Europ. J. Agronomy 34: 71 - 82.

Galloway, J.N., Townsend, A.R., Erisman, J.W., Bekunda, M., Cai, Z., Freney, J.R., Martinelli, L.A., Seitzinger, S.P., and Sutton, M.A., 2008. Transformation of the nitrogen cycle: recent trends, questions, and potential solutions. Science 320: 889 - 892.

Groot, J.C.J., Oomen, G.J.M., and Rossing, W.A.H., 2012. Multi-objective optimization and design of farming systems. Agricultural Systems 110: 63 - 77.

Groot, J.C.J., Rossing, W.A.H., and Lantinga, E.A., 2006. Evolution of farm management, nitrogen efficiency and economic performance on Dutch dairy farms reducing external inputs. Livestock Science 100: 99 - 110.

Harris, L.E., 1970. Nutrition research techniques for domestic and wild animals: Volume I. An international record system and procedures for analyzing samples. Lorin E. Harris, 1408 Highland Drive, Logan. Utah 84321, U.S.A. 240 p.

Herrero, M., Thornton, P.K., Notenbaert, A.M., Woods, S., Msangi, S., Freeman, H.A., Bossio, D., Dixon, J., Peters, M., Van de Steeg, J., Lynam, J., Parthasarathy R., P., Macmillan, S., Gerard, B., McDermott, J., Seré, C., and Rosegrant, M., 2010. Smart investments in sustainable food production: revisiting mixed crop-livestock systems. Science 327: 822 825.

Hudson, N.W., 1993. Field measurement of soil erosion and runoff. Food and Agriculture Organization of the United Nations (FAO). Rome, Italy. In: http://www.fao.org/docrep/T0848E/t0848e-07.htm\#P734_33062. Retrieved: March, 2009. 
Ibrahim, M.A., and 't Mannetje, L., 1998. Compatibility, persistence and productivity of grass-legume mixture in the humid tropics of Costa Rica. 1 Dry matter yield, nitrogen yield, and botanical composition. Tropical Grasslands 32: 96 - 104.

Kirchmann, H., and Lundvall, A., 1998. Treatment of solid animal manures: identification of low $\mathrm{NH}_{3}$ emission practices. Nutrient Cycling in Agroecosystems 51: 65-71.

Koelsch, R.K., 2005. Evaluating livestock system environmental performance with whole-farm nutrient balance. J. Environ. Qual. 34: 149 - 155.

Martínez M., D., Hernández G., A., Enríquez Q., J.F., Pérez P., J., González M., S.S., and Herrera H., J.G., 2008. Effect of defoliation management on herbage yield in Isleno grass (Brachiaria humidicola CIAT 6133). Téc Pecu Méx 46 (4): 427 - 438.

Nin-Pratt, A., Johnson, M., Magalhaes, E., You, L., Diao, X., and Chamberling, J., 2010. Yield gap in West and Central Africa. International Food Policy Research Institute. Washington, D.C., U.S.A. 140 p.

NRC, 1989. Nutrient requirements of dairy cattle: Sixth Revised Edition. National Academy Press, Washington, D. C.. 157 p.

NRC, 2001. Nutrient requirements of dairy cattle: Seventh Revised Edition. National Academy Press, Washington, D. C.. 381 p.

Patra, A.K., Burford, J.R., and Rego, T.J., 1996. Volatilization losses of surface - applied urea nitrogen from Vertisols in the Indian semi-arid tropics. Biol Fertil Soil 22: 345 - 349.

Pennock, D., Yates, T., and Braidek, J., 2006. Soil sampling designs. In: Soil sampling and methods of analysis. M. R. Carter and E. G. Gregorich (Ed). Second Edition. Canadian Society of Soil Science. Florida, USA.

Powell, J.M., Jackson-Smith, D.B., McCrory, D.F., Saam, H., and Mariola, M., 2006. Validation of feed and manure data collected on Wisconsin dairy farms. J. Dairy Sci. 89: 2268 - 2278.

Powell, J.M., Gourley, C.J.P., Rotz, C, A., and Weaver, D.M., 2010. Nitrogen use efficiency: A potential performance indicator and policy tool for dairy farms. Environmental Science \& Policy 13: $217-228$.

Ramírez S., H.U., Zárate del V., D.F., García G., M.E., de la Torre V., O., Israde A., I., and Meulenert P., Á.R., 2007. Disolución de sílice biogénica en sedimentos de lagos utilizados como bioindicadores de calidad del agua. e-Gnosis 5 (4): 1 - 19.

SAGARPA, 2000. Situación actual y perspectiva de la producción de leche de ganado bovino en México 1990-2000. Secretaría de Agricultura, Ganadería, Desarrollo Rural, Pesca y Alimentación. In: http://www.sagarpa.gob.mx/ganaderia/Publicaciones/Lists. Retrieved: May, 2011.

SAGARPA, 2011. Boletín de Leche Enero - Marzo. Secretaría de Agricultura, Ganadería, Desarrollo $\begin{array}{lllll}\text { Rural, } & \text { Pesca } & \text { y }\end{array}$ 
http://www.campomexicano.gob.mx/portal_siap/Integracion/EstadisticaDerivada/ComercioE xterior/Estudios/BoletinLeche/Leche-May11.pdf. Retrieved: August, 2011.

SAGDER, 2000. Coeficientes de agostadero de la República Mexicana Estado de Michoacán. Secretaría de Agricultura y Recursos Hidráulicos-Comisión Técnico Consultiva para la Determinación Regional de los Coeficientes de Agostadero. Michoacán, México. 91 p.

Shah, G.A., Groot, J.C.J., Shah, G.M., and Lantinga, E.A., 2013. Simulation of long-term carbon and nitrogen dynamics in grassland-based dairy farming systems to evaluate mitigation strategies for nutrient losses. PLoS ONE 8(6) art. no. e67279.

Smart, A.J., Derner, J.D., Hendrickson, J.R., Gillen, R.L., Dunn, B.H., Mousel, E.M., Johnson, P.S., Gates, R.N., Sedivec, K.K., Harmoney, K.R., Volesky, J.D., and Olson, K.C., 2010. Effects of grazing pressure on efficiency of grazing on North American Great Plains rangelands. Rangeland Ecology \& Management 63(4): 397 - 406.

Secretaría de Gobierno, 2010. H. Ayuntamiento Constitucional de Marcos Castellanos: Plan de Desarrollo Municipal. Periódico Oficial del Gobierno Constitucional del Estado de Michoacán de Ocampo. Morelia, Michoacán. Tomo CXLIX, Núm. 46: 16 p.

SEMARNAT, 2003. Informe de la situación del medio ambiente en México 2002. Compendio de Estadísticas Ambientales: 2. Vegetación y uso del suelo. Secretaría de Medio Ambiente y Recursos Naturales. D.F., Méx.. 31 - 83.

Silva G., J.T., Rodríguez C., R., Ochoa E., S., and López D., S., 2002. Lake Chapala and the Cienega aquifer: Chemical evidence of hydraulic communication. Geofisica International 41(1): 63 73.

Silva-García, J.T., Ochoa-Estrada, S., Cristóbal-Acevedo, D., and Estrada-Godoy, F., 2006. Calidad química del agua subterránea de la Ciénega de Chapala como factor de degradación del suelo. Terra Latinoamericana 24: 503 - 513.

Smaling, E.M.A., and Fresco, L.O., 1993. A decision-support model for monitoring nutrient balances under agricultural land use (NUTMON). Geoderma 60: 235 - 256.

Sosa R., E.E., Cabrera T., E., Pérez R., D., and Ortega R., L., 2008. Dry matter seasonal production in grasses and legumes in Quintana Roo, México. Téc Pecu Méx 46(4): 413 - 426.

Sotelo, E., Cardona, N., Fregoso, A., Enríquez, C., Garrido, A., Caire, G., and Cotler, H., 2005. Acciones estratégicas para la recuperación de la cuenca Lerma-Chapala: Recomendaciones técnicas para las diecinueve subcuencas. Instituto Nacional de Ecología. 113 p.

Thornton, P.K., 2010. Livestock production: recent trends, future prospect. Phil. Trans. R. Soc. B 365: $2853-2867$.

Van der Molen, D. T., Breeuwsman, A., and Boers, P.C.M., 1998. Agricultural nutrient losses to surface water in the Netherlands: Impact, strategies, and perspectives. J. Environ. Qual. 27: 4 -11 . 
Van Ittersum, M.K., Cassman, K.G., Grassini, J.W., Tittonell, P., and Hochman, Z., 2013. Yield gap analysis with local to global relevance - A review. Field Crops Research 143: 4 - 17.

Whitehead, D.C., and Raistrick, N., 1990. Ammonia volatilization from five nitrogen compounds used as fertilizers following surface application to soils. J. Soil Sci. 41: 387 - 394. 

Chapter 4: Alternative options for the sustainable intensification of smallholders dairy farms in Northwest Michoacán, Mexico

José Cortez-Arriola, Jeroen C.J. Groot, Walter A.H. Rossing, Johannes M.S. Scholberg, Ricardo D. Améndola Massiotti, Pablo Tittonell. 


\begin{abstract}
Although Mexico aims to be self-sufficient in milk, domestic prices for milk are low due to trade liberalization, which resulted in imports of large amounts of milk powder, mainly from the United States. This situation threatens the livelihoods of smallholder dairy farmers. With varying success, farmers have tried to increase revenues by intensifying production through increased purchase of concentrates and production per cow, but this also resulted in substantial environmental problems. In this paper we combine a whole-farm model with data from representative pilot farms to explore alternative intensification pathways that more adequately can support the multi-objective setting of smallholders. Pilot dairy farms were defined in two categories: family-based (FB) and semispecialized (SS), each at three levels of intensification: extensive (E, $<0.8 \mathrm{LU} \mathrm{ha}^{-1}$ ), medium-intensive $\left(\mathrm{M},>0.8\right.$ and $<1.2 \mathrm{LU} \mathrm{ha}^{-1}$ ), and intensive (I, >1.2 LU ha $\left.{ }^{-1}\right)$. We aimed to explore management alternatives that enhance farm economic performance, while improving resource use efficiency and reducing negative environmental impacts. For each of the six pilot farms a large set of Pareto-optimal farm configurations was generated using the whole farm model in combination with a genetic algorithm. Applying a multivariate analysis, the set of alternatives were classified in three groups that respectively aimed to: a) maximize profitability ('economic'), b) maximize organic matter (OM) balance ('environmental'), and c) minimize labor used, $\mathrm{N}$ balance and feeding costs ('integrated'). FBI, SSI and SSM farms had the widest ranges of opportunities for change, mainly to maximize profitability and/or OM balance, and to minimize $\mathrm{N}$ balance. Synergies were found between profitability and feed costs, and between feed costs and $\mathrm{N}$ balance; trade-offs occured between $\mathrm{OM}$ balance with feed costs and $\mathrm{N}$ balance. In terms of overall system performance, while environmental alternatives were dominanted in FBE, FBI, SSE, and SSI, the economic were less abundant in FBE, SSE, SSM and SSI. Within groups environmental and integrated alternatives resulted with wider range of possibilities of change than the economic, mainly for the targeted variables profitability, OM balance, and feed costs. When comparing the current dairy performance with the set of alternatives, farms showed the best result for minimizing $N$ balance with weights between 0.41 and 0.83 (SSE and FBM), and the worst performance was for maximizing OM balance with weights between -0.29 and 0.08 (FBE and SSI). The model showed that just re-allocating the current resources might represent by itself economic, social and/or environmental improvements for smallholder dairy farms.
\end{abstract}

Keywords: Multi-objective optimization; profitability; feeding costs; organic matter balance; nitrogen balance.

Published in Agricultural Systems 144, 22-32. doi:10.1016/j.agsy.2016.02.001 


\subsection{Introduction}

Livestock is an important economic activity employing 1.3 billion people worldwide and feeding 6.9 billion (Thornton, 2010; FAO, 2012). During the past 40 years livestock production increased annually by $2.3 \%$ thus staying ahead of the on average $1.7 \%$ population growth rate (FAO, 2006). The global demand for animal products is expected to increase by $25.7 \%$ for meat and by $17.5 \%$ for dairy products by 2030 (FAO, 2006). In Mexico, milk production increased on average 1.2\% annually; less than the 1.4\% increase in the demand of dairy products (INEGI, 2010; SAGARPA, 2010). As a consequence, Mexico continued to import milk and dairy products, and became the worldwide largest importer of dry milk with a share of $23 \%$ of the market (SE, 2012). On the domestic market, the liberalization of imports from the USA as part of the North American Free Trade Agreement (NAFTA) resulted in a decline in milk prices, which had negative consequences for the revenues of smallholder dairy farmers (Lara-Covarrubias et al., 2003; Espinoza-Ortega et al., 2005; Cortez-Arriola et al., 2015). Aguilar and López (2006) identified a number of key threats for the sustainability of dairy farmers in Mexico, including poor production infrastructure, degradation of natural resources, scarce financial resources, lack of organization and vertical integration, and slow adoption of technologies that allow adaptation to changing conditions. To capture the opportunities offered by the increasing demand for dairy products smallholders will need to produce at less cost per unit product. Such sustainable intensification of smallholder farms requires alternatives that improve farm profitability and productivity by making more efficient use of on-farm production resources and in the process curtailing negative impacts on the environment.

The need to re-think dairy production systems is mirrored at the global scale where livestock productivity increased as a result of improvements in feed, feeding regimes, animal characteristics and management, fuelled by global markets (e.g. Vishwanath, 2003; Naylor et al., 2005; Hazell and Wood, 2008; Thornton, 2010). Although productivity per animal increased enormously, so did the dependence of the sector on external inputs of feeds, mineral fertilizers, antibiotics and water, resulting in low resource use efficiencies (e.g., Van Keulen and Breman, 1990; Armstrong et al., 2000; Gourley et al., 2012). Alternative intensification pathways will need to improve not only management of the key components of the farm system but particularly focus on their interactions, since these provide leverage points for systemic performance improvement (Hutching and Nordblom, 2011). Whole farm models provide a powerful means to theoretically test alternative intensification pathways under a diversity of possible future scenarios (Sterk et al., 2007; Whitbread et al., 2010; Hutching and Nordblom, 2011).

Various computational tools have been developed to simulate and explore alternatives that can inform re-design of farming systems. These tools have evolved from models for the analysis of specific farm components and indicators, such as feed balances, economic efficiency and nutrient dynamics, to 
models for integrated farming systems analysis and redesign (Westphal et al., 1989; Herny et al., 1995; DeLorenzo and Thomas, 1996; Thornton and Herrero, 2001; Tittonell et al., 2007; Groot et al., 2012). Use of model-based decision support tools has not been common practice in México, particularly for livestock systems. Castelán-Ortega et al. (2003) and Val-Arreola et al. (2004, 2006) developed models to help farmers and technicians in decision making for smallholder dairy systems in central Mexico. However, the lack of connection between sub-models in the model proposed by Castelán-Ortega et al. (2003) and the level of specificity in the model proposed by Val-Arreola et al. (2004, 2006) reduce their usefulness for integrative analysis. Here we propose the use of the integrative farm system model FarmDESIGN which is part of the COMPASS framework (Groot et al., 2012) to explore tradeoffs between farmer objectives and strategies to inform the re-design of smallholder dairy farm systems in the municipality of Marcos Castellanos, Michoacán, Mexico.

We analyzed alternative intensification options for case study smallholder farm systems that represent family-based (FB) and semi-specialized (SS) systems. Both categories of systems are characterized by low productivity, negative net margin per unit of milk produced, high production costs due to concentrate purchases, inefficient on-farm nutrient cycling and negative environmental externalities (Cortez-Arriola et al., 2014; Cortez-Arriola et al., 2015). Our objectives were: a) to explore management alternatives that enhance farm economic performance, while improving resource use efficiency and reducing negative environmental impacts, and b) to analyze tradeoffs and synergies between profitability, soil organic matter balance, nitrogen balance, labor balance and feed costs to improve sustainability in smallholder farm systems.

\subsection{Materials and methods}

\subsubsection{Case study area}

The municipality of Marcos Castellanos is located in the north-west of Michoacán State $\left(19^{\circ}\right.$ northern latitude and $103^{\circ}$ west longitude) at altitudes between 1,500 and 2,400 masl. The area of this municipality is 23,285 ha, $86 \%$ of which is grazing land mainly composed of native grass species, and $12 \%$ is cropland mostly for maize forage production (Secretaría de Gobierno, 2010). The climate is temperate with a rainy season between June and October. Precipitation and temperature averages are $798 \mathrm{~mm}$ and $18.9{ }^{\circ} \mathrm{C}$, respectively. Chromic and pellic Vertisols are the dominant soil type, in association with Luvisols, Inceptisols, Phaeozems, and Andosols (SEMARNAT, 2003).

\subsubsection{Dairy farm systems characterization}

Model-based explorations were conducted for six pilot farms within the municipality of Marcos Castellanos, three farms representing family-based (FB) systems, the other three semi-specialized (SS) systems. Within each category farm were selected according to current production intensity level 
according to a typology developed for the region (Cortez-Arriola et al., 2015): intensive (FBI and SSI, with more than 1.2 LU per ha), medium-intensive (FBM and SSM, between 0.8 and 1.2 LU per ha), and extensive (FBE and SSE, less than $0.8 \mathrm{LU}$ per ha). Basic information describing farms size and composition, labor use, livestock, productivity, and diet composition is included in Table 4.1.

Soil sampling and runoff measurements were carried out during the rainy season in two selected farms to determine soil physical and chemical properties and soil losses in grazing and cropping lands. Following the Benchmark sampling design (Pennock et al., 2006), two 30 X 30 m plots in grazing land and two in cropping land in each farm were monthly sampled. One soil sample was constituted by 30 subsamples randomly taken in each plot with the soil sampler buried up to $25 \mathrm{~cm}$ deep. Beside every plot, three runoff plots $1 \mathrm{~m} \times 5 \mathrm{~m}$ were installed to capture and to measure runoff after each precipitation event (Hudson, 1993). On all fields in each farm soil sampled was analyzed to establish soil bulk density, nitrogen $(\mathrm{N})$, phosphorus $(\mathrm{P})$, potassium $(\mathrm{K})$ and organic $\mathrm{C}$ content. Runoff and soil loss samples were analyzed for N, P, K and organic C. Two weather stations Davis Vantage Pro2 ${ }^{\mathrm{TM}}$

Table 4.1. Size, intensity, labor, productivity characteristics and ration composition of six dairy farms representing family-based (FB) and semi-specialized (SS) dairy farm systems in Marcos Castellanos, Michoacán, Mexico. Additional letters denote farming intensity: intensive (I), medium-intensive (M) and extensive (E).

\begin{tabular}{|c|c|c|c|c|c|c|}
\hline Variable & FBE & FBM & FBI & SSE & SSM & SSI \\
\hline Total area (ha) ${ }^{\mathrm{a}}$ & 57.2 & 46.7 & 23.6 & 95.1 & 132.8 & 23.6 \\
\hline Rangeland (ha) & 54.6 & 44.5 & 12.8 & 76.0 & 109.6 & 0 \\
\hline Improve pasture (ha) & 0.0 & 0.0 & 5.3 & 0.0 & 0.0 & 19.1 \\
\hline Cropland (ha) & 2.6 & 2.2 & 5.5 & 11.6 & 23.2 & 4.5 \\
\hline Cows (Nr) & 12 & 24 & 18 & 42 & 92 & 27 \\
\hline Heifers (Nr) & 8 & 14 & 15 & 22 & 56 & 13 \\
\hline Calves (Nr) & 4 & 7 & 7 & 11 & 28 & 6 \\
\hline Hired labor (Labor-day $\mathrm{y}^{-1}$ ) & 0 & 185 & 387 & 1110 & 1208 & 1000 \\
\hline Family labor (Labor-day $y^{-1}$ ) & 548 & 365 & 148 & 114 & 365 & 532 \\
\hline Stocking rate $\left(\mathrm{LU} \mathrm{ha}{ }^{-1}\right)^{\mathrm{b}}$ & 0.33 & 0.75 & 1.31 & 0.62 & 1.05 & 1.57 \\
\hline Milk production $\left(\mathrm{Mg} \mathrm{y}^{-1}\right)$ & 35.0 & 87.3 & 92.1 & 146.6 & 302.2 & 137.9 \\
\hline Forage maize yield (Mg DM ha-1) & 10.3 & 16.0 & 16.5 & 7.7 & 16.3 & 7.4 \\
\hline Concentrate in ration ( $\left.\mathrm{g} \mathrm{kg}^{-1} \mathrm{DMI}\right)$ & 396 & 367 & 529 & 343 & 286 & 331 \\
\hline Forage in ration ( $\left.\mathrm{g} \mathrm{kg}^{-1} \mathrm{DMI}\right)$ & 604 & 633 & 471 & 657 & 714 & 669 \\
\hline Forage from grazing in ration $\left(\mathrm{g} \mathrm{kg}^{-1}\right.$ & 492 & 268 & 162 & 271 & 207 & 222 \\
\hline DMI) & & & & & & \\
\hline
\end{tabular}

${ }^{a}$ Includes the effective land used for grazing and cropping.

${ }^{\mathrm{b}}$ Livestock unit (LU) is defined in Mexican terms as a $450 \mathrm{~kg}$ LW lactating cow with a calf younger than 7 months. 
were installed to record temperature $\left({ }^{\circ} \mathrm{C}\right)$ and rainfall $(\mathrm{mm})$ at 15 -minute intervals.

The pilot farms were visited every fortnight between July 2009 and June 2010 and information was collected on social, economic and environmental aspects, and on management of the crop and animal subsystems. The socio-economic information and types and quantities of inputs and outputs of the farms were collected every fortnight. For the animal subsystem, collected data pertained to herd structure, milk production and destination, body weight, dry matter intake (DMI), labor input, and sanitary and reproductive management. For the crop subsystem, the information measured and collected was related to forage production and utilization, and inputs and labor input, costs and allocation.

Samples of grazed and conserved forage and bought feedstuffs were analyzed for acid fiber detergent, N, P, K, carbon (C) and ash content. In samples of milk, feces and urine N, P, K, carbon (C) and ash content were established. Metabolizable energy (ME) content of feedstuffs was estimated through acid detergent fiber content using the equation ME = 3.412 - 0.0322 x ADF (Table 15.5 in NRC, 2001).

Some variables were estimated or obtained from the literature. Biological and non-symbiotic fixation were derived from Cleveland et al. (1999), considering that most of the grazing land consisted of native species. Atmospheric deposition of $\mathrm{N}$ was indirectly estimated according to Galloway et al. (2008), and P and K deposition were calculated as a function of the precipitation and deposition factors (Smaling and Fresco, 1993). Parameters to estimate DMI capacity, and ME and crude protein (CP) requirements per animal type in the herd were based on NRC standards (NRC, 1989, 2001). Nutrient requirements were computed to meet maintenance, growth, milk production, and pregnancy. ME requirements for milking cows were estimated using corrections for the local type of animals and local management conditions (Améndola, 2008).

The depreciation costs of infrastructure and equipment were estimated with Equation 4.1 (cf. Wadsworth, 1997).

$$
\mathrm{AD}=(\mathrm{IV}+\mathrm{AIR}-\mathrm{RV}) / \mathrm{Y}
$$

Where:

$\mathrm{AD}=$ Annual depreciation (US\$ per year).

IV = Initial value (US\$).

AIR = Active interest rate (US\$).

$\mathrm{RV}=$ Residual value (US\$).

$\mathrm{Y}=$ Useful life (years).

The initial and residual values of infrastructure and equipment were defined based on prices on websites for second-hand equipment or on average prices in the region. The expected lifespan was 
defined based on the current condition of farm equipment and time in use. The active interest rate was based on rates listed by CEFP (2009). The opportunity cost of land was estimated as the average land rent in the study region. Economic value of family labor was estimated based on the salary of a locally available alternative occupation for each family member that worked on the farm.

\subsubsection{FarmDESIGN model}

\subsubsection{Model description}

The FarmDESIGN model is a static and exploratory model that quantifies farm productive, economic and environmental performance on an annual basis. In this study the model was used to generate alternative farm configurations that represent an improvement of current systems. The model employs an evolutionary algorithm to generate alternative configurations of agricultural production systems by adjusting farm components (crops, animals, manures) and inputs, and evaluating the consequences for productive, economic and environmental outcomes that can serve as constraints or objective variables based on Pareto-optimality (Groot et al., 2012).

The inputs required for the model can be grouped into: biophysical environment (soil and climate); socio-economics (costs, labor demand and prices); crops (diversity, production, nutrient composition, labor demand and costs); crop products (diversity, demand, costs, and nutrient composition; external feed sources); animals and herd composition (diversity, management, productivity, and nutrient requirements); animal products (diversity, destination, prices, and composition); manure types and degradation (production, management, and use efficiency); external sources of mineral nutrients (diversity, amounts, composition, costs, and use efficiency), and physical assets (buildings and machinery). A static farm balance model calculates the outcomes: flows of OM, C, N, P and K through and from the farm, the resulting nutrient balances, herd DMI and feed balance, the amount and composition of manure, a labor balance and economic results.

For the exploration process, management aspects of inputs (e.g. areas of crops, numbers of animals, milk production per animal, and fertilizer application rate) serve as decision variables. These are varied within predefined ranges by the optimization algorithm. Calculated farm outcomes can be constrained to manage the farm performance within desirable limits, for instance to avoid feed deficiencies or surpluses of nutrients, OM, and labor. Outcome variables can also serve as objectives that can be either minimized or maximized. The model utilizes a Pareto-based multi-objective evolutionary algorithm for optimization (see also Groot et al., 2010, 2012). A complete description of the model was presented by Groot et al. (2012).

\subsubsection{Decision variables}

The tactical farm choices can be selected as decision variables during optimization. These include the areas of cultivated crops (including feed crops), the destination of crop products (for instance use as 
feed, green manure, or exported from the farm; distribution of feed between the dry and the wet season) and management variables for the animal herd (animal numbers, productivity, replacement). An overview of decision variables used and the allowed ranges used for these variables during optimization for farm FBI can be found in Table 4.2 while the choice of constraints will be explained in the next section.

\subsubsection{Constraints and objectives}

Adjustments in decision variables lead to changes in model outcomes. Outcomes can be selected as constraints that should be within a given range, or as objectives that can be minimized or maximized. Important constraints relate to the feed balance: the deviation between demand and supply of energy and protein should be within narrow ranges to allow the production levels to be defined by animal numbers and corresponding productivity. Moreover, the DM supply to the animals cannot exceed the intake capacity. Other constraints are formulated for nutrient balances and to avoid mining of nutrients these balances should have values $>0 \mathrm{~kg} \mathrm{ha}^{-1}$. However, since $\mathrm{N}$ tends to be rather labile in natural systems some inherent losses should be anticipated. Therefore, the $\mathrm{N}$ soil balance was set to be $>20 \mathrm{~kg}$ $\mathrm{ha}^{-1}$ to ensure proper farm functioning. Changes in the use of regular, skilled labor on the farms was limited to a maximum increase of $30 \%$ and a maximum decline of $50 \%$. An overview of selected constraints and their allowed ranges for farm FBI is presented in Table 4.2.

Five outcome variables were selected as objectives on the basis of the farm diagnosis performed by Cortez-Arriola et al. (2015). This selection was such that it targeted improving the social, economic and environmental aspects of the farms and farmers' livelihoods, by:

- Maximizing the profitability thus increasing economic performance.

- Minimizing the feed costs thereby enhancing self-sufficiency of the farming system.

- Minimizing the labor balance thereby freeing farm labor, for alternative activities.

- Minimizing the $\mathrm{N}$ balance in order to reduce emission losses and environmental impacts.

- Maximizing the OM balance, thereby enhancing inherent soil fertility and water retention.

\subsubsection{Exploration procedure}

The optimization process was run for 2000 iterations to ensure that stable outcomes per run could be attained. The other parameters for the evolutionary algorithm were used in their default setting, which Groot et al. (2010; 2012) found to be robust: the probability of crossover (CR=0.85) and the amplitude of mutations $(\mathrm{F}=0.15)$. The multiplication factor $(\mathrm{M})$ was adjusted to obtain a solution set of 600 alternatives per farm (the number of solutions is determined by multiplying $\mathrm{M}$ with the number of decision variables selected). The original configuration of the farms was used as a starting point during 
optimizations, and constituted $20 \%$ of the initial population. The rest of the population (80\%) was randomly generated allowed farm configurations (Groot et al., 2010, 2012).

Table 4.2. Decision variables (inputs and outcomes of the model) and constrains defined for the multiobjective optimization at the FBI farm.

\begin{tabular}{|c|c|c|c|}
\hline Decision variable & Original & Minimum & Maximum \\
\hline \multicolumn{4}{|l|}{ Decision variables } \\
\hline Farm rangeland (ha) & 12.83 & 7.83 & 12.83 \\
\hline Farm pasture (ha) & 5.34 & 1.34 & 5.34 \\
\hline Farm cropland (ha) & 5.46 & 1.50 & 5.46 \\
\hline Concentrate 1 (kg DM) & $1690(1)$ & $0(0)$ & $40000(1)$ \\
\hline Concentrate 2 (kg DM) & $37860(0.59)$ & $0(0)$ & $40000(1)$ \\
\hline Milk (kg DM) & 0 & $0(0.40)$ & $320(0.60)$ \\
\hline Milk replacer (kg DM) & $224(0.49)$ & $87(0.40)$ & $225(0.60)$ \\
\hline Whey (kg DM) & $1427(1)$ & $0(0.55)$ & $1427(1)$ \\
\hline $\begin{array}{l}\text { Concentrate for calves (kg } \\
\text { DM) }\end{array}$ & $451(0.41)$ & $250(0.40)$ & $500(0.60)$ \\
\hline $\begin{array}{l}\text { Concentrate for weaning (kg } \\
\text { DM) }\end{array}$ & $541(0.41)$ & $540(0.40)$ & $1600(0.60)$ \\
\hline $\begin{array}{l}\text { Concentrate for heifers (kg } \\
\text { DM) }\end{array}$ & $9441(0.58)$ & $0(0)$ & $15000(1)$ \\
\hline Soybean hulls (kg DM) & $1806(0.35)$ & $0(0)$ & $8000(1)$ \\
\hline Wheat bran (kg DM) & $3994(0.17)$ & $0(0)$ & $8000(1)$ \\
\hline Alfalfa hay (kg DM) & $3426(1)$ & $0(0)$ & $10000(1)$ \\
\hline Chickpea straw (kg DM) & $777(0)$ & $0(0)$ & $15000(1)$ \\
\hline Maize stover (kg DM) & $6255(0.38)$ & $0(0)$ & $15000(1)$ \\
\hline Maize silage (kg DM) & $23025(0.84)$ & $0(0)$ & $30000(1)$ \\
\hline Calves (Nr) & 7 & 5 & 9 \\
\hline Heifers (Nr) & 15 & 11 & 19 \\
\hline Cows (Nr) & 18 & 14 & 23 \\
\hline \multicolumn{4}{|l|}{ Constraints } \\
\hline Farm area (ha) & 23.6 & 15 & 23.7 \\
\hline Intake in rainy season (\%) & -27 & - & 0 \\
\hline ME in rainy season (\%) & -3 & -10 & 0 \\
\hline $\mathrm{CP}$ in rainy season (\%) & -5 & -6 & 10 \\
\hline Intake in dry season (\%) & -32 & - & 0 \\
\hline ME in dry season (\%) & 7 & -10 & 10 \\
\hline CP in dry season (\%) & -11 & -12 & 10 \\
\hline Profit (US\$) & 4618 & -773 & 77250 \\
\hline Feed costs (US\$) & 27162 & 9460 & 31982 \\
\hline OM balance $\left(\mathrm{kg} \mathrm{ha}^{-1}\right)$ & -188 & -200 & - \\
\hline $\mathrm{N}$ balance $\left(\mathrm{kg} \mathrm{ha}^{-1}\right)$ & 95 & 20 & - \\
\hline $\mathrm{P}$ balance $\left(\mathrm{kg} \mathrm{ha}^{-1}\right)$ & 27 & 0 & - \\
\hline $\mathrm{K}$ balance (kg ha $\left.{ }^{-1}\right)$ & 12 & 0 & - \\
\hline Labor balance (h) & 1788 & 800 & 3500 \\
\hline
\end{tabular}




\subsubsection{Analysis of alternatives: functional groups}

Following optimization, we determined functional groups that demonstrated a coherent strategy of farm adjustment within each population of alternatives using Principal Component Analysis (PCA) and cluster analysis. The cluster analysis was conducted by agglomerative hierarchical clustering, followed by a centroid analysis (K-means). The approach was adapted from the methodology described by Härdle and Hlávka (2007).

The analysis included the five objectives plus herd size and percentage of cows in herd, total DMI, and the proportions of fodders, concentrates, own conserved maize forage and forage from grazing land in the diet. Before starting the analysis, the variables were transformed using unbiased standard deviations. In the principal component analysis, we used a nonparametric Spearman correlation test at the $5 \%$ significance level. The first six factors identified by principal component analysis, explaining around of $99 \%$ of the total variability were then used in the cluster analysis. This analysis was done using Euclidean distance to calculate the dissimilarity distance and Ward's agglomeration method. The centroids obtained as results of the agglomerative hierarchical clustering were used to carry out the K-means analysis, using a Determinant criterion and 500 iterations. The analyses were performed with XLSTAT software.

\subsubsection{Relative performance of pilot farms and functional groups}

The performance of the original pilot farms and the functional groups was calculated relative to the potential options obtained in the solution set from the optimization, using the approach presented by Mandryk et al. (2013). Weights for the five objectives were calculated and used to derive the relative performance of pilot farms and solutions per functional group. The objective values of the solutions were compared with the extreme (ideal and anti-ideal) values in the solution set with the following formula (Nordström et al., 2009):

$$
W_{j}^{o}=\left(O^{r *}-O_{j}^{r}\right) /\left(O^{r *}-O_{*}^{r}\right)
$$

Where $W_{j}^{o}$ is the weight for a specific objective derived from a solution $j ; O^{r *}$ and $O_{*}^{r}$ are the ideal and anti-ideal values, respectively, for the $r^{\text {th }}$ objective within the set of alternatives; $O_{j}^{r}$ is the outcome that corresponds to the $j^{\text {th }}$ alternative when it is evaluated according to the $r^{\text {th }}$ objective. Based on this approach, all the weights occur in a range between 0 (ideal) and 1 (anti-ideal). In addition, we reversed the ideal and anti-ideal values with 1 becoming an ideal value instead of 0 . For the functional groups the means of the weights of solutions per group and per objective were calculated. 


\subsection{Results}

\subsubsection{Classification of alternatives into functional groups}

The two first principal components (PCs) explained between 78.2 and 95.0\% of the variance among the alternatives (Table 4.3), indicating homogeneity within the solution sets. PC1 explained between 53.2 and $74.2 \%$ of the overall variance (Figure 4.1). For five of the six case study farms, PC1 was defined primarily by the variables DMI, feed costs, and DMI from grazing. PC2 explained between 19.2 and $30.5 \%$ of the variance, correlated with profitability, the percentage of cows in the herd and the proportion of concentrate and forage in the ration (Table 4.3). Three functional groups were identified within this solution set (Figure 4.1), which were clearly differentiated in terms of their centroids and their respective confidence ellipses (95\% of confidence interval). The functional groups differed in the weights for each of the objective variables (Table 4.4). The groups were labelled as 'economic' for alternatives that prioritized profitability, 'environmental' for alternatives that prioritized OM balance, and 'integrated' for alternatives that combined minimization of labor used (social variable), with reducing $\mathrm{N}$ balance (environment) and feeding costs (economic). The 'economic' group of alternatives had the highest percentage of lactating cows in the herd for all farms, and sold the largest amount of forage produced in four out of five farms that produced and sold this

Table 4.3. Contribution (\%) of the variables to principal components (PC) and the variance explained (\%) in the multivariate analysis per dairy farm representing family-based (FB) and semi-specialized (SS) dairy farm systems in Marcos Castellanos, Michoacán, Mexico. Additional letters denote farming intensity: intensive (I), medium-intensive (M) and extensive (E).

\begin{tabular}{lrrrrrrrrrrrr}
\hline \multirow{2}{*}{ Variable } & \multicolumn{2}{c}{ FBE } & \multicolumn{1}{c}{ FBM } & \multicolumn{2}{c}{ FBI } & \multicolumn{2}{c}{ SSE } & \multicolumn{2}{c}{ SSM } & \multicolumn{2}{c}{ SSI } \\
& PC1 & PC2 & PC1 & PC2 & PC1 & PC2 & PC1 & PC2 & PC1 & PC2 & PC1 & PC2 \\
\hline \multirow{2}{*}{ Variance explained } & 63.8 & 25.3 & 66.9 & 24.3 & 53.2 & 30.5 & 69.6 & 20.3 & 74.2 & 20.8 & 59.0 & 19.2 \\
Herd size & 10.9 & 0.4 & 9.3 & 2.5 & 11.4 & 1.5 & 8.5 & 5.2 & 9.7 & 0.9 & 10.6 & 0.2 \\
Cows in herd & 0.0 & 21.0 & 5.6 & 3.6 & 0.1 & 13.9 & 2.2 & 17.7 & 3.6 & 19.2 & 1.2 & 24.4 \\
Conserved forage in ration & 12.0 & 0.0 & 9.4 & 4.2 & 6.6 & 10.0 & 9.7 & 1.8 & 6.6 & 9.6 & 5.9 & 12.5 \\
Forage produced in ration & 12.0 & 0.0 & 9.2 & 4.6 & 1.2 & 13.7 & 6.3 & 8.8 & 9.0 & 3.1 & 1.5 & 18.8 \\
Forage grazed in ration & 11.8 & 0.2 & 11.0 & 0.6 & 13.1 & 0.2 & 10.8 & 0.7 & 8.9 & 4.7 & 12.2 & 0.0 \\
Total forage in ration & 0.1 & 23.4 & 0.5 & 28.3 & 0.1 & 21.4 & 3.9 & 20.8 & 9.5 & 1.6 & 6.5 & 2.7 \\
Concentrates in ration & 0.1 & 23.4 & 0.5 & 28.3 & 0.1 & 21.4 & 3.9 & 20.8 & 9.5 & 1.6 & 6.5 & 2.7 \\
DM intake & 12.0 & 0.0 & 11.1 & 0.3 & 13.8 & 0.2 & 10.8 & 0.7 & 8.9 & 4.6 & 10.0 & 2.8 \\
OM balance & 10.9 & 1.4 & 11.1 & 0.2 & 12.9 & 0.6 & 10.5 & 0.1 & 5.4 & 15.3 & 12.2 & 0.4 \\
Profitability & 3.0 & 20.2 & 9.3 & 2.5 & 6.2 & 7.3 & 5.8 & 9.9 & 0.2 & 33.8 & 5.2 & 20.8 \\
N balance & 9.5 & 0.5 & 8.4 & 7.2 & 13.5 & 0.3 & 9.4 & 4.0 & 10.0 & 0.8 & 11.2 & 0.1 \\
Feeding costs & 11.9 & 0.2 & 10.9 & 0.8 & 13.6 & 1.0 & 10.6 & 1.3 & 9.1 & 4.3 & 11.8 & 0.1 \\
Labor balance & 6.0 & 9.1 & 3.8 & 16.9 & 7.3 & 8.5 & 7.7 & 8.0 & 9.7 & 0.7 & 5.2 & 14.4 \\
& & & & & & & & & & &
\end{tabular}


product (Table 4.5). The 'environmental' group of alternatives was characterized by having the largest milk production per hectare, and greatest stocking rates, DMI, N surpluses, ration costs, and labor needs. The 'integrated' group included those alternatives that reduced ration costs and dependence on external inputs, and typically included more forage and grazing in the ration. In general, 'integrated' alternatives were most predominant in FBE, FBI, SSE and SSI while economic ones were less abundant in FBE, SSE, SSM and SSI.

Table 4.4. Weights for objective variables established for the multi-objective optimization of dairy farm systems (family-based, FB, and semi-specialized, SS), and groups of alternatives identified in the multivariate analysis. Additional letters denote farming intensity: intensive (I), medium-intensive (M) and extensive (E).

\begin{tabular}{|c|c|c|c|c|c|c|}
\hline System & Classification & Profitability & OM balance & $\mathrm{N}$ balance & Labor balance & Feeding costs \\
\hline \multirow{3}{*}{ FBE } & Economic & 0.31 & 0.74 & 0.37 & 0.75 & 0.31 \\
\hline & Environmental & 0.77 & 0.19 & 0.63 & 0.78 & 0.70 \\
\hline & Integrated & 0.67 & 0.77 & 0.22 & 0.25 & 0.20 \\
\hline \multirow{3}{*}{ FBM } & Economic & 0.28 & 0.79 & 0.32 & 0.35 & 0.21 \\
\hline & Environmental & 0.79 & 0.13 & 0.71 & 0.76 & 0.78 \\
\hline & Integrated & 0.65 & 0.40 & 0.39 & 0.31 & 0.46 \\
\hline \multirow{3}{*}{ FBI } & Economic & 0.32 & 0.73 & 0.72 & 0.73 & 0.72 \\
\hline & Environmental & 0.72 & 0.13 & 0.72 & 0.73 & 0.72 \\
\hline & Integrated & 0.71 & 0.39 & 0.38 & 0.17 & 0.34 \\
\hline \multirow{3}{*}{ SSE } & Economic & 0.16 & 0.65 & 0.56 & 0.59 & 0.46 \\
\hline & Environmental & 0.78 & 0.22 & 0.68 & 0.59 & 0.69 \\
\hline & Integrated & 0.50 & 0.74 & 0.28 & 0.15 & 0.20 \\
\hline \multirow{3}{*}{ SSM } & Economic & 0.18 & 0.66 & 0.52 & 0.61 & 0.47 \\
\hline & Environmental & 0.57 & 0.10 & 0.73 & 0.80 & 0.69 \\
\hline & Integrated & 0.57 & 0.56 & 0.25 & 0.22 & 0.29 \\
\hline \multirow{3}{*}{ SSI } & Economic & 0.25 & 0.57 & 0.39 & 0.69 & 0.34 \\
\hline & Environmental & 0.63 & 0.24 & 0.68 & 0.63 & 0.61 \\
\hline & Integrated & 0.38 & 0.74 & 0.24 & 0.18 & 0.18 \\
\hline
\end{tabular}


Table 4.5. Main variables that characterize the groups (economic, environmental and integrated) obtained in the multivariate analysis and the family-based and semi-specialized dairy farm systems of Marcos Castellanos, Michoacán, Mexico. ${ }^{a}$

\begin{tabular}{|c|c|c|c|}
\hline Variable & Economic & Environmental & Integrated \\
\hline Profitability (US\$) & $>$ & & \\
\hline Cows in herd (\%) & $>$ & & \\
\hline Forage sold (Mg DM) & $>$ & & \\
\hline Milk production $\left(\mathrm{kg} \mathrm{ha}^{-1} \mathrm{y}^{-1}\right)$ & & $(>)$ & \\
\hline OM balance (kg ha $\left.{ }^{-1}\right)$ & & $>$ & \\
\hline DM intake (kg) & & $>$ & \\
\hline Ration cost (US\$ kg) & & $>$ & $(<)$ \\
\hline Stocking rate $\left(\mathrm{LU} \mathrm{ha}^{-1}\right)$ & & $(>)$ & \\
\hline Ext. dependence (kg DM ha $\left.{ }^{-1}\right)$ & $<$ & $(>)$ & $(<)$ \\
\hline Labor balance (h) & & $(>)$ & $<$ \\
\hline $\mathrm{N}$ balance (kg ha $\left.{ }^{-1}\right)$ & & $>$ & $(<)$ \\
\hline Forage DMI $\left(\mathrm{g} \mathrm{kg}^{-1}\right)$ & & & $(>)$ \\
\hline Grazing DMI (g kg $\left.{ }^{-1}\right)$ & & & $(>)$ \\
\hline Conserved forage DMI $\left(\mathrm{g} \mathrm{kg}^{-1}\right)$ & & $(>)$ & \\
\hline
\end{tabular}

\subsubsection{Exploration of trade-offs and synergies}

Figure 4.2 presents the functional groups for each pair of the five objectives. The integrated group exhibited a high degree of synergy between high profits and low feeding costs, and between low feeding costs and low $\mathrm{N}$ balance, as compared with both the 'economic' and 'environmental' groups. Tradeoffs existed between the objectives increasing soil OM balance and reducing feed costs, and between $\mathrm{OM}$ balance and $\mathrm{N}$ balance due to the carbon and nutrient transfers through manure application as practiced in most alternatives. Figure 4.3 presents the relationship between four of the five objectives (profit, feeding costs, soil organic matter and $\mathrm{N}$ balance), which showed some relationship between them, and four key variables, which had high correlation with at least one of the objective variables. Positive correlations were found between soil OM balance ( $\mathrm{kg} \mathrm{ha}^{-1}$ ) with the paramethers feed intake ( $\left.k g \mathrm{DM} \mathrm{ha}{ }^{-1}\right)$, external dependence ( $\mathrm{kg} \mathrm{DM} \mathrm{ha}{ }^{-1}$ ), and stocking rates ( $\left.\mathrm{LU} \mathrm{ha}^{-1}\right)$. Profitability was closely linked to the percentage of lactating cows in the herd.

Although such synergies and tradeoffs varied to some degree across farm types, the results of these model explorations confirm the trends we observed in the field. An increase in soil carbon levels 
(reflected in positive OM balances) tends to occur in more intensive systems with high stocking rates and consequently more feed intake per ha and more manure production, when a large part of the feed is imported from outside the farm (dependence on external sources). In these more intensive systems $\mathrm{N}$ surplusses and losses are also greater. Higher profits are attained when the proportion of productive
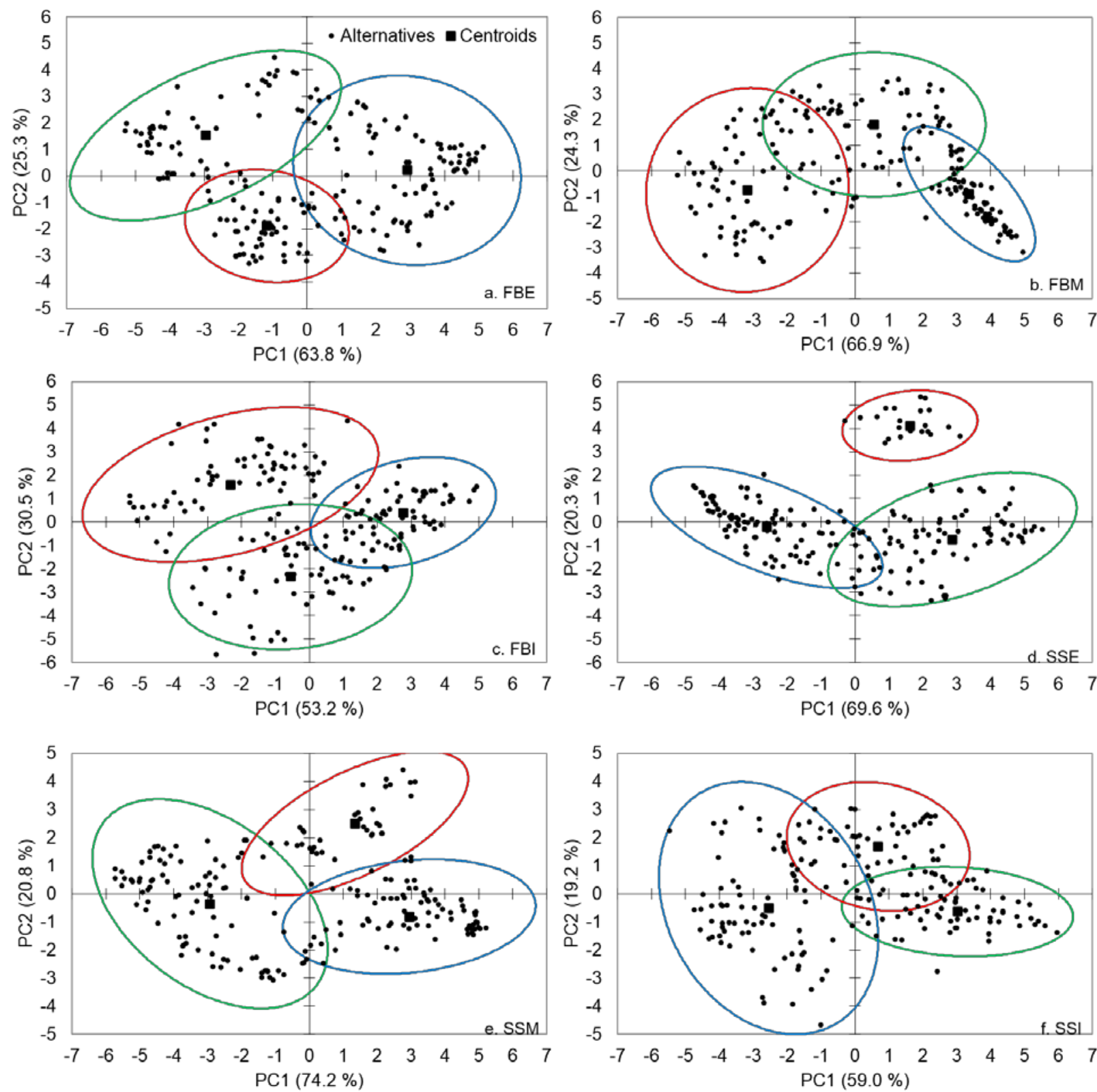

Figure 4.1. Grouping of alternative farming systems based on the principal components (PC, first two axes) of the multivariate analysis. The dairy farm systems analyzed correspond to family-based (FB) and semi-specialized (SS), as a function of production intensity expressed in stocking rate ( $\mathrm{LU} \mathrm{ha}^{-1}$ ). Additional letters I, M and $\mathrm{E}$ denote intensive, medium-intensive and extensive, respectively (see text). The confidence ellipses correspond to a 95\% confidence interval, and differentiate groups: economic (red), environmental (blue) and integrated (green). 

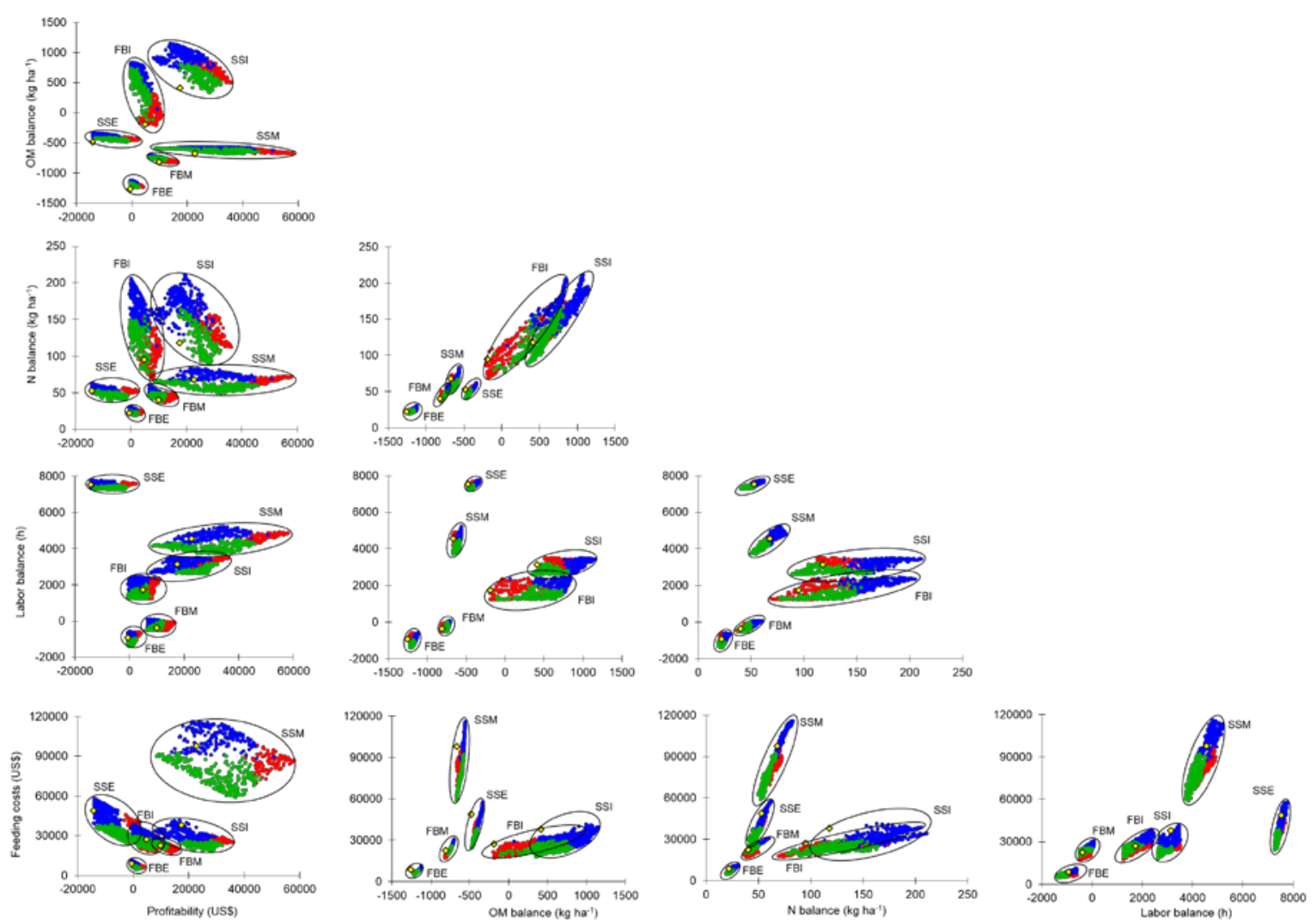

Figure 4.2. Relations between objective variables for six categories of dairy farming systems in North-west Michoacán, Mexico. Current farm performance is indicated by the yellow diamond. Within each point cloud red dots represent economic group, blue dots environmental group, and green dots integrated group.

milk cows in the herd is larger. The sets of alternatives generated through model exploration indicate the range of opportunities for change of the current farm systems. Overall, intensive systems either family-based or semi-specialised, and particularly the larger farms had the broadest range of opportunities for change through profit maximization, through soil fertility improvement, or through reduction of nutrient surpluses. The 'environmental' and 'integrated' functional groups exhibited broader ranges of possibilities for change than the 'economic' one through larger variation in profit levels, soil OM balances and feed costs. 

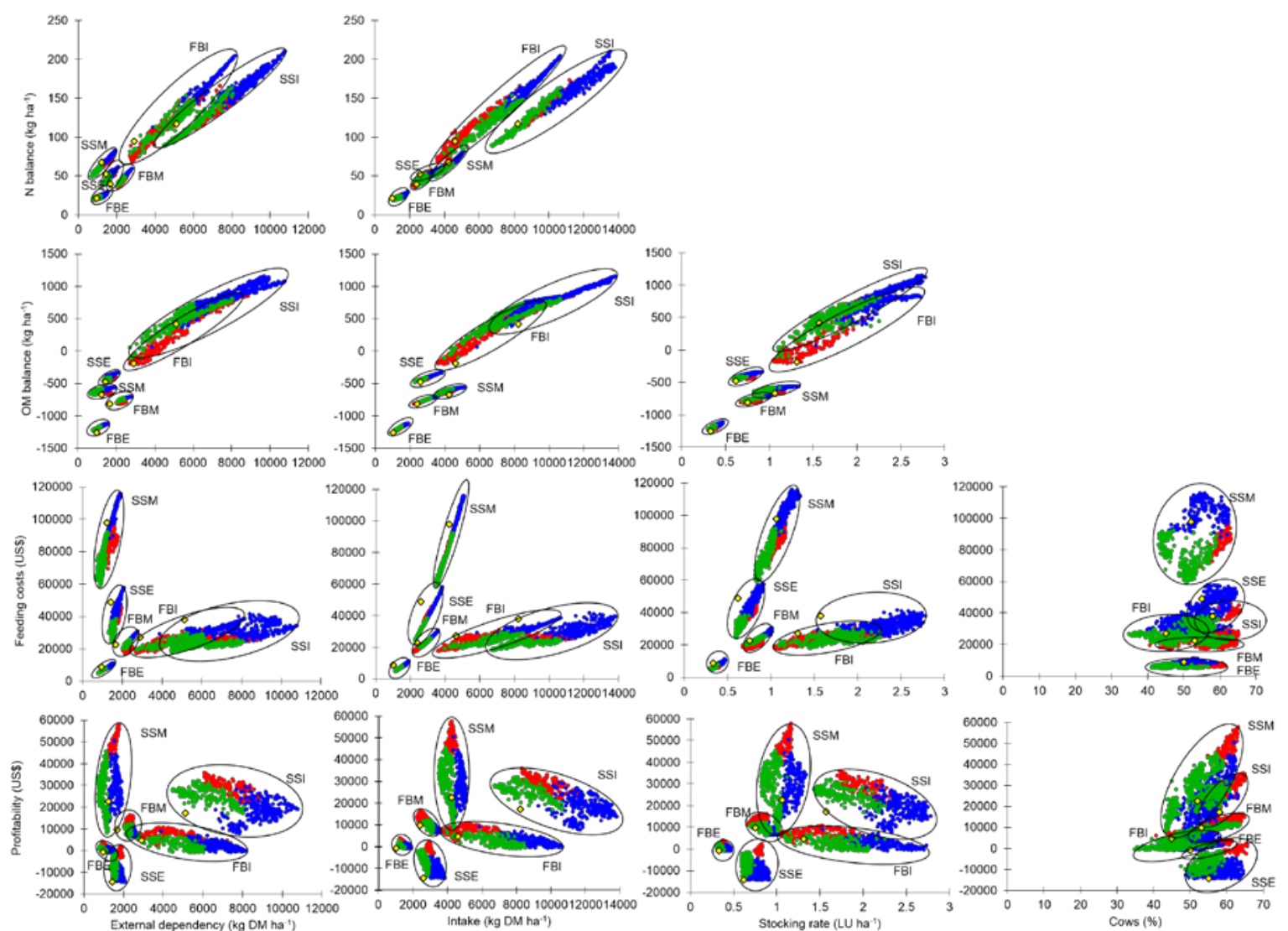

Figure 4.3. Relation between objective variables (y-axes) and key decision variables (x-axes) for six categories of dairy farming systems in North-west Michoacán, Mexico. These key decision variables had significant correlation in the PCA analysis with at least one objective variable. Current farm performance is indicated by the yellow diamond. Within each point cloud red dots represent economic group, blue dots environmental group, and green dots integrated group.

\subsubsection{Current farm performance}

We compared current farm performance against the set of alternatives that resulted from the explorations and estimated its relative performance using equation 2 . The intensive family-based farm (FBI) had the best relative performance in terms of profitability; the score 0.47 estimated for this farm indicates that $47 \%$ of the alternatives generated by the model were less profitable than the current farm configuration. The FBM and the SSI scores were 0.35 and 0.34 , respectively (Figure 4.4). The original FBI farm derived its income from the sales of milk and maize forage, whereas the main revenues of FBM and SSI stemmed from selling milk and cows, and by on-farm processing and direct marketing, respectively. All current farming systems performed poorly in terms of soil OM balance compared to the model exploration results, whereas there was less scope for improvement in nitrogen and labor balances (Figure 4.4). 


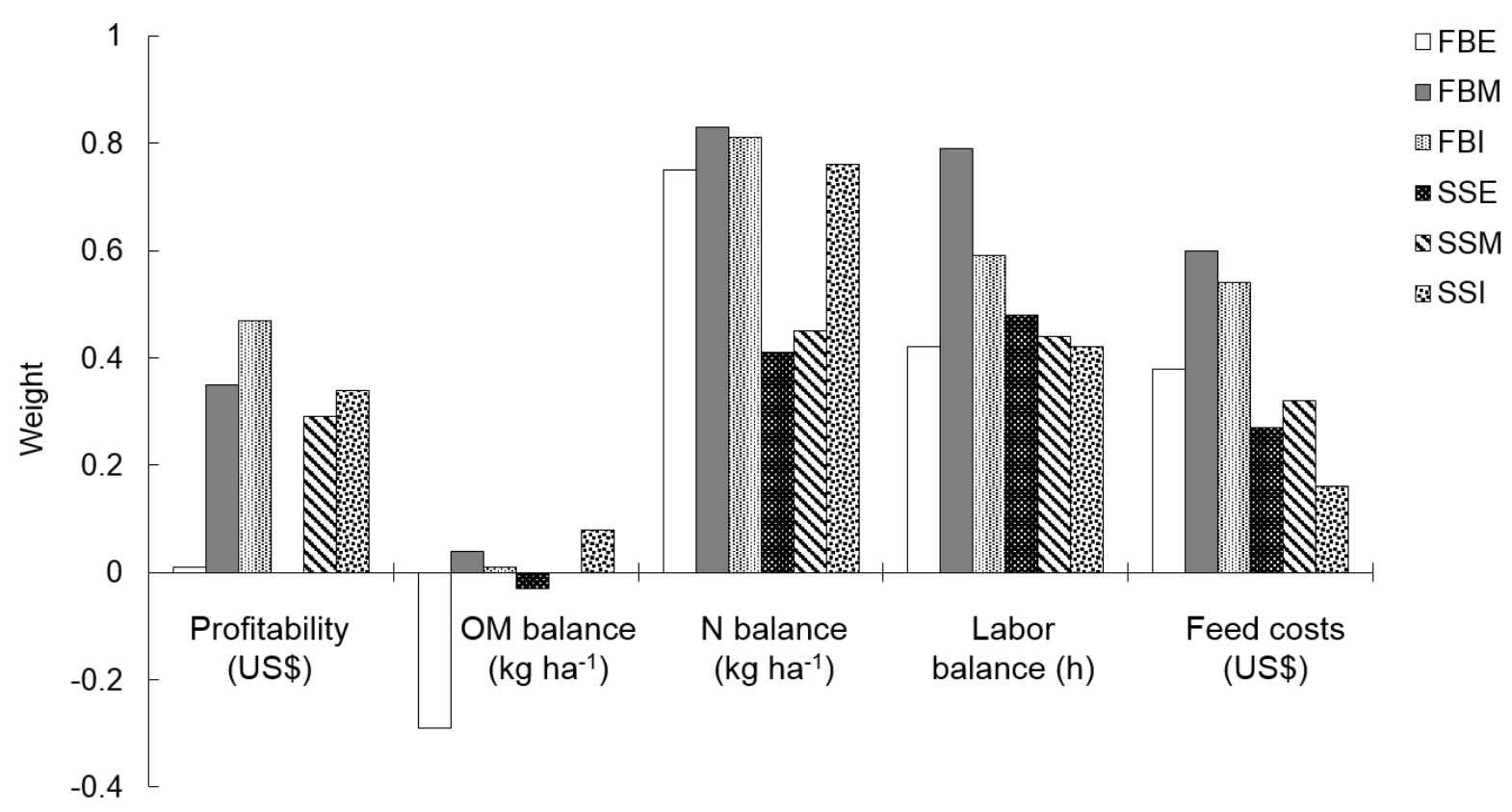

Figure 4.4. Assessment results of the current farm performance based on the weights per objective variable, considering the highest and the lowest values of the set of alternatives got in the multiobjective optimization in dairy farm systems. FB denotes family-based, and SS semi-specialized dairy systems. Additional letters denote farming intensity: intensive (I), medium-intensive (M) and extensive (E).

The current medium-intensive family-based farm (FBM) exhibited better performance than the other current farms in terms of minimizing labor use, $\mathrm{N}$ balance and feed costs $(0.83,0.79$, and 0.60 , respectively), whereas the semi-specialized farms SSE and SSI did worst. Considering the five objectives simultaneously, current management on the FBM farm had the highest average performance score, followed by the semi-specialized SSM farm.

Based on the performance scores we identified the best alternatives per farm system type (Tables 4.6 and 4.7 for family-based and semi-specialized, respectively), including the ration composition per farm type and external dependency of feeding. The alternatives resulting from the model explorations in the 'economic' functional group had increased their income by increasing herd size, the proportion of productive cows in the herd, stocking rates, milk production, and off-farm sale of forage produced, while changing the diet composition by reducing the use of concentrates and introducing cost-effective feedstuff alternatives. When maximizing the soil OM balance, the environmental alternatives of intensive farm systems (FBI and SSI) would have the greater impact on soil OM accumulation as compared with the current performance (1000 and $750 \mathrm{~kg} \mathrm{ha}^{-1}$, respectively) (Tables 4.6 and 4.7, and Figure 4.2). Soil OM balances improved in all systems under this set of alternatives due to increased stocking rates and consequently higher manure availability, although in extensive and medium- 
Table 4.6. Characterization of the best alternatives for the groups: economic, environmental and integrated alternatives of the family-based dairy farm systems in Marcos Castellanos, Michoacán. The selection of the best alternative per group and system was based on the larger value of the weights estimated according to Nordström et al. (2009). The best 'integrated' alternative was based on the combination of greatest values for labor balance, $\mathrm{N}$ balance, and feed costs.

\begin{tabular}{|c|c|c|c|c|c|c|c|c|c|}
\hline \multirow{2}{*}{ Variable } & \multicolumn{3}{|c|}{ Family Based, extensive } & \multicolumn{3}{|c|}{$\begin{array}{l}\text { Family Based, medium- } \\
\text { intensive }\end{array}$} & \multicolumn{3}{|c|}{ Family Based, intensive } \\
\hline & Econom. & Environ. & Integr. & Econom. & viron. & Integr. & Econom. & Environ. & Integr. \\
\hline \multicolumn{10}{|c|}{ Land use (ha) } \\
\hline Total area & 56.3 & 52.1 & 51.8 & 44.4 & 41.8 & 42.4 & 22.4 & 15.0 & 22.6 \\
\hline Rangeland & 54.3 & 50.1 & 49.8 & 42.2 & 39.6 & 40.2 & 11.8 & 7.8 & 12.1 \\
\hline Pasture & 0.0 & 0.0 & 0.0 & 0.0 & 0.0 & 0.0 & 5.2 & 1.7 & 5.3 \\
\hline Cropland & 2.0 & 2.0 & 2.0 & 2.2 & 2.2 & 2.2 & 5.4 & 5.4 & 5.3 \\
\hline
\end{tabular}

\section{Herd composition (Nr) and stocking rate $\left(L U \mathrm{ha}^{-1}\right)$}

$\begin{array}{lccccccccc}\text { Cows } & 15 & 15 & 9 & 28 & 28 & 23 & 23 & 23 & 14 \\ \text { Heifers } & 6 & 10 & 8 & 10 & 18 & 11 & 11 & 19 & 11 \\ \text { Calves } & 3 & 3 & 3 & 5 & 7 & 7 & 5 & 6 & 5 \\ \text { Stocking rate }^{\mathrm{a}} & 0.38 & 0.46 & 0.33 & 0.80 & 1.01 & 0.75 & 1.53 & 2.68 & 1.09\end{array}$

$\underline{\text { Ration composition and use of external foods }\left(\mathrm{kg} \mathrm{kg}^{-1} \mathrm{DMI}\right) \text { and its efficiency (US\$ } \mathrm{kg}^{-1} \text { milk) }}$

$\begin{array}{llllllllll}\text { Concentrate } & 0.16 & 0.19 & 0.19 & 0.37 & 0.35 & 0.27 & 0.54 & 0.51 & 0.35 \\ \text { Forage purchased } & 0.16 & 0.34 & 0.06 & 0.36 & 0.26 & 0.35 & 0.23 & 0.25 & 0.33 \\ \text { Maize forage produced } & 0.27 & 0.20 & 0.31 & 0.01 & 0.22 & 0.10 & 0.08 & 0.19 & 0.13 \\ \text { Grazing land (own) } & 0.00 & 0.00 & 0.00 & 0.03 & 0.02 & 0.03 & 0.14 & 0.05 & 0.19 \\ \text { Grazing land (rented) } & 0.41 & 0.28 & 0.44 & 0.24 & 0.16 & 0.25 & 0.00 & 0.00 & 0.00 \\ \text { External dependence of feed } & 0.73 & 0.80 & 0.69 & 0.96 & 0.76 & 0.82 & 0.77 & 0.76 & 0.68 \\ \text { Efficiency of external foods } & 0.15 & 0.25 & 0.20 & 0.20 & 0.30 & 0.24 & 0.23 & 0.33 & 0.27\end{array}$

$\underline{\text { Production and sale }}$

\begin{tabular}{|c|c|c|c|c|c|c|c|c|c|}
\hline Milk production (kg cow $\left.{ }^{-1} \mathrm{y}^{-1}\right)$ & 2628 & 2664 & 2810 & 3577 & 3614 & 3650 & 5074 & 5037 & 5183 \\
\hline Milk production $\left(\mathrm{Mg} \mathrm{y}^{-1}\right)$ & 39.5 & 40.2 & 25.2 & 100.4 & 101.4 & 84.3 & 116.6 & 116.1 & 72.4 \\
\hline Forage maize produced $\left(\mathrm{Mg} \mathrm{y}^{-1}\right)$ & 18.4 & 18.5 & 18.4 & 31.7 & 31.7 & 31.7 & 81.0 & 81.0 & 78.2 \\
\hline Forage maize sold ( $\left.\mathrm{Mg} \mathrm{y}^{-1}\right)$ & 0.0 & 0.0 & 0.0 & 30.8 & 0.0 & 15.0 & 71.2 & 51.1 & 66.7 \\
\hline
\end{tabular}

\section{$\underline{\text { Objectives }}$}

Profit (US\$)

OM balance $\left(\mathrm{kg} \mathrm{ha}^{-1}\right)$

$\mathrm{N}$ balance (kg ha ${ }^{-1}$ )

Feeding costs (US\$)

Labor balance (h)

$\begin{array}{rrr}3969 & 160 & 849 \\ -1223 & -1118 & -1221 \\ 24 & 26 & 22 \\ 6115 & 10151 & 4968 \\ -697 & -598 & -1389\end{array}$

$\begin{array}{rrrrrr}16373 & 6594 & 10282 & 10758 & 489 & 6012 \\ -809 & -704 & -769 & -29 & 842 & -104 \\ 44 & 59 & 41 & 110 & 201 & 80 \\ 19681 & 30320 & 20443 & 27399 & 38003 & 19243 \\ -105 & 21 & -498 & 2339 & 2379 & 1243\end{array}$

\footnotetext{
${ }^{\text {a }}$ Livestock unit (LU) is defined in Mexican terms as a $450 \mathrm{~kg} \mathrm{LW}$ lactating cow with a calf younger than 7 months.
} 
Table 4.7. Characterization of the best alternatives for the groups: economic, environmental and integrated alternatives of the semi-specialized dairy farm systems in Marcos Castellanos, Michoacán, Mexico. The selection of the best alternative per group and system was based on the higher value of the weights of the objective variable estimated according to Nordström et al. (2009). The best 'integrated' alternative was based on the combination of greatest values for labor balance, $\mathrm{N}$ balance, and feed costs.

\begin{tabular}{|c|c|c|c|c|c|c|c|c|c|}
\hline \multirow[t]{2}{*}{ Variable } & \multicolumn{3}{|c|}{ Semi-specialized, extensive } & \multicolumn{3}{|c|}{$\begin{array}{l}\text { Semi-specialized, medium- } \\
\text { intensive }\end{array}$} & \multicolumn{3}{|c|}{ Semi-specialized, intensive } \\
\hline & Econom. & Environ. & Integr. & Econom & nviron. & Integr. & Econom. & Environ. & Integr. \\
\hline \multicolumn{10}{|c|}{ Land use (ha) } \\
\hline Total area & 82.6 & 82.6 & 82.6 & 127.9 & 127.8 & 127.4 & 23.3 & 16.2 & 23.3 \\
\hline Rangeland & 71.0 & 71.0 & 71.0 & 104.8 & 104.7 & 104.7 & 0.0 & 0.0 & 0.0 \\
\hline Pasture & 0.0 & 0.0 & 0.0 & 0.0 & 0.0 & 0.0 & 18.8 & 14.1 & 19.1 \\
\hline Cropland & 11.6 & 11.6 & 11.6 & 23.1 & 23.1 & 22.7 & 4.4 & 3.8 & 4.3 \\
\hline
\end{tabular}

\section{Herd composition (Nr) and stocking rate $\left(L U \mathrm{ha}^{-1}\right)$}

$\begin{array}{lccccccccc}\text { Cows } & 50 & 50 & 32 & 115 & 115 & 70 & 30 & 29 & 23 \\ \text { Heifers } & 17 & 26 & 17 & 42 & 67 & 42 & 10 & 16 & 10 \\ \text { Calves } & 9 & 11 & 9 & 25 & 25 & 25 & 6 & 8 & 6 \\ \text { Stocking rate }\left(\mathrm{LU} \mathrm{ha}^{-1}\right)^{\mathrm{a}} & 0.83 & 0.91 & 0.59 & 1.16 & 1.32 & 0.82 & 1.73 & 2.74 & 1.44\end{array}$

Ration composition and use of external foods $\left(\mathrm{kg} \mathrm{kg}^{-1} \mathrm{DMI}\right)$ and its efficiency (US\$ $\mathrm{kg}^{-1}$ milk)

\begin{tabular}{|c|c|c|c|c|c|c|c|c|}
\hline Concentrate & 0.31 & 0.21 & 0.22 & 0.30 & 0.26 & 0.12 & 0.23 & 0.24 \\
\hline Forage purchased & 0.31 & 0.32 & 0.41 & 0.05 & 0.05 & 0.06 & 0.50 & 0.47 \\
\hline Maize forage produced & 0.12 & 0.27 & 0.04 & 0.44 & 0.52 & 0.57 & 0.05 & 0.16 \\
\hline Grazing land (own) & 0.26 & 0.20 & 0.33 & 0.15 & 0.12 & 0.17 & 0.22 & 0.14 \\
\hline Grazing land (rented) & 0.00 & 0.00 & 0.00 & 0.06 & 0.05 & 0.07 & 0.00 & 0.00 \\
\hline External dependence of feed & 0.62 & 0.53 & 0.63 & 0.41 & 0.36 & 0.26 & 0.73 & 0.70 \\
\hline Efficiency of external foods & 0.23 & 0.33 & 0.22 & 0.23 & 0.30 & 0.26 & 0.17 & 0.27 \\
\hline
\end{tabular}

Production and sale

\begin{tabular}{|c|c|c|c|c|c|c|c|c|c|}
\hline Milk production ( $\left.\mathrm{kg} \mathrm{cow}^{-1} \mathrm{y}^{-1}\right)$ & 3467 & 3504 & 3504 & 3285 & 3285 & 3322 & 5037 & 5147 & 5183 \\
\hline 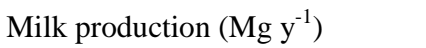 & 173.5 & 175.0 & 112.2 & 377.4 & 377.6 & 231.4 & 151.2 & 149.0 & 119.3 \\
\hline Forage maize produced $\left(\mathrm{Mg} \mathrm{y}^{-1}\right)$ & 80.5 & 80.6 & 80.5 & 338.4 & 338.5 & 332.6 & 32.5 & 28.1 & 31.8 \\
\hline Forage maize sold $\left(\mathrm{Mg} \mathrm{y}^{-1}\right)$ & 55.1 & 0.3 & 77.0 & 136.5 & 45.6 & 112.0 & 29.5 & 0.0 & 28.3 \\
\hline
\end{tabular}

\section{$\underline{\text { Objectives }}$}

$\begin{array}{lrrrrrrrrr}\text { Profit (US\$) } & 2311 & -13674 & -2787 & 57788 & 32914 & 33526 & 35884 & 13708 & 28115 \\ \text { OM balance }\left(\mathrm{kg} \mathrm{ha}^{-1} \text { ) }\right. & -435 & -334 & -473 & -665 & -560 & -670 & 509 & 1155 & 348 \\ \text { N balance }\left(\mathrm{kg} \mathrm{ha}^{-1} \text { ) }\right. & 52 & 62 & 41 & 72 & 78 & 55 & 113 & 190 & 90 \\ \text { Feeding costs (US\$) } & 40476 & 57208 & 25202 & 86752 & 113177 & 60478 & 24949 & 39640 & 18209 \\ \text { Labor balance (h) } & 7591 & 7698 & 7279 & 4852 & 5200 & 3720 & 3475 & 3443 & 2624 \\ & & & & & & \end{array}$


intensive systems their value remained negative (from -330 to $-1224 \mathrm{~kg} \mathrm{ha}^{-1}$ ). The 'integrated' functional group alternatives had reduced labor needs by 3 to 48\% (SSE and FBE, respectively), while lowering $\mathrm{N}$ balances and feed costs (Tables 4.6 and 4.7). Minimizing $\mathrm{N}$ balance led to small changes on family based farms FBE and FBM and to SSI farms of 5 and 24\%, respectively, while reducing feed costs by 9 to 52\% on FBM and SSI farms. In almost all cases, these reductions implied a decrease in the total area farmed (1-13\%, for SSI and SSM) and in herd size (15-25\%, for SSI and FBI), an increase in the area of grazing land (17-50\%, for FBI and SSM, except for FBE and FBM), and a reduction in the use of concentrates between 26 and 57\% (FBM and SSM, respectively).

\subsection{Discussion}

We explored sets of possible alternative pathways for the sustainable intensification of smallholder dairy farms in Michoacán considering the current production activities of farmers in the region as starting point. We did not explore alternative farm configurations that would imply radical changes in land use, such as moving from dairy to arable crops, fruits or other types of farming. The multiobjective optimization model FarmDESIGN was used to generate the sets of alternative farm management plans that resulted in increased physical and economic efficiencies, while reducing the negative environmental impacts associated with $\mathrm{N}$ surpluses. We use the model to identify sets of alternative solutions per farm by optimizing five objective variables that reflect three main priorities: a) profit maximization (economic functional group), b) increase soil OM (environmental functional group), and c) minimize labor needs, $\mathrm{N}$ balance and feed costs (integrated functional group), and to analyze tradeoffs and synergies between these objectives and relevant management variables. Our analysis revealed that to improve the economic performance of the dairy farms, farmers needed to diversify their outputs combining sales of milk and maize forage, and to improve herd structure with higher percentage of lactating cows. To enhance environmental performance, further intensification was required to accumulate more soil $\mathrm{OM}$, which was associated with greater stocking rate, dry matter intake, and external dependency on feedstuffs. 'Integrated' alternatives had a balance among the social, economic and environmental domains, with less labor needs (implying more time for other activities or less hired labor), lower ration costs, higher use of own resources, and reducing $\mathrm{N}$ surplus. These alternatives were predominant in extensive and intensive systems, and medium-intensive systems kept a better balance among functional groups of alternatives. Besides, semi-specialized dairy farms had broader window of opportunities of improvement than family-based systems.

We explored pathways to improve farm sustainability considering the social, economic and environmental domains, while constraining resource availability. Therefore, milk production per cow and forage yield differed from what was observed in the current case study farms. The major differences in productivity between current farms and model explorations were due to changes in 
variables related with stocking rate and cropping areas, as well as concentrate inputs to fulfill nutrient requirements of the herds. Val-Arreola et al. (2006) used compromise programing and four goal programming models to maximize the use of nutrients for milk production and income, and to minimize purchased feedstuffs, optimizing individually each objective. In their results, they found similar values for milk production in goal programming (3870 kg $\operatorname{cow}^{-1} \mathrm{y}^{-1}$ ) compared to the alternatives for FBM, SSE and SSM, while the values obtained in the alternatives of intensive systems were larger than the value found by these authors using compromise programming ( $\left.4320 \mathrm{~kg} \mathrm{cow}^{-1} \mathrm{y}^{-1}\right)$. Even though the 'economic' and 'integrated' alternatives had the greatest cost efficiency, costs per unit milk were on average higher than the US\$ $0.14 \mathrm{~kg}^{-1}$ milk obtained by Val-Arreola et al. (2006). These authors assumed year-round on-farm forage production (fresh and conserved), reducing the external dependency on feedstuffs and reducing feed costs. Considering four alternative forages with fixed forage yields and using linear programing, Val-Arreola et al. (2004) optimized land use for forage production and nutrient availability (ME and $\mathrm{CP}$ ) for the herds, assessing their economic impact in smallholder dairy farms. They found that increasing on-farm forage production by intensifying land use also increased DM, ME and CP availability, stocking rates (from 2.20 to 3.05 cows $\mathrm{ha}^{-1}$ ), milk production (by 40\%), and the efficiency of the purchased foods from US\$ $0.020 \mathrm{~kg}^{-1}$ milk to US\$ $0.003 \mathrm{~kg}^{-1}$ milk. The higher stocking rates than those found by us (Table 4.6) were associated with a higher productivity of the simulated alternative forages: alfalfa (Medicago sativa) 10 $\mathrm{t} \mathrm{ha}^{-1}$, oat (Avena sativa) $6.3 \mathrm{t} \mathrm{ha}^{-1}$, ryegrass (Lolium multiflorum Lam.) $13.0 \mathrm{t} \mathrm{ha}^{-1}$, and forage maize (Zea mays L.) $10.9 \mathrm{t} \mathrm{ha}^{-1}$.

It is often assumed that poor profitability is the major constraint to smallholder dairy in Mexico. For instance, Espinoza-Ortega et al. (2005) documented that smallholder dairy farmers in Mexico mention low milk prices and low levels of technology as their major constraints, followed by the lack of water for irrigation and high production costs. Aguilar and López (2006) indicated that dairy farmers need to maximize their return on assets and reduce their production costs. Milk production costs are explained to a large degree by the cost of producing or buying feedstuffs (Cortez-Arriola et al., 2015). In this study, our model explorations suggest that to improve their margins farmers need to diversify their production activities (including sales of forage), to search for more affordable feedstuffs, and to improve herd management (cf. Tables 4.5, 4.6 and 4.7). In other words, reducing feeding costs is only part of the solution. The 'integrated' alternatives identified through model exploration, particularly for the family-based farms, often resulted in similar or lower feeding costs than those calculated under the economic profit maximization set of alternatives. Although the selection of maximizing profit and minimizing feed costs as objective variables in the model would appear tautological, this was clearly not the case because these variables were not correlated (cf. Figure 4.2).

Profitability is influenced by other components of the systems such as the sales of maize forage and the commercialization of derived products of milk (Cortez-Arriola et al., 2015). The optimization 
procedure sometimes resulted in rations that were economically rational but not practically feasible, e.g. not including specific feedstuffs for calves and heifers, because these feedstuffs are normally expensive. In these cases, additional constraints were included to avoid imbalance rations. At the same time, the model included cheap fodders (maize stover and reed tips) that sometimes exceeded $50 \%$ of the rations. Even though the alternatives obtained during the optimization may fulfill constraints defined by nutrient requirements, it was necessary to constrain these variables to force the model to include necessary feedstuffs and to reduce the use of others. On the other hand, the definition of narrow thresholds in many of outstanding decision variables reduces the room for improvement and system innovation. This effect may especially limit the exploration of alternative solutions for the more extensively managed systems, where the model was forced to include concentrates in the ration in minimum proportions during the dry season and/or to reduce the inclusion of stover and reed tips. Considering that this stover contains maize grain and is finely ground, these were limited to about $30 \%$ of the total forage in ration to avoid depletion of DMI due to their high neutral fiber detergent content (62-75\%) (Allen, 1996). Adams (ND) considered that stover must be limited to about 20\% normal forage DM fed to milk cows because its relatively devoid of vitamins A and E.

Analyzing the evolution of minimum salary levels in Mexico, Reyes (2011) suggested that a threshold of wage of US\$6500 per year would be necessary to fulfill the basic needs of a family. Based on this threshold, the extensive systems analyzed here would not get enough economic remuneration from farming, while only the case study farms with higher sale of forage and better integration (SSM and SSI) obtained better profits. These results confirm the findings by Val-Arreola et al. (2004) for a standard small farm (5.9 ha and 13 cows) in Central Mexico. In stabled dairy systems, producing on average $8500 \mathrm{~kg}$ milk cow ${ }^{-1} \mathrm{y}^{-1}$ through on-farm forage production, Kikuhara et al. (2009) found net profits increasing 1.3 to 3.8 times the equivalent of one threshold of wage by increasing the number of cows and reducing total costs.

Reduced $\mathrm{N}$ surplus on current farms may be the result of management decisions made for other purposes, not necessarily in response to environmental concerns, which farmers consider as secondary when facing the problem of poor productivity or economic results (Espinoza-Ortega et al., 2005). In our explorations, the $\mathrm{N}$ surplus increased according to farming intensification in both dairy systems (cf. Tables 4.6 and 4.7), and same results were found by Kikuhara et al. (2009), partially explained by an increment in external foods. In the study region, inorganic fertilizers are seen as the main source of mineral nutrients for forage maize production. Application rates of $180 \mathrm{~kg} \mathrm{~N}$ ha ${ }^{-1}$ on average are recommended without a specific diagnosis or management strategy. On the other hand, manure is perceived as a waste product that costs money and labor to be removed, rather than a valuable resource that can help to sustain soil fertility, to improve the physical properties of the soil, and to retain soil moisture. Changes in manure and fertilization management for forage production may still improve the farms performance in this objective, as indicated earlier (Figueroa-Viramontes et al., 2010). 
The three most innovative aspects of the analysis presented here are (i) the exploration and comparison of solution spaces for farms differing in resource endowment and current level of intensification, (ii) the grouping of intensification options into subsets of the solution spaces that represented alternative priorities, and (iii) the assessment of farm performance relative to its own performance potential in multiple dimensions as defined by the solution space for objective variables. The solution spaces are determined by farm-specific characteristics such as available resources, technologies and management practices, and by external influences like biophysical conditions including climate, and prevailing market and policy conditions that determine prices of inputs, outputs and labor. As a consequence, the development options for the farms of different size and intensity were strikingly different (Figure 2). The solution spaces appear to evolve through time due to changes in farm-specific characteristics and external influences. Moreover, the objectives of the farmers and demands of stakeholders and society will change. Therefore, embedding explorations as presented here should be embedded in adaptive and experiential change trajectories (Groot and Rossing, 2011). However, success in the achievement of the results obtained in the exploration depends on the types, intensity and frequency of risks affecting agricultural activities. Gitz and Meybeck (2012) stated that weather shocks (sudden impacts), plant pests, animal diseases, reductions in output prices, and increases in input prices are the types of risks that impact agricultural production systems. Taking into account that dairy farmers rely highly on purchased feedstuffs for animal feeding, this dependency might represent a risk factor for the achievement of the objectives defined by means of the exploration. Furthermore, the incidence of May or June beetles (Phyllophaga spp) and fall armyworm (Spodoptera frugiperda) are in our study region potential shock risks that could reduce forage maize production and hamper the attainment of expected results. Further explorations should analyze the vulnerability and resilience of these dairy systems including potential risks in time and space.

\subsection{Conclusions}

The exploration of alternatives of sustainability intensification generated potential solutions that may improve current dairy farm performance based on a simple re-arrangement of existing farm resources. These alternatives were oriented to fulfill specific objectives established for the exploration based on the decision variables established. The window of opportunities of improvement and diversity of alternatives were strongly defined by the original farm configuration. Dairy farms with more limited resources and/or more deficient farm management had a narrow space to enhance their performance. These insights on the alternatives intensification pathways per farm type generated during the exploration of alternatives might help decision makers to establish policies for this sector, and might inform stakeholders and farmers to define priorities and to identify solutions and technical interventions for specific set of farm types. The farm-scale model explorations suggest that there is 
room to improve overall performance of current farms, including aspects such as overall farm profitability and soil organic matter accumulation. Improvements in these aspects of the systems may warrant the longevity of the local dairy sector while also preserving the production basis via enhanced resource management and allocation. However, additional innovations may be needed to further manage the vulnerability and resilience of these systems in face of increased global price fluctuations in inputs and potential climatic risks associated with global warming.

\subsection{References}

Adams, R.S., ND. Corn stover as feed for cattle. Penn State, College of Agricultural Science. http://extension.psu.edu/prepare/emergencyready/drought/dairylivestock/cornstover (Accessed August, 2012).

Aguilar, A., and López, M., 2006. Cómo lograr que la ganadería lechera mexicana sea competitiva a nivel internacional. Revista Mexicana de Agronegocios X (18): 1 - 14 .

Allen, M.S., 1996. Physical constraints on voluntary intake of forage by ruminants.J. Anim. Sci. 74: $3063-3075$.

Améndola, R.D., 2008. Balance de la alimentación en la producción intensiva de leche en pastoreo. http://www.edicionespecuarias.com.mx/pdf/complemento_editorial/nutriciero/2008/30/poh CEBALANCE\%20ALIMENTACI\%D3N.pdf (Accessed February, 2011).

Armstrong, D.P., Knee, J.E., Doyle, P.T., Protchard, K.E., and Gyles, N.A., 2000. Water-use efficiency on irrigated dairy farms in northern Victoria and southern New South Wales. Australian Journal of Experimental Agricutlure 40: 643 - 653

Castelán-Ortega, O.A., Fawcett, R.H., Arriaga J., C., and Herrero, M., 2003. A decision support system for smallholder campesino maize-cattle production systems of the Toluca Valley in central Mexico. Part II - Emulating the farming system. Agricultural Systems. 75: 23 - 46.

CEFP (Centro de Estudios de las Finanzas Públicas), 2009. Evolución de las tasas de interés activas, pasivas y su entorno internacional. Cámara de Diputados LX Legislatura. México, D.F. 12 p.

Cleveland, C.C., Towsend, A.R., Schimel, D.S., Fisher, H., Howarth, R.W., Hedin, L.O., Perakis, S.S., Latty, E.F., Von Fisher, J.C., Elseroad, A., and Wasson, M.F., 1999. Global pattern of terrestrial biological nitrogen $\left(\mathrm{N}_{2}\right)$ fixation in natural ecosystems. Global Biogeochemical Cycles 13 (2): $623-645$.

Cortez-Arriola, J., Groot, J.C.J., Améndola M., R.D., Scholberg, J.M.S., Mariscal A., D.V, Tittonell, P., and Rossing, W.A.H., 2014. Resource use efficiency and productivity gaps of smallholder dairy farming in North-west Michoacán, Mexico. Agricultural Systems 126: 15 $-24 \mathrm{p}$. 
Cortez-Arriola, J., Rossing, W.A.H., Améndola M., R.D., Scholberg, J.M.S., Groot, J.C.J., and Tittonell, P., 2015. Leverages for on-farm innovation from farm typologies? An illustration for family-based dairy farms in north-west Michoacán, Mexico. Agricultural Systems 135: $66-76$.

DeLorenzo, M.A., and Thomas, C.V., 1996. Daily records and models for economic and financial planning. J. Dairy Sci. 79: 337 - 345.

Espinoza-Ortega, A., Álvarez-Macías, A., Del Valle, M. del C., and Chauvete, M., 2005. Small-holder (campesino) milk production systems in the highlands of Mexico. Técnica Pecuaria México 43 (1): $39-56$.

Figueroa-Viramontes, U., Cueto-Wong, J.A., Delgado, J.A., Núñez-Hernández, G., Reta-Sánchez, D.G., Qiroga-Garza, H.M., Faz-Contreras, R., and Márquez-Rojas, J.L., 2010. Estiércol de bovino lechero sobre el rendimiento y recuperación aparente de nitrógeno en maíz forrajero. Terra Latinoamericana 28(4): 361 - 369.

FAO, 2006. World agriculture: towards 2030/2050. Interim report, Global Perspective Studies Unit. Rome, Italy: Food and Agriculture Organization of the United Nations. 71 pp.

FAO, 2012. Statistical database. http://faostat.fao.org/site/291/default.aspx (Accessed October, 2012).

Galloway, J.N., Townsend, A.R., Erisman, J.W., Bekunda, M., Cai, Z., Freney, J.R., Martinelli, L.A., Seitzinger, S.P., and Sutton, M.A., 2008. Transformation of the nitrogen cycle: recent trends, questions, and potential solutions. Science 320: 889 - 892.

Gitz, V., and Meybeck, A., 2012. Risks, vulnerabilities and resilience in a context of climate change. in: FAO/OECD Workshop: Building resilience for adaptation to climate change in the $\begin{array}{lllll}\text { agricultural } & \text { sector, } & \text { Rome, } & \text { Italy, } & \text { 23-24 }\end{array}$ http://typo3.fao.org/fileadmin/templates/agphome/documents/faooecd/gitz.pdf (Accessed January, 2013).

Gourley, C.J.P., Aarons, S.R., and Powell, J.M., 2012. Nitrogen use efficiency and manure management practices in constrasting dairy production systems. Agriculture, Ecosystems and Environment 147: 73 - 81.

Groot, J.C.J., Jellema, A., and Rossing, W.A.H., 2010. Designing a hedgerow network in a multifunctional agricultural landscape: balancing trade-offs among ecological quality, landscape character and implementation costs. European Journal of Agronomy 32: 112 119.

Groot, J.C.J., and Rossing, W.A.H., 2011. Model-aided learning for adaptive management of natural resources: an evolutionary design perspective. Methods in Ecology and Evolution 2, 643 650.

Groot, J.C.J., Oomen, G.J.M., Rossing, and W.A.H., 2012. Multi-objective optimization and design of farming systems. Agricultural Systems 110: 63 - 77. 
Härdle, W., and Hlávka, Z., 2007. Multivariate statistics: Exercises and solutions, first ed. Springer, Berlin, Germany.

Hazell, P., and Wood, S., 2008. Drivers of change in global agriculture. Phil. Trans. R. Soc. B 363: $495-515$.

Henry, G.M., DeLorenzo, M.A., Beede, D.K., van Horn, H.H., Moss, C.B., and Boggess, W.G. 1995. Determining optimal nutrient management strategies for dairy farms. J. Dairy Sci. 78: 693 703.

Hudson, N.W., 1993. Field measurement of soil erosion and runoff. Food and Agriculture Organization of the United Nations (FAO). Rome, Italy. http://www.fao.org/docrep/T0848E/t0848e-07.htm\#P734_33062 (Accessed March, 2009).

Hutching, T.R., and Nordblom, T.L., 2011. A financial analysis of the effect of the mix of crop and sheep nterprises on the risk profile of dryland farms in south-eastern Australia. AFBM Journal 8 (1): 19 - 42.

INEGI, 2010. Principales resultados del censo de población y vivienda 2010. Instituto Nacional de Estadística y Geografía. Aguascalientes, México. 122 p.

Kikuhara, K., Kumagai, H., and Hirooka, H., 2009. Development and evaluation of a simulation model for dairy cattle production systems integrated with forage crop production. AsianAust. J. Anim. Sci. 22 (1): 57 - 71.

Lara-Covarrubias, D., Mora-Flores, J.S., Martínez-Damián, M.A., García-Delgado, G., OmañaSilvestre, J.M., and Gallegos-Sánchez, J., 2003. Competitividad y ventajas comparativas de los sistemas de producción de leche en el Estado de Jalisco, México. Agrociencia 37: 85 94.

Mandryk, M., Reidsma, P., Kanellopoulos, A., Groot, J.C.J., and Van Ittersum, M., 2014. The role of farmer's objectives in current farm practices and adaptation preferences. Regional Environmental Change 14 (Issue 4): 1463 - 1478.

Naylor, R., Steinfeld, H., Falcon, W., Galloway, J., Smil, V., Bradford, E., Alder, J., and Mooney, H., 2005. Losing the links between livestock and land. Science 310: 1621 - 1622.

Nordström, E-M., Romero, C., Eriksson, L.O., and Öhman, K., 2009. Aggregation of preferences in participatory forest planning with multiple criteria: an application to the urban forest in Lycksele, Sweden. An. J. For. Res. 39: 1979 - 1992.

NRC, 1989. Nutrient requirements of dairy cattle, sixth revised ed. National Academy Press, Washington, D. C.

NRC, 2001. Nutrient requirements of dairy cattle, seventh revised ed. National Academy Press, Washington, D. C. 
Pennock, D., Yates, T., and Braidek, J., 2006. Soil sampling designs, in: Carter, M. R., Gregorich, E. G. (Eds.), Soil sampling and methods of analysis. M. R., second ed. Canadian Society of Soil Science. Florida, USA.

Reyes, M.S., 2011. Análisis político: Los salarios en México. Fundación Friedrich Ebert Stiftung. 26 p.

SAGARPA, 2010. Situación actual y perspectiva de la producción de leche de bovino en México 2010. Claridades $\quad$ Agropecuarias 34-43. http://www.infoaserca.gob.mx/claridades/revista/207/ca207.pdf (Accessed May, 2011).

SE (Secretaría de Economía), 2012. Análisis del sector lácteo en México. Secretaría de Economía. In: http://www.economia.gob.mx/files/comunidad_negocios/industria_comercio/informacionSe ctorial/analisis_sector_lacteo.pdf (Accessed November, 2012).

Secretaría de Gobierno, 2010. H. Ayuntamiento Constitucional de Marcos Castellanos: Plan de Desarrollo Municipal. Periódico Oficial del Gobierno Constitucional del Estado de Michoacán de Ocampo, Tomo CXLIX, Núm. 46. 16 p.

SEMARNAT, 2003. Informe de la situación del medio ambiente en México 2002. Compendio de Estadísticas Ambientales: 2. Vegetación y uso del suelo. Secretaría de Medio Ambiente y Recursos Naturales. D.F., Méx.. 31 - 83.

Smaling, E.M.A., and Fresco, L.O., 1993. A decision-support model for monitoring nutrient balances under agricultural land use (NUTMON). Geoderma 60: 235 - 256.

Sterk, B., Van Ittersum, M.K., Leeuwis, C., and Wijnands, F.G., 2007. Prototyping and farm system modelling - partners on the road towards more sustainable farm systems?. Europ. J. Agronomy 26 (4): 401 - 409.

Tittonell, P., Van Wijk, M.T., Rufino, M.C., Vrugt, J.A., and Giller, K.E., 2007. Analysing trade-offs in resource and labour allocation by smallholder farmers using inverse modelling techniques: a case-study from Kakamega district, western Kenya. Agricultural Systems 95: $76-95$.

Thornton, P.K., and Herrero, M., 2001. Integrated crop-livestock simulation models for scenario analysis and impact assessment. Agricultural Systems 70: $581-602$.

Thornton, P.K., 2010. Livestock production: recent trends, future prospect. Phil. Trans. R. Soc. B 365: $2853-2867$.

Val-Arreola, D., Kebreab, E., Mills, J.A.N., Wiggins, S.L., and France, J., 2004. Forage production and nutrient availability in small-scale dairy systems in central Mexico using linear programming and partial budgeting. Nutrient Cycling in Agroecosystems 69: 191 - 201.

Val-Arreola, D., Kebreab, E., and France, J., 2006. Modeling small-scale dairy farms in central Mexico using multi-criteria programming. J. Dairy Sci. 89: 1662 - 1672. 
Van Keulen, H., and Breman, H., 1990. Agricultural development in the West African Sheilan region: a cure against land hunger?. Agriculture, Ecosystems and Environment 32: 177 - 197.

Vishwanath, R., 2003. Artificial insemination: the state of the art. Theriogenology 59: $571-584$.

Wadsworth, J., 1997. Análisis de Sistemas de Producción Animal - Tomo 2: las Herramientas Básicas. Food and Agriculture Organization of the United Nations (FAO Producción y Sanidad Animal 140/2). http://www.fao.org/docrep/w7452s/w7452s00.htm\#Contents (Accessed February, 2010).

Westphal, P.J., Lanyon, L.E., and Partenheiner, E.J., 1989. Plant nutrient management strategy implications for optimal herd size and performance of a simulated dairy farm. Agricultural Systems 31: $381-394$.

Whitbread, A.M., Robertson, M.J., Carberry, P.S., and Dimes, J.P., 2010. How farming systems simulation can aid development of more sustainable smallholder farming systems in southern Africa. Euro. J. Agronomy 32: 51 - 58. 


\section{Chapter 5: Capturing agro- ecosystem vulnerability and resilience}

Jeroen C.J. Groot, José Cortez-Arriola, Walter A.H. Rossing, Ricardo D. Améndola Massiotti, Johannes M.S. Scholberg, Pablo Tittonell. 


\begin{abstract}
Vulnerability and resilience are two crucial attributes of social-ecological systems that are used to analyze the response to disturbances. Quantitative assessments of these attributes contributing to reduce subjectivity and abstractness are scarce. We present a generic quantitative approach to analyze and assess the vulnerability, buffer capacity and adaptive capacity of agro-ecosystems. We relate these attributes to solution spaces that represent the possible changes in terms of selected performance indicators as affected by adjustments in components, processes and management of the systems. We expressed the vulnerability of the system as the Euclidian distance of performance indicators between original and disturbed systems. The buffer capacity was derived from the size of the solution space that could be obtained after reconfiguration of farm components (crops, animals, fertilizers, etc.) that were present on the original farm, whereas the assessment of adaptive capacity was derived in a similar way but after allowing innovation by introducing new components to the farm. We applied these concepts to a small family-based (FB) and a larger semi-specialized (SS) dairy farm in Northwest Michoacán, Mexico. After a disturbance resulting in a yield decline the economic and one of the environmental performance indicators (profitability and soil organic matter) were negatively affected on both farms. The scope for recovery was larger for the SS farm than for the FB farm, as reflected in higher buffer and adaptive capacity. Improvements in profitability and organic matter balance would require considerable changes in the farm configurations, and thus flexibility in farm management. For a farmer with the managerial ability to make the required changes to move through the solution space the whole-system resilience would be large. The approach we present here offers a quantitative assessment of vulnerability and resilience concepts, based on a combined assessment of the social and ecological dimensions of agro-ecosystems.
\end{abstract}

Key Words: Multi-objective optimization; buffer capacity; adaptive capacity; solution space.

Submitted. 


\subsection{Introduction}

Hundreds of millions of farmers worldwide are confronted with increasing uncertainty due to gradual changes and sudden fluctuations in demography, climate, market prices for inputs and products, policies and geo-political conflicts (Meinke et al., 2009; Gornall et al., 2010; Herrero et al., 2010; Suweis et al., 2015). In order to maintain their livelihoods, and to secure the supply of food for a growing global population and the provision of other ecosystem services from rural landscapes, these agroecosystem managers have to minimize their vulnerability and should be able and willing to adapt to the changing circumstances.

Resilience and vulnerability are two attributes of socio-ecological systems that are used to analyze the response of socio-ecological systems to perturbation at local, regional or global level. Vulnerability represents the magnitude of change of a system after a disturbance without a change in its function (Miller et al., 2010), whereas resilience focuses on the capacity of the system to absorb disturbances and reorganize while undergoing change so as to still retain the same function and structure (Walker et al., 2009; Miller et al., 2010; Gitz and Meybeck, 2012). These concepts have been useful in providing insight into the complexities of natural resource management in social-ecological systems. Even though vulnerability and resilience are two different approaches, both apply to the analysis of whole systems in multiple spatial and temporal scales, in the context of system disturbances, and capture the extent to which systems are resistant to change and able to adapt (Miller et al., 2010; Gitz and Meybeck, 2012). Their most salient application has been in the metaphoric sense, to illustrate the dynamics of systems development cycles (adaptive cycles), to show interrelations among scales within coupled social-ecological systems, and to indicate the necessity of preparedness for disturbances and adaptation at all hierarchical levels (Gunderson and Holling, 2001; Brand and Jax, 2007; Walker et al., 2010).

Disturbances differ in the intensity, duration and frequency of the impact. Shocks denote sudden perturbations for a short period of time, whereas stresses affect a system uninterruptedly for longer time span (years) and with certain level of predictability (Darnhofer et al., 2010). Both types of disturbance can have their impact directly on a system only on one of its subsystems or components and indirectly on more than one of its subsystems, and it can be at local, regional or global level (Darnhofer et al., 2010; Gitz and Meybeck, 2012). In agricultural systems, Gitz and Meybeck (2012) classified the type of disturbances in economic and access to markets (input price increase, output price decrease, inputs availability, and uncertainty on land tenure); climatic (weather shocks like extreme temperatures and precipitation rates), and management practices (plant pests, animal diseases, overharvesting, and overgrazing). Such disturbances to farms negatively impact on system productivity and profitability. In dairy farm systems, social, environmental and economic domains are strongly linked to the animal and crop subsystems, where on-farm grassland or forage production is 
used as an alternative to reduce the external dependency of feeding and feeding costs, to recycle nutrients, and as source of income. Due to the complex interrelations among subsystems and the damage that these systems might suffer, it is relevant to distinguish the disturbance and quantify the magnitude of the impacts, and the level of effect in the social, economic and environmental system domains.

Farmers might implement different management strategies to maintain the structure and function in their systems after disturbances. However, the response of the system depends on the magnitude of the damage, the buffer capacity of the systems against risks, its self-organization, and the efficiency of the strategies implemented by the system manager (Carpenter et al., 2001; Darnhofer et al., 2010; Ifejika, 2013). Nowadays, different theoretical mental models and practical approaches are available to understand and assess vulnerability and resilience in agricultural systems at different space and time levels (Darnhofer et al., 2010; Eakin et al., 2012; Gitz and Meybeck, 2012; Ifejika, 2013; Tittonell, 2014). Nonetheless, there still remains the challenge of quantitatively analyze vulnerability and resilience at farm and systems level, aiming at more resistant and resilient states (Darnhofer et al., 2010; Miller et al., 2010). Luers et al. (2003, 2005) and Darnhofer et al. (2008) also pointed out the need for approaches that use numerical analysis in the assessment of vulnerability and resilience.

More quantitative approaches that make the concept of resilience and vulnerability operational include dynamic systems analysis and the quantitative techniques which support adaptive management. In dynamic systems analysis, ecological systems have been modeled in terms of differential equations that simulate the changes in slow and fast state variables. This method has been effective in demonstrating that ecosystems have multiple stable states and that they can collapse due to inappropriate too intensive management (Scheffer et al., 2001; Carpenter et al., 2001; Beisner et al., 2003; Luers et al., 2003; Suding et al., 2004; Folke et al., 2004). After such a regime shift to a degraded state, recovery to a desirable state might be difficult or impossible. The occurrence of overuse of systems or of their components has been attributed to the lack of feedback and correction mechanisms, in the human dominated world in particular in the socio-institutional and economic parts of systems (Scheffer et al., 2000; Anderies et al., 2004).

Here we apply resilience and vulnerability in an illustration using quantitative farming systems models. Both dynamic and static quantitative representations of farming systems have been put forward in the literature. For instance, Groot et al. (2003) and Shah et al. (2013) developed a dynamic model of a dairy farm that is characterized by three state variables describing organic nitrogen and carbon and inorganic nitrogen pools, respectively, and grassland and cattle management that intervenes in the rates of change of the states. In contrast to this relatively simple, analysis-oriented model, Power et al. (2011) present a dynamic model of an arable farm with a large number of state variables describing soil-crop-atmosphere relations on different fields and their cross-field interactions, aiming at representativeness of reality. Static farming system models represent key 
elements of farming systems as balances of economic, social and environmental indicators, aggregating changes over time periods of typically a year (see review by Janssen and van Ittersum, 2007). Static farm models are generally far more tractable than dynamic farm models, but inherently lack dynamic feedbacks. Nevertheless, they may be applied in a semi-dynamic manner where the researcher re-initializes the model to mimic a disturbance. To our knowledge, such application is novel and may open up a new line of farming systems research.

The aim of this study was to present a quantitative approach to analyze and assess vulnerability and resilience in agricultural systems. The approach is illustrated through the analysis of these properties of Family-based (FB) and Semi-specialized (SS) dairy farms in Marcos Castellanos, Michoacán, Mexico, that undergo a shock disturbance in the form of a reduction in forage maize production. Alternative management options to strengthen system resilience (hereafter called "innovation”) are evaluated using a multi-objective farm-scale optimization model. This approach represents a way to operationalize and to reduce subjectivity and abstractness of the concepts of vulnerability and resilience.

\subsection{Conceptual approach}

The evolving nature of complex adaptive systems has been conceptualized as a continuous adaptive cycle (Holling, 1986) of phases of growth, accumulation, restructuring, and renewal. The degree to which social-ecological systems can perpetuate these cycles depends on three general system properties (Holling, 2001). The first property is the 'potential' of a system, which is determined by the availability of options for future development that allow a system to continue functioning at a desired level for a predefined set of state variables after a disturbance. The other properties are the 'controllability' and 'resilience' of the system, which reflect the rigidity or flexibility for adaptation and change and determine the degree to which a system is affected by and can recover from a disturbance (Holling, 2001).

The 'potential' of the system can be associated with two other ecosystem properties, buffer capacity and adaptive capacity (Carpenter et al., 2001; Milestad and Darnhofer, 2003). We define buffer capacity as the ability of the system to continue performing at a similar performance level after a disturbance without structural changes in the number or diversity of components and processes in the system. In systems that are characterized by high diversity the probability of the presence of redundant components and links is high, which supports the buffer capacity (Walker et al., 2006) because links and flows can be redirected to support crucial system processes without compromising other vital functions. Adaptive capacity is the ability to reconfigure and recover performance after new components have been introduced into the system.

Agroecosystems are coupled human-environment systems wherein the farmer, who participates in a 
larger socio-institutional network, manages part of the ecosystem with the aim to eventually harvest crop and/or animal products either for self-consumption or the market. The ecological part of the system can be strongly dependent on biological processes such as nutrient cycling through animal manures and crop residues and pest suppression by natural enemies of crop pests, or more dependent on external inputs that can be imported from communal resources (e.g., food, feed, bedding for animals) or purchased on markets (e.g., seeds, fertilizers, pesticides, feeds). The concept of the 'potential' of the system is reflected in the ways the farmer can reconfigure crops, animals, resources and management practices on his farm to reach a desired productive, environmental and social outcome given the biophysical, socio-economic and political environment in which he operates. A disturbance can be a pest or drought or product price decline that can negatively affect the farming system performance. The farmer can respond by reconfiguring the farm with changes in for instance crop areas, animal numbers, amounts of inputs, selected market channels or management practices to compensate for the effect of the disturbance. The available options for adjustment of the system with existing components and resources can be considered as the 'buffer capacity'. When the farmer decides to introduce new crops, animals, inputs or practices the required adjustment and reconfiguration (both in the ecological system and in farm management) is expected to be considerably larger and is reflected in the 'adaptive capacity'. This illustration of the concepts for an agroecosystem demonstrates that, besides the ecological (self-) organization, the farmer, his flexibility and skills, and his cognitive and managerial capacities will determine the chosen strategy of adaptation and the final effectiveness of reconfiguration, and thus agroecosystem resilience.

All possible combinations of values of state variables constitute the 'window of opportunities' or 'solution space' for a particular system (Groot and Rossing, 2011). The potential of a system (P), resulting from buffer and adaptive capacity, can be derived from the size of the solution space, which defines the options for adjustment of the system. The solution space is delimited by the Pareto frontier (or Pareto surface when more than two performance criteria are included in the analysis), and for assessment of resilience we consider only options that perform at least as good as the existing system. The Pareto frontier can be established using multi-objective optimization, and the area (in 2 dimensions), volume (3 dimensions) or hyper volume ( $>3$ dimensions) of the solution space can be calculated (Auger et al., 2012), for instance relative to a given reference point that represents the existing situation. This is demonstrated in Figure 5.1, wherein only the portion of the solution space with improvements in two system states (productivity and environmental quality in this case) relative to the existing situation after a disturbance is depicted. The buffer capacity (area B in Figure 5.1a) is estimated as the solution area corresponding to the reconfiguration of links and flows among the components that are already in the system. The adaptation capacity (area A in Figure 5.1a) is estimated as the expansion of the solution area when new components are introduced in the system. The potential $(\mathrm{P})$ is estimated as the sum of areas $\mathrm{A}$ and $\mathrm{B}$. 


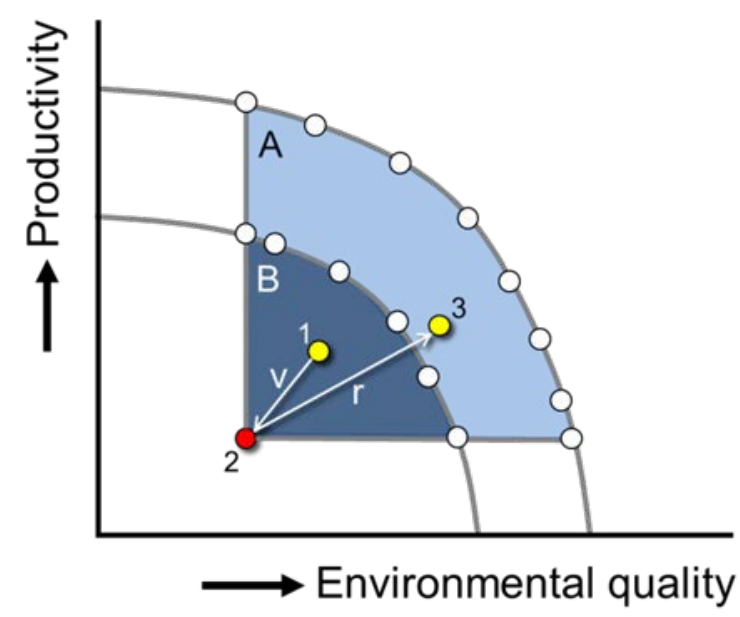

(a)

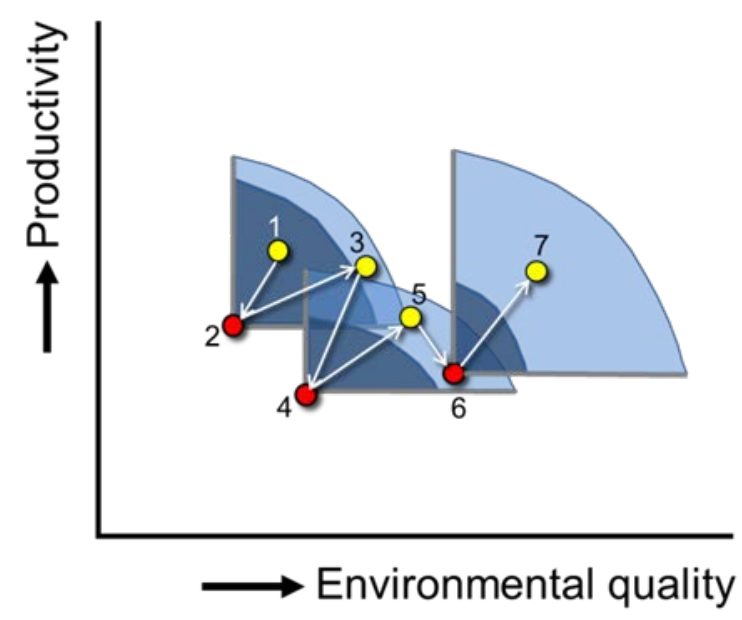

(b)

Figure 5.1. Portions of solution spaces with future options that perform better for both state variables productivity and environmental quality, relative to disturbed states denoted by red symbols. (a) After a disturbance the system states change following the arrow from point 1 to point 2 (vulnerability $\mathrm{v}$ is the distance between points 1 and 2), and move to a more desirable state such as point 3 (resilience $r$ is the distance between points 2 and 3). Area A represents the adaptive capacity and B the buffer capacity of the system after the disturbance. Potential P is calculated are the sum of areas A and B. White symbols denote alternatives for the current system. (b) The potential of a system at consecutive moments in time, with changing attained states (points 1, 3, 5 and 7) and after disturbances (points 2, 4 and 6).

Disturbances result in a deterioration of the performance of at least one of the state variables. This is visualized by the change in system state from point 1 to point 2 in Figure 5.1a. The distance (here measured in unit of ordinate per unit abscissa) between these points represents the vulnerability (v) of the system to the disturbance. $\mathrm{P}$ represents the whole range of future development options that all differ in their degree of change that is needed to move from the disturbed state to a new, more desirable configuration. Which option will actually be realized (for instance point 3 in Figure 5.1a) depends on the ability to rebalance interactions and flows within the system, which have to be rebalanced through (self-) organization. This requires flexibility, learning and experimentation. It can be expected that in many cases larger improvements in performance of state variables relative to the initial situation will also require larger adjustments in system configuration and organization. The distance between points 2 and 3 is the recovery ( $r$ ) of the system. We propose to estimate the resilience as $\mathrm{R}=\mathrm{r} / \mathrm{v}$, denoting the ability of a system to recover after a shock.

The size and shape of the solution space will change continuously since the system and its environment are subject to adjustments, for instance in bio-physical environment, or due to technological and socio-institutional innovations (Groot and Rossing, 2011). For instance, declines in soil fertility resulting from erosion or invasion of the system by a new pest will reduce crop yields and 
productive farm performance; increased water infiltration and nutrient leaching due to enhanced precipitation associated with climatic change will affect the environmental impact of farming activities; changes in policy regimes and introduction of new taxation or subsidy schemes will alter the economic revenues from the agro-ecosystem. As a consequence, the vulnerability and resilience of the system should also be considered as dynamic properties. This is illustrated in Figure 5.1b, which shows a sequence of disturbed and recovered system states.

\subsection{Illustration: Vulnerability and resilience of dairy farms}

\subsubsection{Regional characterization}

The municipality of Marcos Castellanos is located North-west of Michoacán State $\left(19^{\circ}\right.$ northern latitude and $103^{\circ}$ western longitude) at altitudes between 1,500 and 2,400 masl. The area of this municipality is 23,285 ha, and $86 \%$ of it is classified as grazing land (mainly constituted by native species of grasses) and $12 \%$ is cropland (mostly for maize forage production) (Secretaría de Gobierno, 2010). The climate is classified as temperate with one main rainy season between June and October; precipitation and temperature averages are $798 \mathrm{~mm}$ and $18.9^{\circ} \mathrm{C}$. Due to the prolonged dry season (from November to May) and the prohibition to exploit the aquifer for agricultural activities since 1987, forage production in the grazing lands and crop lands is negligible in this period.

\subsubsection{Dairy farm characterization}

In the study region, small family-based and somewhat larger and more intensive semi-specialized dairy farms can be found (Cortez-Arriola et al., 2014; Cortez-Arriola et al., 2015). For this study, two medium-intensive dairy farms with cattle density between 0.8 to 1.2 livestock units (LU) per ha representing family-based (FB) and semi-specialized (SS) enterprises were selected as pilot farms. The dairy farms in the study region are characterized by using Holstein Frisian cows and crosses of this breed with Zebu and Brown Swiss. Cows are milked twice daily, and the milk produced is sold as raw milk directly to middlemen or local dairy industries. During the milking time, the lactating cows receive concentrate to complement the grazed and conserved forage; the supplied amount of concentrate is large and varies between 4.5 and $8.4 \mathrm{~kg}$ dry matter $\mathrm{LU}^{-1}$ day $^{-1}$ during the rainy season, and between 5.7 and $7.6 \mathrm{~kg} \mathrm{DM} \mathrm{LU}^{-1} \mathrm{~d}^{-1}$ during dry season. Maize forage is mainly produced in the farms exclusively for cattle feeding, and it is conserved as silage or stover (whole plant hay) to compensate for the lack of forage from the grazing lands during the dry season. However, it is not exclusive for this season neither the only source of conserved forage in the region, since hay of alfalfa, annual ryegrass and chickpea represent alternative sources of forage available in the regional market. For the maize crop management, herbicides for weed control, insecticide for Phyllophaga spp. pest prevention, and fertilizers with nitrogen and phosphorus are commonly applied in cropland without 
manuring. Basic information describing farms size, land use types, herd structure, productivity, diet composition, and labor of the selected farms is included in the supplementary material, Tables 5.S1 (FB) and 5.S2 (SS).

\subsubsection{Vulnerability and resilience assessment}

The FarmDESIGN model, which evaluates farm configurations and their performance on an annual basis, was used to quantify social, economic, and environmental performance indicators of the farms, and to explore solution spaces of these farms using a Pareto-based multi-objective optimization algorithm. During the optimization, the model generates alternatives of agricultural production systems by adjusting farm components (crops and animals) and inputs (for crop and animal production). These farm components are the decision variables, the values of which are drawn from predefined intervals. Subsequently, the model evaluates the generated alternatives with selected performance indicators (objectives that are either minimized or maximized) and it selects the best solutions for a next iteration of improvement on the basis of the Pareto principle (Groot et al., 2012). In this illustration, the selected objectives were: maximizing farm profitability, maximizing the soil organic matter (OM) balance (as indicator of soil quality improvement), and minimizing the farm nitrogen $(\mathrm{N})$ balance (as indicator of nutrient losses to the environment). More detailed information of the operational procedure of the model is included in the supplementary material, Box 5.S1.

Conserved maize forage is one of the main sources of fodder during the dry season in the study region (Cortez et al., 2014; Cortez et al., 2015). Therefore, vulnerability was estimated considering the impact of a reduction in forage maize production, as a shock disturbance on the selected farms. After the analysis of the farm performance for the period 2009-2010, considering the decision variables and constraints listed in Tables 5.S1 and 5.S2, the forage maize yield was replaced by the forage maize yield of the period 2008-2009 (Table 5.S3). In both farms, the forage maize yield was lower in 20082009 due to low rates of seeding and fertilizing and the incidence of fall armyworm (Spodoptera frugiperda). The vulnerability of the farms to this change was assessed by comparing the values of the objectives between the original farm and the situation with reduced forage maize production.

The newly introduced practices of forage barley cropping and manure application were evaluated as strategies of farm management to resist and to adapt the farms to reductions in forage maize yield, and to estimate farm resilience and farm potential (from buffer and adaptive capacity). In the model, forage barley was considered to be grown following silage maize, benefitting from the last rains of the season and the residual soil moisture. This is not a common cropping practice in the study region, and information on forage barley production and use was obtained from Lizárraga et al. (1980). In the model manure was available due to collection in the stables and in the yards during the dry period.

The buffer capacity (B) and the adaptive capacity (A) areas of the farms (cf. Figure 5.1a) were obtained by exploring alternative farm configurations based on the ranges in decision variables as 
shown in Table 5.S4, using as starting point the perturbed farm that suffered forage maize yield loss due to $S$. frugiperda. To assess the extent of managerial changes compared to the starting point, we calculated a 'relative change index' as the sum of squared normalized changes for each of the decision variables (Equation 5.1). Larger values for this relative change index indicate larger changes in management.

$C=\sum_{p=1}^{n}\left(\frac{X_{p, q}-X_{p, \min }}{X_{p, \max }-X_{p, \min }}\right)^{2}$

Where:

$\mathrm{C}=$ relative change index.

$\mathrm{n}=$ number of decision variables.

$\mathrm{x}_{\mathrm{p}, \mathrm{q}}=$ value of decision variable $\mathrm{p}$ for alternative $\mathrm{q}$ from the set of solutions.

$\mathrm{x}_{\mathrm{p}, \min }=$ minimum value of decision variable $\mathrm{p}$.

$\mathrm{x}_{\mathrm{p}, \max }=$ maximum value of decision variable $\mathrm{p}$.

\subsection{Results}

\subsubsection{Vulnerability}

Perturbation of the FB and the SS farms by assuming maize forage production to be as low as in 200809 resulted in a decline in profitability and soil OM balance of both farms compared to 2009-10 baseline. The $\mathrm{N}$ balance was not affected (Figure 5.2; Table 5.1). In terms of profitability, SS was more vulnerable to the reduction in forage maize production than FB, because SS derived its income from sales of milk and forage maize, while FB depended on sales of milk only (Figure 5.2; Table 5.2). Since forage maize production contributes to the OM balance through residues that remain in the field (roots and stems) and through forage losses during harvesting and feeding, the maize yield reduction implied slight declines in the OM balance on both farms (Figure 5.2; Table 5.2).

\subsubsection{Buffer capacity and adaptive capacity}

Reconfiguration of the farms with the existing farm components (crops, animals, fertilizers, feeds, etc.) provided options to improve the three objectives, but the SS farm than for the FB farm. Thus, the buffer capacity as indicated by the range of Pareto optimal options in Figure 5.2 was much larger for SS than for FB. Introducing the new practice of growing barley after maize and assuming improved manure management offered even larger improvements in the three objectives, and demonstrated the adaptive capacity of the farms. Also here the solution space for SS exceeded that for FB (Figure 5.2). 


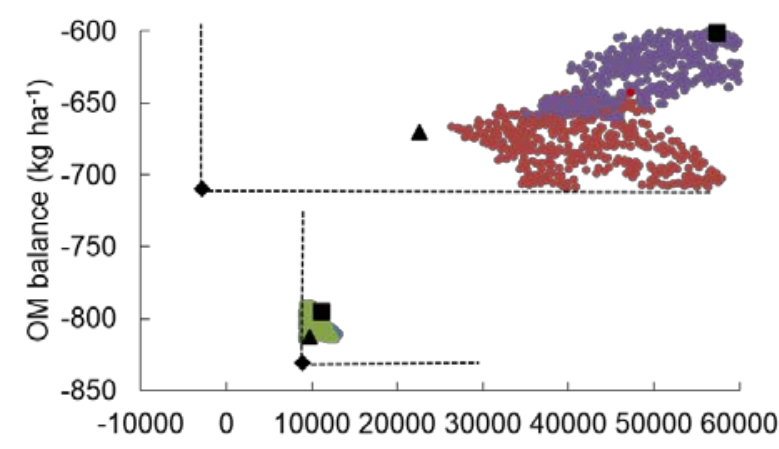

- FBM_Maize forage reduc

- SSM_Maize forage reduc

- FBM_Barley+Manuring

- SSM_Barley+Manuring

$\Delta$ Current performance

- Maize forage reduc

-Barley forage+Manuring
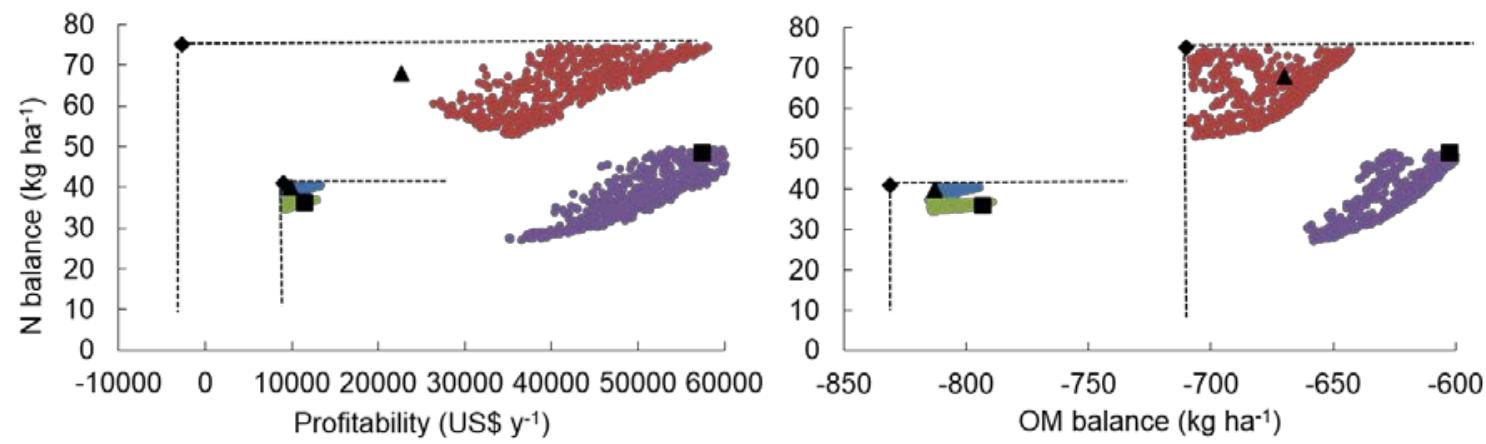

Figure 5.2. Original dairy farm performance $(\boldsymbol{\Delta})$, and the response to the perturbation of forage maize yield reduction ( $\bullet$ ) for family-based (FB) and semi-specialized (SS) medium intensive (M) dairy farms in Marcos Castellanos based on profitability, and $\mathrm{OM}$ and $\mathrm{N}$ balances as objective variables. The blue (FBM) and red (SSM) symbols represent buffer capacity, and the green (FBM) and purple (SSM) symbols display adaptive capacity (including the new technologies of forage barley and manure application). For illustration of resilience, one option per farm was selected ( $\mathbf{\square})$.

\subsubsection{Required changes in farm management}

The relation between the attainable improvement in the objectives and the required adjustments in farm management is illustrated for farm SS in Figure 5.3. To enable comparability among objectives, the objective values were normalized. As shown by the color-coded values of the relative change index (calculated as the sum of squared normalized change in the decision variables, equation 1), the largest adjustments in management were required to increase the organic matter balance (Figure 5.3).

\subsubsection{Resilience}

To illustrate the quantification of resilience R (Table 5.2), one farm configuration was selected for each of the two farms from the explorations of adaptive capacity (Figure 5.2). Although the absolute improvements in objective variables that could be attained (denoted as recovery r) were considerably larger for farm SS than for FB, the resilience R (calculated as the improvement relative to the absolute value of the impact of the disturbance, i.e. vulnerability v) was similar for both farms. Only for the OM balance, resilience R was larger for SS (2.7) than for FB (2.0). To reach the improvements in SS, larger adjustments in the farm configuration were needed with a relative change index of 2.9 for SS 
and 1.5 for FB. The actual resilience will depend on the ability of the farm managers to make the required adjustments to improve farm performance to reach the projected recovery.
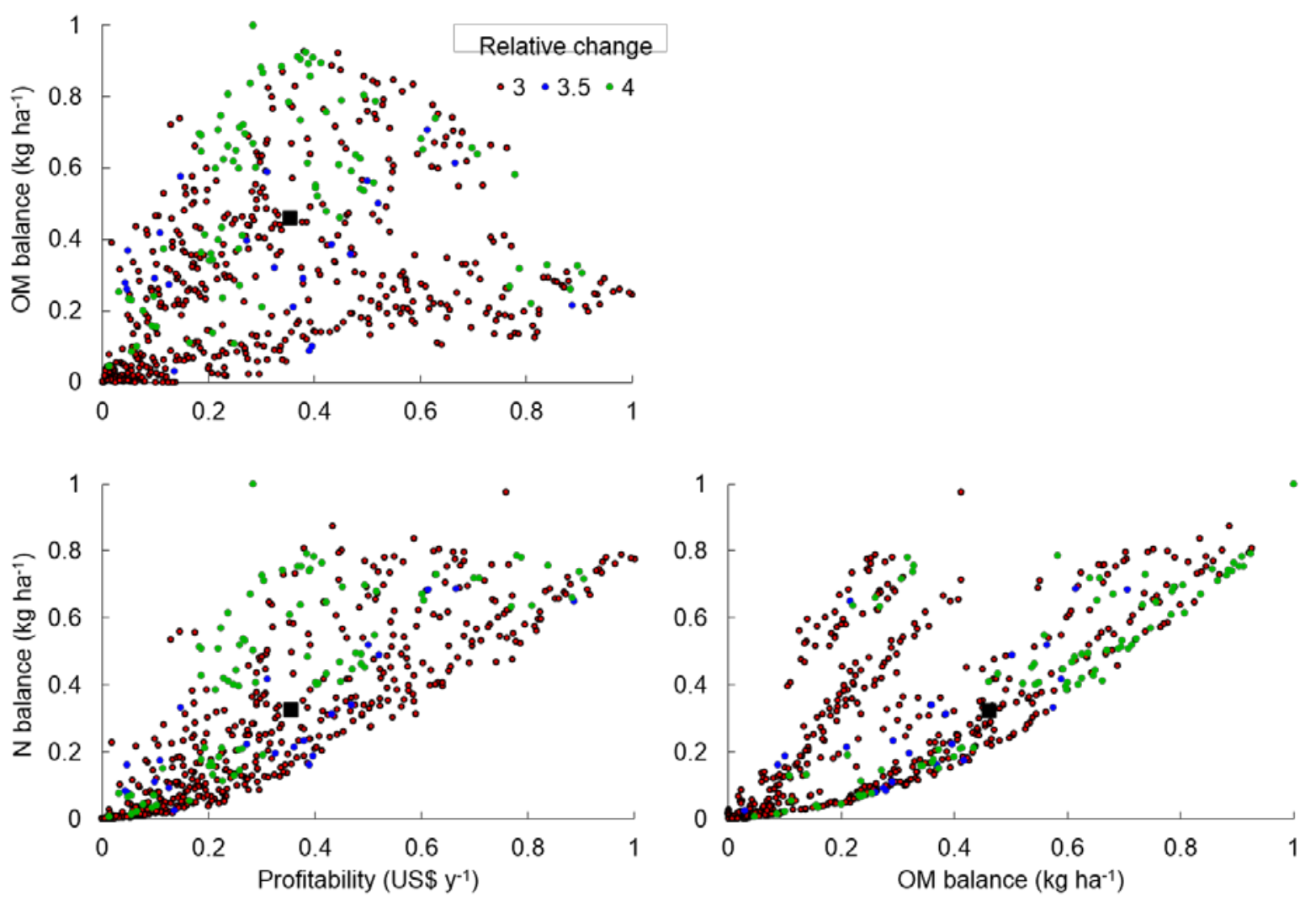

Figure 5.3. Required changes needed in decision variables compared to the starting position. Objectives variables are normalized for comparability by calculating for each alternative the difference with the starting position and dividing by the objective value range. Color codes describe the sum of squared normalized change in the decision variables compared to the starting position. Larger values indicate larger changes in management. The farm selected to illustrate resilience for SS is denoted by the black square symbol ( $\mathbf{m})$. 
Table 5.1. Characterization of the best alternatives for the objective variables: maximizing profitability (profit), organic matter balance (OM), and minimizing $\mathrm{N}$ balance $(\mathrm{N})$ of family-based (FB) and semi-specialized (SS) medium intensive (M) dairy farms in Marcos Castellanos, Michoacán, Mexico. The selection of the best alternative per group and system was based on the best value of the subset of alternatives of the exploration analysis.

\begin{tabular}{|c|c|c|c|c|c|c|c|c|}
\hline \multirow{2}{*}{ Variable } & \multicolumn{4}{|c|}{ FBM } & \multicolumn{4}{|c|}{ SSM } \\
\hline & Current & Profit & $\mathrm{OM}$ & $\mathrm{N}$ & Current & Profit & $\mathrm{OM}$ & $\mathrm{N}$ \\
\hline \multicolumn{9}{|l|}{ Land classification (ha) } \\
\hline Total area & 46.7 & 46.7 & 45.5 & 46.7 & 132.8 & 132.5 & 127.7 & 127.8 \\
\hline Rangeland & 44.5 & 44.5 & 43.3 & 44.5 & 109.6 & 109.4 & 104.6 & 104.7 \\
\hline Maize stover & --- & --- & --- & --- & 14.1 & 14.0 & 14.0 & 14.0 \\
\hline Maize silage & 2.2 & 2.2 & 2.2 & 2.2 & 9.1 & 9.1 & 9.1 & 9.1 \\
\hline Barley & --- & 0.86 & 0.58 & 0.01 & --- & 4.9 & 5.2 & 3.9 \\
\hline \multicolumn{9}{|l|}{$\underline{\text { Herd composition }}$} \\
\hline Cows $(\mathrm{Nr})$ & 24 & 24 & 24 & 24 & 92 & 114 & 110 & 72 \\
\hline Heifers (Nr) & 14 & 6 & 6 & 6 & 56 & 22 & 21 & 16 \\
\hline Calves (Nr) & 7 & 6 & 6 & 6 & 28 & 22 & 21 & 16 \\
\hline Herd size (Nr) & 45 & 36 & 36 & 36 & 176 & 158 & 152 & 104 \\
\hline Cows in herd (\%) & 53.3 & 66.9 & 66.7 & 66.6 & 52.3 & 72.4 & 72.0 & 69.0 \\
\hline \multicolumn{9}{|l|}{$\underline{\text { Ration composition }}$} \\
\hline Intake (kg DM LU ${ }^{-1} \mathrm{~d}^{-1}$ ) & 8.6 & 8.6 & 9.2 & 8.2 & 10.9 & 11.1 & 11.5 & 12.5 \\
\hline Concentrate (g kg ${ }^{-1}$ DMI) & 367 & 404 & 320 & 345 & 287 & 254 & 263 & 82 \\
\hline Forage ( $\left.\mathrm{g} \mathrm{kg}^{-1} \mathrm{DMI}\right)$ & 633 & 596 & 680 & 655 & 713 & 746 & 737 & 918 \\
\hline $\begin{array}{l}\text { External dependency ( } \mathrm{g} \mathrm{kg}^{-1} \\
\text { DMI) }\end{array}$ & 693 & 862 & 743 & 828 & 350 & 365 & 369 & 158 \\
\hline \multicolumn{9}{|l|}{ Productive variables } \\
\hline Stocking rate $\left(\mathrm{LU} \mathrm{ha}{ }^{-1}\right)^{1}$ & 0.75 & 0.62 & 0.63 & 0.62 & 1.05 & 1.00 & 1.01 & 0.69 \\
\hline Milk production (kg cow ${ }^{-1} \mathrm{~d}^{-1}$ ) & 10.0 & 10.5 & 9.3 & 8.6 & 9.0 & 11.7 & 11.7 & 11.7 \\
\hline Milk production $\left(\mathrm{Mg} \mathrm{y}^{-1}\right)$ & 87.3 & 92.4 & 81.6 & 75.0 & 302.2 & 484.8 & 471.2 & 308.6 \\
\hline Forage maize yield $\left(\mathrm{Mg} \mathrm{y}^{-1}\right)$ & 35.2 & 19.7 & 19.7 & 19.7 & 377.3 & 238.5 & 238.5 & 238.3 \\
\hline Forage maize sold $\left(\mathrm{Mg} \mathrm{y}^{-1}\right)$ & --- & 12.9 & --- & 8.1 & 91.4 & 27.3 & 23.3 & 23.6 \\
\hline Forage barley $\left(\mathrm{Mg} \mathrm{y}^{-1}\right)$ & --- & 2.6 & 1.7 & 0.0 & --- & 14.4 & 15.4 & 11.6 \\
\hline \multicolumn{9}{|l|}{ Objective variables } \\
\hline Profitability (US\$ thousands) & 9.7 & 12.8 & 9.1 & 9.1 & 22.6 & 64.8 & 53.3 & 36.4 \\
\hline OM balance (kg ha $\left.{ }^{-1}\right)$ & -813 & -815 & -789 & -814 & -670 & -628 & -597 & -658 \\
\hline $\mathrm{N}$ balance (kg ha ${ }^{-1}$ ) & 40 & 37 & 37 & 35 & 68 & 49 & 49 & 27 \\
\hline
\end{tabular}


Table 5.2. Vulnerability, resilience and net change of medium intensive family-based (FBM) and semispecialized (SSM) dairy farms in Marcos Castellanos, Michoacán, Mexico, after a perturbation of forage maize yield reduction and subsequent recovery by the inclusion of forage barley production and improved manure management, assessed considering profitability (US\$ $\mathrm{y}^{-1}$ ), organic matter balance (OM, kg ha ${ }^{-1}$ ) and nitrogen balance $\left(\mathrm{N}, \mathrm{kg} \mathrm{ha}^{-1}\right)$ as objective variables.

\begin{tabular}{|c|c|c|c|c|c|c|}
\hline \multirow{2}{*}{ Variable } & \multicolumn{3}{|c|}{ FBM } & \multicolumn{3}{|c|}{ SSM } \\
\hline & Profitability & OM balance & $\mathrm{N}$ balance & Profitability & OM balance & $\mathrm{N}$ balance \\
\hline \multicolumn{7}{|l|}{$\underline{\text { Condition assessed }}$} \\
\hline Original values & 9712 & -813 & 40 & 22557 & -670 & 68 \\
\hline After perturbation & 8865 & -831 & 41 & -2800 & -710 & 75 \\
\hline Selected configuration & 11169 & -795 & 37 & 57398 & -601 & 49 \\
\hline \multicolumn{7}{|l|}{ Variables estimated } \\
\hline Vulnerability (v) & -847 & -18 & 1 & -25357 & -40 & 7 \\
\hline Recovery (r) & 2304 & 36 & -4 & 60198 & 109 & -26 \\
\hline Resilience (R=r/v) & 2.7 & 2.0 & 4.0 & 2.4 & 2.7 & 3.7 \\
\hline
\end{tabular}

\subsection{Discussion}

Socio-ecological systems are highly influenced by the human capacity to reduce vulnerability by controlling disturbances and managing adaptive capacity (Walker et al., 2006; Gitz and Meybeck, 2012). Although these are dynamic systems influenced by external factors and internal components and the interaction of biotic and abiotic variables, farmers, technicians and governments interfere intentionally in this dynamic and in the direction of changes by decision making. The exploration of alternatives might support governments in the definition of policies, technicians in the search of solutions, and farmers in the implementation of changes all aimed at increasing or improving the adaptability of the systems.

By applying the presented framework to vulnerability and resilience assessment, these concepts lose abstractness by showing concrete and numerical changes that quantify and explain farm performance, and potential effects of both disturbances and a broad range of possible responses. The outcomes of the vulnerability assessment showed that both dairy farm systems were able to absorb the effects of the shock disturbance of reduced on-farm maize productivity. The vulnerability was assessed as the magnitude of the change of the performance indicators between the farm before and after the disturbance. Vulnerability was larger for the SS farm than for the FB farm, in particular in terms of profitability and to a lesser extent OM balance (Figure 5.2). The FB farm depended less on on-farm produced maize (and thus had a larger reliance on externally sourced feeds), which resulted a better capacity to absorb the effect of on-farm forage maize production reduction than for SS in our scenario. 
This scenario is valid under the current system delineation of the farm that considers markets and product prices external to the system. However, in the actual situation the impact on profitability will also depend on the changes in maize fodder prices that could occur when the disturbance affects not only the farm under study but reduces maize productivity at a larger scale.

The set of alternatives obtained during the exploration process showed the capacity of the farms to adjust their subsystems to the disturbance by reconfiguring their resources and diversifying the farm's production. The buffer capacity was larger for SS than for FB due to its higher diversity of available resources and greater deficiencies in baseline farm performance including factors such as poor herd structure and low milk production and crop productivity. The adaptive capacity increased after inclusion of the new management practices of forage barley cultivation after maize and manure application by enhancing the possibilities for mitigating the negative effects of the disturbance on the objective variables. The potential P of the SS farm was larger than that of FB, mainly for minimizing the $\mathrm{N}$ balance, which was the indicator that improved the most after implementation of the alternative of management. Both farms could adjust their management by reconfiguring and adjusting the management of already available resources. For maximizing profitability, SS had to intensify by increasing milk production and productivity, and sales of products (milk and maize forage). On the other hand, FB had to intensify its milk production and to diversify its sales, adding maize forage, although this implied increasing the external dependency of feedstuffs. Regarding this aspect, Gitz and Meybeck (2012) mentioned that the greater is the diversification of a system the higher the enhancement of resilience against disturbances, offering more alternatives to manage the impacts.

Generating multiple collections of snap-shots to create a timeline of changes in system performance and windows of opportunities, as done in our framework, can make the analysis with a static bioeconomic model semi-dynamic. However, the inherent limitations of static models remain, i.e. the importance of the system state for the response to disturbance is not addressed, and the dynamics and feedbacks cannot be incorporated directly. Nevertheless, that analytical framework can be readily coupled to more complex dynamic and event-driven models. Another limitation of the illustration presented here is that it only comprised the scales of field and farm, whereas larger landscape and community studies would also be useful and relevant to assess the influence of cooperative decisionmaking and of policies and institutions. Possible extensions include the evaluation of scenarios of change in the external drivers such as climatic change, demographic change, and changes in socioinstitutional conditions (prices and policies), cf. Groot and Rossing (2011).

To illustrate our concept, we only considered a single shock disturbance to assess vulnerability, one alternative to analyze resilience and three objective variables. Nevertheless, due to the many factors and interactions between subsystems the analyses revealed to contain rich complexity, which would be difficult to assess with simple conceptual models as it is commonly proposed (Carpenter et al., 2001; Walker et al., 2006; Darnhofer et al., 2010; Gitz and Meybeck, 2012). While conceptual models 
support the analysis by understanding the structures and functions of the systems under assessment, model-based quantitative analysis can enrich the analysis by demonstrating links between subsystems and considering social, economic, and environmental performance of systems after disturbance.

\subsection{Conclusion}

We presented a framework for quantitative analysis of vulnerability and resilience of farming systems, based on a multi-objective explorative whole-farm model that revealed buffer and adaptive capacities of the two case study farms. The results express vulnerability and resilience in terms relevant for farm assessment, thus reducing abstractness of the notions and providing leverage points for on-farm adaption. Yet, generating meaningful analyses requires a close collaboration between farmers and researchers to gather relevant and accurate information to build the mental models, to define the objectives, to parameterize the simulation model, and to identify the salient disturbances and alternative practices in order to increase the buffer and adaptive capacities.

The results of the study show that a simple reconfiguration can play an important role in reducing the impact of disturbances and in increasing the potential capacity of the systems. However, taking advantage of system resilience may require considerable change in practices and will draw on skills, motivation and learning capacity of the farmer.

\subsection{Acknowledgements}

We are very grateful to the farmers that made this work possible. This research was funded by the EULACIAS project (EU FP6- 5832004-INCO-dev-3; contract nr 032387).

\subsection{References}

Anderies, J.M., Janssen, M.A., and Ostrom, E., 2004. A framework to analyze the robustness of social-ecological systems from an institutional perspective. Ecology and Society, 9(1): 18.

Auger, A., Bader, J., Brockhoff, D., and Zitzler, E., 2012. Hypervolume-based multiobjective optimization: Theoretical foundations and practical implications. Theoretical Computer Science 425: $75-103$.

Beisner, B.E., Haydon, D.T., and Cuddington, K., 2003. Alternative stable states in ecology. Frontiers in Ecology and the Environment 1: 376 - 382.

Brand, F.S., and Jax, K., 2007. Focusing the Meaning(s) of Resilience: Resilience as a Descriptive Concept and a Boundary Object. Ecology and Society 12(1): 23. 
Carpenter, S., Walker, B., Anderies, J.M., and Abel, N., 2001. From metaphor to measurement: resilience of what to what?. Ecosystems 4: $765-781$.

Cortez-Arriola, J., Groot, J.C.J., Améndola M., R.D., Scholberg, J.M.S., Mariscal A., D.V., Tittonell, P., and Rossing, W.A.H., 2014. Resource use efficiency and farm productivity gaps of smallholder dairy farming in North-west Michoacán, Mexico. Agricultural Systems 126:15 24. http://dx.doi.org/10.1016/j.agsy.2013.11.001.

Cortez-Arriola, J., Rossing, W.A.H., Améndola M., R.D., Scholberg, J.M.S., Groot, J.C.J., and Tittonell, P., 2015. Leverages for on-farm innovation from farm typologies? An illustration for family-based dairy farms in north-west Michoacán, Mexico. Agricultural Systems 135: 66 - 76. http://dx.doi.org/10.1016/j.agsy.2014.12.005.

Darnhofer, I., Moller, H., and Fairweather, J., 2008. Farm resilience for sustainable food production: A conceptual framework.

In: http://researcharchive.lincoln.ac.nz/dspace/bitstream/10182/4295/1/farm_resilience.pdf. Retrieved: January, 2013.

Darnhofer, I., Fairweather, J., and Moller, H., 2010. Assessing a farm's sustainability: insights from resilience thinking. International Journal of Agricultural Sustainability 8(3): 186 - 198.

Eakin, H., Benessaiah, K., Barrera, J.F., Cruz-Bello, G.M., and Morales, H., 2012. Livelihoods and landscapes at the threshold of change: disaster and resilience in a Chiapas coffee community. Regional Environmental Change 12(3): 475 - 488.

Folk, C., Carpenter, S., Walker, B., Scheffer, M., Elmqvist, T., Gunderson, L., and Holling, C.S., 2004. Regime Shifts, Resilience, and Biodiversity in Ecosystem Management. Annual Review of Ecology, Evolution, and Systematics 35: 557 - 581.

Gitz,V., and Meybeck, A., 2012. Risks, vulnerabilities and resilience in a context of climate change. in: FAO/OECD Workshop: Building resilience for adaptation to climate change in the $\begin{array}{lllll}\text { agricultural } & \text { sector, } & \text { Rome, } & \text { Italy, }\end{array}$ http:/typo3.fao.org/fileadmin/templates/agphome/documents/faooecd/gitz.pdf. Retrieved: January, 2013.

Gornall, J., Betts, R., Burke, E., Clark, R., Camp, J., Willett, K., and Wiltshire, A., 2010. Implications of climate change for agricultural productivity in the early twenty-first century. Philosophical Transactions of the Royal Society, Series B, Biological Sciences 365: 2973 - 2989.

Groot, J.C.J., Rossing, W.A.H., Latinga, E.A, and Van Keulen, H., 2003. Exploring the potential for improved internal nutrient cycling in dairy farming systems, using an eco-mathematical model. NJAS 51(1/2): 165 - 194

Groot, J.C.J., and Rossing, W.A.H., 2011. Model-aided learning for adaptive management of natural resources: an evolutionary design perspective. Methods in Ecology and Evolution 2(6): 643 650. 
Groot, J.C.J., Oomen, G.J.M, and Rossing, W.A.H., 2012. Multi-objective optimization and design of farming systems. Agricultural Systems 110: 63 - 77.

Holling, C.S., 1986. Resilience of ecosystems; local surprise and global change. In: Clark WC, Munn RE, editors. Sustainable development of the biosphere. Cambridge (UK): Cambridge University Press. 292-317. Reprinted in: Cleveland C, Costanza R, Perrings C, editors. 1997. The development of ecological economics. Brookfields: Edward Elgar Publishing.

Holling, C.S., 2001. Understanding the complexity of economic, ecological and social systems. Ecosystems 4: 390 - 405.

Ifejika S., C., 2013. Buffer capacity: capturing a dimension of resilience to climate change in African smallholder agriculture. Regional Environmental Change. doi: 10.1007/s10113-012-0391-5.

Janssen, S., and Van Ittersum, M.K., 2007. Assessing farm innovations and responses to policies: a review of bio-economic farm models. Agricultural Systems 94(3): 622 - 636.

Lizárraga del C., G., Aguayo A., A., Garza T., R., and Peñuñuri M., F., 1980. Comparación de la producción de forraje de ballico italiano (Lolium multiflorum lam) y cebada forrajera (Hordeum vulgare L.) solos y asociados. Técnica Pecuaria México 39: 17 - 24.

Luers, A.L., Lobell, D.B., Sklar, L.C., Addams, C.L., and Matson, P.A., 2003. A method for quantifying vulnerability, applied to the agricultural system of the Yaqui Valley, Mexico. Global Environmental Change 13: 255 - 267.

Luers, A.L., 2005. The surface of vulnerability: An analytical framework for examining environmental change. Global Environmental Changes 15: 214 - 223.

Meinke, H., Howden, S. M., Struik, P. C., Nelson, R., Rodriguez, D., and Chapman, S. C., 2009. Adaptation science for agriculture and natural resource management-urgency and theoretical basis. Current Opinion in Environmental Sustainability 1: 69 - 76.

Milestad, R., and Darnhofer, I., 2003. Building farm resilience: the prospects and challenges of organic farming. Journal of Sustainable Agriculture 22: 81 - 97.

Miller, F., Osbahr, H., Boyd, E., Thomalla, F., Bharwani, S., Ziervogel, G., Walker, B., Birkmann, J., Van der Leeuw, S., Rockström, J., Hinkel, J., Downing, T., Folke, C., and Nelson, D., 2010. Resilience and vulnerability: Complementary or conflicting concepts?. Ecology and Society 15(3): 11.

Power, B., Rodriguez, D., DeVoil, P., Harris, G., and Payero, J., 2011. A multi-field bio-economic model of irrigated grain-cotton farming systems. Field Crops Research 124(2): 171 - 179.

Scheffer, M., Brock, W., and Westley, F., 2000. Socioeconomic mechanisms preventing optimum use of ecosystem services: an interdisciplinary theoretical analysis. Ecosystems 3: 451 - 471.

Scheffer, M., Carpenter, S., Foley, J.A., Folke, C., and Walker, B., 2001. Catastrophic shifts in ecosystems. Nature 413: 591 - 596. 
Secretaría de Gobierno, 2010. H. Ayuntamiento Constitucional de Marcos Castellanos: Plan de Desarrollo Municipal. Periódico Oficial del Gobierno Constitucional del Estado de Michoacán de Ocampo, Tomo CXLIX, Núm. 46. 16 p.

Shah, G.A., Groot, J.C.J., Shah, G.M., and Lantinga, E.A., 2013. Simulation of long-term carbon and nitrogen dynamics in grassland-based dairy farming systems to evaluate mitigation strategies for nutrient losses. PloS One 8(6): e67279.

Suding, K.N., Gross, K.L., and Houseman, G.R., 2004. Alternative states and positive feedbacks in restoration ecology. Trends in Ecology \& Evolution 19: 46 - 53.

Suweis, S., Carr, J.A., Maritan, A., Rinaldo, A., and D’Odorico, P., 2015. Resilience and reactivity of global food security. Proceedings of the National Academy of Sciences, USA 112(22): 6902 6907.

Tittonell, P., 2014. Livelihood strategies, resilience and transformability in African agroecosystems. Agricultural Systems 126:3-14.

Walker, B., Gunderson, L., Kinzig, A., Folke, C., Carpenter, S., and Schultz, L., 2006. A handful of heuristics and some propositions for understanding resilience in social-ecological systems. Ecology and Society, 11(1): 13.

Walker, B.H., Abel, N., Anderies, J.M., and Ryan, P., 2009. Resilience, adaptability, and transformability in the Goulburn-Broken catchment, Australia. Ecology and Society 14(1): 12.

Walker, B., Sayer, J., Andrew, N.L., and Campbell, B., 2010. Should enhance resilience be an objective of natural resource management research for developing countries?. Crop Sci. 50: S10 - S-19. 


\section{Supplementary material}

Table 5.S1. Decision variables (inputs and outcomes of the model) and constrains defined for the multi-objective optimization of the Family-based medium-intensive farm (FBM) for current performance analysis.

\begin{tabular}{|c|c|c|c|}
\hline Decision variable & Original $^{\S}$ & Minimum $^{\S \S}$ & Maximum $^{\S \S}$ \\
\hline \multicolumn{4}{|l|}{$\underline{\text { Decision variables }}$} \\
\hline Rangeland area (ha) & 46.7 & 40.6 & 46.8 \\
\hline Pasture area (ha) & 44.5 & 39.5 & 44.5 \\
\hline Cropland area (ha) & 2.2 & 1.1 & 2.2 \\
\hline Concentrate 1 (kg DM) & $818(1)$ & $0(0)$ & $50000(1)$ \\
\hline Concentrate 2 (kg DM) & $6868(0.87)$ & $0(0)$ & $50000(1)$ \\
\hline Concentrate 3 (kg DM) & $36(0)$ & $0(0)$ & $50000(1)$ \\
\hline Concentrate 4 (kg DM) & $22709(0.75)$ & $0(0)$ & $50000(1)$ \\
\hline Concentrate 5 (kg DM) & $1246(0.72)$ & $0(0)$ & $50000(1)$ \\
\hline Concentrate 6 (kg DM) & $897(1)$ & $0(0)$ & $50000(1)$ \\
\hline Concentrate 7 (kg DM) & $1375(0.22)$ & $0(0)$ & $50000(1)$ \\
\hline Concentrate 8 (kg DM) & $2628(0)$ & $0(0)$ & $50000(1)$ \\
\hline Concentrate 9 (kg DM) & $1584(0)$ & $0(0)$ & $50000(1)$ \\
\hline Milk (kg DM) & $135(0.41)$ & $134(0.40)$ & $255(0.60)$ \\
\hline Whey (kg DM) & $1272(1)$ & $0(0)$ & $1280(1)$ \\
\hline Alfalfa hay (kg DM) & $5582(1)$ & $0(0)$ & $17000(1)$ \\
\hline Mineral supplement (kg) & $1209(0.41)$ & $1050(0.40)$ & $1680(0.60)$ \\
\hline Maize stover (kg DM) & $5193(1)$ & $0(0)$ & $30000(1)$ \\
\hline Maize silage (kg DM) & $29715(0.95)$ & $0(0)$ & $32000(1)$ \\
\hline Calves (Nr) & 7 & 5 & 9 \\
\hline Heifers (Nr) & 14 & 10 & 18 \\
\hline Cows (Nr) & 24 & 20 & 28 \\
\hline
\end{tabular}




\section{Table 5.S1. Continued}

\section{Constraints}

Farm area (ha)

46.7

40.6

46.8

Intake in rainy season (\%)

$-35$

$-999$

0

$\mathrm{ME}$ in rainy season (\%)

$-17$

$-18$

10

$\mathrm{CP}$ in rainy season (\%)

$-17$

$-18$

10

Intake in dry season (\%)

$-39$

$-999$

0

ME in dry season (\%)

13

$-10$

14

$\mathrm{CP}$ in dry season (\%)

$-13$

$-14$

10

OM balance (kg ha $\left.{ }^{-1}\right)$

$-813$

$-820$

9999

$\mathrm{N}$ balance $\left(\mathrm{kg} \mathrm{ha}^{-1}\right.$ )

P balance (kg ha ${ }^{-1}$ )

K balance (kg ha ${ }^{-1}$ )

5

9

Labor balance (h)

$-380$

0

999

5

0

999

0

999

Operating profit (US\$)

9712

$-570$

$-250$

Feeding costs (US\$)

22523

$-1545$

77251

9009

29691

$\S$ The data without brackets are the absolute values of the variables of the original farm configuration, and the data between brackets are the proportion of the variable used in dry season.

$\S \S$ The data without brackets are the threshold values (minimum and maximum) for the variables in their original units, and the data between brackets are the threshold values (minimum and maximum) for the proportion to be used in dry season. 
Table 5.S2. Decision variables (inputs and outcomes of the model) and constrains defined for the multi-objective optimization of the Semi-specialized medium-intensive farm (SSM) for current performance analysis.

\begin{tabular}{|c|c|c|c|}
\hline Decision variable & Original $^{\S}$ & Minimum $^{\S \S}$ & Maximum $^{\S \S}$ \\
\hline \multicolumn{4}{|l|}{ Decision variables } \\
\hline Rangeland area (ha) & 109.6 & 104.6 & 109.7 \\
\hline Maize silage area (ha) & 9.1 & 5.0 & 9.1 \\
\hline Maize stover area (ha) & 14.1 & 9.0 & 14.1 \\
\hline Concentrate 1 (kg DM) & $326(0)$ & $0(0)$ & $45000(0.70)$ \\
\hline Concentrate 2 (kg DM) & $44993(0.71)$ & $0(0)$ & $80000(0.78)$ \\
\hline Concentrate 3 (kg DM) & $1218(0.84)$ & $0(0)$ & $15000(1)$ \\
\hline Concentrate 4 (kg DM) & $36(0)$ & $0(0)$ & $35000(1)$ \\
\hline Concentrate 5 (kg DM) & $3556(0.59)$ & $3556(0.4)$ & $20000(0.6)$ \\
\hline Concentrate 6 (kg DM) & $402(1)$ & $0(0)$ & $15000(1)$ \\
\hline Concentrate 7 (kg DM) & 1118 (0.59) & $1118(0.4)$ & $1500(0.6)$ \\
\hline Concentrate 8 (kg DM) & 709 (0.59) & $0(0.4)$ & $2000(0.6)$ \\
\hline Concentrate 9 (kg DM) & $1200(0.59)$ & $1200(0.4)$ & $2000(0.6)$ \\
\hline Concentrate 10 (kg DM) & $6088(0.45)$ & $0(0.4)$ & $6100(0.6)$ \\
\hline Concentrate 11 (kg DM) & $995(1)$ & $0(0)$ & $5000(1)$ \\
\hline Concentrate 12 (kg DM) & $45913(0.7)$ & $0(0)$ & $80000(0.75)$ \\
\hline Concentrate 13 (kg DM) & $37240(0.35)$ & $0(0)$ & $80000(1)$ \\
\hline Concentrate 14 (kg DM) & $2732(0.10)$ & $0(0)$ & $15000(1)$ \\
\hline Concentrate 15 (kg DM) & $4788(0.88)$ & $0(0)$ & $15000(1)$ \\
\hline Concentrate 16 (kg DM) & $5134(0.61)$ & $0(0)$ & $6000(1)$ \\
\hline Concentrate 17 (kg DM) & $511(0)$ & $0(0)$ & $2000(1)$ \\
\hline Concentrate 18 (kg DM) & 716 & 715.5 & 716 \\
\hline Concentrate 19 (kg DM) & $588(0.41)$ & $587.5(0.41)$ & $588(0.41)$ \\
\hline Concentrate 20 (kg DM) & $361(0.38)$ & $360.8(0.37)$ & $361(0.38)$ \\
\hline Milk (kg DM) & $300(0.6)$ & $300(0.4)$ & $758(0.6)$ \\
\hline Whey (kg DM) & 2002 (0.59) & $0(0.4)$ & $3000(0.6)$ \\
\hline Chickpea hay (kg DM) & $23067(1)$ & $0(0)$ & $30000(1)$ \\
\hline Alfalfa hay (kg DM) & $1341(0.4)$ & $0(0)$ & $30000(1)$ \\
\hline Maize stover (kg DM) & $121389(0.62)$ & $0(0)$ & $160000(1)$ \\
\hline Maize silage (kg DM) & $137823(0.95)$ & $0(0)$ & $138000(1)$ \\
\hline Calves (Nr) & 28 & 25 & 35 \\
\hline Heifers (Nr) & 56 & 42 & 70 \\
\hline Cows (Nr) & 92 & 70 & 115 \\
\hline
\end{tabular}




\section{Table 5.S2. Continued}

\section{$\underline{\text { Constraints }}$}

Farm area (ha)

Intake in rainy season (\%)

ME in rainy season (\%)

$\mathrm{CP}$ in rainy season (\%)

Intake in dry season (\%)

ME in dry season (\%)

$\mathrm{CP}$ in dry season (\%)

OM balance (kg ha ${ }^{-1}$ )

$\mathrm{N}$ balance ( $\mathrm{kg} \mathrm{ha}^{-1}$ )

P balance (kg ha $\left.{ }^{-1}\right)$

K balance ( $\mathrm{kg} \mathrm{ha}^{-1}$ )

Labor balance (h)

Operating profit (US\$)

Feeding costs (US\$)
132.8

$-19.0$

8.0

20

$-18.0$

21

$-2$

$-670$

68

2

16

4553

22557

97791
94.2

$-999$

$-10$

$-10$

$-999$

$-10$

$-10$

$-671$

0

0

0

2000

$-1545$

39117
133.0

0

10

21

0

21

10

9999

999

999

999

6000

77251

146687

$\S$ The data without brackets are the absolute values of the variables of the original farm configuration, and the data between brackets are the proportion of the variable used in dry season.

$\S \S$ The numbers without brackets are the threshold values (minimum and maximum) of the variables in their original units, and the numbers between brackets are the threshold values (minimum and maximum) for the proportion to be used in dry season.

Table 5.S3. Forage maize production, crop management, and precipitation on medium intensive family-based medium-intensive (FBM) and semi-specialized medium-intensive (SSM) dairy farms in Marcos Castellanos, Michoacán, Mexico, in 2008-2009 and 2009-2010.

\begin{tabular}{|c|c|c|c|c|}
\hline \multirow{2}{*}{ Variable } & \multicolumn{2}{|c|}{ FBM } & \multicolumn{2}{|c|}{ SSM } \\
\hline & 2008-2009 & $2009-2010$ & 2008-2009 & $2009-2010$ \\
\hline Seed maize variety & Mareño & Barriga & Creole seeds & Matador \\
\hline Seeding $\left(\mathrm{kg} \mathrm{ha}^{-1}\right)$ & 29.1 & 36.4 & 21.6 & 27.6 \\
\hline Nitrogen $\left(\mathrm{kg} \mathrm{ha}^{-1}\right)$ & 104 & 129 & 182 & 217 \\
\hline Phosphorus (kg ha ${ }^{-1}$ ) & 10.4 & 41.8 & 0.0 & 0.0 \\
\hline Forage maize yield (t DM ha ${ }^{-1}$ ) & 10.6 & 16.0 & 11.1 & 16.3 \\
\hline Fall armyworm & Lack of control & Controlled & Lack of control & Controlled \\
\hline Precipitation (mm) & 717 & 605 & 678 & 652 \\
\hline
\end{tabular}


Table 5.S4. Decision variables (inputs and constrains) modified during the exploration of alternatives for Family-based (FB) and Semi-specialized (SS) medium-intensive (M) dairy farms systems located in Marcos Castellanos, Michoacán, Mexico for resilience analysis.

\begin{tabular}{|c|c|c|c|}
\hline Decision variable & Original $^{\S}$ & Minimum $^{\S \S}$ & Maximum $^{\S \S}$ \\
\hline \multicolumn{4}{|c|}{ FBM } \\
\hline Inputs of the model for resilienc & under reductio & aize productic & ect) \\
\hline Maize silage (kg DM) & $19710(0.95)$ & $0(0)$ & $20000(1)$ \\
\hline Barley forage (kg DM) & $0(0)$ & $0(0)$ & $6541(1)$ \\
\hline Milk production $\left(\mathrm{kg} \mathrm{cow}^{-1} \mathrm{~d}^{-1}\right)$ & 10 & 7 & 13 \\
\hline Replacement rate & 0.25 & 0.19 & 0.28 \\
\hline \multicolumn{4}{|l|}{ Outcomes of the model } \\
\hline Intake in rainy season (\%) & -24 & -999 & 0 \\
\hline ME in rainy season (\%) & -5 & -10 & 10 \\
\hline $\mathrm{CP}$ in rainy season (\%) & -9 & -10 & 10 \\
\hline Intake in dry season (\%) & -28 & -999 & 0 \\
\hline ME in dry season (\%) & 12 & -10 & 12.5 \\
\hline CP in dry season (\%) & -13 & -13.5 & 10 \\
\hline OM balance (kg ha $\left.{ }^{-1}\right)$ & -816 & -816 & 9999 \\
\hline $\mathrm{N}\left(\mathrm{kg} \mathrm{ha}^{-1}\right)$ & 37 & 0 & 999 \\
\hline Labor balance (h) & -479 & -719 & -335 \\
\hline Feeding costs (US\$) & 19794 & 7918 & 29691 \\
\hline Operating profit (US\$) & 8958 & -1545 & 77251 \\
\hline
\end{tabular}

Inputs of the model for resilience analysis under reduction of forage maize production (shock effect)

$\begin{array}{lccc}\text { Maize silage }(\mathrm{kg} \mathrm{DM}) & 93873(0.95) & 0(0) & 93900(1) \\ \text { Barley forage }(\mathrm{kg} \mathrm{DM}) & 0(0) & 0(0) & 27057(1) \\ \text { Milk production }\left(\mathrm{kg} \mathrm{cow}^{-1} \mathrm{~d}^{-1}\right) & 9 & 6.3 & 11.7 \\ \text { Replacement rate } & 0.25 & 0.19 & 0.28\end{array}$


Table 5.S4. Continued

$\begin{array}{lrrc}\text { Outcomes of the model } & & & \\ \text { Intake in rainy season (\%) } & -3 & -999 & 0 \\ \text { ME in rainy season (\%) } & 30 & -10 & 30.5 \\ \text { CP in rainy season (\%) } & 37 & -5 & 0 \\ \text { Intake in dry season (\%) } & -18 & -999 & 21.4 \\ \text { ME in dry season (\%) } & 21 & -10 & 10 \\ \text { CP in dry season (\%) } & -1 & -11 & 9999 \\ \text { OM balance (kg ha }{ }^{-1} \text { ) } & -685 & -686 & 999 \\ \text { N (kg ha }{ }^{-1} \text { ) } & 49 & 0 & 6083 \\ \text { Labor balance (h) } & 4361 & 39743 & 149038 \\ \text { Feeding costs (US\$) } & 99358 & -1545 & 77251 \\ \text { Operating profit (US\$) } & -1019 & \end{array}$

\footnotetext{
$\S$ The data without brackets are the absolute values of the variables of the original farm configuration, and the data between brackets are the proportion of the variable used in dry season.

$\S \S$ The numbers without brackets are the threshold values (minimum and maximum) of the variables in their original units, and the numbers between brackets are the threshold values (minimum and maximum) for the proportion to be used in dry season.
}

\section{Box S1}

\section{S1.1. Variables collected}

To characterize the current performance of the selected dairy farms, the management of the farms was monitored between July 2009 and June 2010. The information collected every fortnight included social, economic, and environmental aspects, of all farm management practices implemented at the crop and animal subsystems. At the crop subsystem, the information gathered was related to forage production and utilization, inputs, and labor demand, costs and allocation. At the animal subsystem, it included information pertaining to herd structure, milk production and marketing, body weight, dry matter intake (DMI), labor requirement, and sanitary and reproductive management. Additionally, to characterize soil physical and chemical properties and soil losses in grazing and cropping lands, soil sampling, groundcover, and runoff measurements were carried out during the rainy season. Samples of grazed and conserved forage, feedstuffs, milk produced, feces, urine, runoff, and soil were submitted to chemical analysis. It included crude protein $(\mathrm{CP})$, nitrogen $(\mathrm{N})$, phosphorus $(\mathrm{P})$, potassium $(\mathrm{K})$ content, total ashes, soil bulk density and organic C content, depending on the type of sample. One weather station Davis Vantage Pro2 ${ }^{\mathrm{TM}}$ was installed in each farm to record information related to temperature $\left({ }^{\circ} \mathrm{C}\right)$ and rainfall $(\mathrm{mm})$. 


\section{S1.2. Variable estimated and assumptions}

Some variables required to explore the alternatives were estimated indirectly or taken from the literature. Biological and non-symbiotic fixation were results reported by Cleveland et al. (1999) and Fatima et al. (2008). Atmospheric deposition of $\mathrm{N}$ was indirectly estimated according to Galloway et al. (2008), and $\mathrm{P}$ and $\mathrm{K}$ deposition were calculated as a function of the precipitation and their specific factors (Smaling and Fresco, 1993). Parameters to estimate DMI, ME, and CP requirements per type of animals of the herd structure were based on NRC standards (NRC 1989, 2001). ME requirements for lactating cows were estimated using an equation built specifically for the type of animals and management condition present of region (Améndola, 2008).

In the economic analysis, it was assumed that the opportunity cost of own land was on average the rental price per unit of land in the study region, while for the estimation of the family labor cost, it was considered the salary of a possible alternative occupation based on the skills of each family member that worked in the farm.

\section{S1.3. Exploratory tool used}

The inputs required for the model can be grouped in: biophysical environment (soil and climate); socio-economic (costs, and labor demand and prices); crops (diversity, production, nutrient composition, labor demand and costs); crop products (external feeding sources) (diversity, demand, costs, and nutrient composition); groups of animals and herd composition (diversity, management, productivity, and nutrient requirements); type of products of the farm (diversity, destination, prices, and composition); manure sources, deposition, and use (production, management, and use efficiency); external sources of mineral nutrients (diversity, amounts, composition, costs, and use efficiency), and physical assets (buildings and machinery).

Flows and balances of OM, N, P and K through and from a farm, nutrient balances of ME and CP, herd DMI, manure production and composition, and labor and economic balances are the outcomes of a static farm balance of the model. These variables were related to whole farm area, land use, crop products destination, animal requirement and production, and inputs and outputs of the farms.

For the exploration process, all the variables constrained are considered by the model as the decision variables to search optimal solutions based on the desired objectives. These objectives can be to minimize or to maximize specific outcomes. A complete description of the model was presented by Groot et al. (2012). 


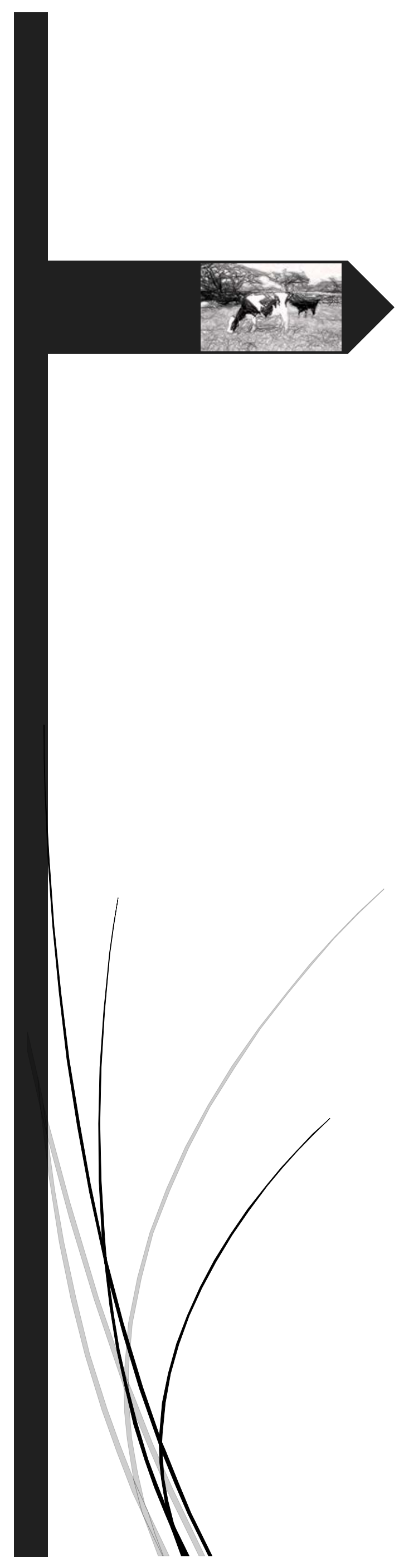

Chapter 6: General discussion 



\subsection{Introduction}

Traditionally, agriculture has been one of the main sources of employment, income and food for rural and agricultural population worldwide, particularly in developing countries. In 1990 the agricultural population still represented around $46 \%$ of the global population, but it is projected to drop to $36 \%$ by 2020, while urban populations will continue expanding by 1.8\% each year (FAOSTAT, 2012; Resources, PopSTAT, Annual time series). In Mexico, changes in agricultural population are even more pronounced and in 2010 farmers only accounted for 20.5\% of the total population with projected annual decreases of $1.9 \%$.

Taking into consideration that $75 \%$ of poor people in developing countries live in rural areas (World Bank, 2008), the population shift from rural communities and agricultural activities to urban centers is fueled by the search for alternative and more lucrative forms of employment. Traditionally, smallholder farmers combine agricultural activities with alternative income sources to complement the low income generated by agriculture (Cervantes and Cesín, 2007). Moreover, alternative employment options in rural areas tend to be limited while salaries tend to be very low, causing high rates of migration of males (SEGOB, 2010), family disintegration, and mostly women and children remaining to continue with farm activities.

Although, the productivity and profitability of livestock production systems have increased during the past decades due to technical improvements and increased global demands for livestock products (Vishwanath, 2003; Naylor et al., 2005; Hazell and Wood, 2008; Thornton, 2010), smallholders failed to benefit from this. This is related to poor access to markets, coupled with steep increases in production (feeding) costs, lack of infrastructure (buildings and equipment), and lack of knowledge to effectively utilize technical innovations. Thus, it is a challenge for policy makers to design and apply policies that contribute to the improvement of the productivity and profitability of smallholder-based dairy systems, and their sustainability, considering environmental, social, economic, and infrastructure and equipment limitations.

Until the first half of the 1980's, Mexican agricultural policies were aimed at protecting the national market and reaching self-sufficiency for maize and other food commodities. Probably, the most striking example was the state-owned Compañía Nacional de Subsistencias Populares (CONASUPO), established in 1965 to provide farmers with a secure market with guaranteed product prices. Due to the Latin-American debt crisis in 1982, Mexico was pressured to undertake neoliberal policies towards (open) market-driven economic strategies, leading to the dismantling of CONASUPO in 1989. As a consequence, prices became more dependent on global markets. In 1994, the North American Free Trade Agreement (NAFTA) between USA, Canada and Mexico was ratified with pronounced negative economic impacts on the Mexican maize and milk prices paid to local farmers. The USA are the fourth largest exporter of milk worldwide, and in the last decade it became the main supplier of powdered 
milk in Mexico (SE, 2012). This was favored by the gradual reduction and the complete liberalization of the tariff on imported milk powder in 2008, as part of the NAFTA. The large amount of imported milk caused a drop in the national milk price, with especially negative consequences for the revenues of smallholder dairy farmers (Lara-Covarrubias et al., 2003; Espinoza-Ortega et al., 2005).

To compensate the effects of NAFTA, the Mexican government has been implementing in the last 20 years the Direct Field Support Program (PROCAMPO). Even though the Organization for Economic Co-operation and Development (OECD) (2006) stated that this Program improved the effectiveness and efficiency of the prevailing agricultural policy measures, Zarazúa-Escobar et al. (2011) concluded that farmers that received this benefit still were forced to discontinue their agricultural activities at a high rate due to lack of profitability of their farms.

Additional to the issues and challenges mentioned above, smallholder dairy farmers face specific problems that affect their ecological sustainability, productivity and economic efficiency. As part of this, Aguilar and López (2006) mentioned low farm-gate milk prices, lack of technological training in farm management and marketing, poor milk quality, and lack of organization in farm cooperatives. Farmer organization is essential for improved negotiating power and farmers benefitting from economies of scale by securing production inputs at competitive prices and to ensure fair prices and improved marketing opportunities for their products.

Therefore, appropriate policies must be designed to address these issues and to achieve the sustainable intensification of the dairy farms providing technical support to the farmers while exploring and implementing viable alternatives based on their resources, skills and inherent constraints, and reducing environmental impacts. This requires strengthening the organization of farmers, promoting vertical integration - understanding it as the associative organization of farmers for production, access to the markets of inputs, milk processing, and commercialization (FAO, 2012) - and improved access to appropriate technologies and corresponding inputs. In this manner farmers would be able to add value to the milk produced, and increasing milk production while reducing environmental impacts (SAGARPA, 2008).

In this thesis, the environmental, social and economic performance of smallholder dairy farming were assessed in selected case studies in the Marcos Castellanos region of Michoacán State, Mexico, as a scientific basis to effectively explore viable alternatives to enhance overall farm sustainability. The overall aim was to support decision making of farmers and technical advisors, and to provide information to local government officials for the design of policies aimed at the improvement of farmers' livelihoods thereby reducing the migration of farmers from rural communities.

This chapter aims to synthesize and integrate the main results presented and discussed in the previous chapters, to highlight the most salient aspects. Moreover, it aims to provide guidelines and discuss practical implications for smallholder dairy farms while also providing guidelines for future research. 


\subsection{Procedure and mayor findings of the thesis}

\subsubsection{Overall procedure}

This study focused on sustainable intensification of smallholder dairy farms by analyzing the current situation and exploring different alternatives for improvements. To achieve this goal, we followed the methodological steps of the "DEED” (Describe, Explain, Explore and Design) farming systems analysis approach (Figure 6.1).

For the "describe" step and based on the results of a survey conducted among 97 dairy farmers (14.6\% of total population) in the study region, a farm typology was developed using multivariate analysis. This survey included information pertaining to biophysical and socio-economic resources along with basic farm management practices. The main farm types included two main dairy farm systems (family-based, FB vs semi-specialized, SS), with three levels of intensification each, expressed in terms of density of livestock units (LU). These levels included extensive (E, $<0.8 \mathrm{LU} \mathrm{ha}{ }^{-1}$ ), mediumintensive (M, between 0.8 and $1.2 \mathrm{LU} \mathrm{ha}^{-1}$ ), and intensive (I, > 1.2 LU ha ${ }^{-1}$ ) farming systems (Chapter 2).

Based on this typology, six representative dairy farms in each dairy system were selected for more detailed analysis, representing each level of intensification as shown in Figure 6.2.

Main scale

DEED steps

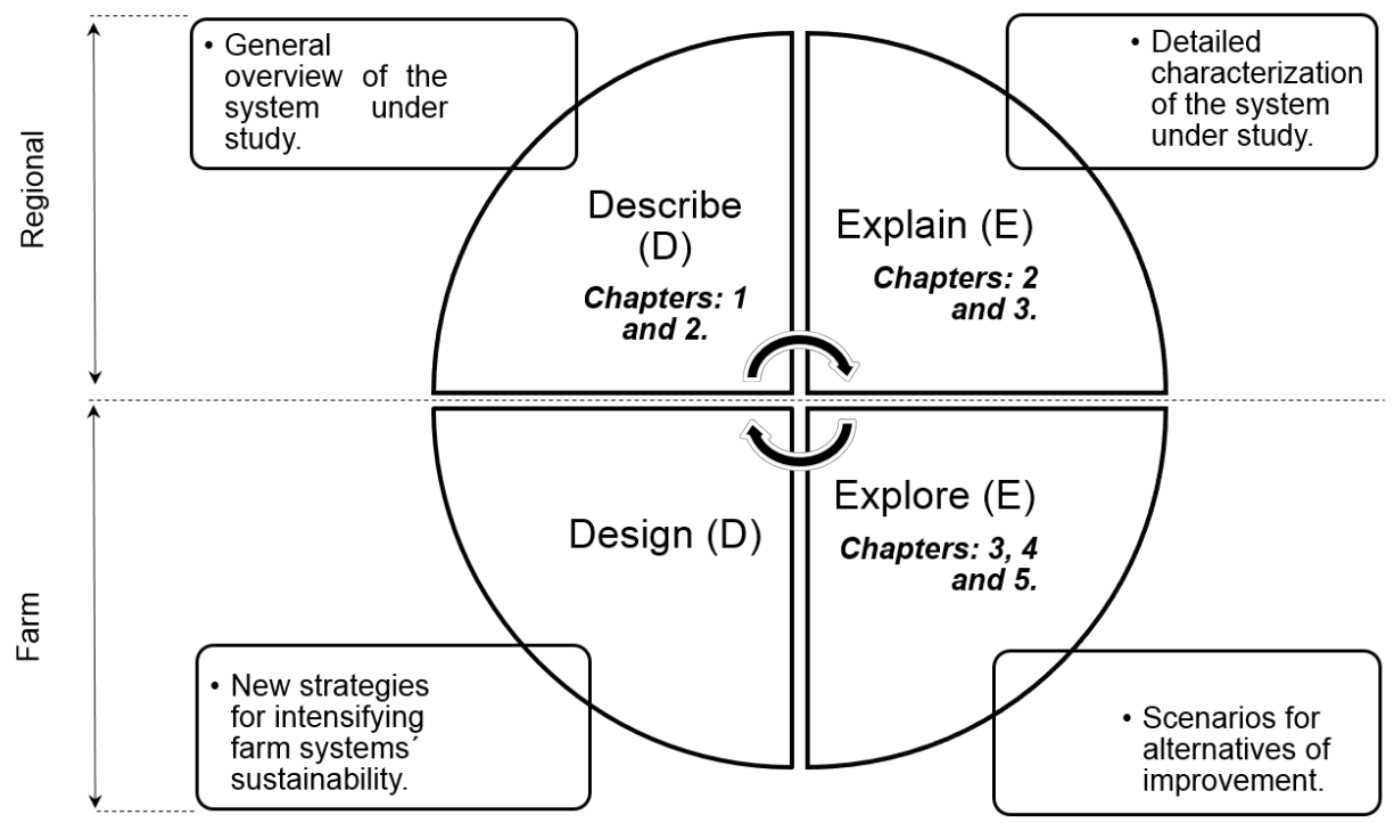

Figure 6.1. Relation between steps of the "DEED" (Describe, explain, explore and design) farming systems analysis approach (adapted from Tittonell, 2008) and the chapters of the thesis, and the main scale of the analysis. The results of the thesis inform the fourth step and are summarized as recommendations in this chapter. 


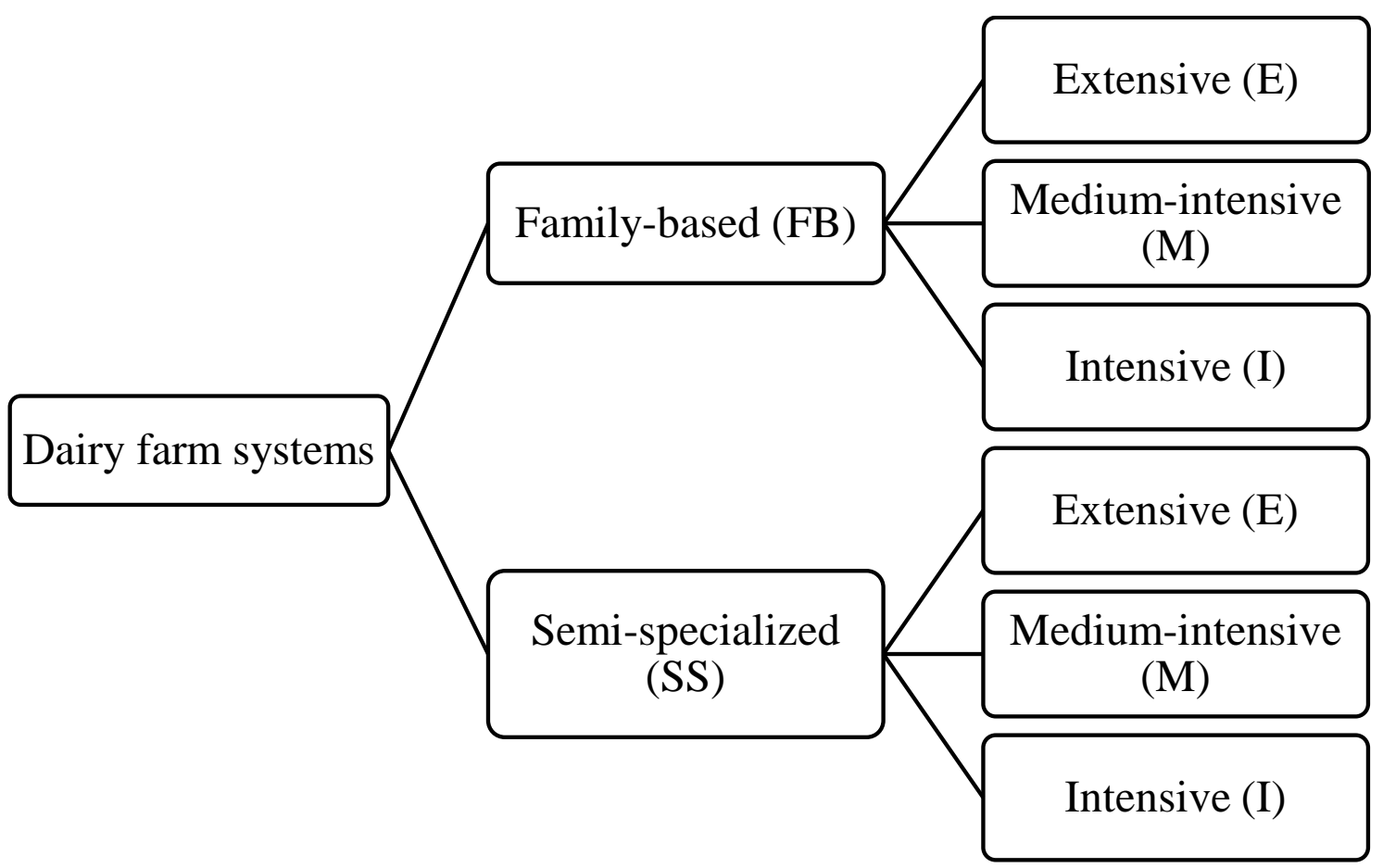

Figure 6.2. Farm typology of dairy farming systems based on a survey of smallholder dairy farmers in Marcos Castellanos, Michoacán, Mexico, in 2007. The overall farming system comprises two distinct dairy systems (family-based, FB; and, semi-specialized, SS) each with three levels of intensification (extensive, E; mediumintensive, M; and, intensive, I) based on actual livestock units per farm.

This dairy farm typology was used in the subsequent chapters of the thesis to assess the diversity of dairy farming in the study region, to estimate the gap between current and attainable farm milk yield, identifying the major factors that impact productivity of the dairy farms, as part of the second step of the DEED approach (Figure 6.1). The third step of this approach was implemented in chapter 4, where we explored alternatives of farm management for economic, environmental, and social improvements. The latter is beyond the scope of this thesis.

In chapter 5 we developed and applied a quantitative approach to analyze and assess vulnerability and resilience of agro-ecosystems. The approach aims to reduce subjectivity and abstractness of the current theoretical mental models on vulnerability and resilience in agricultural systems. By taking a quantitative approach the concept of resilience and vulnerability could be made operational to express changes through the time in key farm variables.

\subsubsection{Major findings}

From the cluster analysis implemented as part of the multivariate analysis, four groups were identified, two of them comprising the smaller farms and the other two the bigger dairy farms. The key differentiating factors that resulted from the survey were land area, herd size, hired labor, 
infrastructure and equipment (Chapter 2). The two groups of small farms had an average land area of 26.8 and 29.9 ha, respectively, an average herd size of $35 \mathrm{LU}$ for both groups, with family members as the main source of labor. These groups represented more than $86 \%$ of the farms in the survey, and were characterized by on average $77.5 \%$ of grazing land (Chapter 2, Table 2.3; Figure 2.1). The main difference within this family-based farm group was income diversification as in some cases farmers exclusively depended on farm income, while for the rest there were two or more alternative (external) sources of income. Overall characteristics of these types coincide with the family-based dairy farm type described by Amendola (2002) and Lara-Covarrubias (2003) at the national level. The two groups with the larger dairy farms featured farms with an average land area of 182 and 104 ha, and 144 and $70 \mathrm{LU}$, respectively, and a smaller proportion of family labor. These farmers invested more in infrastructure and equipment while they also paid more attention to animal health management than the family-based types (Chapter 2, Table 2.3). The main difference between the groups was related to farm and herd size, with farms tending to have bigger and fully mechanized milking parlors while also owning their own equipment for producing and harvesting forage maize. The characteristics of these two groups coincide with the SS dairy farm type described by Amendola (2002) and Lara-Covarrubias (2003).

Based on the sampled six pilot farms representative of different levels of intensifications for family based and semi-intensive systems (Chapter 2; Table 2.4), it was shown that overall milk productivity was low (between 2425 and $4339 \mathrm{~kg} \mathrm{cow}^{-1}$ lactation $^{-1}$ ). This was related to frequent incidence of mastitis, a relatively large fraction of non-productive animals, and inefficient reproduction management (Chapter 3; Table 3.2). Revenues per kg milk were similar among farms, except for the semi-specialized intensive farm, which achieved about $25 \%$ higher revenue per kg milk because of onfarm milk processing and direct sales (Chapter 2; Figures 2.4 and 2.6). Feed costs accounted for 50 to $70 \%$ of the total costs (Chapter 2; Table 2.5). The net margin was negative for all farms (Chapter 2; Figure 2.4). The gross margins for FBE, FBM, SSM and SSI farm types were around 0.09 US\$ $\mathrm{kg}^{-1}$ milk, while FBI and SSE had negative gross margins of up to $0.09 \mathrm{US \$} \mathrm{kg}^{-1}$ milk. This poor economic performance was the result of the high proportion of concentrates in the feed ration (28 to 53\% at farm level) (Chapter 3 and 4; Tables 3.4 and 4.1), and ineffective utilization of rangelands for grazing (contributing 16 to $49 \%$ of the ration) and on-farm produced forage maize (5 to $27 \%$ of the total land) (Chapters 4; Table 4.1). Overall differences in economic performance appeared to be mostly related to differences in production intensity while differences in feedstuff utilization patterns were relatively small between family-based and semi-specialized systems.

Grazing land was the predominant land-use, either as rangeland (with native species) or improved pastures (Chapter 3; Table 3.3). Only the most intensive farms (FBI and SSI) utilized improved and more productive pastures. The overall productivity of rangeland was very low (0.6 to $1.6 \mathrm{Mg} \mathrm{DM} \mathrm{ha}^{-1}$ year $^{-1}$ ), and although improved pastures had higher forage yield (2.8 to $3.4 \mathrm{Mg} \mathrm{DM} \mathrm{ha}^{-1}$ year $^{-1}$ ), the 
forage quality in terms of CP content was lower than for rangelands (Chapter 3; Table 3.3). On the other hand, cropland for forage maize occupied only between 5 and 23\% of the farm area. Maize was used for feeding own cattle and/or to sell as silage or stover (only FBI and SSM, respectively). In terms of maize forage production, yields ranged from 7.4 to $16.4 \mathrm{Mg} \mathrm{DM} \mathrm{ha}^{-1}$ across farms; the latter can be considered as a fair yield in the region (Chapter 3; Table 3.3).

Taking into consideration the wide differences between farms in farm management, forage yields, and milk, we estimated the effect of these differences expressed as farm yield gap for milk production. Partial farm yield gaps were calculated to attribute the milk yield gap to the 3 major differences with a reference farm of the same area and with the same number of lactating cows as the real farm counterpart: i) differences in herd management and livestock density, ii) differences in proportions of cultivated crop areas and iii) differences in crop productivity. The virtual reference farm was constructed by combining best performing crop and animal production activities as observed among the six pilot farms. The contribution of each component was calculated by sequentially changing the values used for the virtual farm to those of the real farm. As final result of this analysis, we compared the difference between milk production on the real farm and the milk production attainable on a virtual one. This analysis showed that the reference farms had an attainable milk yield of $2.7 \mathrm{Mg} \mathrm{ha}^{-1}$ on the basis of full feed self-supply, and $4.2 \mathrm{Mg} \mathrm{ha}^{-1}$ when the crude protein limitation in the ration was resolved (Chapter 3; Figure 3.1). Compared to the reference farm actual milk yields were on average $78 \%$ lower on family based farms and 58\% lower on semi-specialized farms. There was not a single or consistent cause governing the yield gap among different farms, and key production limitations differed greatly across farms. The overall average reduction could be attributed almost equally to poor herd management (18\%), suboptimal allocation of crops and/or feedstuffs (23\%) and low inherent crop productivity (26\%) (Chapter 3; Figure 3.1).

Trying to find alternative intensification options to improve the performance of farms by reallocating farm endowments, changing areas of crops and animal numbers, while keeping the same production systems, we used the FarmDESIGN model to quantify farm production, economic and environmental performance and explore alternatives of improvement as windows of opportunities. This analysis showed that the six dairy farm systems analyzed have different options for improvement when only changing tactical and practical decisions. Within the set of viable alternatives per farm three functional groups were identified (Chapter 4; Figure 4.1). These groups of solutions were denoted as 'economic' for alternatives that prioritized profitability, 'environmental' for alternatives that prioritized OM balance, and 'integrated' for alternatives that combined minimization of labor use (a socio-economic variable), with reduced excessive $\mathrm{N}$ loading (environmental) and feeding costs (economic). Overall, 'integrated' alternatives constituted the majority for the FBE, FBI, SSE and SSI farm types while 'economic' ones occurred less frequently.

Considering that agricultural systems are at risk of being affected by disturbances ranging over 
multiple spatial and temporal scales, we presented a generic quantitative approach to analyze and assess system vulnerability and resilience to a specific disturbance. Current analyses of vulnerability and resilience are based on different theoretical mental models and practical approaches (Darnhofer et al., 2010; Eakin et al., 2012; Gitz and Meybeck, 2012; Ifejika, 2013; Tittonell, 2014), while farmers, technicians, and policy makers need more quantitative approaches for a better understanding. In agricultural systems Gitz and Meybeck (2012) classified disturbances into economic and access to markets, climatic, and management practices. Such disturbances negatively impact system productivity and profitability. Therefore, in a first step we assessed the vulnerability of one FB and one SS dairy farm to forage maize yield reduction due to changes in crop management and the incidence of fall armyworm (Spodoptera frugiperda). In a second step, we assessed the resilience of the dairy farms by adding a new forage crop, associated with forage maize production, and recycling the manure produced in the farms. The assumed yield decline following a disturbance negatively impacted profitability and soil organic matter on both farms. It appeared that the SS farm was better equipped to address this adversity and showed greater ability for recovery, i.e. had greater resilience, compared to the FB farm. Greater resilience was linked to better buffering and adaptive capacity. Clear tradeoffs were found between minimizing $\mathrm{N}$ loading and enhancing profitability and only in few instances there were "win-win" situations. According to our results, improvements in profitability and organic matter balance would require considerable changes in the farm configurations. The quantitative approach helped to assess vulnerability and resilience, to analyze and understand the magnitude of the impacts in the systems, and to simulate the responses of the farm under disturbances and practices to build resilience.

\subsection{Discussion}

The studied dairy farm systems were similar in their poor economic, environmental, and social performance. Therefore, our analysis was focused on exploring viable alternative pathways for the sustainable intensification of the dairy farms. In this context, it was decided to first evaluate if the current production activities of farmers in the region provided adequate scope for system performance improvement. Therefore, we did not explore alternative farm configurations that would imply radical changes in land use, such as moving from dairy to arable crops, fruits or other types of farming, or a diversification of the dairy products in the farms. The multi-objective optimization model FarmDESIGN was used to assess the yield gap in terms of milk production, to generate sets of alternative farm management strategies to enhance system performance based on selected economic and environmental criteria, and to assess farm resilience. These strategic changes should be accompanied by tactical changes, such as implementing better management of health and reproduction of the herd, on-farm production of concentrates, and improvement of forage production and 
management, prevention of pests and weeds, and reduction of mineral losses. These will be elaborated in more detail below.

\subsubsection{Economic performance of dairy systems}

The economic performance of dairy farms is affected by the quality of milk produced. Smallholders typically received US\$ $0.34 \mathrm{~kg}^{-1}$ of milk at the farm gate (Table 6.1). However, for milk with low bacterial counts and high protein and fat scores, Liconsa (a government agency to manufacture and sell dairy products) pays up to US\$ $0.38 \mathrm{~kg}^{-1}$ of milk in the study region (SAGARPA, 2014). Responding to the $70 \%$ rise in the international price of skim milk powder in the first half of 2007, Liconsa decided to install a milk gathering center (Centro de Acopio) at Marcos Castellanos. However, farmers meeting the milk sanitary standards were too few, and not enough milk could be gathered to afford the cost of transporting it to the nearest processing plant. The milk gathering center had to be closed. In other studies from Mexico low bacterial milk quality was found to be associated with poor udder cleaning and high mastitis incidence (Álvarez-Fuentes et al., 2012). Zadocks et al. (2004) found that milk from farms with cows infected with Staphylococcus spp. and Streptococcus

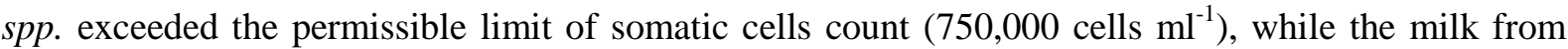
farms without infected cows had low somatic cell count. Mastitis incidence was rather high in the pilot farms (Chapter 3; Table 3.2), and it may be assumed that milk quality was low.

This high prevalence of mastitis in the herds could also have an additional negative economic impact in the dairy farms. The lack of sanitary programs to detect clinical and subclinical mastitis in the herds contributed to the poor economic performance of farms due to reduction in milk production in the udder quarter infected. The magnitude of this milk-yield loss is influenced by different factors including age, breed and type of the cows, stage of lactation, milk yield before infection, causal organism, extend of inflammation, and udder defense mechanisms (Seeger et al., 2003; Gröhn et al., 2004; Petrovsky et al., 2006). Petrovsky et al. (2006), found that clinical and subclinical mastitis can account for 70 to $80 \%$ of all mastitis losses, which implies a milk yield loss between 4.3 and 5.7\% over the entire lactation. A similar result was found by Seeger et al. (2003).

Table 6.1. Accounting and economic milk production costs and sale price of milk at farm gate in family-based (FB) and semi-specialized (SS) dairy farms in three levels of intensification: external (E), medium-intensive (M), and intensive (I) in Marcos Castellanos, Michoacán, Mexico, from July, 2009 to June, 2010.

\begin{tabular}{|c|c|c|c|c|c|c|c|c|}
\hline Variable & Units & FBE & FBM & FBI & SSE & SSM & SSI & Mean \\
\hline Direct milk production cost ${ }^{1}$ & US\$ $\mathrm{kg}^{-1}$ & 0.29 & 0.29 & 0.37 & 0.42 & 0.31 & 0.30 & 0.33 \\
\hline Total milk production cost ${ }^{2}$ & US\$ kg ${ }^{-1}$ & 0.50 & 0.44 & 0.47 & 0.47 & 0.38 & 0.43 & 0.45 \\
\hline Sales price of milk & US\$ kg-1 & 0.32 & 0.32 & 0.32 & 0.33 & 0.34 & 0.42 & 0.34 \\
\hline
\end{tabular}

${ }^{1}$ Only explicit costs (the payments made to others for service and inputs) per kg of milk produced.

${ }^{2}$ Based on both implicit costs (costs that do not imply a cash-expenditure) and explicit costs per kg of milk produced. 
The impacts related to the high use of concentrates and low milk productions were partially analyzed in Chapter 3, through the farm yield gap analysis. Feeding management was observed to be one of the most important practices impacting the economic performance of local dairy systems. Based on an economic analysis in which only the direct costs (the payments made to others for a service and inputs) were included, on average farmers earned US\$ 0.01 per $\mathrm{kg}$ of milk produced (Table 6.1). However, this analysis did not include the cost and/or value of family labor, which represented between 114 and 548 labor-days $\mathrm{y}^{-1}$, with highest values for family-based dairy farmers (Chapter 2; Table 2.4). When the indirect costs (costs that do not imply a cash-expenditure) and the direct costs were included in the milk production cost analysis, family-based farms lost on average US\$ 0.15 per $\mathrm{kg}$ of milk produced and semi-specialized only US\$ 0.06 (Table 6.1).

From Chapter 2, Table 2.5, it is estimated that feeding costs represented $60 \%$ of the economic milk production cost, and the cost of concentrates amounted to $66 \%$ of the total feeding costs. This large impact of costs of concentrates on milk production cost was due to the extensive use of external concentrates in the feed ration, with values which ranging between 37 and 56\%. Similar results were found by Espinoza-Ortega et al. (2005) studying smallholder dairy farms in Centeral Mexico, in which case feed cost amounted 49 to 55\% of the production costs. Considering that the price of concentrates closely traces milk prices paid to farmer (Figure 6.3, own data), it can be calculated that the cost of one $\mathrm{kg}$ of concentrates represented in recent years 76 to $91 \%$ of the local farm gate milk price. Therefore, it is necessary to design new feed management strategies, reducing the use of imported concentrates by more effective use of on-farm produced high quality feed stuffs. Such approach will greatly increase the resilience of local farming systems since farmers will be less affected by global fluctuations in market prices of key agronomic commodities such as maize and soybean.

The animal feed industry has attempted to reduce the cost of concentrates for dairy cattle by changing ingredients while sustaining quality. In a sample of 14 concentrates for lactating milk cows, it was found that maize grain is being replaced by sorghum (data not shown), which currently makes up for 22\% (between 8 and 40\%) of the total ingredients. The proportion of sorghum was found to be inversely related to the concentrate price $(r=-0.89)$. It was observed that the global price of coarse grains more than doubled since 2000 (Figure 6.4). This is partly related to increased use of maize to produce biofuel (ethanol) in U.S.A (McNew and Griffith, 2005; FIRA, 2008), the largest maize exporter worldwide. This reduced overall availability of maize resulted in increased demand for sorghum for animal feeding with the concurrent consequence of a rise in market prices (FIRA, 2008). It is expected that in the US the demand for maize for biofuels will continue to increase gradually until 2022 (Medina, 2012). This reduced availability, and competing claims on coarse grains and corresponding increases in global prices directly impacts the Mexican economy and dairy farmers in Michoacán. Mexico is the second largest maize and sorghum importer worldwide (FAO, 2014), with imports between 2000 and 2013 representing on average 36 to 46\% of the locally produced maize and 


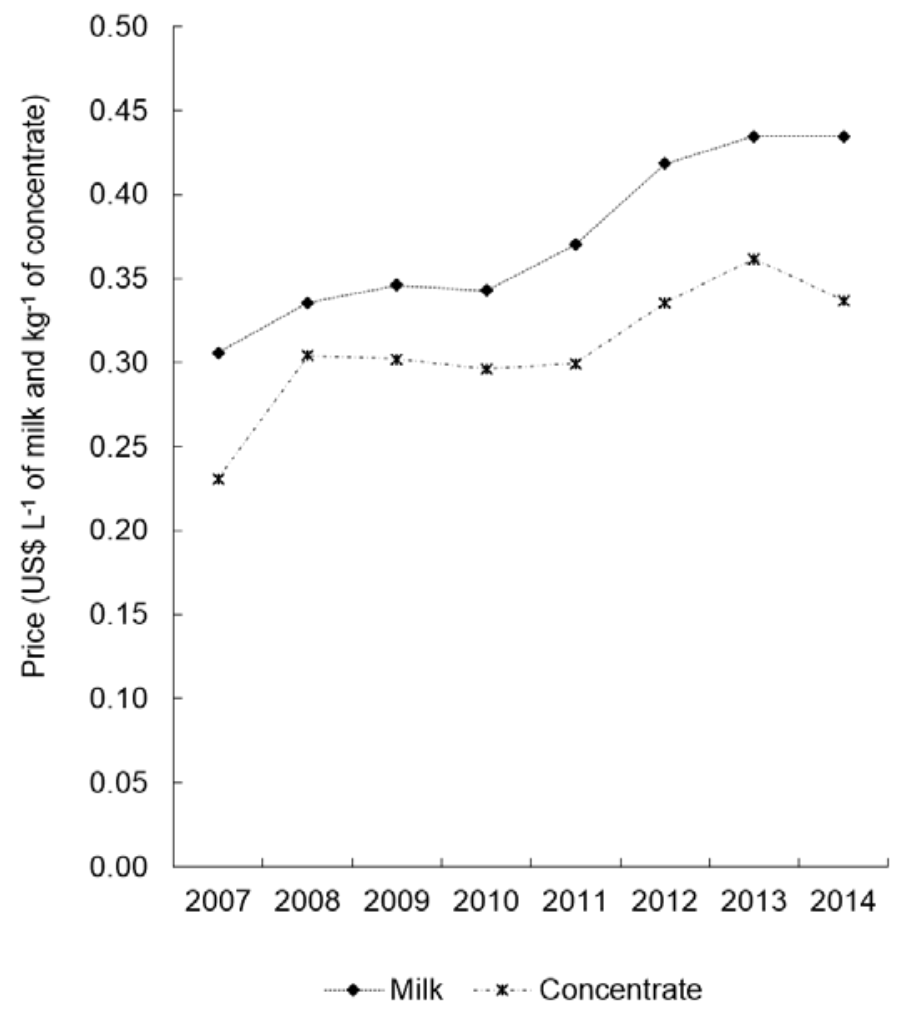

Figure 6.3. Milk price at farm gate and cost of concentrates for dairy cattle between 2007 and 2014 in Michoacán, Mexico.

Source: Own data.

sorghum (Figure 6.5). Imported grain is used for both human and animal consumption. On average, the animal feed industry uses $65 \%$ of coarse grains in concentrates, of which $61 \%$ is being imported (FIRA, 2008). Therefore, the price of concentrates is directly influenced by the international price of coarse grains, and based on a continuous increase in global demand it is likely that prices will keep rising. This implies the need to look for alternatives to feed animals and to improve farm performance. Such alternatives include for instance better management of grazing on rangelands to increase productivity, and establishment of improved pastures to overcome periods of low rangeland productivity during the dry season. Additional training may be needed since current forage yields were below those expected for Rhodes grass (Chloris gayana) and annual ryegrass (Lolium multiflorum) (Chapter 3; Table 3.3). For the dry season, farmers may develop alternatives to the current dry ground maize forage by preserving forage maize as silage, and by establishing a second forage crop such as barley and oat, and growing it on residual soil moisture. 


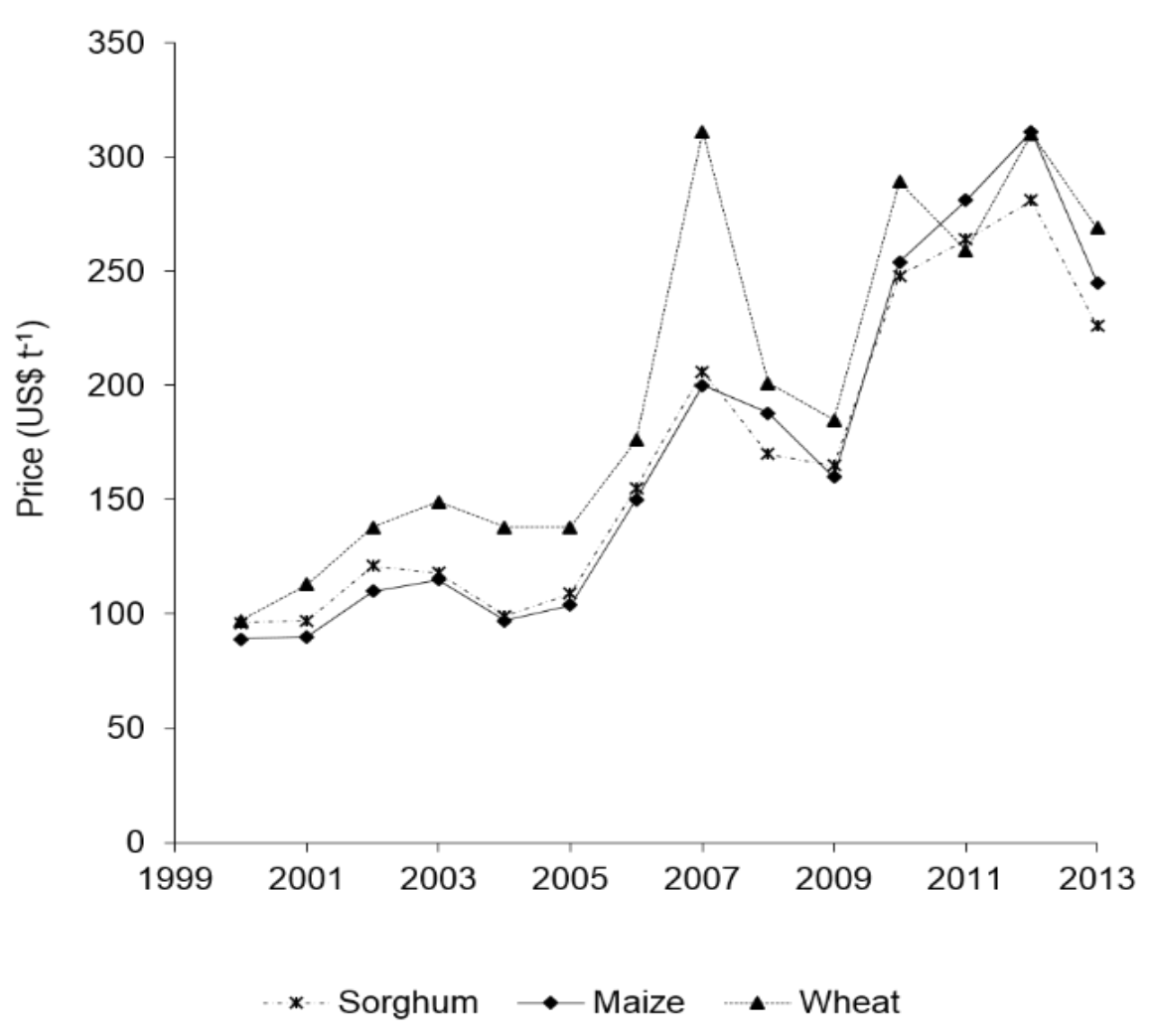

Figure 6.4. Global price trends for maize and sorghum from 2000 to 2013.

Source: FAO, 2000, 2005, 2014.
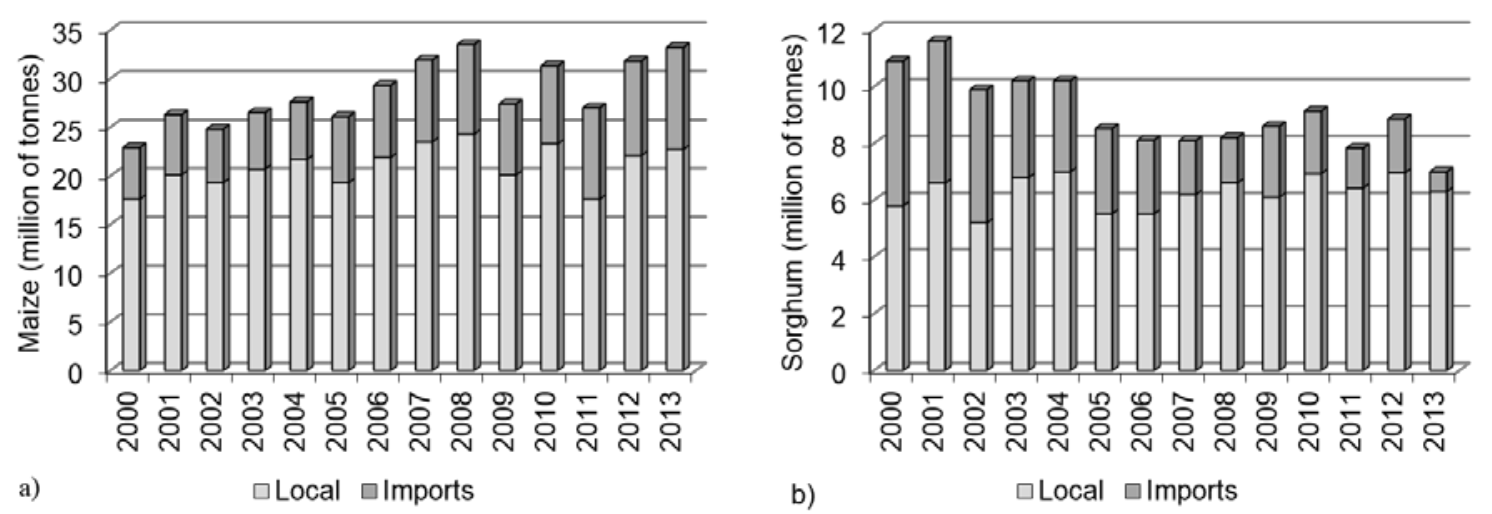

Figure 6.5. Share of locally produced vs imported maize (a) and sorghum (b) in annual total grain use in Mexico between 2000 and 2013.

Source: SHCP, 2014; FAO, 2014.

\subsubsection{Environmental performance of dairy systems}

The environmental analysis focused on N, P, K and soil organic matter balances in dairy systems. The results of nutrient balances showed that $N, P$ and $K$ surpluses were $75 \pm 16,15 \pm 6$, and $19 \pm 6 \mathrm{~kg} \mathrm{ha}^{-1}$, respectively (Chapter 3; section 3.3.5). This accumulation of nutrients points to inefficiencies, potential losses and/or environmental emissions (Koelsch, 2005; Powell et al., 2010). Moreover, all 
dairy systems performed poorly in terms of soil organic matter (SOM) declining over time, and none of the solutions pursued during exploration of alternatives, showed promise in terms of augmenting SOM (Chapter 4; sections 4.3.2 and 4.3.3; chapter 5; section 5.3.2). The accumulation of nutrients and the depletion of SOM appear to be closely linked to poor manure management. Most dairy farms did not collect nor effectively recycle dairy manure within their production system. The areas allocated to crop production appear to be most affected since maize forage is completely removed without any return of organic matter as cows typically do not graze directly on maize fields. Moreover, due to repeated tillage these areas are also more prone to increased mineralization of organic matter and soil erosion on sloping lands. For grassland fields one of the key issues is that due to poor rotational grazing management manure tends to accumulate in small areas where it leads to high gaseous emissions, soil degradation, and nutrient loading of surface waters due to runoff (Van der Molen et al., 1998). To mitigate these impacts and to increase the efficiency of nutrients in the farm system, farmers can improve the distribution of nutrients across fields by implementing practices such as grazing for short periods in small areas. These alternatives help to spread more uniformly the nutrients contained in the manure over the different areas of the farms.

The use of pesticides (insecticides, nematicides and fungicides) and herbicides also has clear implications on the environment and human health. Agriculture is the main user of pesticides and herbicides accounting for $85 \%$ of the total use (Wilson and Tisdell, 2001). Products are typically used to control and prevent pests, fungi and weeds in agriculture, and mainly parasites in livestock. In terms of the environment, contamination of water, soil, and air negatively impact to wildlife, soil biological activities, fishery, natural habitat, and can kill beneficial natural predators and other biological control agents (Wilson and Tisdell, 2001; Pimentel, 2005; Drogui and Lafrance, 2012). Moreover, in domestic animals, insecticides and herbicides are one of the main causes of poisoning while also posing threats to human health due to acute and chronic toxicity effects including cancer and poisoning (Pimentel, 2005; Drogui and Lafrance, 2012). In the crop subsystem of dairy-based systems, the average pesticides and herbicides use was $3.8 \mathrm{~kg} \mathrm{ha}^{-1}$ of active ingredient (AI), of which herbicides accounted for $62 \%$ (Table 6.2). However, there were distinct differences between farms, the extremes being FBE which only applied herbicides at $1.2 \mathrm{~kg} \mathrm{AI} \mathrm{ha}^{-1}$, compared to 2.9 and $3.5 \mathrm{~kg} \mathrm{AI} \mathrm{ha}^{-1}$ pesticides and herbicides being used in SSE, respectively (Table 6.2). Pimentel (2005) mentioned that in North America approximately $3 \mathrm{~kg} \mathrm{AI} \mathrm{ha-1} \mathrm{y}^{-1}$ of pesticides is applied in croplands, which is considered to have negative consequences on both environmental quality and human health. Considering the low productivity of the local dairy systems, the use of agrochemicals seems disproportionally high.

We did not evaluate the effect of the use of the pesticides and herbicides on the quality of milk; however, Salas et al. (2003) analyzed residues of organophosphorus pesticides in four brands of commercial milk, and found that $39.6 \%$ of the samples contained detectable levels of residues and 
Table 6.2. Use of insecticides and pesticides ( $\mathrm{kg} \mathrm{AI} \mathrm{ha}^{-1}$ of cropland) on family-based (FB) and semi-specialized (SS) dairy farms, at three levels of intensification: extensive (E), medium-intensive (M), and intensive (I) in Marcos Castellanos, Michoacán, Mexico, from July, 2009 to June, 2010.

\begin{tabular}{llllllll}
\hline Concept & FBE & FBM & FBI & SSE & SSM & SSI & Mean \\
\hline Pesticides $^{\S}$ & 0.00 & 0.8 & 2.8 & 2.9 & 1.4 & 0.9 & 1.5 \\
Herbicides & 1.2 & 3.5 & 2.2 & 3.5 & 1.6 & 2.2 & 2.4 \\
Total active ingredient & 1.2 & 4.4 & 5.0 & 6.4 & 3.0 & 3.1 & 3.8 \\
\end{tabular}

$\S$ Includes insecticides and nematicides.

8.3\% exceeded the established maximum limits of residues. Chlorpyrifos and Phorate were two of the main residues found in the samples, and these are mainly used in forage crops. Therefore, in terms of human health, environmental impacts, and production costs, it will be relevant to further limit the use of pesticides and herbicides in Mexican dairy-based farming systems. Attention for methods of and need for pesticide use may be included in training programs aimed at improving technical skills of farmers, which could include also training on enhanced use of internal resources on farms, and in the prevention instead of control of pests and weeds.

\subsubsection{Social performance of dairy systems}

Due to increased globalization, Mexican dairy farmers compete with farmers from regions with more favorable ecological conditions or that benefit from subsidies for milk production (Ángeles-Montiel et al., 2004). In both cases, this results in unfair competition, and it reduces revenues of local smallholder dairy farmers (Lara-Covarrubias et al., 2003; Espinoza-Ortega et al., 2005; Brambila-Paz et al., 2013). Ángeles-Montiel et al. (2004) concluded that milk imports mainly benefit consumers, while the relatively low-priced import milk reduces the milk price in the national market. The analysis is still valid today. This may result in increased marginalization of the dairy sector and does not induce farmers to invest in more sustainable production practices.

In addition to low milk prices, the lack of technological training on some farm management practices and marketing, poor milk quality and lack of organization among dairy farmers are other factors that affect productivity and economic efficiency of dairy farms (Aguilar and López, 2006). Future policies therefore should aim to strengthen the organization of farmers, promote local dairy cooperation and provide better access to appropriate technologies including adding value techniques, direct marketing strategies while reducing environmental impacts (SAGARPA, 2008). These technologies must consider to improve the use of the internal resources while reducing the external dependency, training in forage production and management, both for grazing and conservation, in herd management, in milking routing, and in the prevention and control of pests and weeds. 
The current globalization of increasingly volatile markets plays an important role in governing the profitability and performance of the agents involved in the dairy sector with smallholder farmers being the most affected. Brambila-Paz et al. (2013) reported that in 2009 the marketing margin distribution for milk in Mexico at national level was 0.47 for retailers, 0.16 for processors, and 0.37 for producers, and considered that these proportions should be $0.25,0.20$ and 0.55 to reflect the costs. Therefore, the minimum price paid to farmers should be US\$ $0.48 \mathrm{~L}^{-1}$ (Brambila-Paz et al., 2013) compared to the US\$ 0.34 actually paid. Increased milk prices could help dairy farmers to invest in the production capacity and efficiency of their farms, thereby increase productivity, milk quality while the formation of cooperatives would increase their negotiation power in the market. In this manner smallholders and their families could sustain their operations without adversely impacting the milk price and cost of living of consumers. However, this will require extensive reforms and regulations and institutional support for farmers and processors to facilitate a fairer sharing of profits across the different stakeholder groups within the product system.

Considering that commodities such as milk are important for social stability, and given the large number of people that are directly or indirectly engaged in the dairy sector, it is relevant to establish effective policies and technological support measures to enhance productivity and economic efficiency. Alternatively, given the current economic performance of dairy farming, where small famers do not earn enough to cover the primary needs of an average family (Chapter 2; section 3.4), the high rate of migration from rural to urban regions is likely to continue.

\subsection{Research methodology}

This thesis describes a number of methodologically new elements, in addition to the characterization of the farming systems management, considering their technical, social, economic, and environmental components. The thesis represents one of the few quantitative assessments of Mexican dairy farming systems in the scientific literature. Only Castelán-Ortega et al. (2003) and Val-Arreola et al. (2004, 2006) used computational tools to simulate and explore alternatives for Mexican dairy farming systems. The thesis introduces a novel procedure to analyze farm yield gaps, which may be seen as the complement of the dominant attention for field-level yield gap analysis. In this thesis we constructed the reference farm based on feed self-reliance in terms of two nutritional components, i.e. metabolizable energy and crude protein. Other nutritional elements can be added if needed and where information is available, such as digestibility or mineral requirements. Another novel methodological element we introduced in this thesis is a quantitative approach to operationalize vulnerability and resilience of agro-ecosystems by using an explorative multi-objective model. The approach maps the rather conceptual notions of vulnerability and resilience in terms of the multiple objectives that characterize farming system strategies, and shows the scope for maneuver under current and extended 
technology sets. Our quantitative approach shows how the relations between the components affect social, economic, and environmental sustainability domains at farm system level in a visual way.

At the beginning of the study two workshops were held involving groups of local dairy farmers and a multidisciplinary team of researchers to support the conceptualization and implementation of the activities. The workshops firstly helped to establish and enhance the interaction between different stakeholder groups involved in the project. Secondly, they resulted in improved understanding by the researchers of the local dairy sector and its problems. It allowed the research team to become more aware of the main concerns of local farmers, and to structure viable solutions. Thirdly, the research team could identify leaders that later became key informants and agents of change, helping to support the ongoing field work and exploration of viable alternatives via a co-innovation process. Finally, the group of farmers was well aware of the overall project objectives and scope and in this manner misconceptions could be overcome.

Considering that one objective of this work was to assess the environmental, social and economic performance of current smallholder dairy systems within the study region, having a multidisciplinary team was essential for successful project implementation. This team helped to select appropriate system performance variables and also provided expertise during structuring of the database. Moreover, the close collaboration with pilot farmers allowed us to keep and share critical information, which at the end became the more important asset for the overall analysis of the existing farming systems. The diverse and detailed information gathered with the help of farmers allowed us to characterize and compare the performance of dairy systems from different stakeholder perspectives.

As a part of this study, a total of three experiments were established. The first one aimed to identify promising grass species for the establishment of improved pastures. The second study focused on assessment of soil erosion under maize and grassland. The third study measured soil chemical and physical variables in different cropping systems. The first experiment failed due to poor crop establishment; however, the other experiments provided important information that was used during subsequent model-based explorations. Moreover, results from these experiments may also be useful in the design of alternative technologies and management practices, which may enhance resource use efficiency, and thereby both potential production and profitability of the prevailing dairy systems.

\subsection{Challenges for on-farm implementation}

In this thesis alternatives to improve dairy farm sustainability were explored using a static, exploratory, and multi-objective optimization model that quantifies farm production, economic and environmental performance on an annual basis (Groot et al., 2012). The model was used to generate alternative farm configurations that represent an improvement of current systems. The outcomes from the simulations of plausible alternatives to improve economic, social and environmental performance 
of dairy farms showed wide windows of opportunities for improvement, with pronounced differences among different farming types and intensification gradients. These alternatives implied re-allocation of current farm endowments. During the optimization process the objectives and priorities of farmers were not explicitly included, nor were the full implications of these changes evaluated using on-farm pilot trials.

The next step and a major challenge would be to implement and evaluate these alternatives on real farms. This must be done in a participatory manner, where researchers, farmers, technical advisors, and policy makers participate to define the best and most viable alternatives based on objectives that address the interest of all stakeholder groups involved. Working in this way, the participative process may improve the relevance and realism of the analysis of the current situation while also being more effective in identifying and characterizing emerging problems and structuring appropriate solutions. This type of process will generate unique opportunities for exchanging knowledge and transforming technological innovations. Moreover, it will facilitate the structuring of relevant experiments to address knowledge gaps, and formulate plans of action by allowing all players to directly contribute and benefit from the analysis and design process (Norman, 2002). These aspects are needed in order move beyond the third (exploration of scenarios for alternatives of improvement) system development step of the DEED cycle. The process to scale-out our results to regions beyond Marcos Castellanos needs to take into account local specificities and similarities among regions (Norman, 2002). More case study approaches may be needed before arriving at insights on patterns of farm systems and their (un)sustainability across regions.

During the exploration process, we found some options in terms of alternative management techniques and/or practices that were not included due to inherent limitations of the model. As stated before, the alternatives evaluated during explorations were mainly targeted at re-allocation of existing farm resources, which is important since such changes do not imply additional investment in terms of technology or infrastructure to improve the performance. However, this also limits the scope for improvement as there may be other practices that can be readily implemented that may result in greater socio-economic and ecological benefits with minimal investment (Table 6.3). These may include improved detection of cows in heat, implementing better milk routing, improved prevention and treatment of mastitis, transforming milk into dairy products, feeding animals according to age and production classes, improving forage production and its management, and use of better silage techniques. For most of these interventions training and capacity building is needed, but they require relatively low investment and return per investment may be high while economic and social impacts may be appreciable.

Working with smallholder dairy farms, Bayemi et al. (2009) reported that changes such as using artificial insemination, improving feed supplementation, on-farm processing of milk, and securing better veterinary services resulted in reduced farm expenditures and increased farm income. In terms 
Table 6.3. Alternative practices to improve dairy farm systems, and their implication, not included in the exploration process.

\begin{tabular}{|c|c|c|}
\hline Practice & Direct improvement & Method \\
\hline Heats detection & Calving interval and milk production. & $\begin{array}{l}\text { Training farmers to detect cows in heat and } \\
\text { to implement reproductive records. }\end{array}$ \\
\hline Milking routine & $\begin{array}{l}\text { Milk quality and reduction of udder } \\
\text { infections. }\end{array}$ & $\begin{array}{l}\text { To teach farmers appropriate milking } \\
\text { routines, investment in liquids to wash the } \\
\text { milking machines, and, in some cases, to buy } \\
\text { a milking machine. }\end{array}$ \\
\hline Mastitis test & Milking production and milk quality. & $\begin{array}{l}\text { Training farmers to detect the infection, to } \\
\text { improve the milking routines, and to buy the } \\
\text { equipment for a quick test (normally cheap). }\end{array}$ \\
\hline Feeding management & Feeding costs and production. & $\begin{array}{l}\text { To teach farmers about feeding strategies } \\
\text { and management. This includes forage } \\
\text { production, grazing management, and } \\
\text { processing of concentrates. }\end{array}$ \\
\hline Dairy products & $\begin{array}{l}\text { Income diversification and } \\
\text { profitability of the systems. }\end{array}$ & $\begin{array}{l}\text { To teach farmers to transform milk into } \\
\text { different dairy products, and implement } \\
\text { farmers organization to compete in the } \\
\text { market. }\end{array}$ \\
\hline Forage conservation & $\begin{array}{l}\text { Feed availability and production } \\
\text { costs. }\end{array}$ & $\begin{array}{l}\text { Training to improve the techniques to } \\
\text { preserve the forage produced in the farm. }\end{array}$ \\
\hline Manure use & $\begin{array}{l}\text { Reduction of forage production costs } \\
\text { and of environmental impacts; } \\
\text { improvement of organic matter } \\
\text { balance. }\end{array}$ & $\begin{array}{l}\text { Training about manure management and } \\
\text { manuring. }\end{array}$ \\
\hline Use of records & Administrative control. & $\begin{array}{l}\text { Training farmers to record information to be } \\
\text { analyzed for decision making. }\end{array}$ \\
\hline
\end{tabular}

of environmentally quality aspects, there are still many challenges. These include improving water use efficiency, reducing contamination of both surface and groundwater resources, soil degradation and erosion, greenhouse gas emissions, and enhancing biodiversity. Moreover, it is argued that by enhancing farm profitability farmers may have more leeway to also improve the environmental performance of their system.

This thesis has made a contribution to sustainable intensification of smallholder dairy systems by analyzing farms in Michoacán. Appling different statistical and modelling tools, it was possible to characterize the types of systems, to identify room for improvement, and to explore alternatives for change considering economic, social, and environmental domains. This thesis showed the analytical results, but implementing actual changes on the ground requires on-farm elaboration. In addition to 
farm-specific changes, such activities should carefully consider farmer organization and other institutional settings and their support in strengthening sustainable intensification of smallholder dairy systems. Scientists can play a role in such processes through transfer of knowledge, monitoring and interpreting changes, and by widening the scope of alternatives. Such multidisciplinary scientific involvement in farm development is much needed, and will require both researchers and farmers to learn how to benefit optimally from each other's knowledge.

\subsection{References}

Álvarez-Fuentes, G., Herrera-Haro, J.G., Alonso-Bastida, G., and Barreras-Serrano, A., 2012. Calidad de la leche cruda en unidades de producción familiar del sur de Ciudad de México. Arch Med Vet 44: 237 - 242.

Amendola, R.D., 2002. A dairy system based on forages and grazing in temperate Mexico. Ph.D. dissertation. Wageningen University, The Netherlands.

Ángeles-Montiel, R., Mora-Flores, J. S., Martínez-Damián, M.A., and García-Mata, R., 2004. Efecto de las importaciones de leche en el mercado nacional del producto. Agrociencia 38: 555-564.

Bayemi, P.H., Webb, E.C., Ndambi, A., Ntam, F., and Chinda, V., 2009. Impact of management interventions on smallholder dairy farms of the western highlands of Cameroon. Trop Anim Health Prod 41: 907 - 912.

Brambila-Paz, J.J., Mora-Flores, S., Rojas-Rojas, M., and Pérez-Cerecedo, V., 2013. El precio mínimo al productor primario de leche para reducir las importaciones de lácteos en México. Agrociencia 47: 511-522.

Castelán-Ortega, O.A., Fawcett, R.H., Arriaga J., C., and Herrero, M., 2003. A decision support system for smallholder campesino maize-cattle production systems of the Toluca Valley in central Mexico. Part II - Emulating the farming system. Agricultural Systems. 75: 23 - 46.

Cervantes, F., and Cesín, A., 2007. La pequeña lechería rural o urbana en México y su papel en el amortiguamiento de la pobreza. Revista Unellez de Ciencia y Tecnología 25: 72-85.

Drogui, P., and Lafrance, P., 2012. Pesticides and sustainable agriculture: In Farming for food and water security, sustainable agriculture. DOI 10.1007/978-94-007-4500-1_2.

Espinoza-Ortega, A., Álvarez-Macías, A., Del Valle, M. del C., and Chauvete, M., 2005. Small-holder (campesino) milk production systems in the highlands of Mexico. Tec Pecu Mex 43(1): 39 56.

FAO, 2000. Food outlook: Global Information and early warning on food and agriculture. No. 5. In: http://www.fao.org/giews/English/fo/index.htm. Retrieved: September, 2014.

FAO, 2005. Food outlook: Global Information and early warning on food and agriculture. No. 4. In: http://www.fao.org/giews/English/fo/index.htm. Retrieved: September, 2014. 
FAO, 2012. Experiencias exitosas de integración asociativa de productores lechero: tres estudios de casos en Nicaragua, Ecuador y Paraguay. Oficina Regional de la FAO para América Latina y el Caribe, División de Producción de Sanidad Animal. 57 p.

FAO, 2014. Food outlook: Biannual report on global food market. In: http://www.fao.org/giews/English/fo/index.htm. Retrieved: September, 2014.

FAOSTAT, 2012. FAO statistical databases. In: http://faostat.fao.org/site/452/default.aspx. Retrieved: January, 2012.

FIRA (Fideicomisos Instituidos en Relación con la Agricultura), 2008. Situación actual y perspectivas de los granos en México. In http://www.fira.gob.mx/InfEspDtoXML/TemasUsuario.jsp. Retrieved: September, 2014.

Groot, J.C.J., Oomen, G.J.M., and Rossing, W.A.H., 2012. Multi-objective optimization and design of farming systems. Agricultural Systems 110, 63-77.

Hazell, P., and Wood, S., 2008. Drivers of change in global agriculture. Phil. Trans. R. Soc. B 363: $495-515$.

Koelsch, R.K., 2005. Evaluating livestock system environmental performance with whole-farm nutrient balance. J. Environ. Qual. 34: 149 - 155.

Lara-Covarrubias, D., Mora-Flores, J.S., Martínez-Damián, M.A., García-Delgado, G., OmañaSilvestre, J.M., and Gallegos-Sánchez, J., 2003. Competitividad y ventajas comparativas de los sistemas de producción de leche en el Estado de Jalisco, México. Agrociencia 37, 85-94.

Naylor, R., Steinfeld, H., Falcon, W., Galloway, J., Smil, V., Bradford, E., Alder, J., and Mooney, H., 2005. Losing the links between livestock and land. Science 310: 1621 - 1622.

Norman, D. W., 2002. The farming systems approach: A historical perspective. In: Symposium of the International Farming Systems, Paraná state of Brazil.

McNew, K and Griffith, D., 2005. Measuring the impact of ethanol plants on local grain prices. Review of Agricultural Economics 27: 164-180.

Medina R., S., 2012. El etanol en Estados Unidos y su efecto negativo en México. Comercio Exterior. In: http://revistas.bancomext.gob.mx/rce/magazines/143/2/El_etanol_en_EEUU.pdf. Retrieved: September, 2014.

Pimentel, D., 2005. Environmental and economic costs of the application of pesticides primarly in the United States. Environment, Development and Sustainabilit 7: 229 - 252.

Powell, J.M., Gourley, C.J.P., Rotz, C, A., and Weaver, D.M., 2010. Nitrogen use efficiency: A potential performance indicator and policy tool for dairy farms. Environmental Science \& Policy 13: 217-228.

Salas, J.H., González, M.M., Noa, M., Pérez, N.A., Díaz, G., Gutiérrez, R., Zazueta, H., and Osuna, I., 2003. Organophosphorus pesticides residues in Mexican commercial pasteurized milk. J. Agric. Food Chem. 51: 4468 - 4471. 
SAGARPA, 2008. Tratado de Libre Comercio de América del Norte: Sector agroalimentario. In: http:// oiedrus-durango.gob.mx/TLC.pdf. Retrieved: April, 2013.

SAGARPA, 2014. Boletín de Leche: Enero-Marzo de 2014. In: http://www.siap.gob.mx/wpcontent/uploads/2013/BoletinLeche/Bolet_LecheEne-Mar_2014.pdf. Retrieved: September, 2014.

Salas, J, H., González, M. M., Noa, M., Pérez, N. A., Díaz, G., Gutiérrez, R., Zazueta, H., and Osuna, I., 2003. Organophosphorus pesticides residues in Mexican comercial pasteurized milk. J. Agric. Food chem. 51: 4468 - 4471.

SE (Secretaría de Economía), 2012. Análisis del sector lácteo en México. Secretaría de Economía. In: http://www.economia.gob.mx/files/comunidad_negocios/industria_comercio/informacionSec torial/analisis_sector_lacteo.pdf. Retrieved: November, 2012.

SEGOB (Secretaría de Gobernación), 2010. Encuesta sobre migración en la frontera norte de México, 2008. Instituto Nacional de Migración. México, D.F. 318 p.

Tittonell, P., 2008. Msimu wa Kupanda: Targeting resources within diverse, heterogeneous and dynamic farming systems of Esast Africa. Unpublished Ph.D. dissertation. Wageningen University, The Netherlands. In: http://edepot.wur.nl/121949. Retrieved: February, 2013.

Tittonell, P., 2014. Livelihood strategies, resilience and transformability in African agroecosystems. Agricultural Systems 126:3-14.

Thornton, P.K., 2010. Livestock production: recent trends, future prospect. Phil. Trans. R. Soc. B 365: $2853-2867$.

Val-Arreola, D., Kebreab, E., Mills, J.A.N., Wiggins, S.L., and France, J., 2004. Forage production and nutrient availability in small-scale dairy systems in central Mexico using linear programming and partial budgeting. Nutrient Cycling in Agroecosystems 69: 191 - 201.

Val-Arreola, D., Kebreab, E., and France, J., 2006. Modeling small-scale dairy farms in central Mexico using multi-criteria programming. J. Dairy Sci. 89: 1662 - 1672.

Van der Molen, D.T., Breeuwsman, A., and Boers, P.C.M., 1998. Agricultural nutrient losses to surface water in the Netherlands: Impact, strategies, and perspectives. J. Environ. Qual. 27: 4 -11 .

Vishwanath, R., 2003. Artificial insemination: the state of the art. Theriogenology 59: $571-584$.

Wilson, C., and Tisdell, C., 2001. Why farmers continue to use pesticides despite environmental, health and sustainability costs. Ecological Economics 39: 449 - 462.

World Bank, 2008. World development report 2008: Agriculture for development. The World Bank. Washington, D.C.. 365 p.

Zadoks, R.N., González, R.N., Boor, K.J., and Schukken, Y.M., 2004. Mastitis-causing streptococci are important contributors to bacterial counts in raw bulk tank milk. Journal of Food Protection 67(12): $2644-2650$. 
Zarazúa-Escobar, J. A., Almaguer-Vargas, G., and Ocampo-Ledesma, J. G., 2011. El programa de apoyos directos al campo (Procampo) y su impacto sobre la gestión del conocimiento productivo y comercial de la agricultura del Estado de México. Agricultura, Sociedad y Desarrollo 8 (1): 89 - 105. 

Summary 



\section{Summary}

At global level, population growth along with changes in life style and consumption patterns in countries such as China, India and Brazil are projected to have a significant impact on agricultural production systems. Annual food consumption per capita is expected to increase by $9 \%$. Therefore, agricultural systems are challenged to produce enough to feed the population. There are three possible solutions to meet the projected increase in food demand. The first solution is to reduce food losses and waste, which currently cause around one-third of the edible food products to be lost or wasted. The second solution is to increase the area dedicated to livestock production and arable farming. And, the third solution is to improve farm systems resource use efficiencies and thereby also productivity, this in order to produce "more" with "less". In the context of farm systems, research can play an important role in system design and developing new and more efficient technologies to produce food to feed the population without compromising production capacity or natural resources.

Although smallholder farms produce a large share of the world's food supply and their production systems could potentially be diverse and sustainable, market and policy developments force them to intensify their production in order to compete with larger specialized farms. This often leads to an 'intensification-trap': in order to increase productivity small farmers intensify their production systems by increasing livestock density and inputs, but inadequate management results in larger nutrient surpluses or losses, farm resource degradation and strong dependence on external feeds and fertilizers. Preliminary work also found this situation in the municipality of Marcos Castellanos, Michoacán, Mexico, where agricultural livelihoods revolve around dairy farming.

The overall aims of this thesis were to assess the environmental, social and economic performance of smallholder dairy farming in Marcos Castellanos, Michoacán, Mexico, and to use this assessment to explore alternatives to enhance farm sustainability. In this manner the thesis aims to support decision making by farmers and technicians, and to provide information that can aid local governments to establish policies that are effective at improving farmers' livelihoods. The specific objectives were:

- Identify to which extent results of farm surveys that measure primarily scale of production can inform on-farm interventions aimed at improving farm performance (Chapter 2);

- Analyze how management strategies for different dairy farming systems affect nutrient and soil organic matter balances, nutrient use efficiency, economic efficiency and labor productivity (Chapter 3);

- Explore management alternatives that can enhance dairy farming systems performance, while improving resource use efficiency and reducing negative environmental impacts (Chapter 4); and

- Analyze vulnerability and resilience of these dairy farming systems in the context of disturbances in the availability of internal and external inputs (Chapter 5). 
To reach these objectives, a survey was conducted among 97 dairy farmers (14.6\% of total population), randomly selected in the study region (Chapter 2). The survey included questions on biophysical and socio-economic resources, and on farm management practices. The survey demonstrated that $69 \%$ of the farms owned less than 25 ha of land, and $56 \%$ had less than 25 ha of grazing land. Farmers rented on average $50 \%$ of the land, and $51 \%$ of farms had less than 40 livestock units (LU). Hired labour represented $20 \%$ of the total labour input, mainly hired for animal management and for forage maize harvesting and processing. Milk production was the main source of income for the farms. The development of a farm typology enabled the distinction of four farm types, including two types of family-based (FB) and two types of semi-specialized (SS) systems based on land area, livestock units, amount of hired labour, and infrastructure and equipment. Indicators for animal health management and feeding strategies were uniform across the 4 types. The farm types matched the distinction of family-based and semi-intensive farm types used in Mexico. The survey was complemented with detailed analyses of costs, revenues and productivity on 6 farms over the course of one year (Chapter 2). Three were family-based, the other three were semi-intensive farm types. The six farms were representative of extensive (FBE and SSE, $<0.8 \mathrm{LU} \mathrm{ha}^{-1}$ ), medium-intensive (FBM and SSM, between 0.8 and 1.2 LU ha ${ }^{-1}$ ), and intensive (FBI and SSI, >1.2 LU ha ${ }^{-1}$ ) farming systems. The detailed analyses of the individual farms belonging to the different types revealed differences in resource use strategies reflected in differences in animal productivity, labour productivity and return to labour. Differences in animal productivity and labour productivity were explained by stocking rate, albeit in different ways. Return to labour was strongly related to cost of feed. Profitability was negative for all farms and was on most farms related to high external feedstuff costs, which constituted 59-89\% of the feed cost of the animal ration. The results indicate that in addition to variables reflecting resource endowment or scale of production, typologies that aim to inform on-farm interventions need to consider farm characteristics that reflect intensity of production. Which variables should be selected will need to be determined in a preliminary assessment.

The database of the six farms was used to analyze resource use efficiencies (Chapter 3). Whole-farm yield gaps were quantified by comparing current farms to virtual reference farms that had the same farm surface area but improved farm management. Productivity of reference farms was calculated by assuming best crop production practices (as observed within the set of case study farms) and improved herd management. Milk production was generally low and variable (2.2-4.3 Mg milk cow ${ }^{-1}$ lactaction $^{-1}$, and 0.6-5.8 $\mathrm{Mg} \mathrm{ha}^{-1}$ ) due to high incidence of mastitis, a large fraction of non-productive animals in the herd and inefficient reproduction management. During the dry season, grazing areas provided insufficient metabolizable energy, and milk production was sustained through increased use of concentrates (from $310 \mathrm{~g} \mathrm{~kg}^{-1} \mathrm{DMI}$ in rainy season to $454 \mathrm{~g} \mathrm{~kg}^{-1} \mathrm{DMI}^{-1}$ in dry season of the herd) and conserved forage. All farms had positive nitrogen, phosphorus and potassium balances, averaging $75 \pm 16,15 \pm 6$, and $19 \pm 6 \mathrm{~kg} \mathrm{ha}^{-1}$, respectively. Nutrients in animal excreta were mostly not recycled on 
the farms but lost to the environment, and nutrient surpluses increased with livestock density. The reference farms exhibited an attainable milk yield of $2.7 \mathrm{Mg} \mathrm{ha}^{-1}$ on the basis of full feed self-supply, and 4.2 $\mathrm{Mg} \mathrm{ha}^{-1}$ when the crude protein limitation in the ration was lifted. Compared to the reference farm actual milk yields were on average $78.4 \%$ lower on FB farms and 57.9\% lower on SS farms. The underlying causes of the farm yield gap differed between farms and were due to sub-optimal areas of forage maize, low forage and forage maize productivity and deficient herd management.

With the detailed information of the selected representative dairy farms, we explored alternative intensification pathways for each farm system, using a static exploratory model (Chapter 4). The exploration focused on possible pathways for sustainable farm intensification considering the current production activities of farmers in the region as starting point. We did not explore alternative farm configurations that would imply radical changes in land use. Three groups of alternative farm configurations were identified, using different weights for each of the objectives (profitability, feed costs, labor needs, nitrogen and organic matter balances). The groups were labelled as 'economic' for alternatives that prioritized profitability, 'environmental' for alternatives that prioritized OM balance, and 'integrated' for alternatives that combined minimization of labor used (social objective), with reducing $\mathrm{N}$ balance (environmental objective) and feeding costs (economic objective). The 'economic' group of alternatives had the highest percentage of lactating cows in the herd, and four out of five farms sold a large amount of on-farm produced forage. The 'environmental' group of alternatives was characterized by having the largest milk production per hectare, and greatest stocking rates, $\mathrm{N}$ surpluses, ration costs, and labor needs. The 'integrated' group included those alternatives that reduced ration costs and dependence on external inputs, and typically included more forage and grazing in the ration. In general, 'integrated' alternatives were most predominant in FBE, FBI, SSE and SSI while economic ones were less abundant in FBE, SSE, SSM and SSI. Our analyses revealed that to improve the economic performance of the dairy farms, farmers needed to diversify their outputs combining sales of milk and maize forage, and to improve their herd structure with higher percentages of lactating cows. To enhance environmental performance, further intensification was required to accumulate more soil organic matter, which was associated with greater stocking rate, dry matter intake, and external dependency on feedstuffs. 'Integrated' alternatives had a balance among the social, economic and environmental domains, with less labor needs (implying more time for other activities or less hired labor), lower ration costs, higher use of own resources, and reducing $\mathrm{N}$ surplus. The major differences in productivity between current farms and model results were found in variables related to stocking rate and cropping areas, as well as concentrate inputs to fulfill nutritional requirements of the herd. Semi-specialized dairy farms had broader windows of opportunity for improvement than family-based systems.

In Chapter 5 we presented a novel quantitative approach to analyze and assess the agro-ecosystems attributes vulnerability, buffer capacity and adaptive capacity. We related these attributes to solution 
spaces that represent the possible changes in terms of selected performance indicators as affected by adjustments in components, processes and management of the systems. We expressed the vulnerability of the system as the Euclidian distance of performance indicators between original and disturbed systems. The buffer capacity was derived from the size of the solution space that could be obtained after reconfiguration of farm components (crops, animals, fertilizers, etc.) that were present on the original farm, whereas the assessment of adaptive capacity was derived in a similar way but after allowing innovation by introducing new components to the farm. As an illustration, we analyzed the reduction in forage maize production due to pest attack for a family-based and a semi-specialized farm, and the consequences for system resilience of uptake of barley and manure application as a means of rotational forage production. After the disturbance profitability and one of the environmental performance indicators (soil organic matter) were negatively affected on both farms. The scope for recovery was larger for the SS farm than for the FB farm, as reflected in higher buffer and adaptive capacity. Improvements in profitability and organic matter balance would require considerable changes in the farm configurations, and thus flexibility in farm management. Resilience on both farms was found to be large but would require the farmers to have the managerial ability to make the required changes to move through the solution space.

In Chapter 6 the results of the study are summarized and discussed in relation to options for improving current farming system. The farms in the region were characterized by large dependence on external inputs, low internal nutrient efficiencies and large environmental externalities, suggesting that current dairy farming in the region is unsustainable. The small dairy farms seem to be caught in an intensification trap that results from the implementation of technological packages strongly resembling those of capital intensive system in North America. The explorations showed that simple rearrangement of existing farm resources may considerably improve current dairy farm performance across family-based on semi-specialized farm types. To actually implement these changes requires breaking away from current mainstream thinking about farming methods and considerable farming skills. In Chapter 6 implications for policy makers and farmers are discussed in setting priorities for stimulating sustainable intensification. 


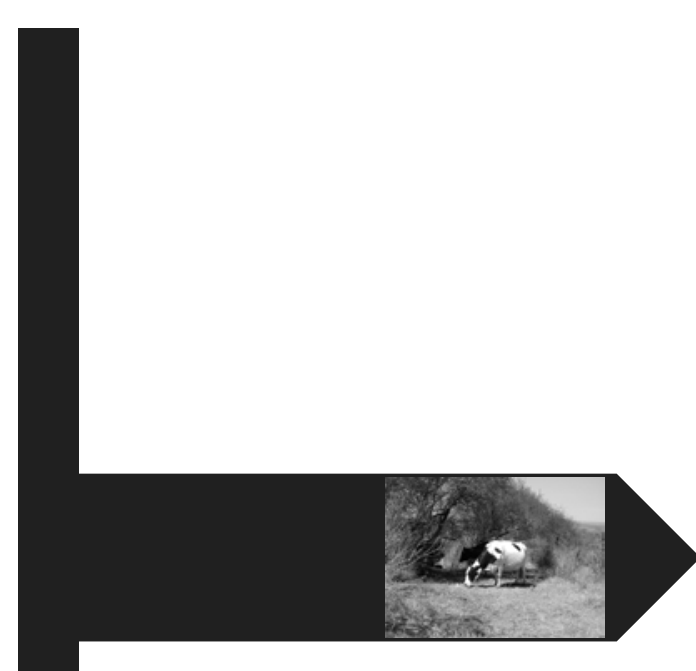

Acknowledgement

Curriculum Vitae

PE\&RC Training and Education Statement 



\section{Acknowledgments}

This thesis is result of the work of many people; some of them worked directly on it, and others influenced indirectly. Nevertheless, without the participation of all of them, the relevance of the results obtained would not been the same. Therefore, I want to thank to everyone similarly.

I will start mentioning to the dairy farmers of Marcos Castellanos, Michoacán, specially Arturo Padilla, Daniel Chávez, Everardo Haro, Filiberto García, Honorato González, and José Luis Orozco for their kind cooperation and willingness of being part of this project. These dairy farmers opened the doors of their farms to us in order to get everything what we needed for almost three years. That is why I am in debt with them, and I would like that the analysis presented in this thesis help them to improve their lives.

During the field work, the members of the Mexican EULACIAS team played an important role and always worked focused to reach the same aims. Part of that effort is reflected in this thesis. In this case, I want to thank Ricardo D. Améndola and D. Valentina Mariscal, for being the leaders that the project needed, and Luis Humberto Valencia, Efrén Trujillo, and Isela J. López, for their collaboration and hard field work to gather and organize the information.

My gratitude goes to my supervision team: Walter A. H. Rossing, Ricardo D. Améndola Massiotti, Johannes M. S. Scholberg, Pablo Tittonell, and Jeroen C. J. Groot. They were a very well balance team for my supervision, and everyone taught me and helped me during my PhD programme as they could. Additionally, Johannes always found the correct words to balance my frustrations and fall of spirit. Walter supported me and gave me advice to improve the quality of the thesis, and was the leader that made the team work together. And, Ricardo has always been teaching me and supporting me in my professional life; since my bachelor, Master programme, and in this study. I have no words to express all my thankfulness to him.

In the Farming Systems Ecology Group, I met many people that helped to create a good atmosphere in my surroundings. I really appreciated those moments and chats during lunch time and breaks, and soccer matches with Bas, Uma, Florencia, Joao Luiz Lani, his wife Mara Fernandes, Mustafa, Abbas, Muhammad, and Conny; so thanks for being part and sharing those moments. I am also grateful to Wampie, secretary of the group, for all her help and attention for all the administrative procedures, from the beginning until the end of this work.

Finally, I want to express my gratitude to my parents, sisters, brothers, nieces, and nephews for showing me they cared and for supporting me in good and bad times. Unfortunately, my father could not see the conclusion of this work, since he passed away before it was finished. They were the incentive that pushed me to conclude what I started many years ago. 


\section{Curriculum vitae}

José Cortez Arriola was born on 14 December 1965 in Guerrero, Mexico. He studied Animal Husbandry at Chapingo University, Mexico, where he graduated as agronomy engineer in 1995. In January 1996, he joined the Programme on forage production of the Animal Science Master of Science Programme at Chapingo University, from which he graduated in January 1998. In his Master thesis he studied grazing time, milk production and net herbage production in a system that included perennial and annual mixed pastures, under the supervision of Dr. Ricardo D. Améndola Massiotti. He graduated with honours and his thesis was awarded as the best M. Sc. thesis in applied biological sciences of Chapingo University in 1998. From February 1998 to August 2001, he worked as technical coordinator in a program to train smallholder livestock farmers in Yucatán, Mexico. His role was to organize courses, to coordinate the activities of the technicians, and to advise farmers on their farms. In September 2001, he joined the Mexican Ministry of Environment and Natural Resources as technician to assess environmental impacts. Until June 2007 he was in charge of evaluating environmental impacts of projects on forestry, agriculture, land use change, and development of tourism. In July 2007, he started a "sandwich” PhD Programme within the former Biological Farming Systems Group, currently Farming Systems Ecology Group of Wageningen University, sponsored by the European Union Project EULACIAS. At present, he is working as an environmental supervisor, and he is in charge of coordinating teams of technicians monitoring the environmental performance of large construction projects. 


\section{PE\&RC Training and Education Statement}

With the training and education activities listed below the PhD candidate has complied with the requirements set by the C.T. de Wit Graduate School for Production Ecology and Resource Conservation (PE\&RC) which comprises of a minimum total of 32 ECTS ( $=22$ weeks of activities)

\section{Review of literature ( 6 ECTS)}

- System approaches on alternative dairy family systems, with application to the Northwestern region of Michoacán, Mexico

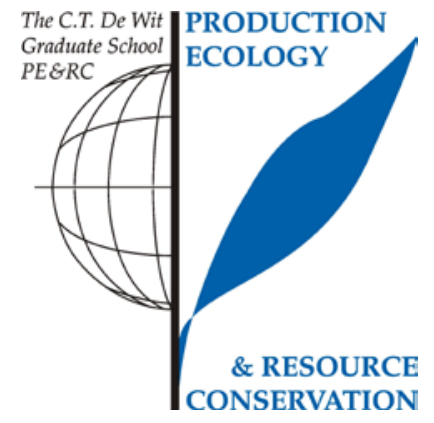

\section{Writing of project proposal (4.5 ECTS)}

- Profitability, resource use efficiency, and environmental impacts of traditional and alternative dairy production system in Northwest Michoacán, Mexico

\section{Post-graduate courses (2.7 ECTS)}

- Reflexion workshops for analysing the state of the project and defining alternatives of solution; EULACIAS (2010)

- Introduction to R for statistical; PE\&RC (2011)

- Sampling in space and time; PE\&RC (2012)

\section{Laboratory training and working visits ( 1.5 ECTS)}

- Soil taxonomy and classification; Colegio de Posgraduados, Mexico (2009)

\section{Invited review of (unpublished) journal manuscript ( 1 ECTS)}

- Agricultural Systems: social and income trade-offs of conservation agriculture practices on crop residue use in Mexico's central highlands (2014)

\section{Deficiency, refresh, brush-up courses (1.5 ECTS)}

- Basic statistics; PE\&RC (2012)

\section{Competence strengthening / skills courses (3.5 ECTS)}

Scientific writing; WGS (2011)

- Academic writing; WGS (2011)

\section{PE\&RC Annual meetings, seminars and the PE\&RC weekend ( 1.5 ECTS)}

- Introduction to participatory socio-environmental games and simulations; PE\&RC (2011)

- Innovation for sustainability what are the neighbours doing?; PE\&RC (2011)

- Weekend last year; PE\&RC (2011)

Discussion groups / local seminars / other scientific meetings (5.2 ECTS)

- EULACIAS Meeting (2008)

- Stakeholder participation in research; Chapingo University, Mexico (2008-2010)

\section{International symposia, workshops and conferences (2.6 ECTS)}

- ler Congreso Latinoamericano y Europeo en Co-innovation de Sistemas Sostenibles de Sustento Rural; Minas, Uruguay (2010)

- I Congreso Internacional de Manejo de Patizales; Chiapas, Mexico (2010)

\section{Lecturing / supervision of practical's / tutorials ( 1.5 ECTS)}

- Multidia course; Chapingo University, Mexico (2010)

\section{Supervision of MSc students ( 6 ECTS)}

- Alba Castañeda Vera: use of modelling approaches for characterization, design and analysis of traditional dairy farm systems

- Eline Boele: monitoring and modelling above ground biomass production of forage maize (Zea Mays) 
Cover: Grazing cows at Marcos Castellanos, Michoacán, México, painted by Mara Fernandes. 